UNIVERSIDADE DE SÃO PAULO

INSTITUTO DE GEOCIENCIAS

\title{
MACROFITOFÓSSEIS EM TUFOS CALCÁRIOS QUATERNÁRIOS DO NORTE DA BAHIA COMO INDICADORES PALEOCLIMÁTICOS
}

\author{
Patricia de Souza Cristalli
}

Orientador: Prof. Dr. Setembrino Petri

\section{TESE DE DOUTORAMENTO}

Programa de Pós-Graduação em Geologia Sedimentar

SÃO PAULO

2006 


\title{
MACROFITOFÓSSEIS EM TUFOS CALCÁRIOS QUATERNÁRIOS DO NORTE DA BAHIA COMO INDICADORES PALEOCLIMÁTICOS
}

\author{
PATRICIA DE SOUZA CRISTALLI
}

Orientador: Prof. Dr. Setembrino Petri

TESE DE DOUTORAMENTO

COMISSÃO JULGADORA

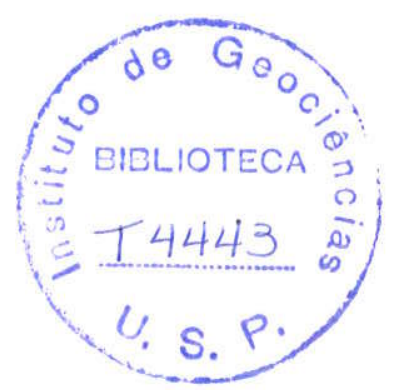

Nome

Assinatura

Presidente: Prof. Dr. Setembrino Petri

Examinadores: Prof. Dr. Gregório Cardoso Tápias Ceccantini

Prof. Dr. Ivo Karmann

Prof. Dr. Kenitiro Suguio

Prof ${ }^{a}$. Drạ. Tânia Lindner Dutra

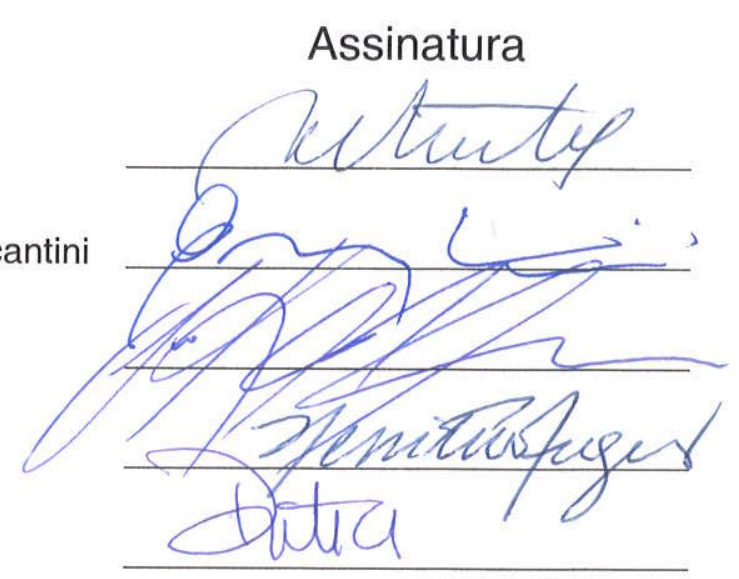

SÃO PAULO

2006 
UNIVERSIDADE DE SÃO PAULO

INSTITUTO DE GEOCIÊNCIAS

\section{MACROFITOFÓSSEIS EM TUFOS CALCÁRIOS QUATERNÁRIOS DO NORTE DA BAHIA COMO INDICADORES}

\section{PALEOCLIMÁTICOS}
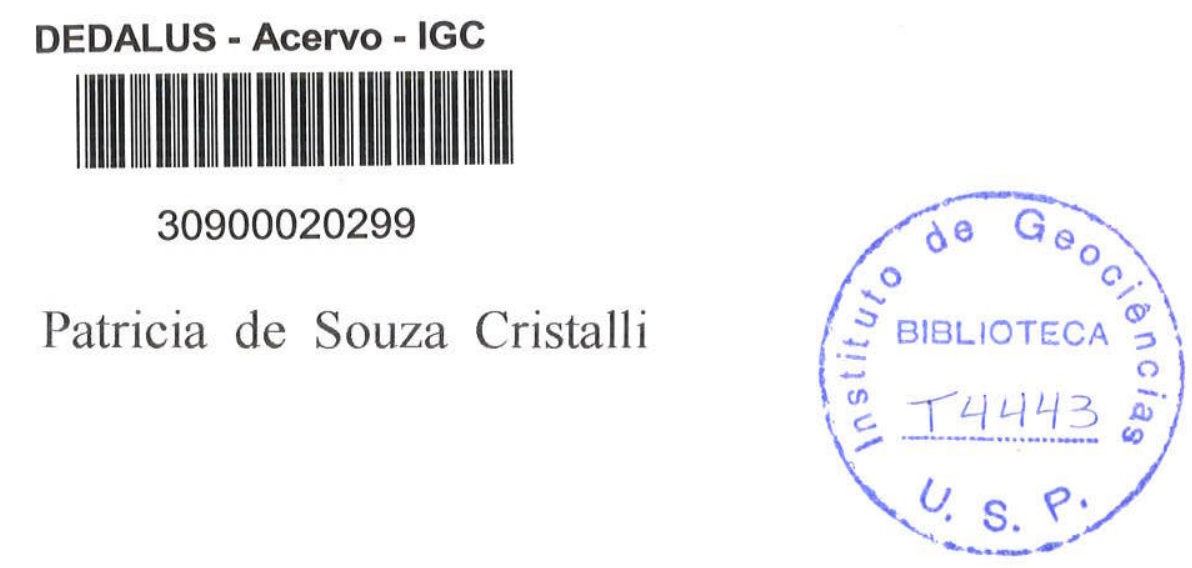

Orientador: Prof. Dr. SETEMBRINO PETRI

TESE DE DOUTORAMENTO

Programa de Pós-Graduação em Geologia Sedimentar

São Paulo

2006 
Agradecimentos

Agradeço ao querido Prof. Dr. Setembrino Petri por ter acreditado em mim e pela admirável dedicação na orientação desse trabalho, sempre fornecendo ótimos caminhos para a resolução de cada problema. Foi realmente uma grande honra ter-lo como orientador e amigo.

A FAPESP pelo apoio financeiro concedido a esta pesquisa e pelas boas sugestões do relator.

À Universidade de Mogi das Cruzes por ter me concedido espaço adequado para o meu trabalho (Laboratório de Ciências da Terra), participando também com recursos de infraestrutura e apoio aos mais de 20 alunos que, direta ou indiretamente, auxiliaram na obtenção dos dados desse trabalho. Assim, gostaria de destacar os alunos de Iniciação Cientifica Caroline Duran, Fernanda Lúcio Santos, Nathália Portero da Silva, Fernando Canova, Thaís Fernandes da Silva, Carolina Agostini Mittelstaedt, Gisele Utida, Fernanda Félix Ferreira, Paulo Henrique de Melo e Sílvia Andrade Imura.

Ao herbário ALCB tanto pelo contato inicial realizado pela professora Nádia Roque quanto pela total colaboração da curadora Maria Lenise Silva Guedes, que permitiu consulta e documentação fotográfica de todo material do herbário. Agradeço também a todos os alunos e funcionários presentes neste árduo processo. O trabalho neste herbário contou com a ajuda voluntária de Caroline Duran, sem a qual esse trabalho não poderia ter sido finalizado.

Ao herbário SPF pela pessoa do curador José Rubens Pirani que também permitiu acesso ao herbário incluindo documentação fotográfica.

Ao Prof. Dr. Vitor Fernandes Oliveira de Miranda, por todo o apoio nas discussões relacionadas a estrutura da vegetação e análise multivariada.

Ao Dr. Augusto Auler, UFMG, pela apresentação área de trabalho, ajuda nos trabalhos de campo, e por fornecer dados geocronológicos para amostras de tufas carbonáticas.

Aos professores Gregório Cardoso Tápias Ceccantini (IB-USP) e Kenitiro Suguio pelas sugestões durante o exame de qualificação.

Ao Prof. Dr. Ivo Karmann pelas discussões referentes à deposição dos tufos calcários.

Ao meu marido, Francisco William da Cruz Júnior, por participar ativamente dessa tese nos tópicos referentes a paleoclimatologia, revisão de texto, elaboração de figuras e trabalhos de campo.

À minha família pelo apoio nas mais diferentes circunstâncias, principalmente por entenderem o tempo abdicado a eles em pró dos trabalhos do doutorado.

E por fim, aos meus jovens amigos alunos por todo o apoio emocional fornecido no processo. 


\section{INDICE}

1 - Introdução e objetivos da pesquisa

2 - Aspectos gerais

2.1 - Caracterização da circulação atmosférica

2.2 - Caracterização da circulação oceânica com ênfase no Atlântico Sul

2.3 - Caracterização dos tipos climáticos da América do Sul

2.4 - Caracterização dos tipos vegetacionais presentes na América do Sul

3.1 - Localização geográfica e morfológica dos tufos calcários de Campo Formoso

3.2 - Aspectos geológicos

3.3 - Localização da área de tufos ativos em Bonito, MS

3.4 - Aspectos climatológicos atuais da região de Campo Formoso 30

3.5 - Aspectos ambientais que condicionam a distribuição da vegetação 31

4 - Métodos e técnicas

4.1 - Macrofitofósseis como indicadores paleoclimáticos

4.2 - Os tipos vegetacionais atuais da Bahia como parâmetros de comparação

4.3 - Descrição do material fossilifero e interpretações taxonômicas

4.4 - Análise fisionômica e suas interpretações

4.5 - Tufos ativos de Bonito, MS: mecanismos atuais de formação de tufos calcários

5.1 - Deposição de tufos calcários

5.2 - Aspectos tafonômicos associados a deposição vegetal

5.3 - Análise tafonômica dos depósitos de Campo Formoso, BA

6 - Resultados taxonômicos e suas interpretações

6.1 - Identificação taxonômica

6.2 - Composição florística da assembléia fóssil de Campo Formoso, BA

6.3 - Análise da distribuição das espécies registradas

6.4 - Comparações florísticas 
7.2 - Análises por tipo vegetacional

7.3 - Análises por caracteristicas

7.4 - Análises de vegetações e características acrescidas do caráter altitude

7.5 - Análises comparativas entre diferentes tipos de vegetações

7.6 - Interpretação geral da assembléia fóssil de Campo Formoso

8 - Discussões gerais

8.1 - Discussão das informações obtidas pelo estudo dos tufos calcários

8.2 - Discussão das informações obtidas pelo estudo taxonômico dos macrofitofósseis

8.3 - Discussão das informações obtidas pela análise fisionômica dos macrofitofósseis

8.4 - Discussão das informações obtidas referentes ao paleoclima 158

9 - Interpretações paleoclimáticas para a América do Sul na fase final da última glaciação

9.1 - Fenômenos climáticos no Hemisfério Sul

9.2 - Interpretação de fenômenos paleoclimáticos com ênfase nos periodos glaciais

9.3 - Caracterização da circulação no Oceano Atlântico no último período glacial

9.4 - Situação paleoclimática durante o último máximo glacial na América do Sul.

9.5 - Situação paleoclimática no Nordeste brasileiro e a importância da caatinga na compreensão de alguns fenômenos

10 - Considerações finais

11 - Referências bibliográficas 


\section{INDICE DE FIGURAS}

Figura 1 - Correntes atmosféricas na América do Sul durante o inveno e verão. $\quad 07$

Figura 2 - Mapa ilustrativo da América do Sul indicando os principais tipos vegetacionais. 13

Figura 3 - Município de Campo Formoso: hidrografia, localidades e municipios limítrofes. 24

Figura 4 - Perfil geológico de Campo Formoso, BA. 24

Figura 5 - Morfologia da porção distal dos três afloramentos de tufos calcários. 25

Figura 6 - Esquema em planta dos três afloramentos indicando os pontos de coleta 26

Figura 7 - Mapa de localização dos afloramentos e aspectos geológicos. 28

Figura 8 - Mapa de localização dos rios estudados na região de Bonito, MS 29

Figura 9 - Aspectos vegetacionais da Bahia.

Figura 10 - Mapa indicativo das diferentes ecorregiões do Bioma Caatinga. 37

Figura 11 - Representação das principais medidas lineares e angulares utilizadas. 41

Figura 12 - Representação gráfica do processo de planimetria por contagem de pontos. 41

Figura 13 - Quedas d'água do Rio Formoso com fluxo forte e vegetação lenhosa adjacente 48

Figura 14 - Padrões típicos de degradação foliar.

Figura 15 - Amostra 15-1 evidenciando canalículos e deposição de carbonato laminado. $\quad 54$

Figura 16 - Amostra 18-4 com depósito de calcita esparítica em faixas bem escuras e claras. 54

Figura 17 - Amostra 23-9 com carbonato laminado associado à folha e aos canalículos. $\quad 54$

Figura 18 - Margem foliar com dentes bem desenvolvidos e margem com crenação. $\quad 66$

Figura 19 - Folha de limbo lobado e folha de base cordata com nervação actinódroma 70

Figura 20 - Ilustração do padrão pinado broquidódromo à esquerda e eucamptódromo à direita 72

$\begin{array}{ll}\text { Figura } 21 \text { - llustração de primeira interárea ampla } & 79\end{array}$

Figura 22 - Ilustração da nervação externa $\quad 79$

Figura 23 - Ilustração da nervação terciária percorrente $\quad 85$

Figura 24 - Ilustração de nervuras secundárias alternas entre si e opostas a intersecundárias. $\quad 88$

Figura 25 - Foto da amostra 18-5 mostrando dois espécimes do morfotipo 6 identificados 106

Figura 26 - Fotos das amostras 26-2 e 26-11 com espécimes do morfotipo 7 identificados 107

Figura 27 - Foto da amostra 14-1 com o espécime do morfotipo 9B identificado 108

Figura 28 - Fotos das amostras 19-3 e 18-6 com espécimes do morfotipo 13A identificado 109

Figura 29 - Foto da amostra 16-3 como espécime do morfotipo 14B identificado 110 
Figura 30 - Foto da amostra 10-2 com o espécime do morfotipo 14E identificado

Figura 31 - Foto da amostra 14-4 com dois espécimes não identificados

Figura 32 - Foto da amostra 22-2 com o espécime do morfotipo $15 \mathrm{~A}$ identificado

Figura 33 - Foto da amostra 22-3 com espécime do morfotipo 10 identificado e foto da amostra 20-4 representativo do morfotipo $15 \mathrm{C}$.

Figura 34 - Mapa da Bahia indicando os municípios estudados na análise fisionômica

Figura 35 - Precipitação sazonal total na América do Sul

Figura 36 - Posição da ITCZ atual e seu possível deslocamento durante os eventos Heinrich. 170

Figura 37 - Mapa paleoclimático da América do Sul há 22.000 anos não calibrado

Figura 38 - Mapa paleoclimático da América do Sul há 20.000 anos não calibrado

Figura 39 - Mapa paleoclimático da América do Sul há 18.000 anos (21.500 anos calibrado)

Figura 40 - Mapa paleoclimático da América do Sul há 16.000 anos (19.500 anos calibrado) 174

Figura 41 - Mapa paleoclimático da América do Sul há 14.000 anos (17.000 anos calibrado) 175

Figura 42 - Mapa paleoclimático da América do Sul há 12.000 anos (14.000 anos calibrado) 176

Figura 43 - Mapa paleoclimático da América do Sul há 10.000 anos (11.500 anos calibrados) 177

Figura 44 Mapa paleoclimático da América do Sul há 8.000 anos (9.000 anos calibrados) 178 
Tabela 1 - Siglas utilizadas neste trabalho 01

Tabela 2 - Análise quantitativa das feições tafonômicas foliares em cada ponto de coleta.

Tabela 3 - Atributos tafonômicos I dos Afloramentos Salgadinho, Fazenda Bento e Pacuí. $57 / 58$

Tabela 4 - Atributos tafonômicos Il dos Afloramentos Salgadinho, Fazenda Bento e Pacuí. $\quad 58 / 59$

Tabela 5 - Atributos tafonômicos III dos Afloramentos Salgadinho, Fazenda Bento e Pacui 60

Tabela 6 - Relação das espécies identificadas aos morfotipos descritos em Campo Formoso $94 / 96$

Tabela 7 - Relação das espécies comparadas aos morfotipos mas que foram rejeitadas $\quad 97 / 98$

Tabela 8 - Síntese das localidades e vegetações nas quais as espécies utilizadas na comparação com os morfotipos de Campo Formoso estavam presentes

Tábela 9 (A e B) - Número de gêneros e espécies de cada característica analisada.

Tabela 11 - Síntese das características fisionômicas das vegetações de cerrado, caatinga e floresta estacional na Bahia.

Tabela 12 - "Localidades" próximas a Campo Formoso em pelo menos três eixos das diferentes PCAs realizadas

Tabela 13 - Síntese dos principais dados sobre os eventos oceânicos durante a última glaciação e a transição para o pós-glacial. 


\section{INDICE DE GRÁFICOS}

Gráfico 1 - Análise global: PCA de 144 "localidades" para comparação com a assembléia fóssil de Campo formoso. Eixos 1 e 2.

Gráfico 2 - Análise da vegetação de Caatinga e regiões de contato: PCA de 39 "localidades" para comparação com a assembléia fóssil de Campo Formoso. Eixos 1 e 2.

Gráfico 3 - Análise da vegetação de floresta estacional e regiões de contato: PCA de 34 "localidades" para comparação com a assembléia fóssil de Campo Formoso. Eixos 1 e 2 .

Gráfico 4 - Análise da vegetação de floresta estacional e regiões de contato: PCA de 34 "localidades" para comparação com a assembléia fóssil de Campo Formoso. Eixos 1 e 3.

Gráfico 5 - Tipos de margem foliar e classes de tamanho: PCA de 72 "localidades" para comparação com a assembléia fóssil de Campo Formoso. Eixos 1 e 2 .

Gráfico 6 - Forma foliar e tipos de ápice e de base: PCA de 72 "localidades" para comparação com a assembléia fóssil de Campo Formoso. Eixos 1 e 2.

Gráfico 7 - Análise das vegetações de caatinga e mata ciliar. PCA de 52 "localidades" para comparação com a assembléia fóssil de Campo Formoso. Eixos 1 e 3.

Gráfico 8 - Análise das vegetações de caatinga e cerrado. PCA de 46 "localidades" em comparação com a assembléia fóssil de Campo Formoso. Eixos 1 e 2. 


\section{Resumo}

Estudo de folhas fósseis preservadas nos tufos calcários, datados pela série de desequilibro do urânio, objeto do presente trabalho, permitiram investigar mudanças da vegetação e do clima ocorridas entre 21.000 e 9.000 anos atrás ao longo do vale do rio Salitre, no município de Campo Formoso, norte da Bahia, área atualmente com típica ocorrência de caatinga e clima semi-árido.

Foram descritos 69 morfotipos, tendo sido identificadas 49 através de estudos comparativos com material do herbário ALCB, da Universidade Federal da Bahia e estudos complementares efetuados no herbário SPF, da Universidade de São Paulo. Estão presentes cinco espécies de Annonaceae e Euphorbiaceae, quatro espécies de Malvaceae e Lamiaceae, três de Begoniaceae, duas espécies de Bignoniaceae, Chrysobalanaceae, Elaeocarpaceae, Malpighiaceae e Sterculiaceae, além de uma espécie de Apocynaceae, Aquifoliaceae, Boraginaceae, Campanulaceae, Cecropiaceae, Celastraceae, Connaraceae, Dilleniaceae, Clusiaceae, Olacaceae, Phytolacaceae, Piperaceae, Rhamnaceae, Rosaceae, Rutaceae e Tiliaceae, sendo considerada uma assembléia bem diversificada.

A análise fisionômica das folhas fósseis, diferentemente de outras análises fisionômicas publicadas que utilizam padrões fisionômicos mundiais, teve como base uma comparação dos padrões fisionômicos estabelecidos a partir de exemplares representativos de toda vegetação atualmente presente no Estado da Bahia. Ambas análises, sistemática e fisionômica das folhas, resultaram no reconhecimento de mistura de vegetações no passado, caracterizada pela presença de elementos da caatinga, cerrado e das florestas estacionais. Espécies das duas últimas vegetações tiveram suas origem associadas à migração de coberturas, hoje localizadas no oeste baiano e nas porções mais elevadas da Chapada Diamantina, respectivamente. As duas análises, em conjunto, permitiram inferir vegetação de dossel fechado e representativo de clima mais chuvoso do que o clima atual.

A análise tafonômica do depósito sugere distribuição mais uniforme das chuvas ao longo do ano, podendo refletir em clima com menor duração da estação seca. Foi possivel estabelecer dois subambientes deposicionais assim como condições transicionais entre ambos, reconhecendo feições indicativas de fluxo turbulento de água e feições indicativas de fluxo pouco turbulento. A análise tafonômica só foi possivel através do estudo comparativo realizado com os depósitos de tufos calcários atuais na região de Bonito, MS.

Não há indicações de corredores entre as vegetações atlântica e amazônica como sugerido em alguns trabalhos prévios 
Fossil of leaves preserved in carbonate tufas and dated by U-series method are studied in order to investigate the vegetacional and climate changes occurred between 21,000 and 9,000 years ago over Rio Salitre valley, a semi-arid area today covered by caatinga vegetation and located in the Campo Formoso municipality, northern Bahia.

Analysis of vegetal remains has allowed description of 69 morphotypes and the identification of 49 plants species through comparison with the ALCB herbarium documentation of the University Federal of Bahia and complementary studies with the SPF herbarium documentation of the University of São Paulo. The systematic analysis detected the presence of five species of Annonaceae and Euphorbiaceae, four species of Malvaceae and Lamiaceae, three species of Begoniaceae, two species of Bignoniaceae, Chrysobalanaceae, Elaeocarpaceae, Malpighiaceae and Sterculiaceae, beyond one species of Apocynaceae, Aquifoliaceae, Boraginaceae, Campanulaceae, Cecropiaceae, Celastraceae, Connaraceae, Dilleniaceae, Guttiferae (=Clusiaceae), Olacaceae, Phytolacaceae, Piperaceae, Rhamnaceae, Rosaceae, Rutaceae and Tiliaceae. This can be considered a quite diversified fossil assemblage.

Climate parameters as humidity and temperature play an important role in the photosynthetic process that control the morphology of the leaves, allowing them to be used as paleoenvironmental and paleoclimatic proxies. The multivariate physiognomic analysis of fossils of leaves was possible after establishment of modern physiognomic pattern of vegetation based on samples of ALCB herbarium representative of Bahia state.

Both systematic and physiognomic analysis points out mixed paleovegetation characterized by the presence of elements from caatinga, cerrado and seasonal submontane forests. The last two elements probably migrated from western Bahia and also from high elevations in surrounding Chapada Diamantina, respectively. These results provide evidence for the presence of closer forests that reflect a better distributed rainfall during transition from Last Glacial Maximum and Holocene than observed today in the study area. This inference is additionally supported by taphonomic analysis on studied samples of fossil tufas that were compared to active deposits from Bonito region, Mato Grosso do Sul. 


\section{1 - Introdução e objetivos da pesquisa}

Ao longo do texto serão utilizadas diversas siglas que serão sintetizadas no quadro a seguir visando facilitar a leitura do mesmo.

\begin{tabular}{|c|c|}
\hline $\mathrm{AGCM}$ & Atmosphere General Circulation Model \\
\hline ALCB & Herbário da Universidade Federal da Bahia \\
\hline CLIMAP & Climate Long range Investigation and MAPping \\
\hline DSDP & Deep Sea Drilling Project \\
\hline EMBASA & EMpresa Baiana de Aguas e SAneamento \\
\hline ENSO & El Niño - Oscilação Sul \\
\hline $\mathrm{IBGE}$ & Instituto Brasileiro de Geografia e Estatística \\
\hline ITCZ & Zona de Convergência Inter Tropical \\
\hline PCA & Análise dos componentes principais \\
\hline SEI & $\begin{array}{l}\text { Superintendência de Estudos Econômicos e Sociais } \\
\text { da Bahia (www.sei.ba.gov.br) }\end{array}$ \\
\hline $\mathrm{SO}$ & Oscilação Sul \\
\hline $\mathrm{SACZ}$ & Zona de Convergência do Atlântico Sul \\
\hline SAMS & Sistema de Monções Sul-Americano \\
\hline SPCZ & Zona de Convergência do Pacífico Sul \\
\hline $\mathrm{SPF}$ & Herbário da Universidade de São Paulo \\
\hline
\end{tabular}

Tabela 1 - Siglas utilizadas neste trabalho. 
Introdução

Os estudos do Quatemário são capazes de estabelecer um elo de ligação entre o passado geológico pouco remoto e o presente. Em situações favoráveis podem estabelecer prognósticos futuros (Suguio, 1999). Entretanto, muitos dados disponiveis para estudos são temporalmente descontínuos, exceto as amostras de gelo e de sedimentos oceânicos profundos, prejudicando as interpretaçò̀es.

Na América do Sul, os registros climáticos estudados são mais numerosos na região dos Andes, sendo utilizados como dados complementares à compreensão e datação do último soerguimento da cordilheira, que teria ocorrido há cerca de 2,5 a 3 milhões de anos (Mörner, 1993) Os dados são muito esparsos nas áreas baixas, onde se encontra a maior biodiversidade do mundo. A partir dos anos noventa o número de trabalhos com ênfases paleoclimáticas vem aumentando.

Para prever o efeito da ação do Homem em relação ao meio ambiente é necessário conhecer como se desenvolveu em termos paleoambientais essa enorme fonte de biodiversidade. Torna-se necessário saber também quais fatores climáticos são os mais prejudiciais à biodiversidade e quão rápidas são as respostas biológicas em função das diferentes mudanças climáticas e ambientais Conhecer o passado ainda é o melhor caminho de se prever o futuro. Este fato é da maior importância porque o desenvolvimento econômico e suas conseqüências têm andado mais rápido que os avanços técnico-cientificos e talvez, por isso, ainda tenhamos a oportunidade de conhecer melhor o passado da América do Sul.

Sabe-se que a Terra enfrentou e provavelmente enfrentará uma série de mudanças climáticas de curtas e longas durações, com profundos efeitos nos processos geomorfológicos e biológicos. Essa ciclicidade permite que conheçamos os processos e os mecanismos que operam essas mudanças, de modo que possamos predizer as possíveis respostas desse complexo Sistema Terra à intervenção humana, mas para isso é necessário um conjunto maior de dados relacionados ao Quaternário e especialmente ao último evento glacial.

Essa necessidade originou grandes projetos internacionais como o DSDP e o CLIMAP, assim como alguns outros.

A América do Sul representa um bom continente para estudos climáticos, dada a grande sazonalidade do clima no hemisfério sul e sua ampla variação latitudinal: de $12^{\circ} \mathrm{N}$ a $56^{\circ} \mathrm{S}$.

As oscilações na temperatura e na umidade indicam que o clima não foi estável após a última deglaciação. Essas alterações climáticas também são registradas nas terras baixas tropicais e quentes do Brasil Central (Salgado-Labouriau et al., 1997). 
Objetivos da pesquisa

A presente pesquisa visa o estudo da variação climática e vegetacional na região do norte da Bahia, entre 25.000 e 8.000 anos atrás, tendo como base o estudo de tufeiras ricamente fossiliferas. A caracterização de seu conteúdo, basicamente composto de folhas, permite a inferência do tipo de vegetação e de suas características evolutivas com respeito às mudanças climáticas ocorridas desde o último máximo glacial.

Constitui - se nos seguintes objetivos especificos:

1) Descrever os diferentes tipos de folhas de modo a caracterizar o registro fossilifero. Esse trabalho serve de base para as diferentes interpretações dos depósitos;

2) Obter os parâmetros morfométricos necessários à interpretação paleoclimática;

3) Inferir os dados pretéritos referentes ao clima e à estrutura da vegetação. Seja por análise multivariada dos parâmetros morfométrico, seja por estudos florísticos;

4) Correlacionar os dados paleoclimáticos obtidos com os demais tipos de registros paleoclimáticos brasileiros na mesma faixa de idade;

5) Efetuar comparações entre a vegetação pretérita e a atual na região, de modo a complementar os estudos referentes a origem e desenvolvimento da caatinga.

6) Descrever tafonomicamente o depósito, obtendo-se mais informações sobre a paleogeografia da região no tocante a localização e direção da drenagem. 


\section{2 - Aspectos gerais}

Para adequada interpretaçào paleoclimática faz-se necessärio conhecer os aspectos gerais relacionados ao clima e à vegetaçăo atuais, esta última utilizada na interpretaçào de climas pretéritos. Os parâmetros climáticos são afetados pelos padrões de circulação atmosférica e pelos padrões de circulação marinha, de modo que ao tentar interpretar como esses parâmetros se alteram durante o Quaternário, os dados provenientes do oeste da África poderiam ser úteis no entendimento das mudanças climáticas que afetaram o continente sul-americano, mas não foram obtidas as correlações esperadas, visto que a distribuição da vegetação na África é muito diferenciada e as mudanças climáticas não puderam ser comparadas.

Ao longo deste trabalho serăo apresentados dados referentes ao Oceano Atlântico e dados referentes a toda a América do Sul. A seqüência de apresentação de dados na América do Sul tem como objetivo focalizar melhor a atenção para a área em estudo, de modo que se inicia no sul da América do Sul, seguindo a Cordilheira dos Andes até a região amazônica. A partir da Amazônia, enfoca-se mais detalhadamente aspectos brasileiros, de norte para sudeste, concluindo com a região nordeste, área em estudo.

\section{1 - Caracterização da circulação atmosférica}

Todas as massas de ar responsáveis pelas condições climáticas na América do Sul atuam no Brasil direta ou indiretamente. Entre elas tem-se a Equatorial Atlântica, a Equatorial Continental, a Equatorial Pacífica, a Equatorial Norte, a Tropical Atlântica, a Tropical Continental, a Tropical Pacífica, a Antártica, a Polar Antártica, a Polar Pacifica e a massa de ar Superior (Nimer, 1989).

As massas de ar equatoriais, três marítimas e uma continental, são originadas de determinadas regiões dos ventos alísios. A massa de ar Equatorial Atlântica, origina-se da zona dos alísios de sudeste do anticiclone do Atlântico Sul, da mesma forma que os alísios de sudeste do anticiclone do Pacífico Sul origina a massa de ar Equatorial Pacífica. Os alísios de nordeste do anticiclone do Atlântico Norte originam a massa de ar Equatorial Norte. São separadas pelo continente e pelas calmarias equatoriais. As três apresentam subsidência e inversão térmica que dificulta a mistura, resultando em estabilidade. Entretanto, nos limites da massa de ar Equatorial Atlântica, a descontinuidade térmica se enfraquece, tornando-se instável, o que causa fortes chuvas equatoriais. A massa de ar Equatorial continental forma-se principalmente na zona do cerrado onde domina o regime depressionário continental, sobretudo no verão. O continente torna-se um centro quente para o qual afluem os ventos oceânicos de norte e leste, oriundos da massa Equatorial norte. 
Por produzir acentuada ascensão, possuem instabilidade conectiva e provoca precipitações abundantes

As massas tropicais de ar originam-se de zona de ventos variáveis e divergentes das calmarias subtropicais, ou seja, dos anticiclones semifixos do Atlântico e do Pacífico, limitando-se ao norte pelos alisios de sudeste e ao sul pelas massas polares. A massa de ar Tropical Pacífica não chega a afetar o Brasil diretamente. A massa de ar Tropical Atlântica forma-se na região maritima quente do Atlàntico Sul, recebendo muito calor e umidade. Torna-se instável no verão, quando sofre grande aquecimento na costa da América do Sul. A massa de ar Tropical Continental também adquire maior importância durante o verão, mais especificamente do final da primavera ao inicio do outono. Origina-se na zona baixa estreita a leste dos Andes, região quente e árida, de modo que a depressão térmica do Chaco representa a fonte dessa massa de ar (Nimer, 1989).

As regiões tropicais do Brasil, com exceção do oeste da Amazônia, apresentam ventos oriundos do quadrante leste durante todo o ano. Esses ventos originam-se nas altas pressões subtropicais e é denominado anticiclone semifixo do Atlântico Sul e sua umidade é limitada à camada de ar superficial, sendo de caráter homogêneo e estável. Durante quase todo o ano esse sistema transporta massas tropicais úmidas para o continente de noroeste a nordeste. A estabilidade do anticiclone só cessa com a chegada de correntes perturbadoras. Essas correntes são responsáveis pelas instabilidades e chuvas na região nordeste do país. Há quatro sistemas perturbadores sul, norte, leste e oeste (Nimer, 1989).

As correntes perturbadoras de sul estão representadas por invasões de frentes polares que raramente conseguem ultrapassar a latitude de $15^{\circ} \mathrm{S}$ durante primavera e verão, quando provoca chuvas frontais e pós-frontais ao longo do litoral até o sul da Bahia. No inverno, pode atingir o litoral pernambucano, enquanto o sertão permanece sob ação de alta tropical com tempo estável.

As correntes perturbadoras de norte são representadas pelo deslocamento da zona de convergência intertropical (ITCZ), oriunda da convergência dos alísios dos dois hemisférios. Governado pelas forças coriolanas, o ar desloca-se da área de alta pressão subtropical no hemisfério sul, para a zona de baixa pressão equatorial, divergindo para oeste. Neste processo origina-se os ventos de sudeste. A fronteira norte dos ventos de sudeste é formada pela ITCZ, zona de origem do ar úmido do equador vindo do norte (Höll et al., 2000). Ao longo desta depressão equatorial geralmente conhecida por região de calmarias, o ar em ascendência provoca chuvas e trovoadas geralmente muito intensas. Durante o inverno do hemisfério sul, a área de alta pressão subtropical está fortemente desenvolvida e situa-se bem mais a noroeste que durante o verão austral. Como resultado, os ventos de sudeste são intensificados e a ITCZ desloca-se para o norte. No verão 
austral, ocorre o inverso. Nos deslocamentos para o sul, chega a provocar chuvas até nas latitudes 9 a $10^{\circ} \mathrm{S}$, ou seja, nas imediações do Raso da Catarina, "cotovelo" do rio Săo Francisco.

No sistema leste pode ocorrer variaçoes do próprio anticiclone tropical, que apresenta inversão térmica superior. Essa inversão divide os alisios em duas camadas, uma inferior fresca e úmida e outra superior quente e seca. Quanto mais baixa a altitude dessa inversão, mais estável é o tempo. No litoral do nordeste esta inversão é mais alta, desaparecendo no contato com a frente polar ao sul e a $1 \mathrm{TCZ}$ ao norte. Entretanto, essa inversão pode desaparecer em função de ventos denominados ondas de leste e de linhas de instabilidades tropicais. Como essas perturbaçōes ocorrem no seio dos anticiclones tropicais, são consideradas pseudofrentes, que faz com que desapareça a inversão térmica ocasionando a mistura das duas camadas de ar e conseqüentemente, chuvas. Tal fenomeno pode ocorrer do Rio Grande do Norte ao norte do Rio de Janeiro, sendo mais freqüente na Zona da Mata pernambucana e na zona cacaueira da Bahia (Nimer, 1989).

No sistema oeste, as linhas de instabilidades tropicais entre o final da primavera e o início do outono, geralmente acarretam chuvas e trovoadas, fenômenos comuns no interior do Brasil especialmente no verão. As instabilidades tropicais que atingem o nordeste são formadas, na maioria das vezes, sobre os estados do Pará e Goiás, deslocando-se para leste. É importante salientar que a freqüência dessas instabilidades é bem menor no nordeste que no interior da Amazònia e nas regiões sudeste e centro-oeste do país (Nimer, 1989).

As estações do ano que são bem marcadas em médias latitudes, tornam-se cada vez menos nítidas a medida que se aproxima do equador, região submetida à forte radiação solar. As temperaturas médias anuais são mais elevadas nas regiões próximas ao equador, que tendem a apresentar média entre 26 e $28^{\circ} \mathrm{C}$. O notdeste brasileiro não é exceção, embora a influência moderadora dos alísios faça com que a região litorânea oriental seja menos quente com médias variando de 24 a $26^{\circ} \mathrm{C}$ (Nimer, 1989).

Em relação a precipitação, pode-se resumidamente explanar que no sul e no noroeste do Brasil, as chuvas são quase uniformemente distribuídas ao longo do ano. Na grande área central do Brasil, a porcentagem de chuvas entre dezembro e fevereiro corresponde a $45 \%$ ou mais, que juntamente com o período de setembro a novembro, pode representar mais de $70 \%$ das chuvas. Porém, no nordeste propriamente dito, o periodo de chuvas concentra-se de março a maio, com mais de $40 \%$ da precipitação, que juntamente com o período de dezembro a fevereiro, totalizam mais de $80 \%$ das chuvas (Rao el al., 1996). 


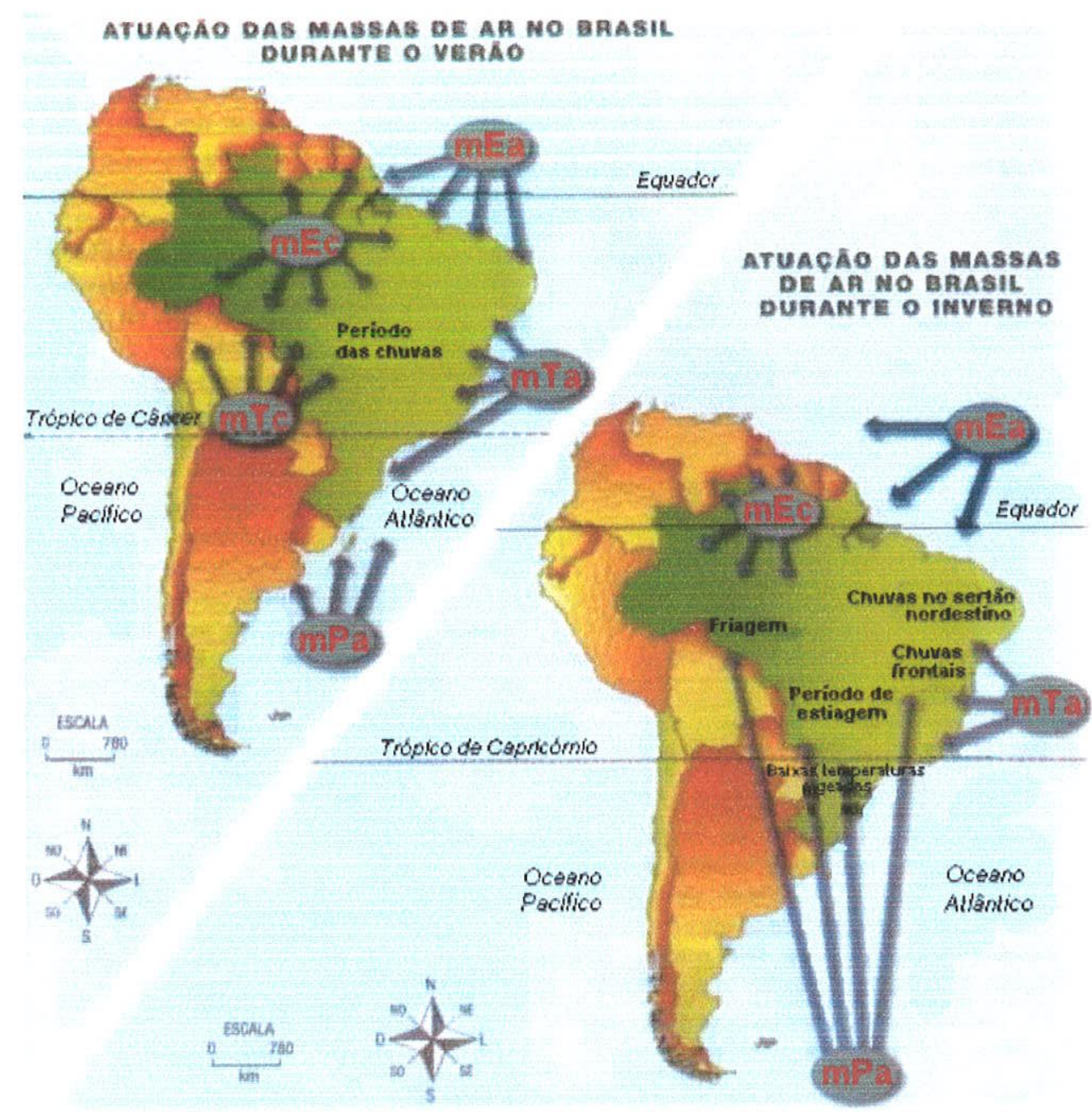

Figura 1 - Correntes atmosféricas na América do Sul durante o inverno e verão, especialmente no Brasil. Legenda: $\mathrm{mPa}$ - massa de ar polar; $\mathrm{mTa}$ - massa tropical atlântica; mEc - massa equatorial continental; $\mathrm{mEa}$ - massa equatorial atlântica; $\mathrm{mTc}$ - massa tropical continental.

A convergência subtropical possui posição variável sazonalmente em vários graus de latitude, enquanto que a frente polar antártica permanece aproximadamente dentro dos mesmos limites ao longo do ano. Ao sul da convergência prevalecem os ventos de oeste (Morley, 1979).

Uma das mais importantes feições atmosféricas durante o verão da América do Sul corresponde a Zona de Convergência do Atlântico Sul (SACZ), uma intensa convecção no subtrópico próximo ao litoral projetando-se para o Atlântico Sul. Esta região acumula valores máximos de precipitação e está conectada à região de mais intensa convecção sobre a Bacia Amazônica. No sudeste a precipitação relacionada a SACZ ocorre principalmente no verão e no norte principalmente ao redor de julho (Rao et al., 1996). 
O Oceano Atlântico tropical é área de especial interesse por cobrir a região de troca de calor entre os hemisférios sul e norte como parte do sistema de circulação global.

A convergência subtropical divide o atlântico sul em dois padrões de circulação distintos. Ao sul da convergència prevalecem os ventos de oeste, que direcionam a corrente circumpolar antártica em sentido horário (Morley, 1979).

As águas do Atlântico Sul central, que se dirigem ao norte em direção ao equador, são formadas pelas águas da convergência subtropical que afundam. O Atlântico Sul contém duas outras massas d'águas subsuperficiais: águas profundas do Atlântico Norte, presentes na coluna d'água aproximadamente entre 1.500 e 4.000 metros e as águas antárticas de fundo, que vão para o norte desde o continente antártico em profundidades maiores que 4.000 metros (Morley, 1979).

A área superficial ao norte da Convergência Subtropical, denomina-se Giro Subtropical e caracteriza-se pelo fluxo anti-horário da corrente que são guiadas pelos ventos sudestes. A corrente de Benguela dirige-se para o norte superficialmente pela costa africana e cria uma região de ressurgência na porção leste do Giro Subtropical. O sistema de correntes superficiais no Atlântico tropical é caracterizado por um grande fluxo para oeste pela corrente equatorial sul que se subdivide em dois ramos: um principal para o sul e outro menor e mais rápido para o norte, ambos são divididas pela corrente horária sul equatorial.

A corrente sul equatorial forma a parte norte do Giro Subtropical e encontra-se geralmente entre as latitudes $10^{\circ} \mathrm{S}$ e $3^{\circ} \mathrm{N}$. A divergência tropical é mais forte no Atlântico leste equatorial onde flui para o leste muito raso. A cerca de $10^{\circ} \mathrm{S}$ o ramo sul da corrente sul equatorial divide-se originando a corrente do Brasil para o sul e corrente norte do Brasil para o norte. A corrente do Brasil estende-se do equador a aproximadamente $35^{\circ} \mathrm{S}$ onde encontra a corrente das Malvinas que se dirige para norte (Morley, 1979). Estas correntes podem ser observadas na figura 36 (página 170)

A corrente submarina equatorial de direção leste origina-se no oeste do Atlântico equatorial fluindo ao longo do equador a cerca de 100 metros de profundidade para finalmente suprir as águas superficiais fora da costa africana.

Abaixo das águas superficiais mistas encontram-se as águas do sul do Atlântico central e abaixo dela as águas intermediárias antárticas entre 400 a cerca de 1.000-1.200 metros de profundidade seguindo para o norte. As águas profundas do Atlântico norte seguem para sul entre as águas intermediárias antárticas e as águas antárticas de fundo (Höll et al., 2000). 
A área da ITCZ mostra as maiores temperaturas superficiais no Oceano Atlântico. Durante o inverno do hemisfério sul, com os ventos sudestes intensificados e a ITCZ mais ao norte, a velocidade da corrente sul equatorial atinge o seu máximo, permitindo a divergência das águas superficiais bem misturadas e alta produtividade, como termóclina rasa, a cerca de 50 metros de profundidade e a menor temperatura superficial das águas no leste do Atlântico equatorial. A profundidade da termóclina na parte oeste origina condiçŏes oligotróficas.

Durante o verão austral, a área de alta pressão subtropical é menos intensa e situa-se mais ao sul, resultando em ventos sudestes fracos e velocidade minima da corrente sul equatorial. No leste a divergência é mínima resultando em águas relativamente estratificadas com menor bioprodutividade. A termóclina está relativamente baixa a cerca de 60 metros de profundidade e temperatura superficial do oceano atinge o seu máximo. A termóclina no oeste está mais rasa, mas continua mais profunda que no leste, mantendo condições oligotróficas nas águas superficiais. $O$ fluxo para leste da corrente submarina equatorial atinge o seu máximo.

A região equatorial do Atlântico é influenciada ainda pelo sistema de monções SW-NE da África tropical. No Atlântico equatorial os ventos sudestes no verão apresentam um componente meridional mais forte e um componente zonal mais fraco, diminuindo a velocidade da corrente sul equatorial, resultando na diminuição da intensidade da ressurgência equatorial.

\section{3 - Caracterização dos tipos climáticos da América do Sul}

O clima no sul dos Andes (Chile e Argentina) é altamente variado. Os picos mais altos na área mais ao norte bloqueiam a penetração das ondas úmidas de oeste vindas do Oceano Pacífico. Portanto, as encostas chilenas possuem clima sazonalmente quente e úmido enquanto que a Argentina experimenta condições áridas, na sombra de precipitação. Nesses termos, invernos são úmidos e verões secos, devido à flutuação sazonal das ondas de oeste e das frentes polares. Para o norte, no Chile, as chuvas de inverno vão gradualmente escasseando, enquanto que o norte da Argentina fica sob a influência das chuvas de verão causadas pelas massas de ar subtropicais úmidas, que sopram de sudoeste entre as zonas de alta pressão no Oceano Atlântico e os centros de baixa pressão nos continentes (Heusser, 1989). A precipitação média anual no lado oeste dos Andes excede 3.000 milímetros por ano mas declina rapidamente para leste, chegando a níveis inferiores a 600 milímetros por ano (Rabassa \& Clapperton, 1990).

Na planície do Chaco-Pampa o clima é subtropical com umidade no leste tendendo a árido no oeste e sudoeste. Condiçōes tropicais úmidas prevalecem na região nordeste. Esse padrão climático reflete a influência do Oceano Atlântico na América do Sul. O anticiclone sul-americano 
introduz ventos quentes e úmidos de norte e nordeste e o anticiclone do Pacifico Sul traz massas de ar frias e secas pelo sul. Extremos climáticos ocorrem durante o fenómeno El Niño, quando há grandes precipitações (lriondo \& Garcia, 1993). O cinturão frio temperado estende-se a $42^{\circ} \mathrm{S}$ enquanto que as ondas de oeste e a precipitação atingem seu máximo a cerca de $50^{\circ} \mathrm{S}$. A precipitação aumenta sazonalmente no norte da Argentina, com a maioria das chuvas no inverno, acompanhada de maior amplitude térmica diária (Hulton el al., 1994).

$\mathrm{O}$ clima entre 40 e 42 'S, na região oeste da América do Sul, é sazonal oscilando com as frentes polares e o anticiclone subtropical pacifico. A precipitação é freqüente principalmente no outono e inverno, quando a atividade anticiclonal é mais intensa. As temperaturas em janeiro variam em torno de $14-16^{\circ} \mathrm{C}$ e em julho entre 7 e $8^{\circ} \mathrm{C}$. A migração da frente polar no Quaternário aparentemente resulta em mudanças na circulação atmosférica que pode ser a explicação para as mudanças climáticas e vegetacionais observadas no registro polinico (Heusser, 1981).

O clima quente e seco com pronunciada estação seca no sul do Brasil (RS, SC, PR e SP) pode ser explicado pela forte influência das massas de ar continentais tropicais secas que bloqueiam o avanço das frentes polares (Behling, 1998).

O Altiplano propriamente dito, localizado entre as cordilheiras leste e oeste dos Andes, a cerca de 3.800 metros de altitude, exibe climas áridos a semi-áridos, com precipitação de 700 milímetros por ano ao norte, diminuindo para menos de 100 milímetros por ano ao sul. A temperatura varia entre menos $20^{\circ} \mathrm{C}$ nas noites de inverno a $20^{\circ} \mathrm{C}$ durante os dias de verão (Fornari et al., 2001).

A região do Antiplano andino exibe contrastes pronunciados de precipitação durante as estações do ano. No verão austral, células de baixa pressão induzidas pelo calor se forma sobre a região central da América do Sul, trazendo umidade do Atlântico Sul. Ao mesmo tempo, a atividade convectiva sobre o Altiplano associado às partes altas da Bolívia produz precipitação nos Andes. Como resultado, a maioria da precipitação ocorre entre dezembro e março. Bloqueios periódicos da circulação atmosférica leste pelas ondas de oeste e perturbações causadas pela ENSO podem produzir fases secas durante a estação normalmente úmida (Abbott et al., 1997).

A cordilheira leste é uma zona de gradientes climáticos acentuados resultantes de desnível de mais de 600 metros acima da bacia amazônica. A precipitação é decrescente de leste a oeste, variando de mais de 1.400 milímetros por ano nas terras baixas a menos de 700 milímetros por ano no Altiplano. A precipitação de verão corresponde de 65 a $78 \%$ da precipitação ao longo do ano, enquanto que no inverno, de junho a setembro caem cerca de $8 \%$ das chuvas anuais (Abbott $e t a l$, 1997) 
A Venezuela está dentro da Zona de Convergència Intertropical (ITCZ), com precipitação anual de 865-1000 milimetros e a estação seca corresponde aos meses de novembro a abril. A temperatura média anual é de $25^{\circ} \mathrm{C}$ principalmente na região do Lago Valência (Leyden, 1985).

O clima no Llanos Orientales é sazonal, com período de chuvas que dura 7 meses, mas exibe gradientes pluviométricos de cerca de 1.200 a 2.000 milímetros por ano ao norte e de cerca de 2.000 a 2.500 milimetros por ano ao sul da região. A temperatura anual média é de $26-27^{\circ} \mathrm{C}$, com variação menor que $3^{\prime \prime} \mathrm{C}$ por mês (Berrio et al., 2000).

A borda meridional da bacia Amazônica situa-se sob clima tropical úmido e topografia constituida de platôs e depressões, sendo essas inundadas por pelo menos 6 meses durante o periodo das chuvas (Pessenda et al., 2001). A temperatura média anual em regiōes próximas ao rio Amazonas é de $27^{\circ} \mathrm{C}$ e a precipitação média é de 2.200 milimetros por ano (Bush et al., 2000).

A Serra do Carajás, por exemplo, corresponde a um estreito platô atingindo altitudes entre 700 e 800 metros. Climaticamente situs-se dentro da faixa noroeste-sudeste da Bacia Amazônica com precipitações anuais entre 1.500 a 2.000 milímetros, indices abaixo de suas regiões vizinhas que chegam a ter de 2.000 a 3.000 milimetros de chuva por ano (Absy et al., 1991)

No pantanal a temperatura média anual é de $25^{\circ} \mathrm{C}$ e a precipitação em torno de 1.280 milímetros por ano, com estação seca de aproximadamente 5 meses. O solo é classificado como areia quartzoza (Victoria et al., 1995).

O clima do Brasil central ocupado pelo cerrado é tropical quente semi-úmido com pronunciada estação seca de 3 a 4 meses de duração. Está relacionado ao deslocamento latitudinal anual da ITCZ. Entretanto, esse padrão geral é alterado por efeito de frentes polares que ocasionam temperaturas muito baixas e até mesmo geadas eventuais. A duração da estação seca ainda é influenciada pela circulação atlântica (Ledru, 1992).

As regiões sudeste e central brasileiras também são controladas pela posição da ITCZ Durante o inverno, as massas de ar polar que avançam para o norte, ao entrar em contato com as massas de ar quente dos trópicos entre as latitudes 25 e $30^{\circ} \mathrm{S}$, induzem precipitações nesta região. (Ledru et al., 1998).

O gradiente pluviométrico está relacionado ao padrão atmosférico dominado pelo anticiclone do atlântico sul, um sistema semipermanente de alta pressão. Durante quase todo o ano esse sistema transporta massas de ar tropicais úmidas para o continente nas direções leste e nordeste. Mudanças neste padrão estão relacionadas a invasões de frentes frias polares, que ao se chocar com as massas tropicais produzem fortes chuvas principalmente na região sudeste (Nimer, 1989) 
A climatologia da região nordeste é bastante complexa devido a sua extensão territorial associado ao tipo de relevo e a conjunção de diferentes sistemas de circulaçăo atmosférica. Essa complexidade não se traduz em grandes diferenças térmicas, mas exibe grande variedade pluviométrica (Nimer, 1989). O clima é semi-árido. A precipitação anual é de cerca de 490 milímetros, com déficit acima de 1.400 devido a evapotranspiração. As chuvas são concentradas entre os meses de fevereiro a maio e a temperatura anual média é em torno de $26^{\circ} \mathrm{C}$.

Ao longo da porção média do rio São Francisco, entre as cidades de Barra e Pilão Arcado, ocorrem 7.000 quilòmetros quadrados de paleodunas. As flutuações no regime de ventos é controlada pelas massas de ar atlânticas equatorial e tropical durante o inverno e pela massa de ar continental equatorial durante o verão. A precipitação varia de 400 a até 800 milímetros por ano (Barreto et al, 1996).

\section{4 - Caracterização dos tipos vegetacionais presentes na América do Sul}

A porção mais ao sul do continente sul-americano chega a apresentar tundra subantártica, muito embora de pequena distribuição, sendo logo substituída pelas vegetações patagônica e magelânica, na região da cordilheira do Andes subdividida em matas perenifólias e matas verdes, enquanto que a leste da cordilheira ocorre as estepes e os desertos patagônicos. Denomina-se vegetação magelânica para todas as matas ao sul das florestas valdivianas. Ao longo de área úmida, numa estreita faixa, ocorrem matas perenifólias, mais ao norte, são substituídas, em maiores altitudes, por vegetação com características de floresta decídua. As matas verdes se distribuem no leste seco do sul dos Andes, com precipitação de 1500 a 500 milímetros por ano. Nas áreas de menor precipitação ocorre estepe, sempre com limite muito nítido entre as vegetações (Hueck, 1972).

A vegetação natural do Chile é dividida em quatro diferentes zonas reconhecidas entre o nivel do mar e a tundra alpina. Remanescentes da floresta decídua das terras baixas mais ao norte, são espalhadas até $41^{\circ} \mathrm{S}$, limite norte da floresta úmida valdiviana e acima de 150-200 metros de elevação (Heusser, 1981).

A região das matas pluviais valdivianas é limitada ao norte pelas matas foliadas verdes de verão e se estende mais para o norte na região costeira. Apresenta este nome por atravessar as corditheiras costeiras na região de Valdivia. Desigualdades no tipo de solo e altitude, ocasionam diferentes tipos de matas. A mata valdiviana propriamente dita é rica em espécies, com predomínio de tipos perenes, em geral com folhas grandes (Hueck, 1972). 


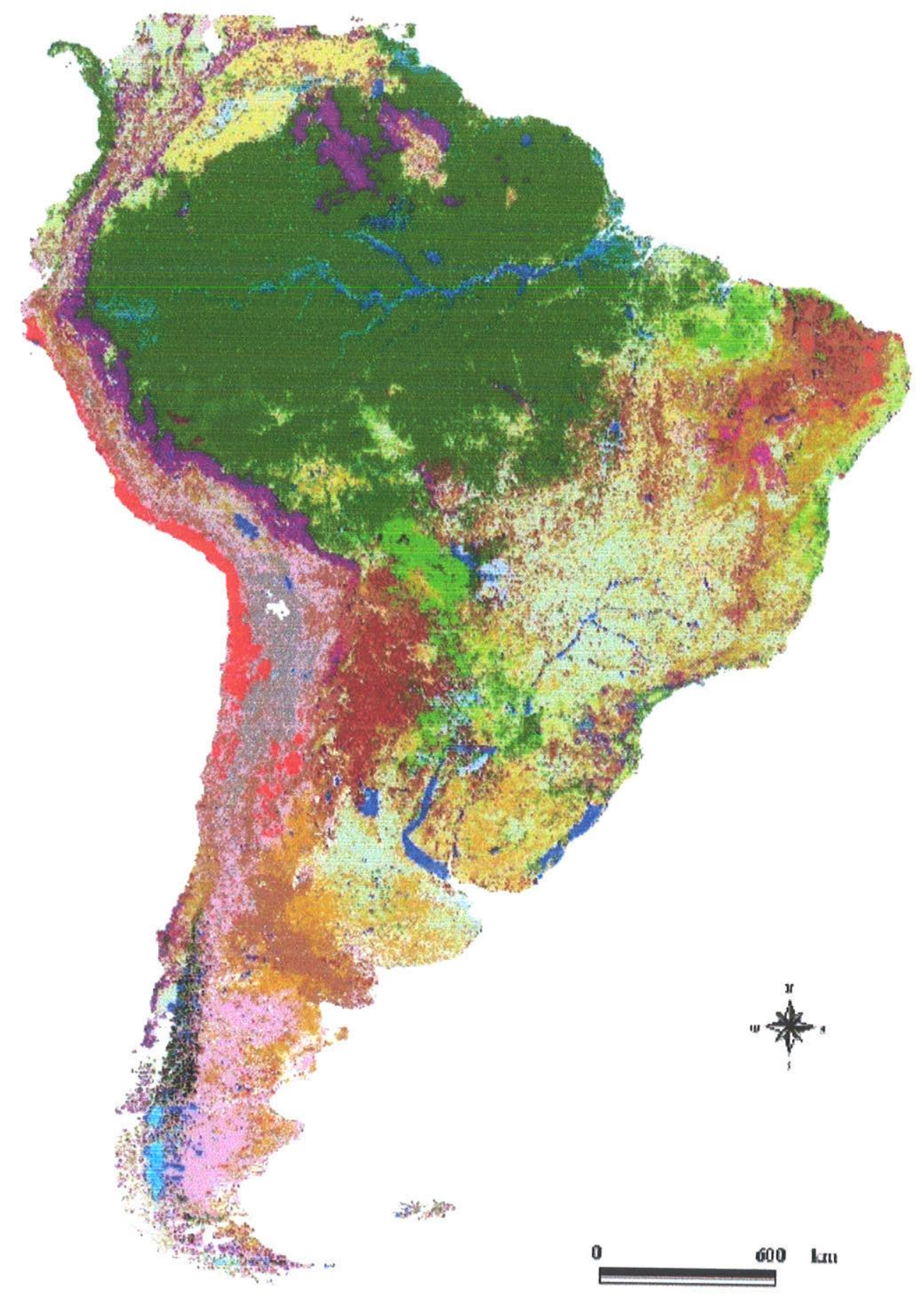

Florestas perenifólias

Florestas montanas

Florestas inundadas

Florestas perenifólias dominadas por bambu

Florestas semidecíduas

Florestas decíduas

Florestas decíduas temperadas

Mangues

Savanas

Transição s๔vana-campo

Campos

Campos montanos

Campos sazonalmente inundados
Savanas sazonalmente inundadas
Estepes e campos limpos
Pântanos
Areas agrículas
Areas agrículas e florestas degradadas
Desertos
Desertos frios
Pântanos salgados
Corpos d'água
Gelo e neve
Areas urbanas

Figura 2 - Mapa ilustrativo da América do Sul indicando os principais tipos vegetacionais. http://www.estadao.com.br/ciencia/noticias/2003/mar/30/69.htm 
Uma larga faixa seca, bem delimitada, de noroeste a sudoeste, separa as matas ao sul dos Andes, da regiăo das matas do norte da América do Sul. No oeste dos Pampas, a precipitação é menor que 400 milimetros por ano e a Patagônia fica abaixo da isoieta de 250 milimetros, com presença de estepes e semidesertos, com a vegetaçăo tornando-se completamente desértica na costa do Pacifico, representada pelo deserto do Atacama (Hueck, 1972).

Ao norte das estepes e ao sul dos pampas, ocorre a região dos montes caracterizada por estepes arbustivas xerófilas, embora extensa e com condições climáticas variáveis. A vegetação é muito uniforme. Já os pampas correspondem à denominação indigena referente ao relevo plano, que inclui as extensas planicies do rio de La Plata, constituido de campos abertos (Hueck, 1972).

Seguindo a cordilheira dos Andes em direção ao norte, a partir da porção central do Chile até o norte do Peru, encontram-se desertos costeiros, continuados pela vegetação de puna e páramo a medida em que a altitude aumenta. A região dos Andes centrais, os vales encontrados entre as diferentes cadeias montanhosas aumentam de extensão, formando extensos planaltıs, com altitudes que variam de 3600 a 4200 metros de altitude, denominado de Altiplano. A vegetação é muito característica de campos de gramineas e estepes baixas. As partes sulinas são extremamente secas, especialmente na Argentina, Bolivia e Peru, sendo denominadas de puna. Por outro lado, ao norte, as condições são mais úmidas, permitindo o desenvolvimento do páramo (Hueck, 1972).

$\mathrm{Na}$ Cordilheira Leste da Colômbia pode-se encontrar florestas tropicais nas terras baixas, savanas ou vegetação xerófita. Até 1.000 metros de altitude encontra-se um cinturão de floresta tropical, de 1.000 a 2.300-2.500 metros ocorre a floresta subandina. De 2.300-2.500 até 3.200-3.500 metros de altitude encontra-se a floresta andina. Acima da floresta andina ocorre o páramo, no qual três cinturões podem ser reconhecidos: o subparamo, o paramo herbáceo e o superpáramo. Considera-se subpárano a vegetação lenhosa arbustiva que pode ocorrer desde os 3.000 até 3.600 metros de altitude. $O$ páramo herbáceo pode se estender de 3.500 metros a 4.200 metros de altitude. O superpáramo, acima de 4.000 metros normalmente apresenta congelamento no solo e a vegetação é bastante esparsa (Hooghiemstra, 1989). Portanto, pode-se notar que o posicionamento da vegetação em relação a altitude é um pouco variado, possivelmente pela conjunção dos fatores climáticos com a geografia de cada região, de modo que as interpretações paleoclimáticas baseadas apenas nesses critérios deve ser vista com cautela.

Nas regiões andinas próximas ao Equador, a vegetação corresponde a floresta tropical altamente diversificada numa transição entre as florestas de altitude e as das planícies, a 1.100 metros de altitude numa das áreas de maior umidade na Amazônia (Liu \& Colinvaux, 1985). 
Nas encostas orientais da cordilheira dos Andes, entre altitudes de 450-550 metros atej 1400 metros ao sul e 2400 metros ao norte, encontram-se comunidades vegetais de grande riqueza floristica, incluindo diversas matas de altitude, desde matas tropicais perenifolias, matas subtropicais, matas de neblina, também perenifólias, matas de altitude, geralmente caduciólias (Hueck, 1972).

Antes de atingir as partes mais ao norte da cordilheira dos Andes, não se pode deixar de mencionar a grande região completamente plana do Chaco, sendo coberta pela floresta seca mais extensa da América do Sul. Estende-se pela Argentina, Paraguai e Bolívia, ocupando 800.000 quilometros quadrados, sendo que apenas uma pequena porção adentra o Brasil. A área central é extremamente seca e o Chaco oriental, mais úmido. Em sua vegetação predominam matas xerófitas abertas, em geral com as folhas pequenas. Em suas bordas percebe-se a influencia do cerrado a leste, da província andina a oeste e da vegetação do sul do Brasil a sudeste. O Chaco oriental t‘́mbém é conhecido como "Parque Mesopotâmico", estende-se pela Argentina sob influència dos rios Paraná, Uruguai e Paraguai, ocorrendo lagos, pântanos, matas de galeria e bosques pouco densos, além das matas deciduas e campos secos (Hueck, 1972).

Partes da América do Sul tropical apresentam mosaico de vegetação de florestas e savanas, que nem sempre são correlacionáveis a fatores edáficos, hidrológicos ou geomorfológicos (Carneiro Filho, 1993). Floresta semidecidua ocorre nas margens da savana, sendo normalmente considerada um estágio transicional entre as florestas sempre-verdes e as savanas (Desjardins et al., 1996).

Em Rondônia, a distribuição das savanas não foi considerada como dependente de fatores edáficos e dados de subsolo sugerem maior desenvolvimento das savanas anteriomente, tendo-se inclusive dados sugestivos da ocorrência de fogo (Desjardins et al., 1996).

Os Llanos Orientales e Llanos Orinoco, na Venezuela representam o maior ecossistema de savanas tropicais no norte da América do Sul. A geomorfologia dessas terras baixas corresponde a planície com algumas áreas altas com relevo suave, denominadas mesetas (Behling \& Hooghiemstra, 1998).

As savanas nos Llanos Orientales podem ser subdivididas em 10 comunidades diferentes: três comunidades àrbóreas que possuem poucas afinidades com as outras sete, que seguem um gradiente de aumento de umidade: três comunidades de savanas secas, duas comunidades de savanas úmidas e duas comunidades de savanas sazonalmente inundadas. A composição e distribuição dessas diferentes comunidades são resultantes de diversos fatores ambientais como físicos, pedológicos, bióticos e climáticos. Ocorrem manchas de florestas e florestas galerias interrompendo a vegetação campestre. As savanas de Llanos Orientales foram consideradas como o ecossistema de menor diversidade floristica da região neotropical (Behling \& Hooghiemstra, 1998) 
Ao longo da costa ocidental do norte da América do Sul não há estação seca e a precipitação chega a ultrapassar 6000 mitimetros por ano, sendo a vegelaçăo predominante floresta pluvial tropical, mas nas regiões de montanhas, a vegetação se altera um pouco, chegando a ter matas deciduas. Na região costeira caribenha da Colômbia e Venezuela, especialmente nas proximidades do Lago Maracaibo, a pluviosidade é baixa e irregular, de modo que a vegetação constitui-se de mata seca com cactáceas. A vegetação comumente denominada de Llanos, corresponde a mata decídua similar às florestas de monções do sul da Ásia (Hueck, 1972).

Pela seqüência escolhida para a abordagem da América do Sul, seguem-se os tipos de vegetação que ocorrem no Brasil. Estas vegetações receberão maior detalhamento.

A fitogeografia tende a utilizar designações regionais que dificultam as comparações de vegetações em diferentes partes do mundo. Poucas nomenclaturas são uniformizadas e muitas não correspondem a sistemas floristico-fisionômico-ecológicos. Normalmente se baseiam em diferentes aspectos (Veloso et al., 1991). Por isso, serão expostas algumas considerações.

Desde a classificação de Martius (1858 apud Veloso et al., 1991), tipicamente floristica, o Brasil é dividido em cinco regiões: Amazônia (Nayades), Caatinga (Hamadryades), Cerrado (Oreades) e Complexo vegetacional Atlântico, dividido entre a costa atlântica (Dryades) e a flora subtropical (Napeias). Segundo Veloso et al (1991), pouco se pode acrescentar a esta classificação, a não ser duas novas regiões: a do Pantanal (Charco Boreal) e a da Campinarana, flora dos Podzóis Hidromórficos dos pântanos amazônicos.

A primeira classificação fisionômica-estrutural foi realizada por Gonzaga de Campos (1926), com terminologia regionalista, mas foi a divisão fitogeográfica de Bezerra dos Santos (1943) que seria a precursora da Fitogeografia Fisionômica no Brasil, seguidas inclusive pelo Projeto RADAMBRASH. Na referida classificação, as formações florestais ou arbóreas são divididas em Floresta Amazônica, Mata Atlântica, Floresta de Araucária, Mata do rio Paraná, Mata de Cocais e Mata de galeria. As formações arbustivas e herbáceas são divididas em Caatinga, Cerrado, Campos Gerais e Campinas ou Campos Limpos. E são duas as formações complexas: Pantanal e formações litorâneas (Veloso et al., 1991).

O primeiro botânico a tentar uma classificação fitogeográfica universal foi Schimper (1903), baseada no conceito de formações. As formações florestais foram divididas em floresta pluvial, floresta das monções, floresta espinhosa e floresta de savana. Formações campestres e formações desérticas. Suas maiores divisões são baseadas em critérios fisionômicos e as divisões menores em critérios climáticos e edáficos. O sistema de Trochain (1957) foi inovador, pois apesar de utilizar critérios fisionômicos, os subdividiu de acordo com o parâmetro ecológico dominante, terminologia aceita e relativamente pouco alterada. O Projeto RADAMBRASIL baseou-se na classificação de 
Ellemberg \& Muller Dombois (1965/66), que obedece a um sistema hierárquico de formaçoes, seguida de subformaçóes (Veloso el al., 1991).

Por tentar obedecer a padrões internacionais, a apresentação da vegetação brasileira utilizou aqui os princípios gerais adotados pelo Projeto RADAMBRASIL, procurando seguir um sistema hierárquico. Dados adicionais serão fornecidos sempre que se considerar pertinente, principalmente para explicar termos regionais algumas vezes encontrados em trabalhos que versam sobre paleoclimatologia, de modo a evitar problemas de interpretação e comparação.

A Floresta Amazônica é o maior ecossistema de floresta chuvosa do mundo com cerca de 5.600.000 quilometros quadrados. Representa $50 \%$ da área total de florestas tropicais chuvosas do planeta. É caracterizada por três tipos principais de florestas, relacionadas ao grau de inundação. A floresta de terra firme, nunca é inundada e corresponde ao tipo mais diversificado. A floresta de várzea pode ser parcialmente inundada e a floresta de igapó, que permanece sazonalmente inundada (Rizzini, 1997). Essa floresta transcende e muito as fronteiras do Brasil, correspondendo a grande floresta pluvial equatorial, presente na área da Bacia do Amazonas e do Orinoco. O clima quente não é caracterizado por temperaturas extremamente altas, mas por temperaturas regulares durante o dia e a noite (Hueck, 1972).

Segundo Hueck (1972), a Amazônia pode ser dividida por regiões: delta do rio Amazonas, região do Paru-Jari (nordeste do Amazonas), região do Tocantins e do Gurupi, região do médio e baixo Xingu e do Tapajós, região dos rios Madeira e Purus, a Hiléia ocidental, região do rio Negro (noroeste da Hiléia), região da várzea dos rios Amazonas e baixo Madeira, região do Acre, Beni, Mamoré e Guaporé, nas proximidades dos Andes, região do Caquetá, Vaupés e Guainia, região dos afluentes da margem direita do rio Orinoco, região das guianas e a região do delta do Orinoco, baseando-se principalmente nos tipos predominantes de vegetação e áreas de transiçăo. Outros autores subdividem a mata pluvial em terra firme, várzea e igapó, além das matas decíduas, savanas e campos abertos inundados ou não. Citam ainda a ocorrência de matas muito mais baixas e mais pobres, caracterizadas por mata rala e abundantemente iluminada, impropriamente denominada de caatinga amazônica.

A floresta de terra firme encontra-se em regiõeśs mais elevadas, de 60 a 200 metros de altitude e corresponde a vegetação perenifólia, latifoliada, compacta e escura. Ocorre em substrato arenoso mais ou menos argiloso. Podem ser reconhecidos quatro estratos: o estrato formador do dossel com 30 a 40 metros de altura, sendo que as emergentes podem atingir alturas entre 50 e 65 metros; o segundo estrato arbóreo com 5 a 20 metros de altura e subordinado a ele, o terceiro estrato, com arbustos, samambaias e pequenas árvores que conseguem viver na penumbra úmida da floresta. O quarto estrato corresponde ao piso da floresta, representado quase que exclusivamente 
pela serapilheira e algumas plantas jovens e ervas. No interior dessa floresta ocorrem as várzeas e os igapós (Rizzini, 1997).

A floresta de várzea é inundada apenas algumas semanas por ano. Representam formaçòes caracteristicas da Amazônia. Floristicamente podem ser diferenciadas as várzeas de rios brancos, que portam muitos sedimentos das várzeas de rios negros. Estando associadas aos nutrientes transportados pelos rios, as várzeas são menos desenvolvidas no Baixo Amazonas. Em geral apresentam-se com três estratos. O estrato superior varia de 10 a 20 metros de altura, embora possa chegar a 30 metros. O estrato inferior é rico em arbustos, lianas, palmeiras e epifitas (Rizzini, 1997).

A floresta de igapó possui drenagem insuficiente porque a água permanece estagnada na maior parte do ano, fornecendo características de mata pantanosa. A vegetação é baixa e pobre, com árvores mais espaçadas, com presença de epifitas. Ocorrem árvores características da floresta de várzea, embora menos desenvolvidas e árvores que são peculiares a este ambiente, sendo mais numerosas (Rizzini, 1997).

Com uma área de 140.000 quilômetros quadrados, o Pantanal corresponde a uma das maiores planícies de inundação do mundo. Devido a variações entre climas secos e úmidos durante o final do Pleistoceno, padrões mistos de vegetação foram estabelecidos com as espécies características das áreas vizinhas (Amazônia, Chaco, Cerrado e Caatinga) e com poucas espécies endêmicas. Há quem acredite que espécies da Caatinga tenham invadido a região nas fases secas (Victoria et al., 1995). Os solos em sua maioria são arenosos e pobres. A temperatura média anual excede os $25^{\circ} \mathrm{C}$. A média de precipitação é de 1.000 a 1.300 milimetros por ano, com $80 \%$ das chuvas concentradas entre outubro e março. A lenta drenagem na imensa planicie aluvial com altitude média de apenas 110 metros controla o regime dos rios determinando o ciclo das cheias.

As condições de habitat variam bastante de acordo com a existência ou não de alagamento e a duração deste alagamento faz com que ocorra um mosaico de comunidades hidrófilas, submersas e natantes, helófilas, higrófilas, mesófilas e até xerófilas. Esse mosaico confere o termo Complexo do Pantanal a região formada pela planície aluvial, também denominada de depressão paraguaia (Rizzini, 1997). A vegetação é portanto ora típica de campo cerrado que pode ceder sem transição a campos limpos. Há também mata densa e escura, que pode ceder lugar para mata conhecida vulgarmente como paratudo. É comum no Pantanal a ocorrência de áreas dominadas por apenas um tipo de árvore como os carandazais e os buritizais. Há ainda a vegetação denominada bosque, na qual ocorrem árvores isoladas cujas copas não se tocam. E finalmente as florestas galerias (Ferri, 1980) 
Os tipos vegetacionais da região centro-sul do país podem ser definidos de acordo com o clima, de modo que o cerrado e o buritizal ocorrem em clima de longa estação seca (4 a 5 meses) e temperatura média de inverno de aproximadamente $15^{\circ} \mathrm{C}$. Em direção ao sul, ocorre floresta semidecídua quando a estação seca dura de 2 a 3 meses e temperaturas médias de inverno estão entre 10 e $15^{\circ} \mathrm{C}$ (Ledru et al., 1998)

O desenvolvimento das diferentes fisionomias do Cerrado e de sua distribuição está sujeito a muitas dissensões. Alguns estudos relacionam o acréscimo de fósforo, nitrogênio e potássio com os tipos gradativamente mais fechados de cerrado. Outros estudos mostram que a variação na fisionomia está fortemente correlacionada com a disponibilidade de água nos solos. E há estudos que sugerem a importância do fogo como fator determinante (Behling, 1995).

O Cerrado pode ser caracterizado pela ocorrência de dois estratos com duas formas de plantas ecologicamente diferentes quanto à estrutura e às reações fisiológicas. O primeiro estrato é dominado por fanerófitas de porte reduzido, de caule e galhos tortuosos e de áizes profundas que atingem o lençol freático. No segundo estrato ocorrem lenhosas providas de xilopódios e folhas coriáceas que coexistem com gramineas que formam tapete rasteiro campestre. Entre seus subtipos encontram-se a savana arbórea aberta (cerrado), a savana parque (campo limpo) e a savana gramíneo-lenhosa (campo sujo) (RADAMBRASIL, 1979). Disseminados entre o estrato herbáceo, encontram-se numerosas espécies de subarbustos que distinguem-se pela altura de 10 a $100 \mathrm{~cm}$, por possuirem vários órgãos subterrâneos de caráter perene, por intensa esclerofilia das partes aéreas que representa proteção extra ao vegetal, microfilia generalizada e deciduidade da parte aérea. Não há ervas no sentido de plantas moles, não se observando vegetais anuais, pteridófitas, rosuladas, suculentas e nem espinhosas (Rizzini, 1997).

Para Rizzini (1997) existem relações sucessionais entre o campo e o cerrado, ocorrendo três formações-climax no planalto Central brasileiro: cerradão em solos profundos, matas secas em depressões aqüíferas e campos limpos em solos arenosos rasos ou duros, nos quais há deficiência real de água durante os meses secos. Seu conceito de cerrado é próprio para a forma típica, distinta do cerradão pela perda da estrutura silvestre, com árvores mais espaçadas, menores, mais retorcidas e vegetação baixa ricamente dotada de gramíneas e subarbustos campestres. Do mesmo modo; o campo cerrado seria apenas uma forma mais pobre, tanto estrutural quanto floristicamente, na qual a prevalência da vegetação baixa é ainda maior. Considera ainda dois tipos subsequeentes: o campo sujo e o campo limpo, o último apresentando apenas vegetação baixa, sem árvores ou com arvoretas muito afastadas entre si. Diferentes formas estruturais podem ocorrer em continuidade ou disjunção. 
O buritizal ou vereda é caracterizado pela palmeira Manuritia flexuosa e poucas outras árvores. Esse tipo de vegetação é comum nos cerrados do Brasil central e nos Llanos da venezuela e Colômbia onde são chamados de morichal (Ferraz-Vicentini \& Salgado-Labouriau, 1996)

Da região sul ao norte do Brasil Central ocorrem três tipos de vegetação nas terras baixas que estão relacionadas ao padrão climático. A floresta de Araucária distribui-se em regiões sem estação seca e temperatura média de inverno inferior a $10^{\circ} \mathrm{C}$. A floresta mesofítica semidecídua apresenta-se em regiões de curta estação seca e temperaturas médias de inverno entre 10 e $15^{\circ} \mathrm{C} . \mathrm{O}$ cerrado ocorre em regiões com quatro meses de estação seca e temperatura média de inverno maior que $15^{\circ} \mathrm{C}$. Para todas, a precipitação varia de 1.500 a 2.000 milímetros por ano, sendo a temperatura média do inverno e a duração da estação seca seus fatores condicionantes (Ledru, 1992).

A Floresta Atlântica corresponde a um complexo vegetacional melhor definido por sua composição florística, abrangendo diversas formações veggetais. Essa floresta possui várias Jenominações como floresta perenifólia latifoliada higrófila costeira, floresta latifoliada tropical úmida de encosta, mata pluvial tropical ou floresta ombrófila densa.

Rizzini (1997) considera a Floresta de Araucária parte constituinte do complexo vegetacional atlântico, que associada a componentes da floresta pluvial, origina diversas comunidades florestais mistas. Essa floresta ocorre continuamente entre as latitudes 24 e $30^{\circ} \mathrm{S}$ primariamente entre 1.000 e 1.400 metros de altitude e na forma de ilhas isoladas entre as latitudes 18 e $24^{\circ} \mathrm{S}$ em elevações entre 1.400 e 1.800 metros

O padrão utilizado no projeto RADAMBRASIL é o mais próximo dos termos conhecidos internacionalmente, embora não se concorde com todos os termos citados. Entre os termos úteis para as descriçôes paleoclimáticas encontram-se os que se referem à estrutura da vegetação, independente da composição florística. Esses termos estão indicados por caracteres em caixa alta.

A FLORESTA OMBRÓfll DANSA algumas vezes, denominada de floresta pluvial, caracteriza-se por árvores perenifoliadas, com dominância de fanerófitas ombrófilas sempre verdes em todos os estratos, sendo numerosas as epífitas. Precisa existir num espaço sem período biologicamente seco, explicada pela maior retenção de água em determinados solos e/ou pelo recebimento extra de umidade relativa através de nevoeiros e de orvalho, de modo que localização geográfica e altitude são de importância fundamental.

$\mathrm{Na}$ vegetação atlântica esse tipo de floresta pode ocupar altitudes superiores a 500 metros; Como submontana, entre 50 a 500 metros ou como floresta de terras baixas.

A vegetação atlântica fisionomicamente exibe árvores recobertas por musgos e povoadas por lianas e epífitas, em geral possui estrato arbóreo com algumas emergentes, estrato arbustivo e estrato herbáceo em pequena quantidade. Nas serras a Mata Atlântica ascende até 1.500 a 1.700 
metros na sua forma típica, daí para cima, é substituida por formas empobrecidas em pontos favoráveis, acima de $1.800-2.000$ metros encontra-se vegetaçăo arbustiva e campestre

Segundo Rizzini (1997), a vegetação atlântica seria definida pela Fl.orlsSTA PI.UVIAI. MONTANA ocorrente entre 800 e 1.500 -1.700 metros, com dossel superior atingindo 20 metros de altura e emergentes podendo chegar a 40 metros. Ocorrência de sinúvia arbustiva e maior abundància e diversidade de epifitas. A floresta pluvial de baixa montana ocorre entre 300 e 800 metros de altitude, com desenvolvimento menor que a pluvial montana, seu estrato superior atinge 15 a 20 metros de altura, com maior espaçamento e ausência quase completa de lianas, epifitas, plantas micrófilas, palmeiras e fetos arborescentes. Entretanto, essa floresta apresenta estrato arbustivo-arbóreo e outro arbustivo.

Pode-se notar que os padrões que definem os tipos florestais brasileiros variam a depender da autoria. Rizzini (1997) considera ainda a floresta pluvial ripária (mata galeria) e a em manchas (capões), que se desenvolvem a depender do substrato e altitude.

Outros tipos florestais estão associados a essa vegetação como a FLORESTA ESTACiONAL. SEMIIDECLDUAL, caracterizada por apresentar de 20 a $50 \%$ de árvores caducifólias. Poucas espécies são epifitas, mas há numerosas lianas.

A FLORESTA ESTACIONAL SEMIIECIDUAI, representa o fenômeno periódico de simultânea perda de folhas de parte (ou quase totalidade) dos componentes essenciais da formação florestal. Para o RADAMBRASIL, a região estacional está relacionada ao clima de duas estações, uma seca e outra chuvosa. No espaço nordestino, essa floresta responde a período de seca variando de 4 a 6 meses secos e altas temperaturas (acima de $22^{\circ} \mathrm{C}$ ). Esta floresta também é subdividida em aluvial, de terras baixas, de submontana e montana, seguindo os mesmos critérios anteriores.

A FLORESIA ESTACIONAL DECIDUAL, semelhante a anterior, varia apenas na intensidade da decidualidade foliar que passa a ser de $50 \%$ ou mais na época mais seca. Não é comum no sudeste do Brasil, ocorrendo na forma de algumas manchas no nordeste em locais com período seco mais prolongado, de até 7 meses, de altas temperaturas (médias anuais maiores de $20^{\circ} \mathrm{C}$ ) e da textura dos solos que a sustentam. Também é chamada de floresta estacional caducifólia não espinhosa, mata seca, mata de cipó e agreste. Embora esses termos aparentem ter diferenciação na região nordeste, sendo a mara seca subdivisão da zona da mata pernambucana, normalmente corresponde a floresta semidecídua. Quanto à expressão mata de cipó, designa tão somente o tipo decidual. Próximo a região de Minas Gerais adota-se o termo mata de fechado. Ao contrário do tipo semidecidual, só ocorrem os subtipos de submontana e montana (RADAMBRASLL, 1979). Devido a proximidade desta floresta com a floresta estacional semidecidual, nem todos os botânicos concordam que este tipo estrutural ocorra de fato no Bioma Atlântico. Entretanto, a floresta estacional decidual que 
corresponde ao Bioma Caatinga, apresenta características diversificadas conforme será comentado a segutis.

A Caatinga é definida como um tipo de vegetação xerófita contendo essencialmente arbustos e árvores espinhosas e decíduas associadas a plantas suculentas, cactos e bromélias (Kuhimann, 1977). A vegetação estrutura-se em três estratos: um estrato arbóreo com árvores de 8 a 10 metros de altura, um estrato perene de arbustos espinhentos e uma camada herbácea sazonal.

A caatinga nordestina, com seus diversos tipos estruturais, encontra similares em todos os continentes, particularmente na própria América do Sul e na África tropical. É o caso do Chaco, vegetação dominante na Argentina mas também presente no Paraguai, Bolivia e numa pequena faixa de Mato Grosso. Na Venezuela, vegetação idêntica é denominada bosques xerólilos de Maracaibo, embora sua composição florística seja um pouco diferente, ocorrem gêneros comuns (Rizzini, 1997).

A caatinga é excessivamente heterogênea quanto à físionomia e estrutura, entretanto, sua composição é bastante uniforme, havendo um núcleo de espécies arbóreo-arbustivas e de cactáceas dispersas por toda parte. Tal uniformidade permite que se conheçam até por nomes populares. É normalmente dividida em duas faixas vegetacionais baseada no grau de umidade: agreste e sertão, sendo o último a caatinga no sentido habitual.

Para descrever sua fisionomia e estrutura utilizam-se os termos: agrupada, quando as cactáceas, bromeliáceas e arbustos tendem a dispor-se em moitas densas, sobrando espaços vazios; arbustiva esparsa, na qual os arbustos alcançam cerca de 2 metros e as cactáceas estão dispersas; arbustiva densa, com arbustos ramificados formando emaranhado compacto com 2 a 3 metros, com arvoretas de 5 a 6 metros; arbustiva com suculentas e arbórea, com árvores de 8 a 10 metros, algumas bem grossas e outras plantas de desenvolvimento mais vigoroso (Rizzini, 1997).

As evidências botânicas são baseadas em centros de endemismo e distribuição disjunta e em menor extensão às adaptações xerófitas das plantas de florestas chuvosas e na variação dos padrões de espécies polimórficas. São igualmente pouco estudadas as possibilidades de cada área representar refúgios em diferentes áreas de forma a acumular as espécies de cada época de refúgio, um processo denominado padrão de distribuição multiestratificado (Prancè, 1982).

Outros aspectos da Caatinga são apresentados no capítulo 4 referente aos aspectos do local em estudo, incluindo as diferentes nomenclaturas botânicas utilizadas.

As áreas de tensão ecológica ocorrem quando duas ou mais regiões fitoecológicas entram em contato. Essas áreas são divididas em encraves e ecótonos. No mosaico específico ou encrave, cada mosaico de vegetação guarda sua identidade sem se misturar. No caso dos ecótonos ou mosaicos pauciespecíficos, ocorre interpenetração de vegetações que tem estruturas semelhantes 
como floresta ombrófila e floresta estacional, de modo que a identidade ecológica passa a ser ao nivel de espécies (RADAMBRASHL, 1979).

Toda e qualquer vegetação floristicamente diferente do contexto geral da flora da região foi considerada como refügio ecológico pelo RADAMBRASIL. Na area da folha SC.24 encontram-se os Refúgios tropicais de altitude. 
3.1 - Localização geográlica e morfologica dos tufos calcários de Campo formoso

Os tufos calcários em estudo se localizam no municipio de Campo Formoso e em suas vizinhanças, na porção norte do Estado da Bahia, cerca de 385 quilometros de Salvador e 130 quilômetros ao sul de Juazeiro, próximo a Senhor do Bonfim. O acesso via Salvador é feito pela rodovia BR-324 até Capim Grosso, seguindo-se pela BR-407 até Senhor do Bonfim, distante 28 quilometros de Campo Formoso. A oeste desta cidade, afloram os tufos calcários, próxima a Lage dos Negros, onde se encontra uma das mais extensas cavernas brasileiras, com mais de 80 quilòmetros de galerias mapeadas (Rubbioli, 2000).

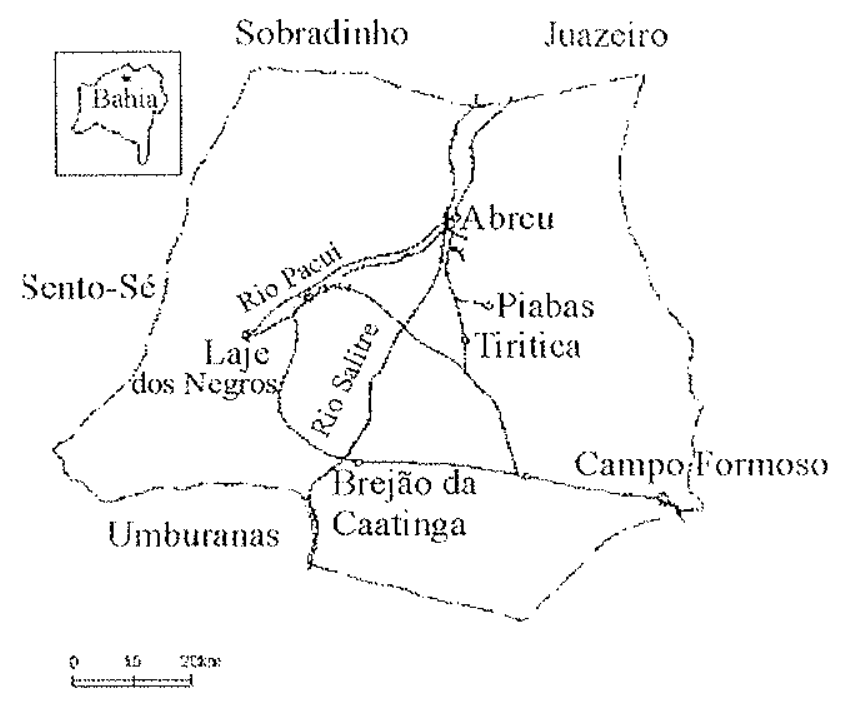

Figura 3 - Município de Campo Formoso: hidrografia, localidades e municípios limítrofes. Adaptado de Rubbioli \& Pilo (1995) e Rubbioli (1996).

Na região ocorrem chapadas, morros residuais e superficies aplainadas. Estas feições são normalmente controladas pela geologia: as chapadas formadas pelo predomínio dos quartzitos précambrianos da Formação Morro do Chapéu, enquanto os morros residuais e superfícies aplainadas são constituidos pelos dolomitos pré-cambrianos da Formação Salitre (Figura 4).

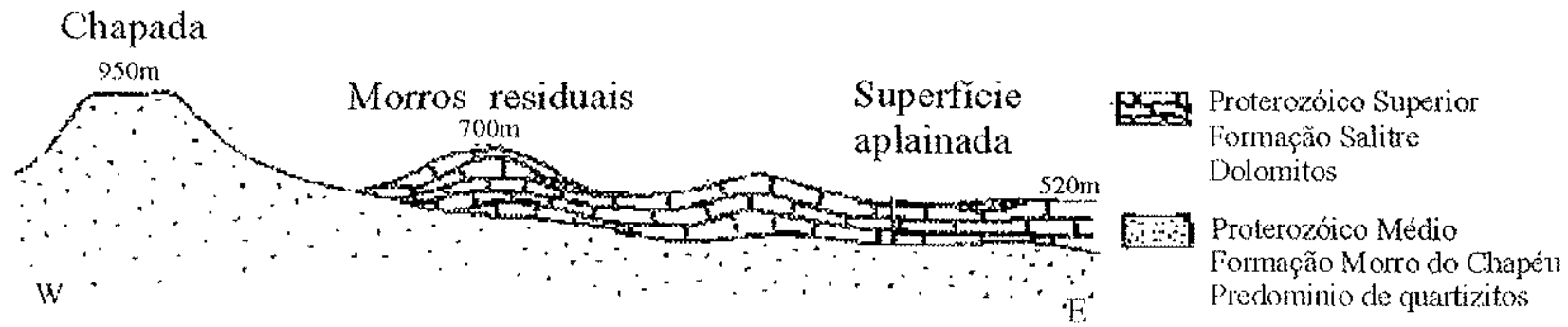

Figura 4 - Perfil geológico de Campo Formoso, BA. Modificado de Rubbioli \& Pilo, 1995 
O rio mais importante da área é o rio Salitre, que é afluente do rio São Francisco. O rio Salitre e seus tributários são efèmeros, com a água corrente presente apenas após raros eventos de alta precipitação. Náárea em estudo, o ro Pacuí, embora menos desenvolvido do que o Salitre, apresenta parte de seu curso perene devido a uma surgência. Junta-se ao Salitre conforme visto na figura 3. O rio Salitre possui vales largos e bem encaixados, sendo seus tributários também bem encaixados, entre eles o Piabas.

A - Tulo de Salgadinho
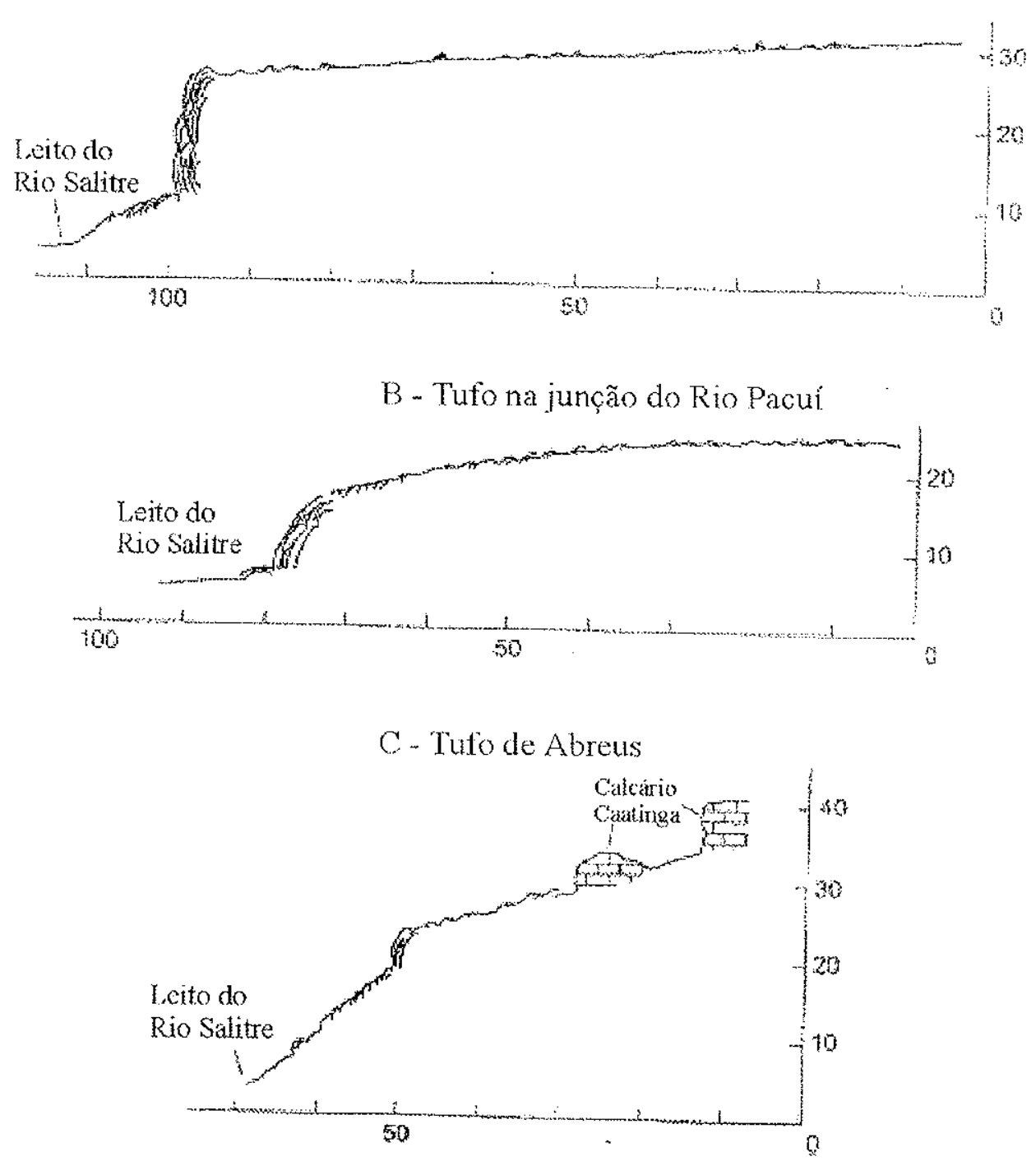

Figura 5 - Morfologia de três ocorrências de tufos estudados por Auler (1999), mostrando apenas a porção distal dos depósitos. As seções são perpendiculares ao vale do Rio Salitre. Escalas em metros.

Observando a figura 5 , os tufos aparentam estar intimamente associados a quedas d'águas, processo que ocasiona a perda de $\mathrm{CO}_{2}$ e a conseqüente precipitação do carbonato. 
A figura 6 ilustra os três afloramentos estudados vistos em planta, indicando os respectivos pontos de coleta de amostras. Nem todos os pontos observados em campo foram amostrados, com exceçăo do afloramento Fazenda Bento, dada a riqueza fossilifera deste afloramento.
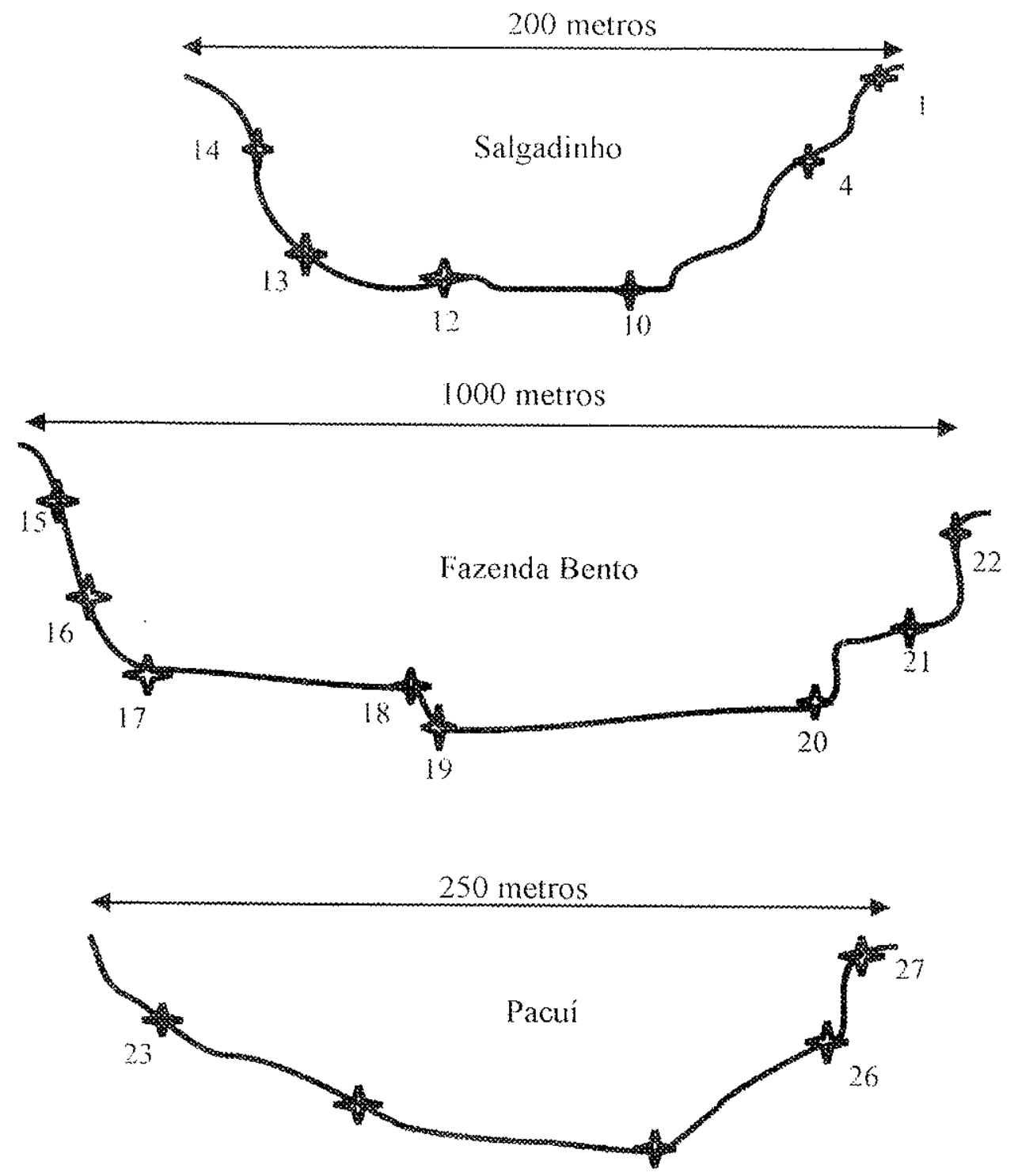

Figura 6 - Esquema em planta dos três afloramentos indicando os pontos de coleta.

Em associação direta ao vale do rio Salitre, os afloramentos estão situados na margem direita, entre as cidades de Brejão da Caatinga e Abreus (Figura 7). O afloramento mais ao sul corresponde ao tufo de Salgadinho talvez corresponda a ocorrência citada por Branner (1910 apud Auler, 1999). Ocorre ao longo de 200 metros e forma várias cavidades pouco profundas. Afloramento este com datações mais antigas, tendo sido bem amostrado para a presente pesquisa. 
Cerca de 6 quilometros ao norte, ocorre o tufo calcário de Lagoa Branca, bem próximo à vila de mesmo nome, mas o depósito não é observado in situ, tendo-se acesso apenas a alguns blocos soltos. Logo após, a cerca de dois quilometros, encontra-se o de late Branco, com vários metros de extensão e com menos de dois metros de altura. Este tufo calcário encontra-se associado a um tributário. Nenhum destes afloramentos foi amostrado devido à falta de datação.

Entre os tufos calcários de Salgadinho e Lagoa Branca, relativamente eqüidistante, foi registrado o tufo calcário denominado Salgado, no qual realizou-se pequena amostragem. Não tendo sido estudado por Auler (1999), não possui datação conhecida

O maior depósito de tufo calcário descrito por Auler (1999), corresponde ao da Fazenda Bento, associado ao rio Piabas, estendendo-se por mais de um quilômetro ao longo do rio Salitre. Seria ainda maior, uma vez que está erodido.

A aproximadamente 20 quilometros mais ao norte, na junção com o rio Pacui, ocorre outro depósito de tufo calcário, com cerca de 250 metros de largura e seis metros de altura. Logo adiante, outra ocorrência de menor porte, constitui o tufo calcário de Abreus com apenas 50 metros de extensão. Este é o único tufo calcário não associado a um tributário, talvez resultado de erosão de possivel ligação com o tufo calcário de Pacuí. A cidade de Abreus pode ser usada como referência para a localização dos tufos em relação ao município de Campo Formoso, ilustrado na figura 3 (página 24).

\section{2 - Aspectos geológicos}

Este tipo de depósito será comentado no capítulo 5 , que versa sobre a deposição de tufos calcários e análise tafonômica para facilitar a compreensão dos seus processos de deposição.

Os tufos calcários aqui estudados representam depósitos resultantes da solubilização de calcários mais antigos, no caso os da Formação Caatinga, que ocorrem extensamente ao longo do rio Salitre. Esses calcários são superpostos por leques detríticos supostamente de idade terciária e quaternária, assim como depósitos aluviais recentes, conforme Figura 7.

Os tufos foram datados por U/Th correspondentes a idades minimas, pois as amostras foram extraidas de calcitas menos porosas encontradas na porção superior dos depósitos. As idades do Salgadinho através da análise de duas amostras, são: $21.400 \pm 500$ e $14.700 \pm 500$ anos, representativas do período no qual permaneceu ativo; os tufos da Fazenda Bento, $10.600 \pm 500$ anos e Pacuí, $9.700 \pm 300$ anos (Auler, 1999; Auler \& Smart, 2001). 


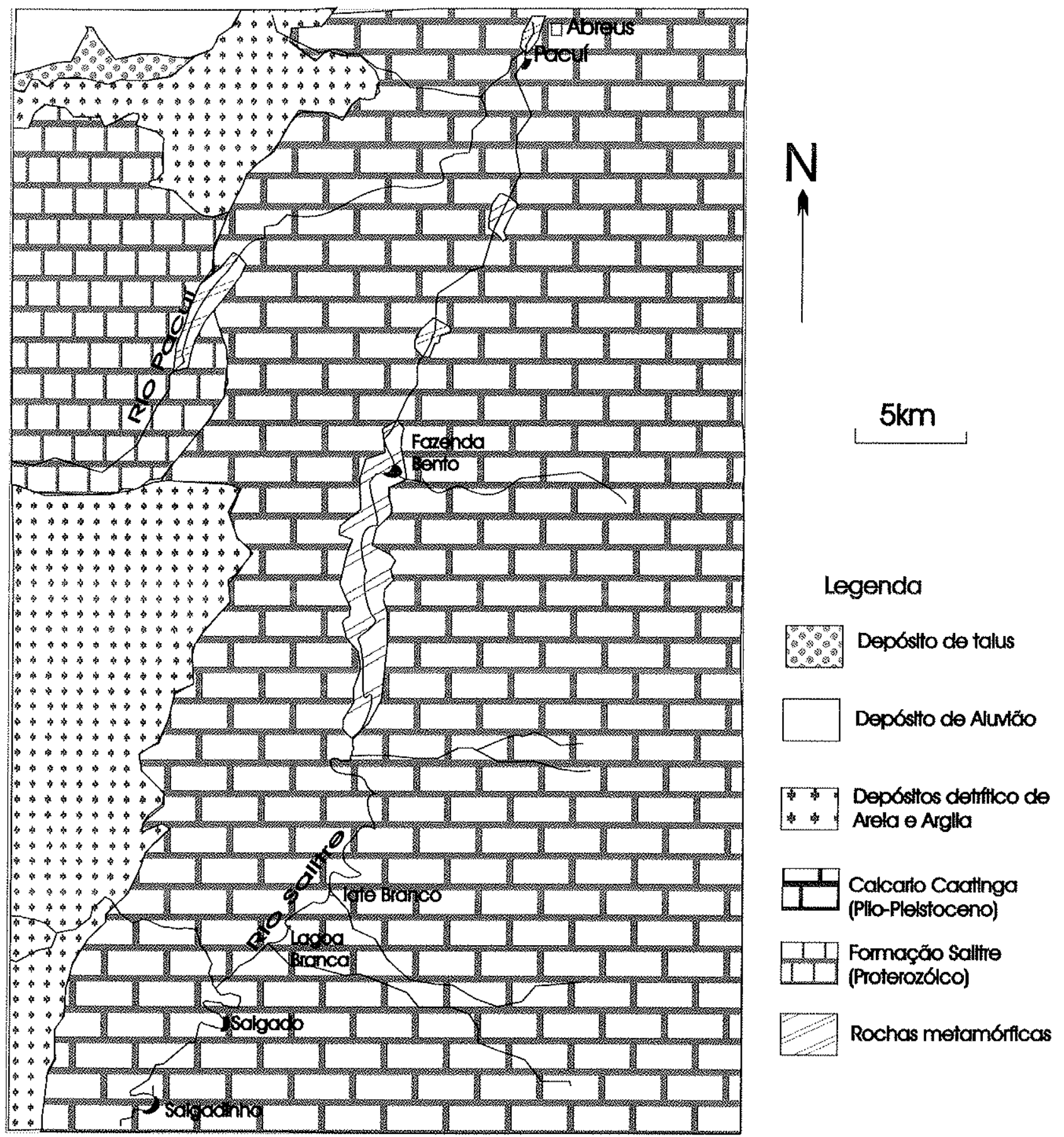

Figura 7 - Localização dos tufos calcários estudados no contexto geológico da área circunvizinha ao carste de Campo Formoso, BA. Modificado de Auler \& Smart (2001). 
3.3 - Localização da área de tufos ativos em Bonito, MS

Para fins de entendimento dos processos envolvidos na precipitação de tufos, foi escolhida uma segunda área de estudos, indicada na figura 8, com a deposição de tufos ainda em atividade, na região cárstica da Serra da Bodoquena, nas proximidades de Bonito, MS. Depósitos de tufos, atribuidos ao Quaternário, ocorrem por toda a região (Boggiani \& Coimbra, 1995; Boggiani et al., 2000) como coberturas (micritas inconsolidadas) nas planícies da Depressão do Rio Miranda, sobre o Planalto da Bodoquena e em atividade ao longo de muitos rios, como os rios Formoso, da Prata, Sucuri, Formosinho, Anhumas, Mimoso, do Peixe, Salobro, pertencentes à Bacia do Rio Miranda e os rios Perdido e Aquidaban da Bacia do Rio Paraguai.

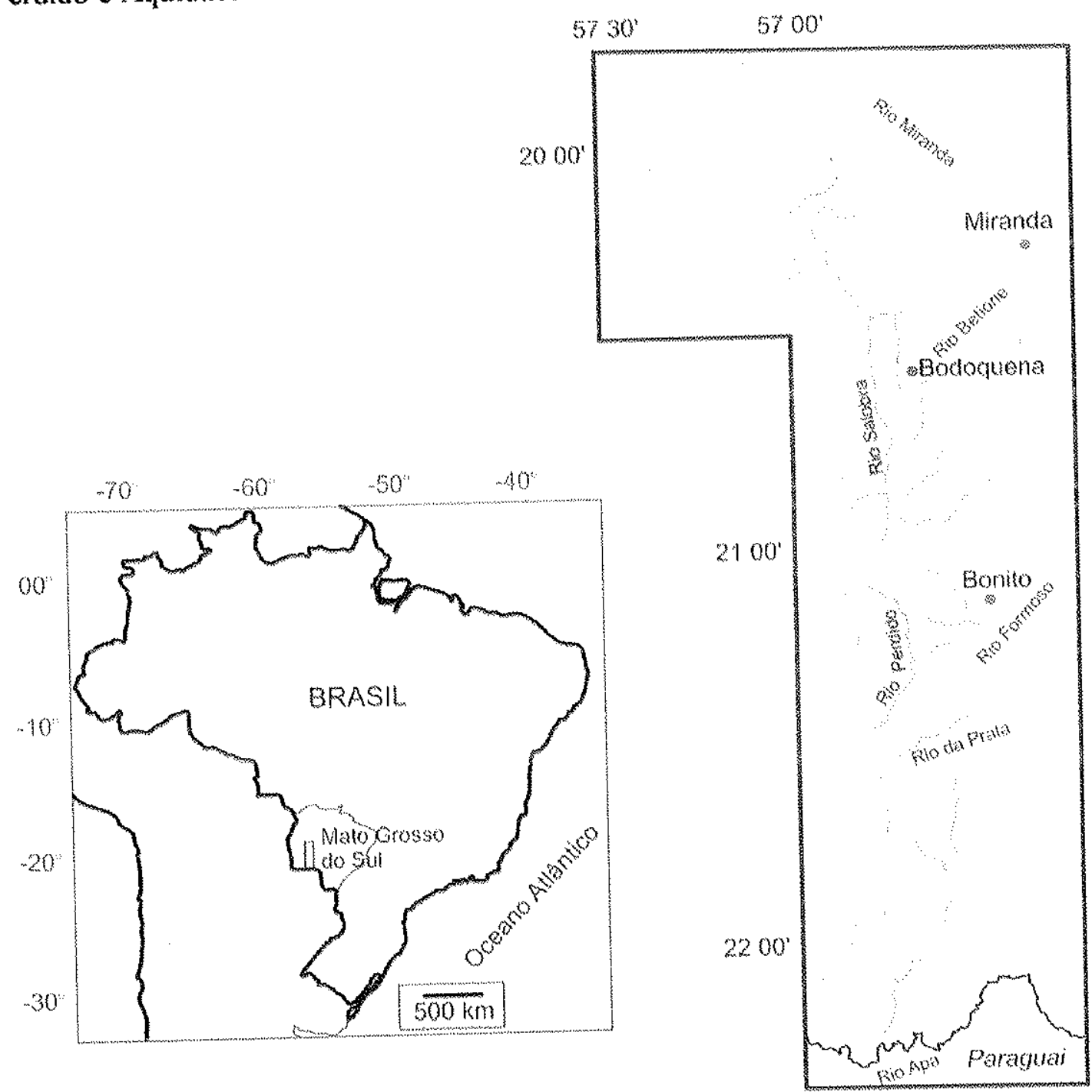

Figura 8 - Mapa de localização dos rios estudados na região de Bonito, MA. A área em cinza representa região de calcários. Figura gentilmente cedida por Sallum-Filho, 2005. 
3.4 - Aspectos climatológicos atuais da região de Campo formoso

A área de estudo, situada no vale do Rio Salitre, município de Campo Formoso-BA, é uma das poucas áreas de clima árido em todo território nacional. O clima na região é classificado como EdA' segundo Thornthwaite (Thornththwaite \& Mather, 1957), que é caracterizado por precipitação média acumulada entre 300 e 500 milimetros por ano, ausência de excedente hídrico e defíciência hídrica que varia entre 834 a 1401 milímetros (SEI, 2005). As temperaturas mantêm-se relativamente altas ao longo de todo o ano e variam em média entre 21 e $27^{\circ} \mathrm{C}$. Portanto, essa combinação climática inibe a formação de tufos carbonáticos nos dias atuais, principalmente devido ao limitado escoamento superficial de água nos córregos tributários do Rio Salitre, onde estão dispostos os principais dépositos de tufos fossiliferos da região.

A estação chuvosa estende-se de novembro a abril, com as chuvas concentradas principalmente nos neses de janeiro, fevereiro e março (Rao \& Hada, 1990). A variação interanual e intersazonal na região de estudo está relacionada com progressivo movimento e intensidade da ITCZ (Rao \& Hada, 1990; Rao et al. 1996). Esse sistema exerce influêtncia vital na variabilidade das precipitações, principalmente no setor norte do Nordeste do Brasil, onde predomina clima semiárido, apesar da cobertura máxima de nuvens da ITCZ posicionar-se a $\sim 3^{\circ} \mathrm{N}$, na zona de máxima temperatura da superficie do mar (Nobre \& Shukla, 1996). A ITCZ encontra-se a norte da sua posição média nos periodos de verão nos hemisférios norte (julho a agosto) e a sul (dezembro a fevereiro), respectivamente.

O fenômeno ENSO produz grande impacto no posicionamento da ITCZ devido à sua influência na variação da temperatura da superfície do mar do Atlântico tropical e conseqüentemente na pluviosidade no semi-árido nordestino. A variação da circulação atmosférica durante os eventos de El Niño provoca anomalias positivas de temperatura na faixa tropical do Atlântico, o que resulta em fraco gradiente de temperatura da superfície do mar e menor deslocamento da ITCZ em direção ao hemisfério sul, induzindo fases de estiagem no Nordeste do Brasil (Uvo et al. 1998; Paegle \& Mo, 2002; Ambrizzi et al., 2004) O contrário é válido durante os eventos tipo La Niña, em que se observa forte gradiente de temperatura da superficie do mar devido a temperaturas anomalamente mais baixas a norte. Estes trabalhos mostram que a influência do ENSO ocorre principalmente nos meses de abril e maio. 
3.5 - Aspectos ambientais que condicionam a distribuição da vegetação

\subsection{1- Relevo}

As províncias fitogeográficas năo necessariamente coincidem com as regiōes geográficas de mesmo nome. Assim, áreas geográlicas da América do Sul caracterizadas como Pampas, Patagônia, Amazônia ou Chaco, não implicam em vegetação homogènea. O mesmo pode ser dito para a região da Caatinga que, conforme exposto anteriormente, inclui áreas com vegetação de cerrado ou áreas mais úmidas como os denominados "brejos" (Prado, 2003).

Cerca de $80 \%$ do território da Bahia está situado acima de 200 metros de altitude, denotando assim domínio montanhoso. Do mar para o interior, observam-se três unidades principais de relevo. A planície litorânea abarca altitudes abaixo dos 200 metros, com pequenas elevações, sob forma de colinas, morros e tabuleiros. Rios correm planalto abaixo espalhando-se por planícies inundáveis. Os rebordos do planalto podem ser considerados unidade de relevo por estarem situados a oeste dos morros e colinas, em terrenos bastante acidentados separando naturalmente a planície. Os planaltos ocupam a maior parte do Estado da Bahia podendo ser subdivididos em cinco porções:

a) Planalto Sul Baiano - situa-se no sudeste do Estado com altitudes médias variando de 800 a 900 metros. Sua superficie ondulada é cortada pelos rios das Contas, Pardo e Paraguaçu.

b) Espinhaço - atravessa a região central do Estado no sentido norte-sul, em altitude média de 1.300 metros, abrigando grandes elevações locais, como a Chapada Diamantina ao norte. O planalto do Espinhaço constitui-se no divisor de águas, separando os afluentes do rio São Francisco dos demais rios que seguem para o Atlântico.

c) Depressão São-Franciscana - está à oeste do Espinhaço, desenvolvendo-se também no sentido norte-sul. As altitudes são baixas (400 metros) e planas, inclinando-se rumo ao rio São Francisco. $O$ fundo desta depressão constitui-se em uma planície aluvial inundada durante as cheias.

d) Planalto Ocidental - Altitude média de 850 metros, localizado na porção oeste do rio São Francisco. Recebe vários nomes a partir de localidades como, Espigão Mestre - divisa da Bahia com Goiás e Serras do Piauí e Tabatinga - divisa entre Bahia e Piauí.

e) Encosta do Planalto - situa-se no nordeste do planalto, caracterizando-se por superficies planas com algumas elevações e escarpas isoladas. As altitudes variam entre 200 e 500 metros. Ela é pouco inclinada a leste para o rio São Francisco e a norte para o litoral (Cabral, 2000). 


\section{6 .2 - Clima}

Très tipos climáticos são identificados no Estado, com pequena variação climática em uma mesma região. A maior parte do Estado é caracterizada por clima quente e úmido, subdividindo se em:

Clima de savana - Ocorre em quase todo o sertão (interior), exceto ao norte, sendo marcado por chuvas abundantes durante o verão, com 1.000 milímetros por ano de precipitação e periodos de rigorosa seca no inverno. A temperatura média anual é de $20^{\circ} \mathrm{C}$;

Clima super-úmido - Está presente no litoral, desde o Recôncavo até o Espírito Santo, sem estação seca. $O$ indice pluviométrico é mais elevado, atingindo 2.000 milímetros por ano em Ylhéus. A temperatura média anual é de $23^{\circ} \mathrm{C}$;

Clima semi árido quente - Distribui-se de norte para leste do planalto. As chuvas são mais escassas chegando a 700 milímetros por ano. Na localidade de Raso da Catarina, região quase desértica com período seco de quase nove meses, as chuvas anuais chegam a 500 milímetros. As médias anuais de $25^{\circ} \mathrm{C}$ de temperaturas registradas neste tipo de clima, são as mais elevadas da Bahia;

Clima tropical de altitude - Na Chapada Diamantina e no Espinhaço (altitudes superiores a 900 metros). Caracteriza-se por invernos frescos e verões amenos, com temperaturas na faixa dos $18^{\circ} \mathrm{C}$ (mês mais frio) e $21^{\circ} \mathrm{C}$ (mais quente).

A classificação ecológica do clima é feita utilizando-se essencialmente a temperatura e a pluviosidade. Diversos índices climáticos foram criados para explicar a distribuição da vegetação. $O$ índice de aridez de De Martonne está entre os principais. Ele é definido pela relação entre a pluviosidade anual expressa em milímetros (P) e a temperatura média anual em centígrados (T) somado a $\operatorname{dez}\left(\frac{P}{T+10}\right)$. O índice é tanto mais baixo quanto mais árido. $\mathrm{O}$ índice de Gausser considera que a secura se estabelece quando a pluviosidade mensal é inferior ao dobro da temperatura média mensal (Dajoz, 1983). Comparando os diversos índices, chega-se a conclusão que grande parte do Nordeste é semi-árido.

Particularmente a Caatinga, está sujeita a condições climáticas extremas quando comparadas a outras formações brasileiras: maior radiação solar, baixa nebulosidade, a mais alta temperatura média anual, as mais baixas taxas de umidades relativas, evapotranspiração potencial mais elevada e, sobretudo, precipitações mais baixas e irregulares (Prado, 2003). 


\section{4 - Métodos e técnicas}

4.1 - Macrofitofósseis como indicadores paleoclimáticos

Os vegetais são bons indicadores climáticos devido à dependência direta de parâmetros, tais como temperatura e umidade, que são muito importantes no processo fotossintético. Acredita-se assim que a fisionomia das folhas reflita o ambiente climático (Bailey \& Sinnott, 1916; Wolfe, 1971; 1979; 1985; 1990; Christophel \& Greenwood, 1989). Vegetações com composições floristicas diferentes terão uma composição fisionômica semelhante quando sob o mesmo tipo climático (Wolfe, 1978).

Comparativamente, os palinomorfos são muito abundantes no registro paleobotânico, possuem relativa resistência à destruição, são indicadores tanto temporais quanto florísticos e possuem características constantes para cada espécie. No entanto, a contaminação por grãos de pólen e esporos transportados de longas distâncias, a redeposiçăo de formas mais antigas, as variaçōes divergentes de uma espécie e a dificuldade de reconhecimento de hiatos deposicionais, podem, muitas vezes, prejudicar boa parte de objetivos baseados em suas pesquisas (Dorf, 1964).

Os macrofitofósseis, dada à natureza delicada das folhas, flores e frutos, podem ser transportados apenas a distâncias limitadas antes de sofrerem decaimento, ruptura mecânica e seleção hidrodinâmica. Com a característica de serem depositadas relativamente próximas a suas origens e de apresentarem morfologia adaptativa como resposta quase imediata às condições ambientais, as folhas constituem importantes elementos para inferências paleoclimáticas. Dada sua complexidade e morfologia diversificada, as folhas fornecem grande número de caracteres diagnósticos importantes. (Christophel \& Blackburn, 1978).

\section{2 - Os tipos vegetacionais atuais da Bahia como parâmetros de comparação}

A figura 9 mostra um mapa de vegetação da Bahia, com indicação dos principais municípios com vegetações estudados fisionomicamente. Na Bahia distinguem-se três domínios vegetacionais principais, geralmente denominados de Mata Atlântica, Caatinga e, a oeste do Estado, Cerrado. O cerrado, por sua vez, distribui-se predominantemente na região do Planalto Central, irradiando-se também para outras áreas do sul e nordeste brasileiros, principalmente em elevações como a Chapada Diamantina na Bahia. Sua fisionomia é savanóide, caracterizada pelo estrato arbustivoarbóreo descontínuo e pelo estrato contínuo de herbáceas. As árvores e arbustos são tortuosos e possuem, em geral, casca grossa (Fonseca \& Brazil, 2004). 


\section{Cobertura vegetal da Bahia}

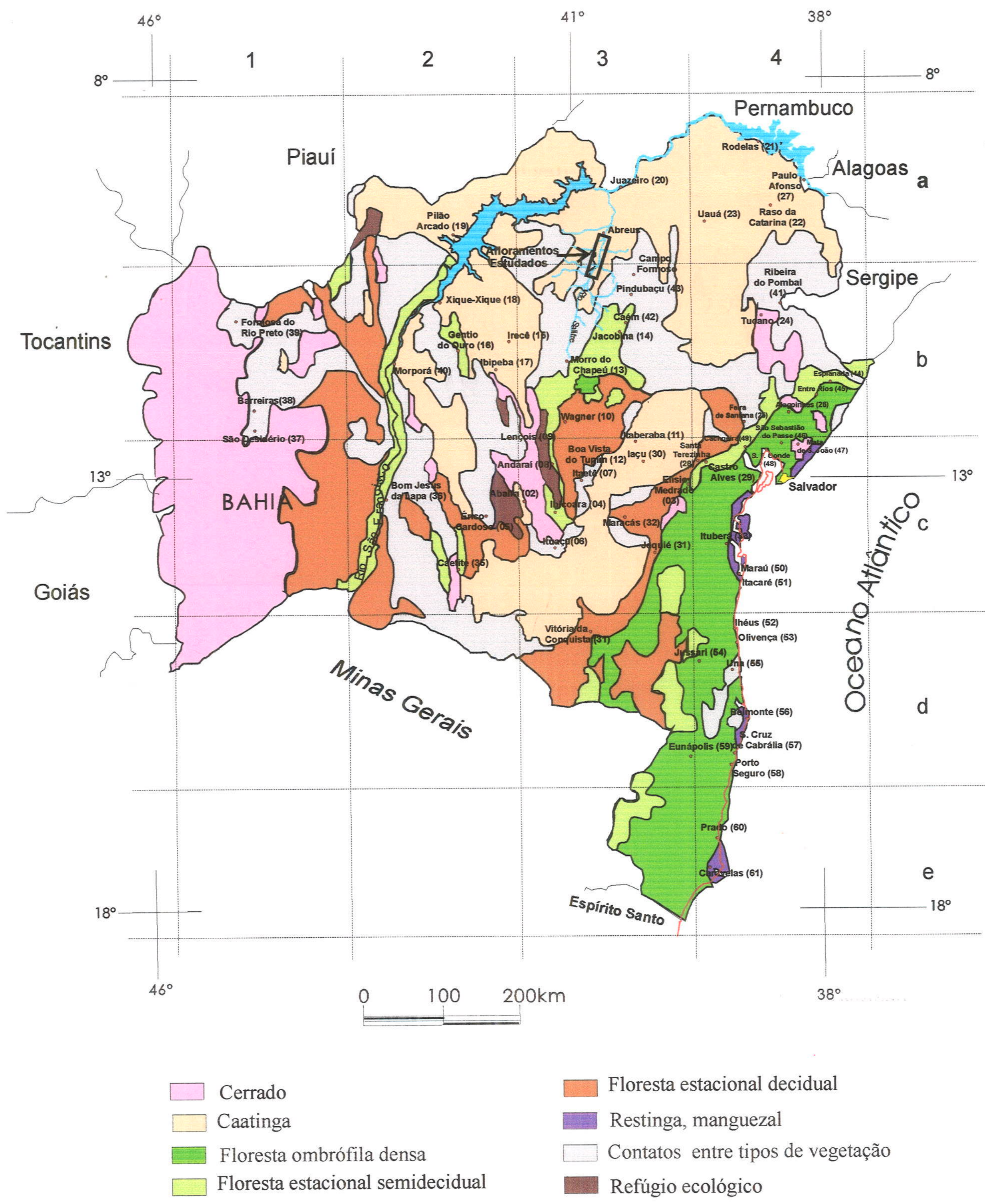

Figura 9 - Aspectos vegetacionais da Bahia. Adaptado do SEI (www.sei.ba.gov.br) 
Não se pode deixar de mencionar, os denominados Campos de Altitude, correspondentes às formaçōes Moristicas situadas nas partes elevadas dos maciços montanhosos do leste brasileiro, constituidas principalmente por especies arbustivas e campestres (Santos, 2004). Muitas vezes essa vegetação é incluida no bioma cerrado.

Como ambiente característico do Nordeste brasileiro, a Caatinga constitui um complexo de vegetação que inclui desde matas caducifólias até áreas semi-desérticas, com predominância de poucas espécies de cactáceas. Na Caatinga também ocorrem áreas úmidas condicionadas a altitude e a exposição aos ventos alísios, principalmente os de sudeste. Estas áreas são denominadas de brejos e consideradas disjunções da Mata Atlântica (Fonseca \& Brazil, 2004).

Nas serras e chapadas acima de 600 metros, distantes do litoral, ocorrem fisionomias florestais caducifólias denominadas localmente de Florestas Secas. A maioria dos estudos na região tem priorizado a cobertura vegetal da depressão sertaneja que apresenta fisionomia predominantemente arbustiva e é denominada regionalmente de caatinga. Conseqüentemente há poucos estudos sobre floresta seca na região e, portanto, não se sabe qual conjunto florístico constitui esta floresta. Conforme a literatura, a composição e riqueza de famílias encontradas corroboram com o esperado para florestas secas neotropicais, exceto Bignoniaceae e Rubiaceae que não estão entre as mais abundantes neste estudo. Diferentemente da Caatinga, as Florestas Secas do Nordeste Brasileiro possuem maior proporção de plantas lenhosas do que de plantas herbáceas (Lima el al., 2004).

\subsection{1 - Nomenclatura dos diferentes tipos vegetacionais}

Todos os fatores mencionados condicionam diferentes tipos de vegetação, que infelizmente tem recebido diferentes nomes exigindo, portanto, alguns comentários. De modo geral, ocorre vegetação de cerrado no topo dos tabuleiros, florestas úmidas perenifólias ou semideciduas nos topos das serra (como os brejos de Pernambuco) e florestas secas ou formações de caatinga arbórea nas encostas e nos inselbergs (Prado, 2003).

$\mathrm{Na}$ Bahia ocorrem florestas do tipo matas ciliares, matas de encosta, matas de planalto e matas de grotão, principalmente na região da Chapada Diamantina. As matas de planalto são florestas estacionais semideciduais. A mata de grotão ocorre quando há o encontro de duas elevações, ás vezes sem vegetação densa. Geralmente a região intermediária torna-se mais úmida, desenvolvendo vegetação densa de matas de grotão (Prado, 2003).

Em termos fisionômicos, o tipo dominante nas serras é a floresta densa, também chamada de floresta serrana ou brejo de altitude, associada à floresta aberta nas escarpas médias e inferiores voltadas para a direção dos ventos, à vegetação caducifólia espinhosa nas escapas de sotavento e, eventualmente, vegetação rupícula em locais com afloramentos de rocha. A distinção físionômica, 
floristica e ambiental entre a floresta serrana e a vegetação caducifólia espinhosa é clara, mas a transição entre elas não é abrupta, encontrando-se diferentes fisionomias e floras dependendo da altitude e exposição do relevo. Quando ocorre vegetação caducifólia não-espinhosa, denomina-se "carrasco" (Rodal \& Nascimento, 2002). Informalmente, carrasco é considerado caatinga em área pedregosa. Segundo o IBGE (1977) a floresta caducifólia não-espinhosa corresponde a uma formação mais seca que a floresta subcaducifólia tropical, que contribui com seus componentes naquela floresta juntamente com a caatinga.

Outra terminologia que, às vezes, gera confusões refere-se aos termos agreste e sertão. $O$ agreste é o nome dado à faixa estreita de vegetação que se estende entre os limites da vegetação atlântica a leste, com abundância de florestas e os interiores mais secos a oeste. Entretanto, na Bahia essa região é denominada "mata de cipó", que não possui semelhança com a mata de cipó presente em Minas Gerais. A vegetação é geralmente decidua e espinhosa (Prado, 2003). Entretanto, algumas vezes prevalece a terminologia utilizada pelo IBGE (1977), que considera que a floresta caducifólia não-espinhosa teria poucas epífitas e muitas lianas, fazendo com que seja chamada de mata de cipó.

Entre as comunidades de caatinga definidas por Prado (2003), as que possuem relevância para este trabalho são: floresta de caatinga alta, que ocorre no centro-sul da Bahia, sobre rochas calcárias do Grupo Bambuí ou rochas cristalinas do Pré-Cambriano; floresta de caatinga baixa que ocorre no centro-norte da Bahia, caatinga arbustiva nas áreas mais secas do vale do rio São Francisco principalmente sobre rochas cristalinas e caatinga arbustiva aberta situada em pequenas áreas restritas e espalhadas com solos ricos em cascalho principalmente sobre rochas metamórficas do Pré-Cambriano. Rocha et al. (2004) acrescentam que em encostas de planaltos carstificados encontra-se caatinga arbórea aberta.

\section{2 .2 - Ecorregiões do Bioma Caatinga}

No bioma Caatinga a vegetação está submetida à deficiência hídrica sazonal, agravada nos anos de seca. Apresenta surpreendente diversidade de ambientes, proporcionadas por mosaico de tipos de vegetação, em geral caducifólia, xerófila e, por vezes, espinhosa, variando com o mosaico de solos e a disponibilidade de água. A vegetação considerada mais típica de caatinga encontra-se nas depressões sertanejas: uma ao norte e outra ao sul do bioma, separadas por uma série de serras que constituem barreira geográfica para diversas espécies. Mas os diferentes tipos de caatinga estendem-se para regiões mais altas e de relevo variado, incluindo a caatinga arbustiva arbórea, a mata seca e a mata úmida, o carrasco e as formações abertas com domínio de cactáceas e bromeliáceas, entre outras. 


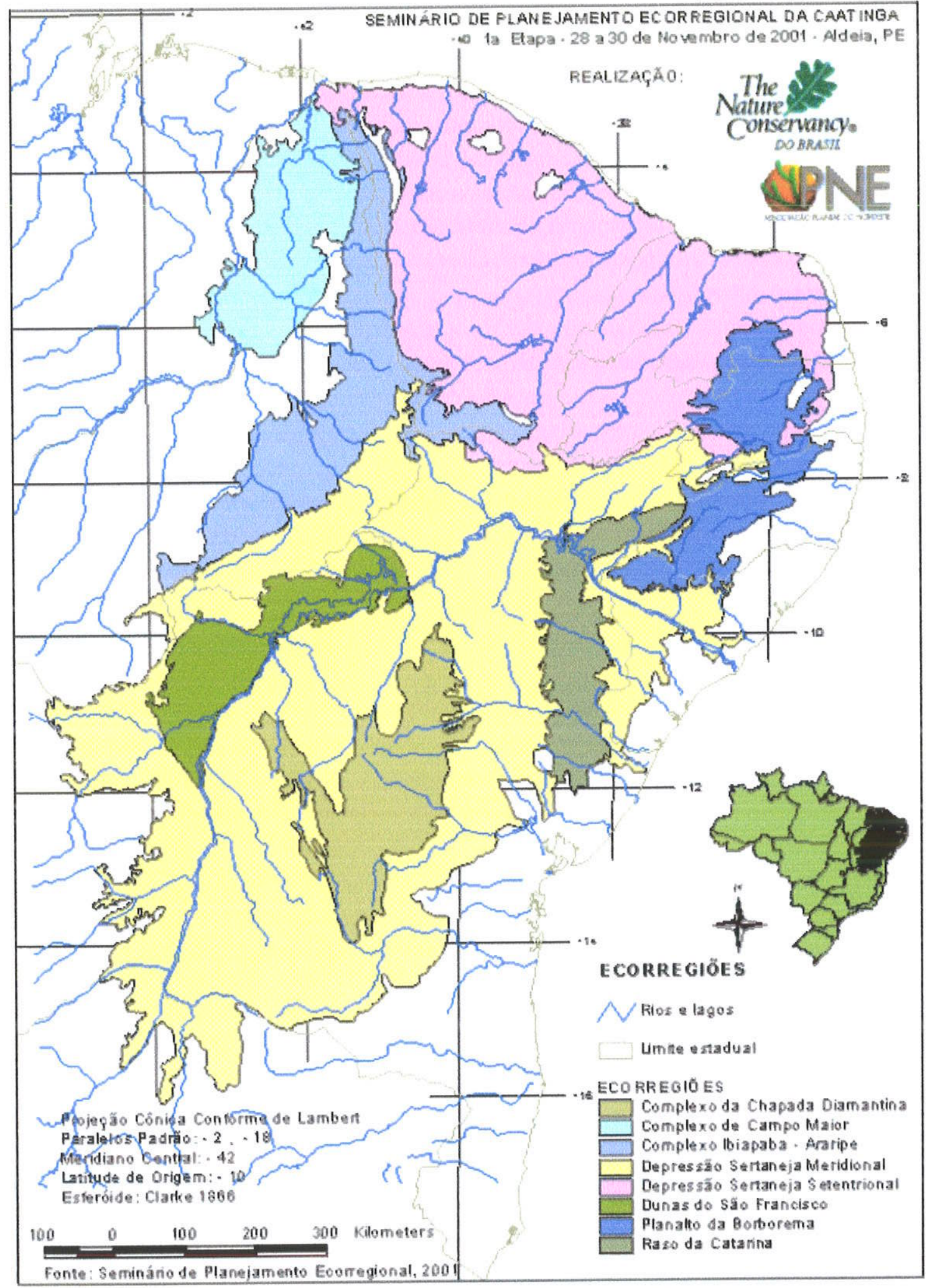

Figura 10 - Mapa das diferentes ecorregiões do Bioma Caatinga proposto no Seminário de Planejamento Ecorregional, 2001. 
Oito ecorregiões são identificadas: Complexo Chapada Diamantina, Complexo Campo Maior, Complexo IbiapabamAraripe, Depressão Sertaneja Meridional, Depressão Sertaneja Setentrional, Dunas do São Francisco, Planalto da Borborema e Raso da Catarina conforme indica a figura 10 .

Apenas o Complexo Chapada Diamantina, a Depressão Sertaneja Meriodional, Dunas do São Francisco e Raso da Catarina ocorrem dentro dos limites do Estado da Bahia. Para cada uma destas há um esquema demonstrando sua localização.

\section{Complexo Chapada Diamantina}

Localizado na parte centro-sul da região da Caatinga, alongado no sentido N-S e em forma de "Y", seguindo o alinhamento do divisor de águas da Chapada Diamantina.

O Complexo é totalmente circundado pela ecorregião da Depressão Sertaneja Meridional. Os limites são definidos principalmente pelas mudanças de relevo, altitude e tipo de solo.

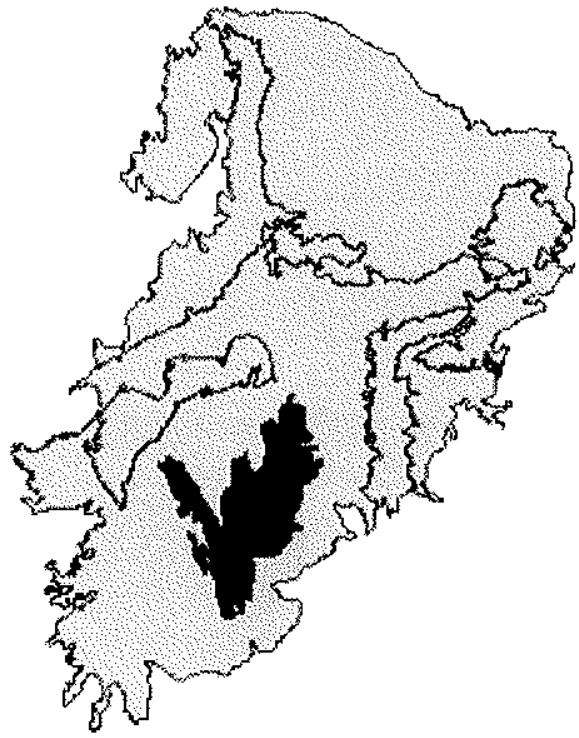

Nesta ecorregião estão presentes os Maciços e Serras Altas; Superfícies Retrabalhadas; Chapada Diamantina; e Superfícies Cársticas.

A Chapada Diamantina é a parte setentrional da Cadeia do Espinhaço que se inicia na Serra do Ouro Branco, município de Ouro Preto (MG) $-21^{\circ} 21^{\prime} \mathrm{S}-\mathrm{e}$ estende-se rumo norte, por cerca de 100 quilômetros, até a Serra de Jacobina na Bahia $-10^{\circ} 00^{\prime} \mathrm{S}$, com largura variando entre 50 e 100 quilômetros, entre $40^{\circ} 10^{`} \mathrm{e}$ 4430`O (Giulietti et al. 1997).

Ocupa posição central no Estado da Bahia, com cerca de 15.000 quilômetros quadrados e 58 municípios. Nesta região são encontrados diversos tipos de vegetação, com a presença de cerrados e campos rupestres nas áreas mais altas (acima de 1.000 metros de altitude), e caatingas nas áreas de altitudes menos elevadas. Tal situação é devida à associação de montanhas, cujas altitudes variam desde 900 até 2000 metros acima do nível do mar (Pico do Barbado, Abaíra) e terras mais baixas no entorno. A Chapada no seu extremo sul, divide-se em duas cadeias independentes, as Serras do Rio de Contas e Serra das Almas a oeste e a Serra do Sincorá a leste. Entre as Serras do Sincorá e do Rio de Contas encontra-se um platô arenoso de relevo ondulado, geralmente entre 1100 e 1200 metros conhecido como Campos Gerais. (Rocha et al., 2004). 
A diferenciação de campos rupestres e cerrado é condicionado ao tipo de solo: em afloramentos rochosos, predominam os campos rupestres e nos locais de solo mais arenoso, predomina o cerrado.

\section{Depressão Sertaneja Meridional}

Ocupa a maior parte do centro e sul da Caatinga, limita-se com todas as ouiras ecorregiões exceto a do Complexo de Campo Maior, fora do Estado da Bahia. A norte e noroeste encontra uma barreira de altitude (Serra dos Cariris e Complexo Ibiapaba - Araripe). A oeste limita-se com o início do Planalto Central, onde começa o cerrado. A sul e a leste encontra modificações de solo e precipitação, fazendo limite com o cerrado de Minas Gerais e a Zona da Mata da Bahia, Sergipe e Alagoas. No canto nordeste existe uma barreira de altitude com o início do Planalto da Borborema.

Três ecorregiões são quase inteiramente (Raso

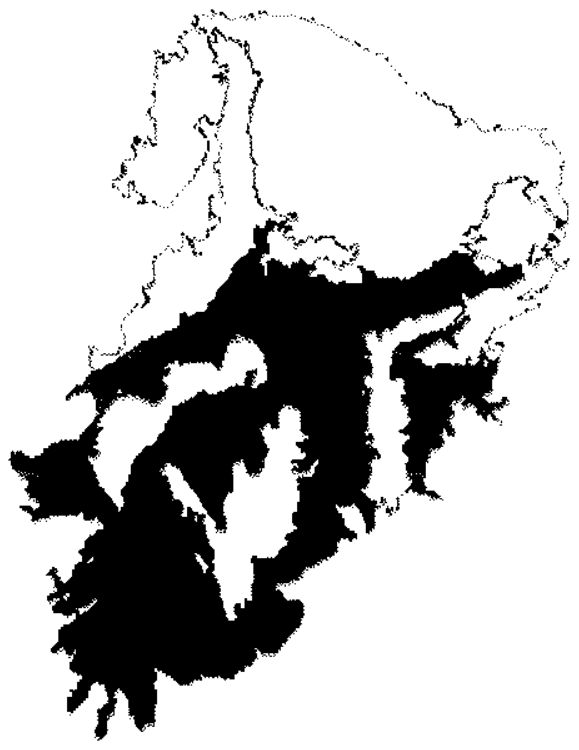
da Catarina) ou inteiramente (Dunas do São Francisco e Complexo da Chapada Diamantina) circundadas pela Depressão Sertaneja Meridional.

Constitui a paisagem mais típica do semi-árido nordestino: extensas planícies baixas, de relevo predominante suave-ondulado, com elevações residuais disseminadas na paisagem. Esta ecorregião, entretanto, apresenta maior diversidade de relevo em sua metade sul, com relevo acidentado e extensos platôs no entorno da Chapada Diamantina (BA), inclusive áreas de planalto na região de Vitória da

Conquista e ao sul de Maracás. Ocorrem ainda grandes extensões de áreas que têm sofrido intenso intemperismo, principalmente na parte sudeste da ecorregião (a leste da Chapada Diamantina), com relevo dissecado e vales profundos. A altitude varia de 100 a 500 metros, com algumas áreas de 500 a 800 metros, contendo picos acima de 800 metros

O clima da ecorregião é predominantemente quente, com dois periodos chuvosos distintos principais - de outubro a abril nas áreas de sertão (inclusive regiões cársticas) e de janeiro a junho nas áreas de agreste. A precipitação média anual varia de 500 a 800 milímetros, sendo que nas áreas mais altas do sul da ecorregião pode ultrapassar 1.000 milímetros por ano. 


\section{Dunas de São Francisco}

Ecorregião da parte centro-oeste da região de Caatinga, inteiramente circundada pela ecorregião da Depressão Sertaneja Meridional. Respeita os limites naturais da região das dunas de areias quartzosas, que são dispostas descontinuamente, conectadas apenas por trechos de solos arenosos sem dunas, terminando onde os solos se modificam a norte e oeste para latossolos. $\mathrm{O}$ limite diagonal sul é quase todo definido pelo rio São Francisco, e a sudoeste limita com a Serra do

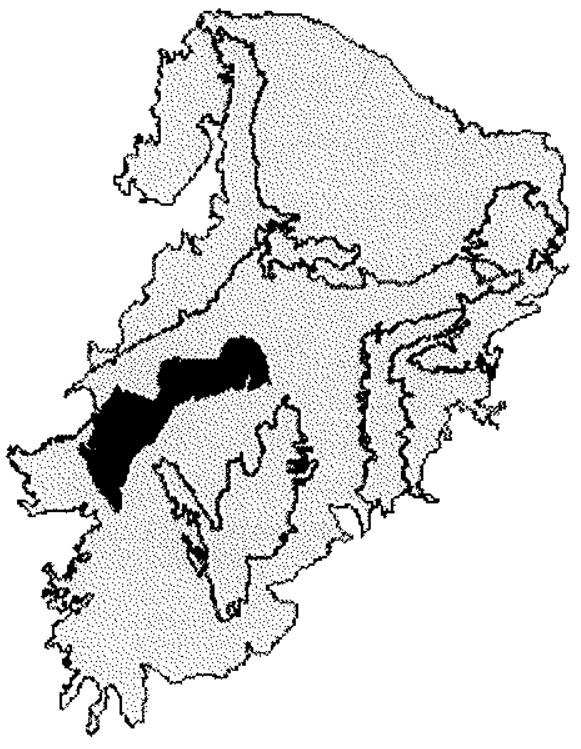

Estreito na Bahia (limite de altitude). A maior parte da ecorregião fica a oeste do rio São Francisco.

As dunas são formadas por extensos depósitos eólicos, podendo ultrapassar 50 metros de altura. Os solos são arenosos e profundos, de areias quartzosas, com fertilidade muito baixa. Nas depressões interdunares existem veredas. Os únicos recursos hídricos provêm das escassas chuvas e dos riachos efêmeros que nascem na região. A altitude varia de 450500 metros na área das dunas propriamente ditas, e de 150-700 metros no resto da ecorregião.

\section{3 - Descrição do material fossilífero e interpretações taxonômicas}

O material foi esquematizado e sua nervação descrita segundo os critérios de Hickey (1973) com modificações propostas por Pole (1991). Serão considerados dados lineares como comprimento do limbo (L), largura máxima (l) e a altura da largura máxima (h) a partir da base. Esses três dados fornecem uma relação de delgadeza $(\mathrm{L} / \mathrm{l})$ e uma relação de forma $(\mathrm{h} / \mathrm{L}$ X 100) que permitem a determinação do formato foliar de forma métrica, seguindo os parâmetros de Mouton (1966).

Ao se considerar a relação de delgadeza (L/l), será adotado o padrão de Mouton (1976), que quantifica e delimita as formas oblongas, elípticas e ovais, considerando a relação de forma $(\mathrm{h} / \mathrm{L} \mathrm{x}$ 100) no intervalo entre 40 e $60 \%$ como forma elíptica. Desse modo, não há avaliação subjetiva.

Quando possível, mede-se o ângulo de afilamento do limbo no ápice $(\alpha)$, que corresponde ao ângulo entre as tangentes aos arcos definidos na formação de ápices atenuados (Figura 11). 


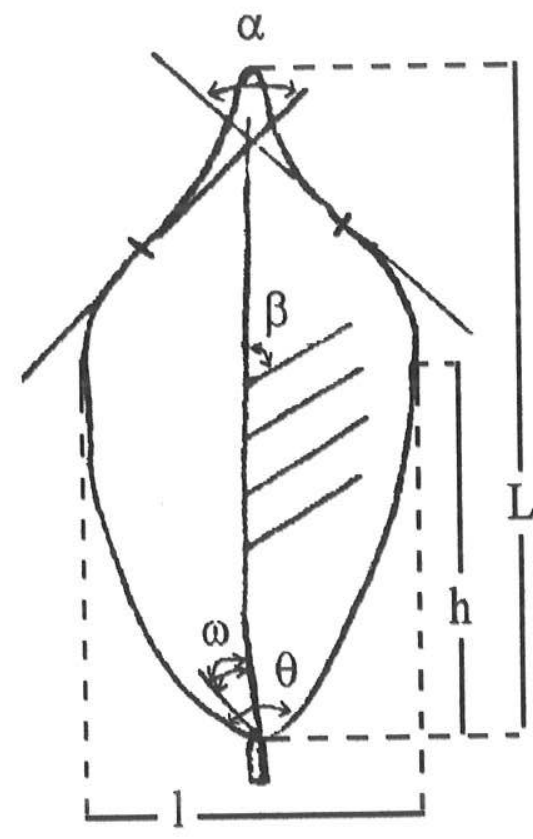

Figura 11 - Representação das principais medidas lineares e angulares utilizadas.

As medidas de área da lâmina foliar/foliolar estão sendo realizadas pelo método da planimetria por contagem de pontos em grade de $0,5 \mathrm{~cm}$, fornecendo boa precisão para a coleta de dados paleoclimáticos. A figura 12 ilustra o processo. Consideram-se apenas os pontos que estiverem dentro do limbo foliar, mesmo que ele esteja muito próximo da margem para fora ou para dentro, pois é dessa forma que se consegue estimar a área do limbo foliar levando-se em conta $o$ arredondamento de sua forma. Desse modo, os pontos amarelos não são considerados. Essa metodologia substitui a que calculava dois terços da área do retângulo delimitado pelo limbo foliar. No caso de folhas fragmentadas, como a ilustrada, pode-se tentar estimar o contorno original, mas a estimativa é menos precisa.
A maioria das medidas angulares refere-se aos ângulos de emergência da nervação secundária por ser este o caráter mais comumente preservado nos espécimes. Esses ângulos são designados pela letra grega beta $(\beta)$, de modo que $\beta p$ representa os ângulos do terço proximal do limbo, $\beta \mathrm{m}$ do terço médio e $\beta \mathrm{d}$ os ângulos do terço distal.

Também considera-se o ângulo de expansão do limbo foliar na base $(\theta)$ e o de emergência da venação terciária exigido nas determinações de padrões utilizados por Hickey (1973).

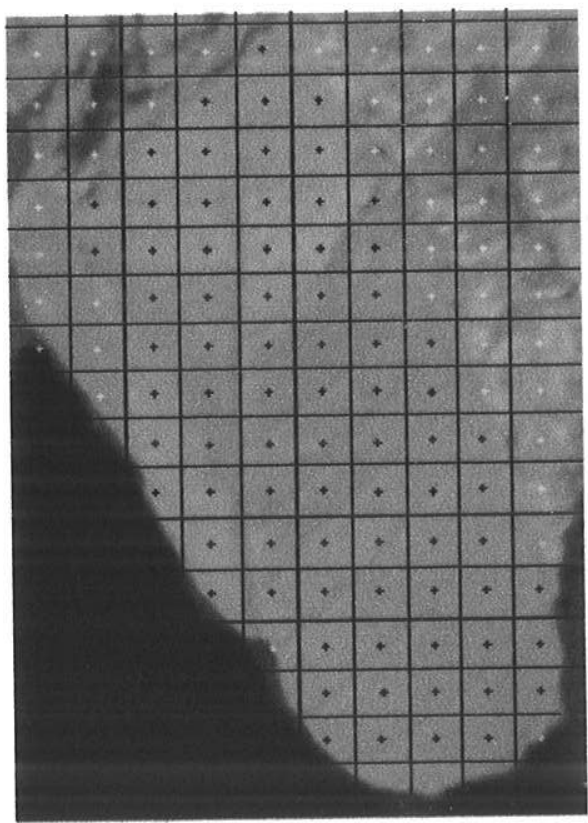

Figura 12 - Representação gráfica do processo de planimetria por contagem de pontos. 
Devido às características do tufo calcário e a importância de obtenção dos dados apresentados, foi preciso coletar grandes blocos para melhor conhecimento da gènese do depósito assim como para a observação adequada dos macrofitofósseis, uma vez que eles não se encontram no mesmo plano de acamamento, estando geralmente, parcialmente, dobrados.

Para a análise sistemática consultou-se a literatura paleobotânica referente a Área Neotropical e a literatura botânica específica para cada categoria taxonômica. Entretanto, a principal fonte de consulta refere-se ao material do herbário ALCB, com espécimes presentes nas diversas vegetações da Bahia. Essa comparação é muito importante visto que trabalhos anteriores que descreveram assembléias fósseis no nordeste brasileiro, basearam suas comparações nos acervos de herbários no eixo Rio-São Paulo, principalmente Rio de Janeiro. A vegetação predominante nessa região, referida nos herbários acima, corresponde ao Complexo Vegetacional Atlântico, conseqüentemente, todos esses depósitos foram reconhecidos como de matas ciliares. A comparação com espécimes ocorrentes na Bahia, pelo exame do ALCB aumenta a confiabilidade do processo de identificação.

Para facilitar a análise de todos os morfotipos foliares da assembléia fóssil de Campo Formoso, com todos os espécimes de dicotiledôneas do herbário ALCB, estabeleceram-se critérios juntados em uma espécie de chave dicotômica para o reconhecimento dos morfotipos. Esses critérios estão relacionados com as principais características observadas nas folhas e que são de fácil identificação no registro fossilifero.

Entre os critérios encontram-se três tipos básicos de padrão de nervação (actinódromo, broquidódromo e eucampdódromo), assimetria da folha, presença de dentes, disposição alterna ou oposta das nervuras secundárias, espessura da nervura primária, presença de textura coriácea, presença de nervuras percorrentes, externas e/ou intersecundárias e classes de tamanho. Durante as pesquisas do herbário foram também observadas as formas do ápice e da base e do próprio limbo foliar, características necessárias a elaboração da análise multivariada para inferências climáticas.

Alguns parâmetros estão ilustrados no capítulo 6 , resultados taxonômicos, para melhor caracterização dos $t a x a$, como os padrões de nervação, presença de dentes, nervuras percorrentes, externas e secundárias. Os parâmetros da análise multivariada serão comentados mais adiante.

Com base nos dados do herbário, foram elaboradas listas taxonômicas de todas as espécies que exibiram uma das características mencionadas acima, para constituição de parâmetros de comparação e identificação dos morfotipos e suas aplicações nas deduções paleoclimáticas. Através dessas listas taxonômicas pode-se observar a freqüência de ocorrência dessas características na flora baiana como um todo, mas principalmente sua ocorrência dentro de cada família. Familias representadas apenas por uma espécie, possivelmente são pouco significativas, podendo conduzir a 
erros de identificação. A relação de todas as familias analisadas, seus respectivos gêneros presentes e o numero de espécies observadas pode ser consultada no Anexo 1.

Inicialmente examinadas por familias, de acordo com a disposição dos armários, essas fotos precisaram ser renomeadas para que pudessem ser agrupadas. Após a listagem de cada foto (espécie, localidade, tipo de vegetação, hábito e número da foto), elas foram agrupadas segundo dois critérios: localidades e características.

A distribuição das fotos por localidade tem por finalidade estabelecer um padrão fisionômico dos tipos de vegetações da Bahia, visto que foi observado, durante os trabalhos do herbário, que as espécies de Caatinga năo seguem o padrão geral internacional, utilizado nos trabalhos fisionômicos de Wolfe (1993). Geralmente as folhas de uma determinada espécie são gradativamente maiores à medida que habitam vegetações mais fechadas, porque é necessária maior área foliar para a fotossíntese sob menor luminosidade. Este padrão não foi observado nos exemplares do herbário, de modo que se optou por análise fisionòmica de cada localidade que contivesse mais de 20 espécies, documentadas fotograficamente para que se pudesse comparar com os espécimes fósseis de Campo Formoso. Essa análise não foi inicialmente prevista, uma vez que seria utilizado o padrão internacional, contudo, a análise realizada foi mais acurada.

O agrupamento de fotos por características de fato corresponde a uma organização racional, visto que todas as fotos de cada espécie (independente da quantidade de espécimes) foram copiadas para pastas representando características determinantes dos morfotipos organizados para o herbário.

A grande quantidade de fotos separadas por caracteristicas fe $z$ com que se elaborasse um "álbum de fotos" com as folhas que melhor representavam a característica em questão. Num segundo momento, após o término do doutoramento, tem-se a intenção de elaborar metodologia auxiliar ao processo de identificação taxonômica a partir do registro foliar com um banco de dados e chave dicotômica para otimizar o acesso ao banco.

Após o reconhecimento taxonômico dos diferentes morfotipos, elaborou-se uma lista florística da assembléia fóssil total e listas para cada afloramento para demais interpretações, visando reconhecer a distribuição preferencial das espécies, famílias mais diversificadas e comparações com listas floristicas desenvolvidas em trabalhos fitosociológicos publicados.

4.4 - Análise físionômica e suas interpretações

Duas metodologias foram aplicadas para as interpretações paleoclimáticas através de tafofloras, de acordo com a sugestão de Dolph \& Dilcher (1979). 
A primeira metodologia refere-se à análise das preferências climáticas do táxon vivente mais próximo, quando todos os laxa fósseis săo identificados a gêneros modernos. Envolve o tratamento estatístico na identificação e delimitação dos taxa ocorrentes; o uso de conhecimentos sobre preferências ecológicas e sociológicas (tolerância) dos taxa atuais em situações pretéritas e identificação e estabelecimento de afinidades do espectro polinico. Baseando-se nos habitats preferenciais do conjunto, estimam-se a temperatura média anual. Esse primeiro mètodo corresponde ao utilizado por Axerold \& Bailey (1969).

O segundo método, desenvolvido principalmente por Wolfe \& Hopkins (1967), emprega a fisionomia foliar. Oito caracteres são admitidos como correlacionados com o clima: tamanho (Raunkiaer, 1934); tipo de margem (Bailey \& Sinnott, 1915; 1916); ápices acuminados (drip-tips, Wolfe, 1971); organização foliar composta x simples (Bailey \& Sinnott, 1916); padrão fundamental de venação (Bailey \& Sinnott, 1916); densidade de venação (Wolfe, 1971); textura (Wolfe, 1971); forma do ápice e da base (Howard, 1969).

Em todas as metodologias utilizam-se dados complementares e independentes, fornecidos pela sedimentologia: ambientes deposicionais e história geológica da região, de modo a determinar as causas e os efeitos.

Além da composição florística, uma pesquisa paleobotânica deve tentar determinar que tipo de vegetação a tafoflora representa. A vegetação baseia-se na fisionomia, enquanto que a flora diz respeito a composição florística, de modo que as flotestas da Amazônia e da Malásia, a despeito das diferenças taxonômicas, ambas são representantes da denominada Floresta Tropical Chuvosa (Tropical Rain Forest). Associações florísticas vizinhas, submetidas a climas dissimilares, possuem características físicas diferentes, embora possam ter muitos taxa em comum. Áreas submetidas a altas temperaturas médias anuais e altas precipitações possuem folhas de margem inteira, largas, coriáceas, com alta porcentagem de ápices acuminados (drip-tips) e numero moderado de bases cordadas associadas à venação palmada e pulvínio (Wolfe, 1978).

As análises florísticas, por suas características qualitativas, estão sujeitas a consideráveis variações, que muitas vezes comprometem as interpretações climáticas. Entretanto, na análise de fisionomia foliar, com uso de métodos quantitativos, as estimativas são mais confiáveis.

A partir dos trabalhos de Wolfe $(1971,1978,1979,1980,1985,1990,1993,1994)$ tornou-se viável a análise paleoclimática pela fisionomia foliar. Seus trabalhos estabeleceram relações entre as vegetações e suas inferências paleoclimáticas, além da introdução de métodos estatísticos apropriados para interpretações mais precisa dos dados. O método, independentemente de estudos taxonômicos, é essencialmente quantitativo. A composição florística é utilizada apenas para complementar e corroborar os parâmetros inferidos 
Como ressalta Greenwood (1992), as análises fisionomicas nas macrofloras do Neocretáceo e Terciário, têm sido usadas para interpretaçoes climáticas (Wolfe, 1971, 1985, 1990; Dolph \& Dilcher, 1980; Christophel \& Greenwood, 1989). Assume-se que a assinatura climática presente na fisionomia foliar pode ser detectada em populações fósseis com minima distorção (Wolfe, 1979 ; Burnham, 1989; Christophel \& Greenwood, 1989)

Aplicando-se a metodologia estatística de Wolfe (1993) para obtenção de parâmetros climáticos a partir de assembléias foliares, foram elaboradas planilhas de dados para cada uma das tafofloras, calculando-se, posteriormente, as porcentagens de ocorrência de cada um dos 29 caracteres morfológicos considerados. É importante ressaltar que para análise multivariada, consideram-se apenas os aspectos físionômicos de cada espécie, independente do número de espécimes existentes, assim como de seu posicionamento taxonòmico.

Os critérios fisionômicos utilizados por Wolfe (1993) incluem, tipo de margem apresentado pela folha/folíolo (lobado ou não, denteado ou não, regularidade, proximidade e formato dos dentes), a área foliar/foliolar, o tipo de ápice (emarginado, arredondado, agudo ou atenuado), o tipo de base (cordada, arredondada ou aguda), relação de delgadeza (L/L: $<1: 1 ; 1-2: 1 ; 2-3: 1 ; 3-4: 1$ e $>$ $4: 1)$ e o formato foliar/foliolar (obovado, elíptico ou ovado).

Espécies apresentando dois tipos de ápices, por exemplo, terão o score total (1) dividido entre cada variável desse caráter $(0,5)$, de modo a representar o comportamento fisionômico da espécie.

De acordo com a metodologia elaborada por Cristalli (1997), associam-se os limites explicitados por Raunkiaer (1934), os desenhos de Wolfe (1993) e o método de planimetria de pontos, estabelecendo-se os seguintes limites:

\begin{tabular}{|c|l|l|}
\hline $\begin{array}{l}\text { Classes utilizadas na análise } \\
\text { paleoclimática. }\end{array}$ & $\begin{array}{l}\text { Limites de área obtidos por } \\
\text { planimetria de pontos. }\end{array}$ & $\begin{array}{l}\text { Classes de Raunkiaer (1934) } \\
\text { equivalentes. }\end{array}$ \\
\hline lepto I & de 0 a $0,25 \mathrm{~cm}^{2}$ & leptófila \\
\hline lepto II & de 0,25 a $2,25 \mathrm{~cm}^{2}$ & nanófila \\
\hline micro I & de 2,25 a $4,75 \mathrm{~cm}^{2}$ & micrófila pequena \\
\hline micro II & de 4,75 a $20,25 \mathrm{~cm}^{2}$ & micrófila média e grande \\
\hline micro III & de 20,25 a $45,00 \mathrm{~cm}^{2}$ & classe notófila - Webb, 1959 \\
\hline meso I & de 45,00 a $87,50 \mathrm{~cm}^{2}$ & mesófila média \\
\hline meso II & área maior que $87,50 \mathrm{~cm}^{2}$ & mesófila grande e/ou maior \\
\hline
\end{tabular}


Os paràmetros tipo de ápice e tipo de base, sem finalidade descritiva, evidenciam as formas através das quais os vegetais reagem a fatores climáticos, principalmente precipitação e umidade. Assim, ápices atenuados, por exemplo, indicam altas precipitações.

A relação de delgadeza, isto é, a relação entre o comprimento e a largura máxima da folha, relaciona-se com a velocidade de crescimento dos meristemas foliares. Além do componente hereditário, esse crescimento mostra-se influenciado por fatores climáticos. O formato foliar tem comportamento semelhante.

Após o trabalho de Wolfe (1993), alguns autores procuram melhor identificar parâmetros fisionômicos que auxiliem a estimativa de parâmetros ambientais mais específicos como altitude. Enquanto o clima propriamente dito é mais bem refletido no tamanho e forma das folhas, a altitude reflete-se na lobação da folha, presença e/ou variação de dentes e no formato do ápice foliar (Forest et al., 1999). Outros trabalhos retrocedem às análises univariadas por considerá-las mais precisas, com maior grau de significância no procedimento estatístico. A principal alegação refere-se ao fato do CLAMP ter sido desenvolvido baseando-se apenas em florestas da América do Norte e poucas localidades tropicais. América do Sul e Europa, por exemplo, estão excluidas. Florestas muito úmidas, por exemplo, podem ter folhas muito menores que locais mais secos na mesma região (Wilf et al, 1998)

Por outro lado, novos trabalhos também procuram melhorar as análises baseadas no comportamento climático do taxon vivente mais afim, procurando torná-las mais confiáveis. A grande vantagem desta metodologia corresponde à determinação de intervalos climáticos sob os quais a vegetação poderia se submeter, incluindo dados sobre os limites de incerteza derivados desta análise. Além disso, pode ser usado para qualquer tipo de assembléia e não apenas para foliares (Mosbrugger \& Utescher, 1997).

\section{5 - Tufos ativos de Bonito, MS: mecanismos atuais de formação de tufos calcários}

Na área de Bonito, MS, ocorrem tufos em processo de formação. A visita a esta área teve por finalidade compreender os processos de formação dos tufos para melhor avaliar os tufos fósseis de Campo Formoso, BA. Os tufos da Serra da Bodoquena, região de Bonito, MS são formados pela deposição de carbonatos, por ação biológica em águas ricas em bicarbonato (Boggiani \& Coimbra 1995) originados pela dissolução dos calcários neoproterozóicos do Grupo Corumbá, em áreas cársticas. Dentre os tufos da Serra da Bodoquena, Boggiani et al. (2000) reconhecem dois tipos principais: os de represas e cachoeiras e os micritos inconsolidadas (calcários pulverulentos). Além 
destes, encontraram-se outros dois tipos: os depósitos de leitos de rios e tufos do Planalto da Bodoquena. Assim caracterizam-se os quatro tipos de depositos:

1) Depósitos de leitos de rios: ocorrem praticamente em todos os rios da regiăo, cobrindo as margens, o leito e material rochoso e vegetal ao longo do rio. São encontrados tanto no Planalto da Bodoquena quanto nas planicies. Estão associados com os depósitos de represas e cachoeiras. No Rio Formoso foram observadas estruturas verticais, como domos e colunas, que se assemelham a bioconstruçōes, de tamanho centimétrico a decimétrico mais próximos à nascente, e métrico mais a jusante. O sedimento presente nos fundos dos rios é composto de partículas carbonáticas, gastrópodes (incrustados ou não), raros clastos terrígenos (incrustados ou não), e muitas carapaças incrustadas de algas caráceas, contendo pouco a nenhum material terrígeno. Estão associados aos depósitos de cachoeiras e represas, e em alguns casos observa-se sua continuidade com estes depósitos.

2) Represas e depósitos associados a cachoeiras e fluxos esporádicos de água junto aos rios (Boggiani et al. 2000). Estão presentes em praticamente todos os rios da região.

3) Tufos (micritos inconsolidados - calcários pulvurulentos) das planícies: representam depósitos antigos de tufo, associados a brejos em meandros de rios abandonados (Boggiani et al. 2000).

4) Tufos (micritos inconsolidados - calcários pulverulentos) do Planalto da Bodoquena: ocorrem principalmente na várzea do Rio Perdido e seus afluentes, na forma de micritos inconsolidados, pulverulentos e estratificados. Há presença comum de conchas de gastrópodes. São muito semelhantes aos micritos inconsolidados descritos por Boggiani et al. (2000), màs encontram-se afastados do leito atual do rio.

Vários aspectos da deposição atual dos dois primeiros tipos na região de Bonito, MS, foram fundamentais na compreensão dos processos genéticos que podem ser utilizados na interpretação dos depósitos fósseis de Campo Formoso, BA.

O Rio Sucuri nasce em um lago com suas águas extremamente transparentes, presença abundante de vegetações subaquáticas e aquáticas parcialmente submersas, nas margens do lago, e vegetação terrestre propriamente dita relativamente afastada do leito. Apesar da vegetação, não há depósitos calcários, possivelmente devido à pouca movimentação da água que dificultaria o escape de $\mathrm{CO}_{2}$.

Ao contrário do Rio Sucuri, o Rio Formoso contém vários tipos de tufos calcários. O rio não é transparente, de cor levemente esverdeada, embora ainda translúcida. A vegetação é relativamente fechada ao longo do rio, com monocotiledôneas em algumas porções da margem. Rio com várias quedas d'águas pequenas e fluxo forte, embora em alguns locais a água é apenas ligeiramente ondulada. Nas porções mais calmas, a vegetação de monocotiledôneas é mais ampla e a deposição 
de tufos ocorre nas margens do rio. Nas áreas de maior correnteza, a vegetação lenhosa, muitas vezes de porte arbóreo, ocorre bem próxima à margem.

Observa-se que em quedas d'águas maiores, há folhas recobertas de material carbonático que não estavam realmente sob o fluxo da água, mas estavam recebendo água de forma intermitente. A espessura do material carbonático era bem maior que a observada na maioria dos casos.

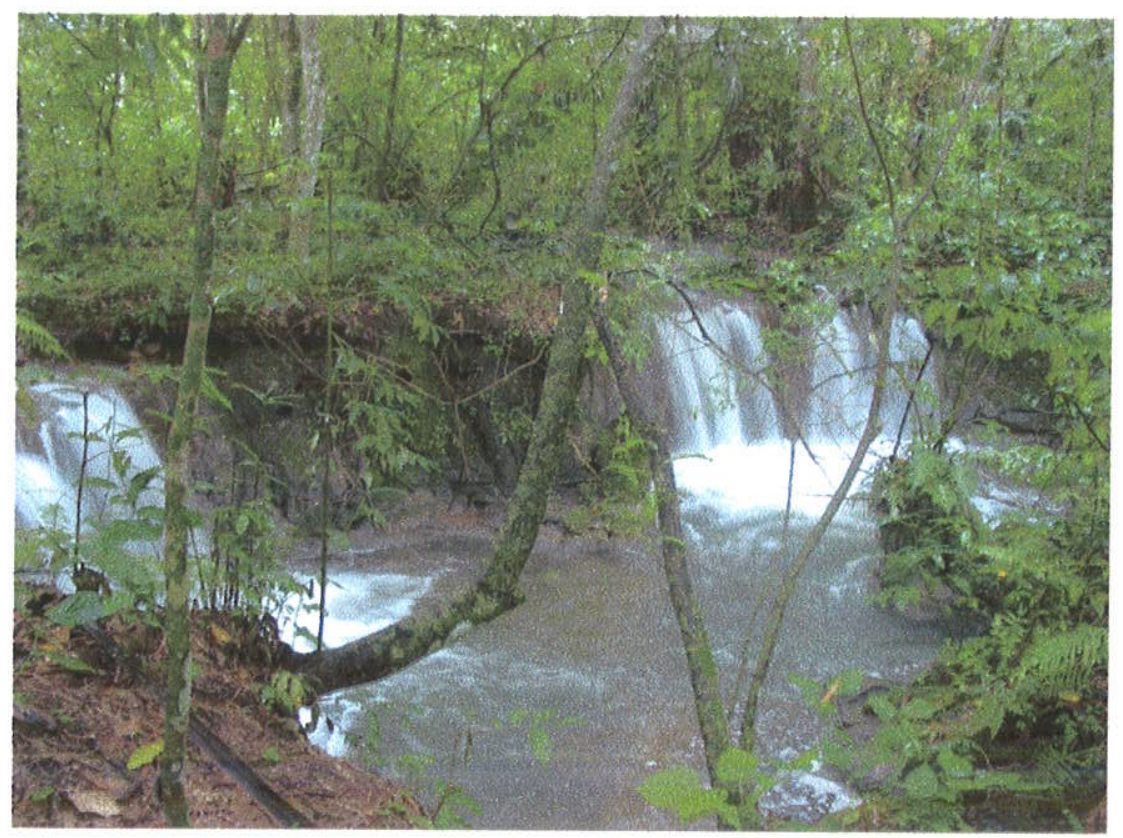

Figura 13 - Quedas d'água do Rio Formoso com fluxo forte e vegetação lenhosa adjacente

O tipo de depósito calcário mais similar aos de Campo Formoso, BA são os das represas e cachoeiras: Mesmo sob fluxo intenso, como no caso do Rio Aquidabam havia folhas amareladas aderidas às quedas d'água, possivelmente recém-chegadas ao rio. Nas margens das quedas d'água, encontram-se briófitas, monocotiledôneas ou mesmo vegetação lenhosa, que serão incorporadas ou não ao registro geológico durante a sedimentação do tufo.

$\mathrm{Na}$ base da cachoeira de Aquidabam, foi observado um depósito maciço e uniforme, bem semelhante ao encontrado em Campo Formoso, BA. Assim como nos demais rios, ocorrem grandes cavidades dentro dos depósitos. Essas cavidades tornam o depósito instável, rompendo-o eventualmente, proporcionando aparência final mais uniforme, como é o caso nos depósitos de tufos inativos.

Os depósitos de tufos fósseis foram analisados macroscopicamente, procurando-se padrões que facilitem a compreensão de ambientes deposicionais. Diferentes aspectos dos respectivos depósitos foram considerados como porosidade, grau de compactação e friabilidade, diferentes espessuras e características da deposição do carbonato, quantidade e posição das folhas, cavidades 
associadas on não às fothas, canais e canaliculos possivelmente de escoamento, estruturas tão diversas quanto "bolhas" e estruturas indicativas de retrabalhamento do calcário. Muitas dessas estruturas foram medidas, principalmente nos depósitos fósseis, já que a finalidade é estabelecer padrōes para a sua interpretação.

Nas compressões, as folhas estão preservadas, enquanto nas impressões há apenas indicios da presença foliar, com depressòes no lugar das nervuras.

A presença de fósseis, principalmente folhas, permitiu a inclusão dos atributos tafonômicos melhorando assim a interpretação da gênese do depósito mesmo considerando-se apenas as características macroscópicas.

Em relação à descrição tafonômica dos macrofitofósseis obedeceu-se a metodologia desenvolvida por Cristalli (1997), conforme descrito no item anterior. 


\section{5- Deposição de tufos calcarios e análise tafonômica}

\section{1 - Deposição dos tufos calcários}

Certos autores consideram o termo travertino em um sentido amplo, envolvendo tanto os de origem hidrotermal como os formados em condições meteóricas (Pentecost, 1993; Pentecost \& Viles, 1994). Outros autores restringem travertino para os originados em águas hidrotermais, reservando tufos calcários aos formados em condições meteóricas (Ford \& Pedley, 1996). Este conceito é aqui adotado.

O tufo calcário tipicamente contem restos vegetais macro e microscópicos, invertebrados e microorganismos. A presença de organismos multicelulares constitui a característica de mais fácil distinção entre tufo e travertino, já que o segundo praticamente não contêm restos an imais ou vegetais macroscópicos (Ford \& Pedley, 1996).

A deposição de tufos contraria ao que ocorre normalmente em regime fluvial. São sistemas de acreção e não de degradação. Normalmente formam fitohermas de pequena extensão, podendo ou não se comportar como verdadeiras barragens, de desenvolvimento transversal ao dos rios (Ford \& Pedley, 1996).

O processo de precipitação constitui um dos principais objetivos das pesquisas sobre tufos calcários, tendo em vista a sua aplicação em correlações climáticas. Aparentemente são produtos tanto da precipitação fisico-quimica inorgânica quanto biológica associada à colonização por biofilmes.

Em essência, a eliminação do $\mathrm{CO}_{2}$ rio abaixo aumenta o pH e causa a saturação de $\mathrm{Ca}$, conduzindo à precipitação principalmente nas quedas d’águas. A temperatura atmosférica e a remoção do $\mathrm{CO}_{2}$ pelo processo fotossintético não parecem ser importantes. Entretanto tecidos orgânicos, particularmente mucilagens de procariontes, aparentam ser ótimos sítios de nucleação calcítica. Supostamente a fotossíntese apenas alteraria o processo de calcificação. A biomineralização de eucariontes pode ser considerada como organicamente mediada, enquanto a de procariontes seria biologicamente induzida, representando, respectivamente, controles biológico e ambiental (Merz-Preiß \& Riding, 1999).

Embora as condições de deposição de tufos são variáveis nas latitudes temperadas (estação chuvosa associada com frio) e tropicais (estação chuvosa associada com calor), as estruturas dos tufos, seus organismos e suas tafonomias, podem ser comparados tendo em vista deduções de muitas das condições de sedimentação. 
As precipitações de depósitos de tufo em regiões de clima temperado ocorrem em fases quentes e úmidas em seqüencias glaciais e interglaciais. Em regiões subtropicais e semi-áridas, o máximo crescimento dos tufos é verificado em fases úmidas e geralmente frias (Ford \& Pedley, 1996).

No Brasil, a região na qual há deposição atual, Mato Grosso do Sul é mais frio e úmido que o Nordeste. Embora se deva comparar com ressalvas os mecanismos de deposição dos tufos na Europa, esta análise fornece subsidios para a compreensão dos mecanismos de deposição de tufos brasileiros.

No caso especifico em questão, a simples presença de depósito de tufo em pleno sertão baiano, é indicativa da existência, em tempos pretéritos, de clima mais úmido na região, pois há necessidade de água em abundância. A presença de grandes folhas nesses depósitos corresponde a outra evidência de umidade.

Goudie et al. (1993) sintetizaram as condições ideais para formação de tufos: a) condições climáticas favoráveis ao desenvolvimento de cobertura vegetal; b) evolução lenta das vertentes; c) disponibilidade de carbonatos; d) turbulência para promover a perda de $\mathrm{CO}_{2}$ da água. A alteração das condições acima pode interromper a deposição de tufos.

Baseado nas caracteristicas macroscópias de depósitos de tufo e na analogia com a classificação dos depósitos recentes, Janssen et al. (1999) diferenciaram três macrotipos dominantes.

1) Tufo granular consistindo de partículas menores que $1 \mathrm{~mm}$ a maiores que $5 \mathrm{~cm}$ de diâmetro. Estas partículas são principalmente componentes pequenos e pedaços de plantas e ramos incrustados que foram erodidos e redepositados em poças d'água atrás de cachoeiras, em condições calmas de deposição.

2) Tufo poroso porém duro consistindo de plantas incrustadas, musgos, ramos, folhas e raizes. Essa precipitação mostra características macroscópicas muito similares às precipitações em substratos orgânicos descritas para depósitos recentes.

3) Crostas carbonáticas laminadas consistindo de alternância de laminações de tufos de cianobactérias e laminações com aberturas lenticulares, similares às descritas nos depósitos recentes. A natureza dos substratos dessas crostas não é clara, aparentemente pode ser tanto orgânica, como restos de plantas, quanto inorgânica. Essas crostas são caracterizadas por laminações horizontais e sem musgos ou plantas, mas com diatomáceas. 
5.2. Aspectos tafonômicos associados a deposição vegretal

Em relação ao registro fóssil de vegetais, não é necessário haver morte do organismo, visto que as árvores perdem folhas freqüentemente. Em decorrência disto, as dicotiledôneas são mais freqüentes que a de monocotiledôneas, principalmente porque nestas últimas está ausente o processo de abscisão.

O principal agente responsável pelo transporte das folhas é o vento, mas alguns outros fatores influenciam na dispersão (Spicer, 1980): o peso das folhas influem nas velocidades e distâncias de transporte, as mais leves tendem a ser transportadas para mais longe. Os seus tamanhos não interferem tanto, se as folhas largas não encontrarem obstáculos no seu percurso, com maior frequência que as folhas menores (Ferguson, 1985). O fator determinante mais significativo parece ser o peso da folha por unidade de área, embora esta relação aparentemente não seja linear (Ferguson, 1985; Spicer, 1989; 1991). Atuam, de fato, no mínimo, dois processos de transporte relativamente distintos: a dispersão eólica inicial e o transporte que se segue após a queda no solo (Greenwood, 1991).

$\mathrm{Na}$ copa das árvores há folhas que estão expostas tanto à luz solar direta como à maior atuação do vento, sendo denominadas folhas de sol, geralmente menores que as folhas de sombra (Spicer, 1980; Ferguson, 1985). Deste contexto decorre a bem conhecida tendência de um depósito fossilifero possuir maior porcentagem das folhas de sol. Consequentemente estudos revelam que são encontradas folhas menores que o esperado numa proporção de três para dois (Greenwood, 1991). Entretanto, nem todos os vegetais possuem essa diferenciação em suas folhagens.

Uma vez no solo, o transporte das folhas é mais significativo em áreas de vegetação aberta. Mesmo que o vento não atue no transporte, promoverá desidratação com conseqüente redução do peso, que poderá chegar a $1 / 3$ do peso da folha verde. Folhas desidratadas podem sofrer longo transporte e vão se caracterizar pela aparência tauterizada (item c da figura 14, na página seguinte) (Ferguson, 1985). Em muitos casos, o processo de degradação nas folhagens pode iniciar-se até antes da abscição, como degradações por invertebrados.

As folhas de sol possuem as melhores chances de preservação pois possuem maior resistência à degradação que as folhas de sombra (Ferguson, 1985). As folhas sempre-verdes são coriáceas e ricas, tanto em lignina quanto em tanino. As folhas deciduas são papiráceas e contêm poucos fenólicos, sendo sujeitas à degradação mais rápida (Greenwood, 1991). 
A maior parte dos processos de fossilizaçăo progride em ambiente subaquoso. Folhas e outros restos vegetais podem cair diretamente na água ou serem transportados por inundaçăo. Nos climas tropicais, a maior potencialidade de fossilização é encontrada em restos vegetais que atingem diretamente um corpo d' água (Ferguson, 1985). Para melhores chances de fossilização, uma árvore de grande porte precisa estar, no máximo, cerca de 50 metros de um corpo d'água.

Grande parte do transporte das folhas pode ocorrer enquanto encontra-se flutuando no corpo aquoso. Durante o periodo de flutuação, as folhas também sofrem degradação. Após a lixiviação das substâncias hidrosolúveis, que varia de acordo com a espécie e a temperatura da água, segue-se a colonização por fungos e bactérias, que depende da oxigenação da água. Os fungos aparentemente são os mais importantes no processo de decaimento (Spicer, 1989) e a qualidade da água é fundamental nesse processo, principalmente no que se refere ao seu estado trófico.

Entre os outros fatores atuantes na degradação subaquática, incluem-se a natureza dos sedimentos e taxa de sedimentação, presença e freqüência de macrófitos e invertebrados (Rau, 1976; Ferguson, 1985; Spicer 1989). Como em qualquer processo biológico, o aumento da temperatura aumenta a taxa de degradação. Águas turbulentas causam danos mecânicos e águas calmas proporcionam diminuição da resistência e da elasticidade das folhas, ficando as mesmas suscetiveis às ondulações (Ferguson, 1985). A fragmentação mecânica é caracterizada por rasgos e quebras angulares na làmina foliar e pode ser diferenciada do dano causado biologicamente (Spicer, 1991). (Figura 14).
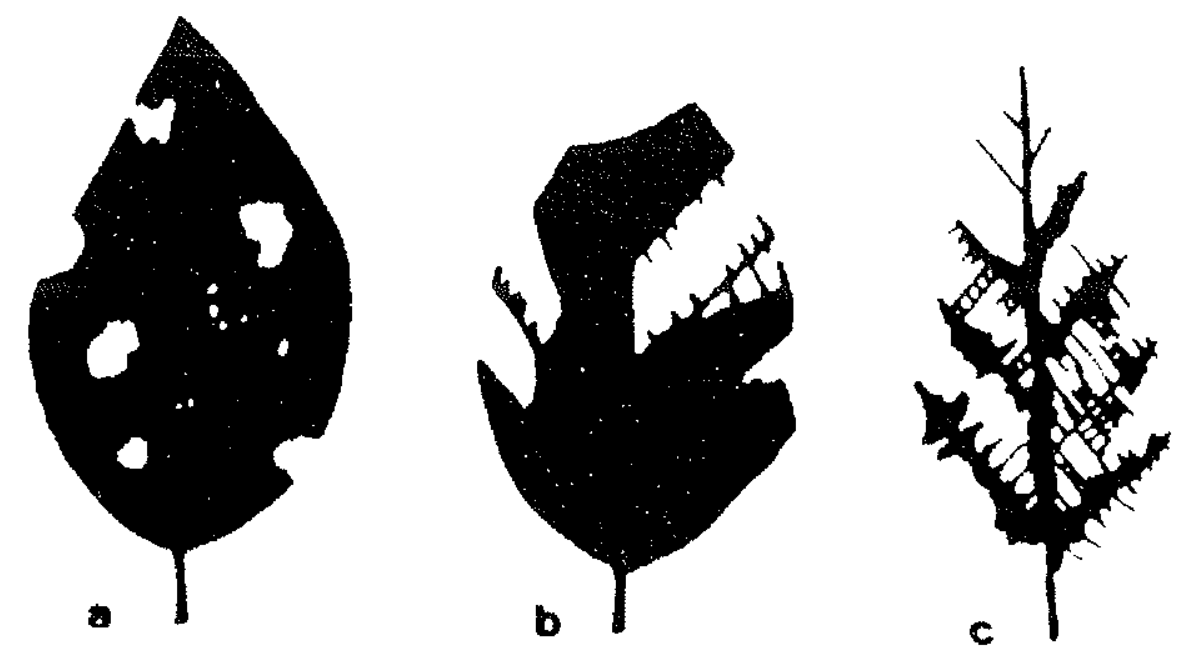

Figura 14 - Padrões típicos de degradação foliar: (a) degradação causada por invertebrados; (b) degradação causada por abrasão mecânica; (c) degradação causada por atividade microbiana. Extraido de Spicer (1989). 
Algumas características descritas

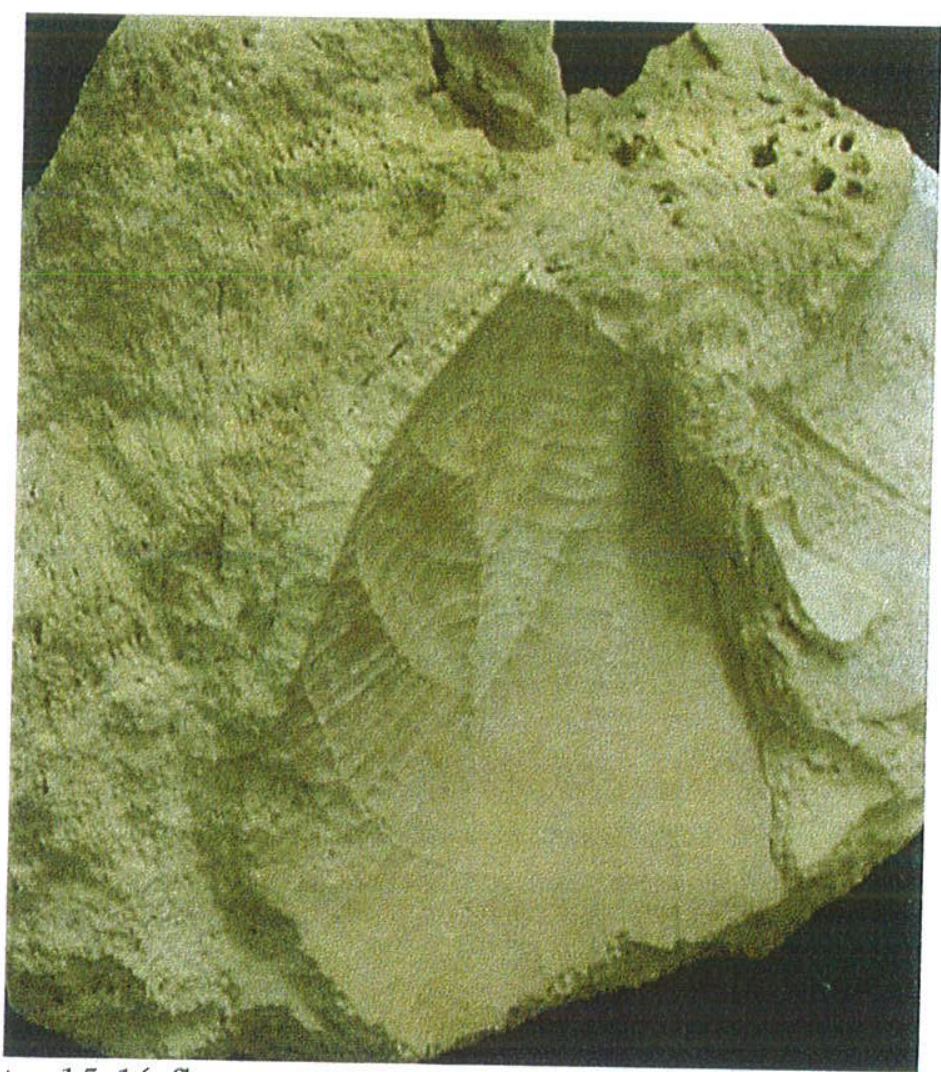

Figura 15 - Amostra 15-1(afloramento Faz. Bento) evidenciando no canto superior direito canalículos. Embora pouco visível, ocorre deposição de carbonato laminado abaixo da impressão foliar.

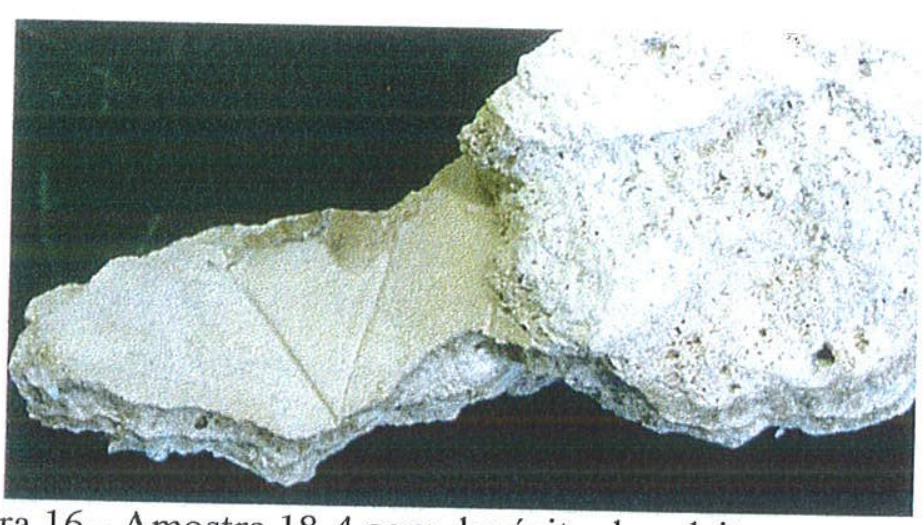

Figura 16 - Amostra 18-4 com depósito de calcita esparítica em faixas bem escuras e claras.

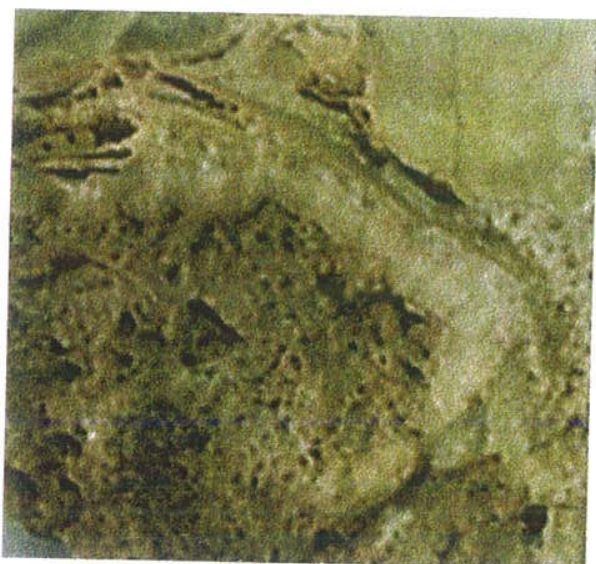

Figura 17- Amostra 23-9 apresentando lâminas de carbonato associado à folha $\mathrm{e}$ aos canalículos. 
Como exposto, o destino das folhas é afetado pela natureza do ecossistema aquático onde foram incorporadas. A preservação pode ser influenciada pela profundidade, turbulência e distância da margem. O estudo das condições de deposição, além da análise do padrão de biodegradaçăo e de fragmentação das folhas, pode fornecer informações sobre o ecossistema aquático pretérito (Spicer, 1981; Ferguson, 1985; Rich, 1989).

\section{3 - Análise tafonômica dos depósitos de Campo Formoso, BA}

Foi possivel identificar diatomáceas, clorófitas, cianoficeas, palinomorfos e ostracódes nos depósitos, não tendo sido realizados estudos taxonômicos.

A distribuição por classe de tamanhos das tafofloras nos três afloramentos de Campo Formoso indica o predomínio de folhas micrófilas II e III, assim como de folhas micrófitas I e mesófilas I e II, correspondente à distribuição segundo curva normal com tendência de classes de tamanhos maiores. $O$ transporte, aparentemente, não interfere na preservação das folhas, embora as classes mesófilas I e II tenham tido seus tamanhos estimados. Como exemplos de tafofloras brasileiras analisadas tafonomicamente, são citadas aqui as camadas Nova lorque, depósitos do Rio Parnaíba, MA, que ao contrário de Campo Formoso exibe sensível quebra na distribuição normal esperada (Cristalli, 1997).

As frequêencias de folhas com aparência tauterizada nos três afloramentos são pequenas, embora ocorram variações entre os diferentes pontos amostrados. Pode-se admitir neste caso, que o tempo de permanência em ambiente subaéreo tenha sido pequeno ou mesmo inexistente e a grande maioria das folhas teria alcançado diretamente um corpo aquoso. Em Campo Formoso, BA, a degradação microbiológica responsável pela aparência tauterizada é gradativamente menor quanto mais antiga for a idade do afloramento, o que seria devido ao aquecimento climático após o máximo glacial. Deste modo, o afloramento Salgadinho, representativo do último máximo glacial, exibe apenas $6 \%$ de folhas tauterizadas, enquanto que o afloramento Pacui, da fase interglacial atual, exibiu $12 \%$.

As observações de grande parte das folhas dos três afloramentos são incompletas, decorrente das condições de jazimento, muitas delas dobradas ou dispostas em planos diferentes. Apenas cerca de $10 \%$ das folhas podem ser consideradas incompletas devido ao transporte. A variação entre os afloramentos deve-se provavelmente a diferenças dos subambientes deposicionais. 
Os dados referentes ao estudo tafonomico dos macrofitofósseis encontram-se sintetizados na tabela 2:

\begin{tabular}{|c|c|c|c|c|c|c|c|c|c|}
\hline \multicolumn{2}{|c|}{$\begin{array}{l}\text { Pontos de } \\
\text { coleta }\end{array}$} & $\begin{array}{l}\text { foollias inteiras } \\
\text { Nüncro e \% }\end{array}$ & \multicolumn{2}{|c|}{$\begin{array}{l}\text { Folhas qucbradas } \\
\text { Número } 0 \%\end{array}$} & $\begin{array}{l}\text { Com degradayão } \\
\text { microbiologica }\end{array}$ & $\begin{array}{l}\text { Com degradaçás } \\
\text { invertebrados }\end{array}$ & \multicolumn{2}{|c|}{ Folhas anatisadas } & \multirow{2}{*}{$\begin{array}{l}\text { Total } \\
\text { follats } \\
\frac{29}{4}\end{array}$} \\
\hline \multirow{6}{*}{ 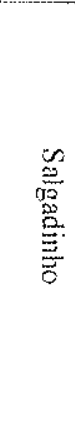 } & 1 & $1684 \%$ & 2 & $10,5 \%$ & $4 \quad 13,7-21 \%$ & $13,5.5 \%$ & 19 & $65 \%$ & \\
\hline & 4 & $2485 \%$ & 2 & $7,0 \%$ & $32,9-10,7 \%$ & $00 \%$ & 28 & $27 \%$ & 102 \\
\hline & 10 & $80 \%$ & 0 & $0 \%$ & $17,1 \%$ & $00 \%$ & 5 & $35,7 \%$ & 14 \\
\hline & 12 & $6 \quad 100 \%$ & 0 & $0 \%$ & $1 \quad 16,6 \%$ & $0 \quad 0 \%$ & 6 & $100 \%$ & 6 \\
\hline & 13 & $2100 \%$ & 0 & $0 \%$ & $00 \%$ & $0 \quad 0 \%$ & 2 & $100 \%$ & 2 \\
\hline & 14 & $70 \%$ & 2 & $20-22 \%$ & $22,6-20 \%$ & $12,6-20 \%$ & 10 & $13,3 \%$ & 75 \\
\hline \multicolumn{2}{|c|}{ Total } & $52 \quad 92,8 \%$ & 4 & $6,6-7,1 \%$ & $96,1-15 \%$ & $32 .-5 \%$ & $60-56$ & $40,8 \%$ & 147 \\
\hline \multirow{8}{*}{ 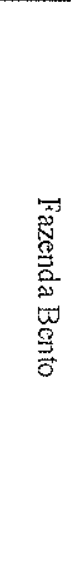 } & 15 & $675 \%$ & 4 & $25 \%$ & $423-50 \%$ & $16-12,5 \%$ & 8 & $47 \%$ & 17 \\
\hline & 16 & $6 \quad 66-85 \%$ & 1 & $11-14 \%$ & $00 \%$ & $16-11,1 \%$ & 9 & $53 \%$ & 17 \\
\hline & 17 & $2066-77 \%$ & 6 & $20-23 \%$ & $810-26,6 \%$ & $22-6,6 \%$ & 30 & $39 \%$ & 77 \\
\hline & 18 & $1575 \%$ & 4 & $20 \%$ & $35,5-15 \%$ & $23,7 \% 10 \%$ & 20 & $37 \%$ & 54 \\
\hline & 19 & $2281-88 \%$ & 3 & $11 \sim 12 \%$ & $77,2-26 \%$ & $00 \%$ & 27 & $28 \%$ & 97 \\
\hline & 20 & $1982,6 \%$ & 2 & $8,7 \sim 9,5 \%$ & $6 \quad 6,2-26 \%$ & $22,1-87 \%$ & 23 & $23,7 \%$ & 97 \\
\hline & 21 & $100 \%$ & 0 & $0 \%$ & $15,5-16,6 \%$ & $00 \%$ & 6 & $33 \%$ & 18 \\
\hline & 22 & $3188,6 \%$ & 7 & $5,7-18 \%$ & $109-28,6 \%$ & $33-8,6 \%$ & 35 & $33 \%$ & 106 \\
\hline \multicolumn{2}{|c|}{ Total } & $13287.93 \%$ & 23 & $14-14,8 \%$ & $41 \quad 8,5-24 \%$ & $112,7-7 \%$ & $168-155$ & $30 \%$ & 483 \\
\hline \multirow{2}{*}{ 苋 } & 23 & $25 \quad 81-89 \%$ & 3 & $9,6-10,7 \%$ & $9 \quad 9,5-29 \%$ & $3-9,7 \%$ & 31 & $32 \%$ & 95 \\
\hline & 26 & $2370-88 \%$ & 3 & $9-11,5 \%$ & $14 \quad 14-42,4 \%$ & $3 \quad 3-9,1 \%$ & 33 & $32 \%$ & 99 \\
\hline \multicolumn{2}{|c|}{ Total } & $48 \quad 75-89 \%$ & 6 & $9,4-11,1 \%$ & $2311,8-26 \%$ & $6 \quad 3-9,4 \%$ & $64-54$ & $30 \%$ & 194 \\
\hline
\end{tabular}

Tabela 2 - Análise quantitativa das feições tafonômicas foliares em cada ponto de coleta de amostras nos três afloramentos de tufos calcários estudados em Campo Formoso, BA. A análise apresenta dois valores porcentuais para cada característica devido a grande diferença entre o número de folhas visíveis na amostra e o número de folhas que efetivamente podem ser analisadas segundo critérios tafonômicos.

Poder-se-ia aventar a hipótese de deposição em corpo aquoso de baixa energia baseada na alta freqüência de folhas inteiras. Mas como a deposição de tufos calcários ocorre em ambiente de águas agitadas, a boa preservação poderia ser atribuida ao tempo curto, insuficiente para maior degradação, isto é, pouco transporte. 
Mais de $80 \%$ do total de espécimes não mostra qualquer sinal de degradação microbiológica ou por invertebrados. A degradação pode ser maior ou menor de acordo com o ponto amostrado independente do afloramento, conduzindo a dedução de pequeno de transporte. Pelo observado na região de Bonito, MS, é mais importante a diferenciação de preservaçōes de impressões de compressões.

Os atributos tafonômicos foram organizados em três tabelas: I com os dados referentes a "aragonita" (deposição de carbonato bem poroso lembrando o hábito fíbroso da aragonita), camadas alternadas de carbonato compacto e carbonato poroso, lâminas de carbonato e camada de carbonato compacto com calcita esparítica; II com os dados referentes a calcita esparitica, bolhas e cavidades; e III com os dados referentes a canalículos, canais de escoamento e estrutura tubular. Aqueles atributos que não se encontram presentes na coluna "estrutura relacionada", não são atribuidos a nenhuma das estruturas analisadas, apesar de terem sido levados em consideração no momento da análise. Estes dados serão úteis na identificação de sub-ambientes deposicionais, como mostrado mais adiante.

A diferenciação de canalículo, canal de escoamento e estrutura tubular é feita pelo diâmetro da estrutura: canalículos $(0,1$ a 0,3 centímetros), canais de escoamento $(0,5$ a 1,0 centímetros) e estruturas tubulares (maior que 1,0 centímetros).

De modo geral, são mais comuns canais de escoamento e canalículos, estando esses últimos sob folhas ou não. As folhas distribuem-se aleatoriamente, normalmente em vários planos distintos.

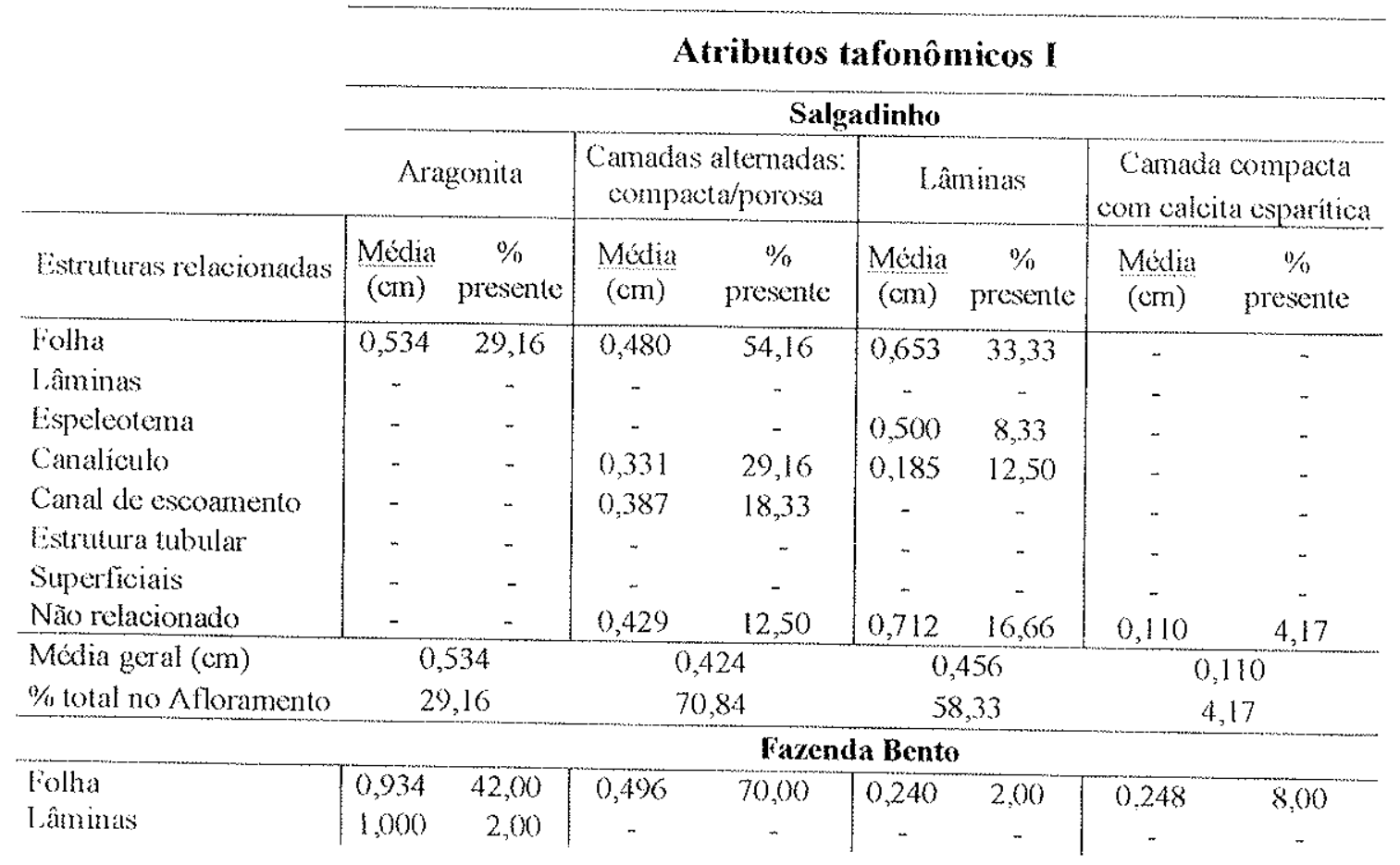

Tabela 03 - Atributos tafonômicos I dos Afloramentos Salgadinho, Fazenda Bento e Pacuí. 


\begin{tabular}{|c|c|c|c|c|c|c|c|c|}
\hline & \multicolumn{2}{|c|}{ Aragonita } & \multicolumn{2}{|c|}{$\begin{array}{l}\text { Camalas allomadas: } \\
\text { compacta/porosa }\end{array}$} & \multicolumn{2}{|c|}{ Lâminats } & \multicolumn{2}{|c|}{$\begin{array}{l}\text { Camada compacta } \\
\text { com calcita esparítica }\end{array}$} \\
\hline I Etromas relacionadas & $\frac{\text { Media }}{(\mathrm{cm})}$ & $\begin{array}{c}\% \\
\operatorname{prcsen} t c\end{array}$ & $\frac{\text { Média }}{(\mathrm{cm})}$ & $\begin{array}{c}\% / \% \\
\text { presente }\end{array}$ & $\frac{\text { Média }}{(\mathrm{cm})}$ & prosente & $\frac{\text { Media }}{(\mathrm{cm})}$ & $\begin{array}{c}\% \\
\text { presente }\end{array}$ \\
\hline Eapelootema & - & - & - & - & - & - & - & - \\
\hline Canaliculo & 0,408 & 2,00 & 0,221 & 24,00 & - &. & 0.220 & 4,00 \\
\hline Camal de cicoamento & - & - & - & - & $\sim$ & - & - & - \\
\hline Estrutura tubuar & . & - & - & - & 0,290 & 2,00 & 0,210 & 2,00 \\
\hline Superficias & - & - & - & - & - & - & - & - \\
\hline Năo relacionado & 1,588 & 18,00 & 0,278 & 24,00 & 0,200 & 2,00 & 0,250 & 2,00 \\
\hline Media geral $(\mathrm{cm})$ & \multicolumn{2}{|c|}{1,105} & \multicolumn{2}{|c|}{0,550} & \multicolumn{2}{|c|}{0,210} & \multicolumn{2}{|c|}{0,233} \\
\hline$\%$ total no slloramento & \multicolumn{2}{|c|}{50,00} & & & \multicolumn{2}{|c|}{6,00} & \multicolumn{2}{|c|}{16,00} \\
\hline & \multicolumn{8}{|c|}{ Pacuí } \\
\hline Folha & 1,480 & 30.00 & 0,393 & 90,00 & $一$ & - & 1,055 & 6,66 \\
\hline Lâminas & - & -. & - & - & - & - & - & - \\
\hline Lispeleotemal & - & - & - & - & - & - & - & - \\
\hline Canaliculo & 0,140 & 3,33 & 0,217 & 66,66 & - & - & 0,263 & 3,33 \\
\hline Canal de escoamento & - & - & 0,230 & 6,66 & - & - & - & - \\
\hline Gstrutura tubular & - & - & 0,255 & 6,66 & - & - & - & - \\
\hline Superticiais & 0,112 & 3,33 & - & - & - & - & - & - \\
\hline Năo relacionado & 1,500 & 20,00 & 0,636 & 20,00 & - & - & - & - \\
\hline \multirow{2}{*}{$\begin{array}{l}\text { Media geral }(\mathrm{cm}) \\
\% \text { total no Aflomento }\end{array}$} & \multicolumn{2}{|c|}{1,400} & \multicolumn{2}{|c|}{0,346} & \multicolumn{2}{|c|}{0} & \multicolumn{2}{|c|}{0,791} \\
\hline & \multicolumn{2}{|c|}{43,33} & \multicolumn{2}{|c|}{96,67} & \multicolumn{2}{|c|}{0} & \multicolumn{2}{|c|}{6,66} \\
\hline
\end{tabular}

Tabela 03 (cont.) - Atributos tafonômicos I dos Afloramentos Salgadinho, Fazenda Bento e Pacuí.

Atributos tafonômicos II

\begin{tabular}{|c|c|c|c|c|c|}
\hline \multirow[b]{3}{*}{ Estruturas relacionadas } & \multicolumn{5}{|c|}{ Salgadinho } \\
\hline & \multirow{2}{*}{$\begin{array}{c}\text { Calcita } \\
\text { csparítica } \\
\% \\
\text { presente }\end{array}$} & \multicolumn{2}{|c|}{ Bolhas } & \multicolumn{2}{|c|}{ Cavidades } \\
\hline & & $\begin{array}{l}\text { Média } \\
\text { por amostra }\end{array}$ & $\begin{array}{c}\% \\
\text { presente }\end{array}$ & $\frac{\text { Media }}{\text { por amostra }}$ & $\begin{array}{c}\% / 0 \\
\text { presente }\end{array}$ \\
\hline Folha & 16,66 & 10,36 & 45,83 & 1,57 & 29.16 \\
\hline - Compressão & - & - & - & 1,00 & 16,66 \\
\hline - Impressão & - & - & - & 1,80 & 8,33 \\
\hline Camadas alternadas: compacta/porosa & 16,66 & - & - & - & $\sim$ \\
\hline Camada compacta e calcita esparitica & 4,16 & - & - & - & - \\
\hline Lâninas & 4,16 & - & - & - & - \\
\hline Aragonita & - & + & - & - & - \\
\hline Cavidades & - & 3,20 & 10,00 & $\therefore$ & - \\
\hline Fspeleotema & 8,33 & - & - & - & - \\
\hline Canaliculo & 12,50 & - & - & - & - \\
\hline Canal de escomento & 4,16 & - & - & - & - \\
\hline Dispersos & 4,16 & 3,50 & 8,33 & - & - \\
\hline Superficiais & - & 13,50 & 12,50 & - & - \\
\hline Não relacionado & - & - & - & 4,58 & 45,83 \\
\hline \multirow{2}{*}{$\begin{array}{l}\text { Média geral } \\
\% \text { total no Aforamento }\end{array}$} & - & \multicolumn{2}{|c|}{8,50} & \multicolumn{2}{|c|}{3,88} \\
\hline & 58,33 & \multicolumn{2}{|c|}{70,84} & \multicolumn{2}{|c|}{70,84} \\
\hline
\end{tabular}

Tabela 04 - Atributos tafonômicos II dos Afloramentos Salgadinho, Fazenda Bento e Pacuí. 


\begin{tabular}{|c|c|c|c|c|c|}
\hline & \multirow{2}{*}{$\begin{array}{l}\text { Calcita } \\
\text { esparitica } \\
\frac{1 / 0}{\text { presente }}\end{array}$} & \multicolumn{2}{|c|}{ Bothas } & \multicolumn{2}{|c|}{ Cavidads } \\
\hline Estruturas relacionadas & & $\begin{array}{c}\text { Mcdiat } \\
\text { por anostra }\end{array}$ & $\begin{array}{c}\% \\
\text { presente }\end{array}$ & $\frac{\text { Media }}{\text { por amostra }}$ & $\begin{array}{c}0 / 4 \\
\text { presente }\end{array}$ \\
\hline & \multicolumn{5}{|c|}{ Fazenda Bento } \\
\hline Follua & 50,00 & 10,00 & 54,00 & 1,46 & 30.00 \\
\hline - Compressão & - & - & - & 1,20 & 20,00 \\
\hline - Impressão & - & - & - & 1,80 & 12,00 \\
\hline Camatas altenadas: compacta/porosá & 42,00 & 5,00 & 2,00 & - & - \\
\hline Camadas compacta e calcila esparitica & - & - & - & - & - \\
\hline Lâminas & 2,00 & - & - & - & - \\
\hline Aagonita & 10,00 & 7,50 & 4,00 & - & - \\
\hline Cavidades & - & 3,75 & 8,00 & - & - \\
\hline Espelcotema & - & - & - & - & - \\
\hline Canaliculo & 6,00 & - & - & - & - \\
\hline Canal de escoamento & 2,00 & 4,00 & 4,00 & - & - \\
\hline Dispersos & 12,00 & 9,00 & 6,00 & - & - \\
\hline Superficiais & - & 10,00 & 6,00 & - & - \\
\hline Não relacionado & - & $1 !, 00$ & 2,00 & 2,29 & 36,00 \\
\hline Média geral & - & \multicolumn{2}{|c|}{9,89} & \multicolumn{2}{|c|}{2,22} \\
\hline \multirow[t]{2}{*}{$\%$ total no Aloramento } & 72,00 & \multicolumn{2}{|c|}{68,00} & \multicolumn{2}{|c|}{52,00} \\
\hline & \multicolumn{5}{|c|}{ Pacuí } \\
\hline Fotha & 36,66 & 7,00 & 50,00 & 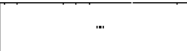 & - \\
\hline - Compressão & - & - & - & - & . \\
\hline - Impressĩo & - & - & - & - &. \\
\hline Camadas altemadas: compacta/porosa & 86,66 & - & - & - & - \\
\hline Camadas compacta o calcita csparítica & - & - & - & - & - \\
\hline Lâminas & - & - & - & - & . \\
\hline Aragonita & 26,66 &. & - & - & - \\
\hline Cavidades & - & - & $\sim$ & -. & - \\
\hline Canalículo & - & - & - & - & - \\
\hline Dispersos & 10,00 & - & - & - & $\cdot$ \\
\hline Superticiais & - & - & - & 1,00 & 6,67 \\
\hline Não relacionado & 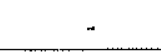 & 11,50 & 6,66 & - & - \\
\hline Média geral & - & \multicolumn{2}{|c|}{7,53} & \multicolumn{2}{|c|}{1,00} \\
\hline$\%$ total no Afloramento & 90,00 & \multicolumn{2}{|c|}{56,67} & \multicolumn{2}{|c|}{6,67} \\
\hline
\end{tabular}

Tabela 04 (cont.) - Atributos tafonômicos II dos Afloramentos Salgadinho, Fazenda Bento e Pacuí. 


\section{Atributos tafonômicos III}

listuturas analisadas

\begin{tabular}{|c|c|c|c|c|c|c|c|c|c|}
\hline \multirow{4}{*}{ Estruturas relacionadas } & \multicolumn{9}{|c|}{ Salesadinbo } \\
\hline & \multicolumn{3}{|c|}{ Canalicalos } & \multicolumn{3}{|c|}{ Canais de escomento } & \multirow{2}{*}{\multicolumn{3}{|c|}{$\begin{array}{l}\text { Bitrutura abular } \\
\text { Media }\end{array}$}} \\
\hline & \multicolumn{2}{|c|}{ Mćdia } & \multirow[t]{2}{*}{ 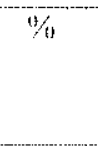 } & \multicolumn{2}{|c|}{ Media } & \multirow[t]{2}{*}{$\%$} & & & \\
\hline & $\begin{array}{c}\text { por } \\
\text { amostá }\end{array}$ & $\theta(\mathrm{cm})$ & & $\begin{array}{c}\text { por } \\
\text { amostra }\end{array}$ & $O(\mathrm{~cm})$ & & $\begin{array}{c}\text { por } \\
\text { amostra }\end{array}$ & $O(\mathrm{~cm})$ & $\%$ \\
\hline Folha & 13,07 & 0,163 & 58,33 & 1,00 & 0,500 & 4,16 & - & - & - \\
\hline $\begin{array}{l}\text { Camadas altemadas: } \\
\text { compacta/porosa }\end{array}$ & - & - & - & - & - & - & - & - & - \\
\hline Aragonila & 1,00 & 0.240 & 4,16 & - & - & - & - & - & - \\
\hline Cavidades & - & - & - & - & - & .. & . & - & - \\
\hline Estrutua tubular & - & - & - & - & - & .. & - & .. & - \\
\hline Superticiass & - & - & - & 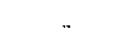 & - & - & 1,00 & 3,54 & 4,16 \\
\hline Não relacionado & 11,00 & 0,174 & 70,83 & 1,41 & 0,715 & 50,00 & 1,25 & 2,36 & 16,66 \\
\hline \multicolumn{4}{|l|}{ Média geral por amostra } & \multicolumn{3}{|c|}{1,38} & \multicolumn{3}{|c|}{1,20} \\
\hline Mćdia geral $O(\mathrm{~cm})$ & \multicolumn{3}{|c|}{0,171} & \multicolumn{3}{|c|}{0,698} & \multicolumn{3}{|c|}{2,16} \\
\hline$\%$ tolal no Aloramento & \multicolumn{3}{|c|}{95,83} & \multicolumn{3}{|c|}{54,17} & \multicolumn{3}{|c|}{20,83} \\
\hline
\end{tabular}

Fazenda Bento

\begin{tabular}{|c|c|c|c|c|c|c|c|c|c|}
\hline Folha & 10,74 & 0,197 & 52,00 & 2,33 & 0,688 & 12,00 & 1,33 & 1,545 & 6,00 \\
\hline $\begin{array}{l}\text { Camadas alternadas: } \\
\text { compacta/porosa }\end{array}$ & 8,50 & 0,150 & 1,00 & - & - & - & .. & - & - \\
\hline Aragonita & 10,00 & 0,100 & 2,00 & 1,00 & 0,540 & 2,00 & - & - & - \\
\hline Cavidades & 15,00 & 0,100 & 2,00 & - & - & - & - & - & .. \\
\hline Estrutura tubular & 1,00 & 0,440 & 2,00 & $\sim$ & - & - & - & - & - \\
\hline Superficiais & 2,50 & 0,282 & 4,00 & 1,00 & 0,700 & 2,00 & 1,55 & 1,350 & 4,00 \\
\hline Não relacionado & 7,40 & 0,191 & 54,00 & 1,00 & 0,545 & 4,00 & 1,66 & 1,680 & 6,00 \\
\hline Média geral por amostra & \multicolumn{3}{|c|}{12,40} & \multicolumn{3}{|c|}{2,00} & \multicolumn{3}{|c|}{1,42} \\
\hline Mćdia geral $O(\mathrm{~cm})$ & \multicolumn{3}{|c|}{0,196} & \multicolumn{3}{|c|}{0,640} & \multicolumn{3}{|c|}{1,580} \\
\hline$\%$ total no Afloramento & \multicolumn{3}{|c|}{84,00} & \multicolumn{3}{|c|}{18,00} & \multicolumn{3}{|c|}{14,00} \\
\hline
\end{tabular}

Pacuí

\begin{tabular}{|c|c|c|c|c|c|c|c|c|c|}
\hline Folha & 18,31 & 0,190 & 80,00 & 1,66 & 0,506 & 10,00 & 1,00 & 1,320 & 6,66 \\
\hline $\begin{array}{l}\text { Camadas altemadas: } \\
\text { compacta/porosa }\end{array}$ & 5,00 & 0,480 & 3,33 & - & - & - & - & - & - \\
\hline Aragonita & 12,75 & 0,128 & 13,33 & $\sim$ & - & - & - & - & 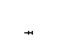 \\
\hline Cavidades & - & - & - & - & - & - & - & - & - \\
\hline Estrutura tubulat & - & - & - & - & - & - & - & - & - \\
\hline Superficiais & 51,00 & 0,136 & 10,00 & - & - & - & - & - & - \\
\hline Não relacionado & 13,26 & 0,140 & 63,33 & 1,50 & 0,630 & 6,66 & 2,00 & 1,700 & 6,66 \\
\hline $\begin{array}{l}\text { Média geral por amostra } \\
\text { Média geral } O(\mathrm{~cm}) \\
\% \text { total no Afloramento }\end{array}$ & \multicolumn{3}{|c|}{$\begin{array}{l}28,86 \\
0,160 \\
0000\end{array}$} & \multicolumn{3}{|c|}{$\begin{array}{l}2,00 \\
0,695 \\
13,33\end{array}$} & \multicolumn{3}{|c|}{$\begin{array}{l}1,50 \\
1,510 \\
6,67\end{array}$} \\
\hline
\end{tabular}

Tabela 05 - Atributos tafonômicos III dos Afloramentos Salgadinho, Fazenda Bento e Pacuí 
Abaixo da superficie da folha ocorrem lamelas de calcita. Na maioria das amostras observam-se apenas faixas correspondentes ao crescimento da calcita, tendo a folha como núcleo de precipitação.

A presença de folhas e de suas impressões, acompanhadas de cavidades, é sugestiva de certa decomposição das folhas e alteração do $\mathrm{pH}$, responsável pela dissolução diagenética do carbonato acima das folhas. Como nem todas as impressões estão associadas a cavidades, seria mais provável supor que estas folhas tenham sido degradadas microbiologicamente, anteriormente à deposição. Desse modo, apenas as impressões não associadas a cavidades poderiam fornecer dados tafonômicos. As pesquisas realizadas em Bonito, MS comprovam que algumas folhas podem chegar ao depósito já degradadas microbiologicamente e, dessa forma, só podem ser preservadas como impressões, corroborando o exposto.

Diferentemente dessas cavidades, grandes espaços vazios podem estar presentes sem qualquer relaçăo com as folhas. A deposição de carbonato ocorre intimamente associada às folhas, eventualmente com pequena quantidade de sedimento agregado ao depósito.

As características sedimentológicas como friabilidade, porosidade e aspecto maciço ou estratificado; a presença de canalículos e canais de escoamento; e a presença de cavidades, são caracteristicas comuns a todos os pontos amostrados em Campo Formoso, não havendo diferenças estatisticas que pudessem ser utilizadas na distinção de sub-ambientes deposicionais. Outras características, no entanto, quando analisadas em conjunto, permitem o reconhecimento dos subambientes deposicionais.

Em comparação com os depósitos de Bonito, MS, pode-se reconhecer que em locais com alta turbulência, o carbonato precipita-se lentamente apresentando as maiores espessuras de calcário laminado disposto sobre as folhas, com 0,2 a 0,6 centímetros de espessura acompanhadas de 8 a 20 bolhas por amostra. A deposição similar a fibras de aragonita ocorre apenas sob núcleos de precipitação com espessura máxima de 0,76 centímetros. Apenas de 10 a $20 \%$ das folhas exibem degradação microbiológica. Tal ocorrência encontra-se principalmente no afloramento Salgadinho representado pelos pontos 1, 4 e 14 e precisa de outras características associadas para permitir reconhecimento de sub-ambiente deposicional. O posicionamento dos pontos de coleta estão apresentados na figura 6 (página 26). 
No afloramento Fazenda Bento (ponto 15) e no afloramento Pacui (ponto 26), a calcita é mais porosa, a rocha é proporcionalmente mais clara e as folhas possuem menos contrastes. Diferentemente das amostras descritas acima, além das dicotiledôneas, monocotiledôneas também são preservadas, a maioria das folhas como impressões. As paredes dos canais de escoamento e canalículos são finas ou grossas, mas sempre com uma luz relativamente ampla. Como parâmetros que podem ser facilmente mensurados, ocorrem folhas com 42 a $50 \%$ de degradação microbiológica e ausência de calcário laminado. Ocorrem fibras semelhantes a aragonita com espessura de 1,5 a $1,7 \mathrm{~cm}$ e cerca de 8 bolhas por amostra. As amostras do ponto 26 do afloramento Pacui podem ser subdividividas em dois grupos, um deles com características indicativas de maior turbulência e outro grupo indicativas de menor energia, talvez relacionadas a períodos sazonalmente com maior volume de água no sistema.

A coloração clara normalmente não é um parâmetro adequado, ao contrário do aspecto poroso esponjoso, como se o carbonato tivesse sido depositado rapidamente. Normalmente as amostras apresentam canais e canalículos geralmente sob as folhas, que são esparsas e preservadas como impressões. As possíveis compressões são pouco visiveis motivadas por recobrimento espesso de calcita. Sob muitas folhas ocorre a deposição perpendicular de carbonato constituindo faixas, possivelmente de aragonita. A deposição preferencial de aragonita pode estar associada a maior evaporação no local, proporcionando precipitação mais rápida.

Alguns pontos dos afloramentos da Fazenda Bento e de Pacui, exibem amostras com feições intermediárias, embora apresentem pequena espessura ou nenhuma presença de calcário laminado. $\mathrm{O}$ porcentual de degradação microbiológica é menor, variando de 26 a $29 \%$, sugerindo menor transporte das folhas e a espessura do depósito fibroso semelhante à aragonita é menor, variando de 0,9 a $1,2 \mathrm{~cm}$. O ponto 17, da Fazenda Bento e o ponto 23 de Pacui, exibem variações destas características nas amostras, podendo sugerir depósitos em região de condições variáveis sazonalmente ou temporalmente. Os pontos 20 e 22 da Fazenda Bento são os únicos deste afloramento que exibem calcário laminado, sendo que no ponto 20 também ocorrem pequenos depósitos de calcita esparítica, mas nenhum subambiente especifico pode ser definido. Já no ponto 19 , ocorre freqüente preservação de bainhas de monocotiledôneas, isto é, a base de suas folhas, o que poderia sugerir região relativamente plana, com presença de vegetação acima de tufos nas laterais do leito ou mesmo dentro do leito do rio, como observado em Bonito, MS. As bainhas teriam sido incorporadas ao registro pela deposição de carbonato em suas porções submersas, enquanto que o restante da folha morreria e seria decomposta sem participar do registro. 
Em suma, a classificaçăo de Jassen et al. (1999). observa-se que os mecanismos de deposição dos tufos calcários no Brasil não correspondem aos descritos para a Europa, embora sejam mais semelhantes aos tufos porosos porém duros.

As observações feitas na região de Bonito, MS auxiliaram a compreensão dos depósitos fósseis de Campo Formoso principalmente para o reconhecimento dos tufos depositados em fluxo turbulento. A presença de monocotiledôneas em diferentes condições também permitiu melhor entendimento da preservação tão incomum desses vegetais. A partir dessas análises, outros sub-ambientes puderam ser definidos por comparação, através do conjunto de suas características.

Para o reconhecimento de fluxo mais turbulento, a principal caracteristica é a presença de calcário laminado bem desenvolvido abaixo das fothas. Características auxiliares corresponde a pequena espessura ou mesmo ausência de calcário mais fibroso semelhante a aragonita, abaixo das folhas e maior presença de bolhas preservadas. O porcentual de degradação microbiológica pode ser devido ao clima, já que o porcentual mais baixo foi registrado no afloramento Salgadinho, depositado no máximo periodo glacial, mesmo que sua deposição tenha continuado ativa até o pós-glacial. Tal condição também pode ser utilizada para explicar a maior turbulência, provavelmente devido ao maior volume d'água presente neste periodo.

Nos demais afloramentos, percebe-se aumento no porcentual de degradação microbiológica, compativel com o aumento da temperatura. Diferenças neste porcentual de degradação nos afloramentos de idades mais recentes foram utilizadas para definir diferentes sub-ambientes de deposição.

Outra característica distintiva corresponde ao tipo de preservação de monocotiledôneas, visto que esses vegetais não apresentam abscisão sendo geralmente preservadas in situ ou em condições muito especiais. 
6 - Resultados taxonômicos e suas interpretações

Durante os trabalhos realizados no Herbário ALCB da Universidade Federal da Bahia, foram descritas mais de 2.000 espécies pertencentes a 871 gêneros de 153 familias. Não foram analisadas as familias de monocotiledôneas, não só pela dificuldade ou mesmo impossibilidade de identificação taxonômica de suas folhas, normalmente de nervuras paralelas com poucas variações macroscópicas. Além disso, não permitem utilização em análises paleoclimáticas baseadas em fisionomia foliar.

A abundância de monocotiledôneas, entretanto, é de grande importância nas interpretações paleoclimáticas. Nas assembléias de Campo Formoso aparecem monocotiledôneas, principalmente no afloramento Salgadinho, com quatro morfologias foliares diferentes. Em alguns pontos, tanto de Salgadinho quanto dos outros afloramentos, é possivel reconhecer a possivel presença de bainhas das folhas de monocotiledoneas preservadas, indicando a possibilidade de preservação devido ao tipo de subambiente deposicional. Normalmente as folhas de monocotiledoneas tem pequeno potencial de preservação por não apresentarem abscisão, mas no caso de Campo Formoso parece que as bainhas foram recobertas por carbonato de cálcio, ainda com a planta em vida nas proximidades de um corpo aquoso.

Também não foram analisadas as leguminosas, que constitui um grupo numeroso e de grande diversidade tendo em vista a grande similaridade no padrão de nervação de seus taxa. O tempo para pesquisas, no entanto, foi o principal fator limitante. O trabalho de herbário foi realizado em apenas 1 mês, quando foram produzidas mais de 20.000 fotos. Por motivos semelhantes, as famílias Asteraceae, Melastomataceae e Cactaceae também não foram analisadas. As famílias Rubiaceae e Myrtaceae foram documentadas, mas não puderam ser descritas durante os trabalhos do herbário. As análises fisionômicas não serão prejudicadas, mas as comparações pelo padrão das nervuras não serão tão precisas em relação a essas duas famílias. O herbário SPF contribuiu nas comparações, com espécimes do Complexo Vegetacional Atlântico e do Cerrado encontradas em São Paulo, Minas Gerais e também outros locais, inclusive Bahia.

$\mathrm{Na}$ tabela 6 (páginas 94-96) registram-se as localidades e o tipo de vegetação nas quais as espécies que permitiram a identificação taxonômica dos espécimes fósseis foram documentadas. Tendo-se como base o herbário ALCB, a grande maioria das localidades registradas situa-se no Estado da Bahia. Sempre que o material estudado não se localizar neste Estado, o estado da federação será devidamente indicado. 


\section{1 - Identificação taxonômica}

Ocorrência das diferentes características

a) Limbo foliar năo inteiro

Nem sempre é făcil reconhecer a ocorrència de limbo foliar lobado, fendido ou mesmo dissecado, porque tal característica pode ser confundida com o processo de fossilização, mas corresponde também a importante fèição diagnóstica. Mesmo só possuindo dois espécimes pentalobados provenientes do afloramento Salgado, único afloramento sem idade determinada, esta característica define o morfotipo 1 .

O morfotipo I foi reconhecido como Cecropia saxatilis (Cecropiaceae) pertencente até há pouco tempo à família Moraceae. A espécie exibe a mesma característica de lobação do morfotipo, com o lobo central bem mais desenvolvido que os outros dois pares. A nervação é a que mais chama a atenção, devido a forte interconexão existente entre a nervação de cada lobo. Outras características comuns estão presentes como a nervação eucampdódroma e o mesmo tipo de nervação percorrente. Baixo grau de incerteza na identificação.

A família Moraceae latu sensu possui 61 gêneros e mais de 1.000 espécies tropicais sendo plantas arbóreas ou arbustivas segundo Joly (1998) e possui cerca de 63 gêneros e 1.500 espécies tropicais e algumas temperadas, destes 28 gêneros e 340 espécies ocorrem no Brasil, sendo árvores, arbustos, ervas ou trepadeiras segundo Barroso et al. (2002). A espécie Cecropia saxatilis foi documentada em Salvador, Paraguaçu, Itaête, São Sebastião do Passé, Lamarão do Passé e Cairú em vegetações de floresta ombrófila densa, floresta estacional e restinga.

b) Margem não lisa.

A margem não lisa é considerada um caráter de climas frios e, segundo as análises fisionômicas, o porcentual de folhas com dentes por si só poderia indicar a temperatura a qual a vegetação está ou estava submetida. Deve-se levar em conta, contudo, que esse critério é válido especificamente para o Hemisfério Norte, onde o clima é frio e seco. Espécies de algumas familias tropicais sequer podem desenvolver dentes.

A vegetação da Caatinga é particularmente diferente. Das 153 famílias estudadas, 47 exibem pelo menos uma espécie sem margem lisa, conforme indica a tabela 9A (página 101-103). 
A proporção de espécies por gènero que exiba uma determinada caracteristica pode ser importante na relevância climática desta característica. Quanto mais espécies um gênero apresentar com esta característica, maior é a influência genética no caráter e menor a influência climática. Corresponderia a uma condição do próprio táxon. Nesses casos, a influência climática pode alterar o desenvolvimento da característica. No desenvolvimento da margem, por exemplo, gêneros que possuem espécies com dentes, podem ser mal desenvolvidos em clima úmido, constituindo apenas crenulações na margem foliar.

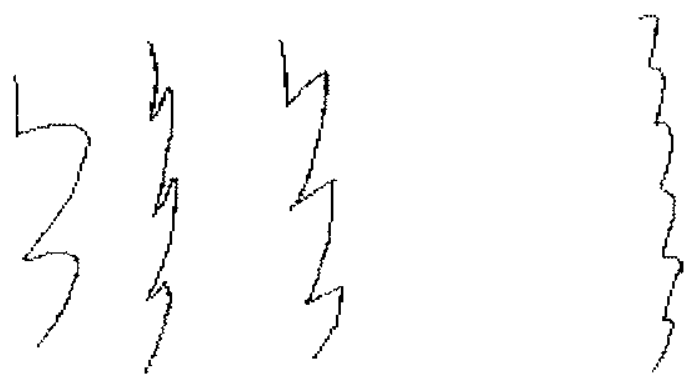

Figura 18 - Margem foliar com dentes bem desenvolvidos e margem crenulada.

Na assembléia de Campo Formoso, apenas dois espécimes exibiram dentes. São representados pelo morfotipo 2. Os espécimes apresentam tipos de dentes diferentes entre si, de forma que representam dois subgrupos. Ambos possuem nervação percorrente e se encontram fragmentados, dificultando as interpretações. Entretanto, o tipo de dente do morfotipo 2A, representado pelo espécime 14-1 a mostrou-se similar ao gênero Abutilon (Malvaceae), permitindo o reconhecimento, com grau moderado de incerteza apenas pela falta de outros caracteres, porque os dentes são considerados bons critérios sistemáticos.

c) Assimetria foliar.

Apenas 28 famílias mostraram assimetria foliar. Esse número pode parecer pequeno, mas o limbo assimétrico ocorre mais comumente em folhas compostas.

Esta característica está presente no morfotipo 3, subdividido em morfotipo $3 \mathrm{~A}$ e morfotipo $3 \mathrm{~B}$. $\mathrm{O}$ morfotipo $3 \mathrm{~B}$ é reconhecido como Leguminosae. Dentre as Leguminosae, foram encontradas três espécies que não são possíveis de serem identificadas conforme anteriormente comentado, embora um espécime seja parecido com o gênero Bauhnia. O espécime em questão pode ser observado na figura 31 (página 111 ). 
As Leguminosae, com ampla distribuiçăo geográfica, possuem cerca de 650 gêneros e 18.000 espécies, em très subfamílias bem distintas. Caesalpinoideae e Mimosoideae são principalmente tropicais, enquanto Faboideae é mais freqüente em regiões temperadas (Barroso, 1991a). São plantas de hábito muito variado, desde grandes árvores a arbustos, subarbustos, ervas anuais e perenes e também trepadeiras (Barroso, 1991 a; Joly, 1998). No cerrado são freqüentes as espécies de Eriosema, Galectice e Periandra (Barroso, 1991 a).

$\mathrm{O}$ morfotipo $3 \mathrm{~A}$ reúne as folhas assimétricas sem relação com as leguminosas. Dois destes espécimes puderam ser identificados: o espécime 23-9 como Tetrastylidium brasiliensis (Olacaceae) e o espécime 4-5a como Piper tectoniifolia (Piperaceae).

O espécime 23-9 apresenta forma elíptica encurvada, característica bem observada em T'etrastylidium brasiliensis. Sua nervação secundária emerge em ângulo agudo e torna-se ligeiramente encurvadas. Nervação terciária visivel, sem que se possa observar bem o seu padrão. Estas mesmas características estão presentes na espécie a qual foi comparado. Grau baixo a moderado de incerteza na identificação.

A família Olacaceae possui 27 gêneros e 230 espécies pantropicais (Barroso, 1991b). São plantas lenhosas, árvores ou arbustos com folhas inteiras. No Brasil ocorrem apenas 10 gêneros (Joly, 1998). A espécie Tetrastylidium brasiliensis não foi registrada em outras localidades além daquela do espécime que permitiu sua identificação.

Já o espécime 4-5a encontra-se fragmentado e poucos caracteres podem ser observados, com exceção de sua região basal. Ele chegou a ser comparado com espécies de três famílias, incluindo Malpighiaceae e Polygonaceae. A inclusão em Piperaceae ocorre devido ao curso e ao calibre das nervuras secundárias, por isso sua identificação apresenta grau moderado de incerteza. É importante ressaltar que a identificação de espécies vegetais através de suas folhas não corresponde a método seguro de identificação e a incerteza acompanha a identificação com maior ou menor grau. Sempre que o grau de incerteza não for baixo, o mesmo será informado porque pode não ser o táxon mencionado. Este cuidado é extremamente importante no momento de interpretar a vegetação como um todo.

A familia Piperaceae apresenta de 10 a 12 gêneros e 1.400 espécies distribuídas em todas as regiões tropicais. No Brasil são apenas 5 gêneros e 460 espécies (Barroso et al., 2002). Predominam os representantes herbáceos, mas existem trepadeiras, arbustos e até árvores, que possuem folhas inteiras. Seus gêneros mais diversificados são Piper, gênero do jaborandi e da pimenta-do-reino e Peperomia, usado como plantas ornamentais (Joly, 1998). 
d) Textura coriacea

O termo coriácea em botânica refere-me às folhas com textura resistente, em oposição a folhas denominadas membranosas. As folhas são coriáceas normalmente como proteção à perda de água, desenvolvendo uma cutícula mais espessa, embora esta caracteristica também possa ser conseguida pela maior quantidade de tecidos de sustentação como colênquima e principalmente esclerênquima. Em geral, o primeiro caso pode ser reconhecido no registro fossilifero, porque as folhas ficam com aparência diferenciada. No segundo caso, a folha precisaria ser manuseada com as mãos para se perceber esta resistência. Desse modo, apenas as folhas que apresentavam aparência coriácea foram consideradas neste estudo.

A aparência coriácea define o morfotipo 4. Como não é muito fácil observar outras características numa folha coriácea, esse morfotipo foi subdividido em 4 grupos baseados na forma foliar e na visibilidade das nervuras. Alguns espécimes não apresentam essas especificaçōes e estão incluídas no morfotipo 4 como o espécime 20-1j que, no entanto, pode ser atribuída a Maytenus cantingarum (Celastraceae) baseando-se em características tão comuns quanto tamanho, espessura da nervura primária, visibilidade das demais nervuras e o tipo de resistência, característica decorrente da própria estrutura coriácea, que fornece a folha dobradura peculiar, bem delimitada.

A família Celastraceae possui 60 gêneros de ampla distribuição tropical e subtropical, de hábito arbustivo ou arbóreo, com cerca de 850 espécies (Joly, 1998; Barroso, 1991a). O gênero Maylenus cantingarum é registrado na região da Chapada Diamantina nos municípios de Lençóis e Mucugê em mata ciliar e campo rupestre assim como na Mata Atlântica em Entre Rios, mas possivelmente possui distribuição mais ampla.

Análises mais detalhadas mostraram que o morfotipo 4A não corresponde a uma única morfoespécie. $O$ espécime 22-2m não chega a apresentar as nervuras em relevo, possui maior tamanho e no espécime 19-4r é possível observar nervuras terciárias. Ambos permanecem sem identificação. Entretanto, o espécime 23-4a pode ser comparado a Banisteriopsis stellaris (Malpighiaceae). A comparação foi possível devido à disposição das nervuras secundárias, assim como sua espessura. $\mathrm{O}$ curso das nervuras secundárias imprime-se no limbo, fazendo-o aparentar estar enrugado. Grau moderado a baixo de incerteza na identificação. A espécie Banisteriopsis stellaris está presente em Jacobina, Tucano, Morporá e Ribeira do Pombal em vegetação de caatinga e campo rupestre. 
A familia Malpighiaceae possui 63 gêneros e mais de 800 espécies pantropicais, sendo que no Brasil encontra-se distribuida em 32 gêneros e 300 espécies (Barroso, 1991 a). Săo plantas herbáceas, arbustivas, arbóreas ou mais freqüentemente trepadeiras com folhas inteiras (Joly, 1998). As folhas podem alcançar maiores dimensǒes em Byrsonima. A consistência das folhas é corrácea ou ainda membranosa, são freqüentemente pequenas, de forma lanceolar ou linear (Barroso, 1991 a).

$O$ morfotipo $4 B$ corresponde a um único espécime. Apresenta classe de tamanho maior e seu caráter coriáceo é mais forte, com menor visibilidade de suas nervuras. Devido ao tamanho, forma e caráter coriáceo foi comparado a três espécies: Actinostemum sp. (Euphorbiaceae) a Ternstroemia alnifolia (Theaceae) e a Connarus suberosus (Connaraceae). Foi identificado como Connarus suberosus devido a sua forma mais elíptica e espessura da nervura primária, mais constante ao longo do seu curso, ao contrário das outras duas espécies. Devido à presença de poucos caracteres diagnósticos há pequeno a moderado grau de incerteza nesta identificação, reduzido apenas por ter sido o espécime comparado a todo a coleção do herbário ALCB. Está se utilizando, então, o princípio de exclusão.

A família Connaraceae possui 8 gêneros de ampla distribuição tropical, segundo Joly (1998), mas possui 24 gêneros e entre 300 e 400 espécies, quatro deles ocorrendo no Brasil, segundo Barroso (1991a). São plantas lenhosas, arbóreas, arbustivas ou lianas de grande porte (Barroso, 1991a; Joly, 1998). No Brasil são freqüentes espécies de Connarus nos campos cerrados.

O morfotipo $4 \mathrm{C}$, morfotipo de folhas coriáceas estreitas e mais alongadas, foi comparada a duas espécies: Simaba cedron (Simaroubaceae) e Chaetocarpus echinocarpus (Euphorbiaceae). Novamente o princípio da exclusão foi empregado, permitindo uma identificação possível como Chaetocarpus echinocarpus, visto que Simaba cedron apresenta margens revolutas, característica não observada em nenhum espécime do morfotipo. $\mathrm{O}$ grau de incerteza é moderado a baixo apenas devido às poucas características que podem ser preservadas em espécies coriáceas.

A família Euphorbiaceae possui 290 gêneros e cerca de 7500 espécies, sendo que 72 gêneros e em torno de 1100 espécies ocorrem no Brasil (Barroso, 1991a). Segundo Joly (1998) os centros de dispersão desta família encontram-se nas Américas e África e possui hábitos bem variados. Apresenta características foliares bastante presentes nos espécimes de Campo Formoso como presença de externas e nervação percorrente, mas o seu reconhecimento nos espécimes fósseis nem sempre é possível devido a grande diversidade presente na família. A espécie Chaetocarpus echinocarpus é registrada na Chapada Diamantina em Lençóis, Seabra e Serra da Chapadinha, Morro do Chapéu, Ituberá, Entre Rios e Santa Cruz da Cabrália em vegetações de restinga, mata ciliar, mata estacional e caatinga. 
O morfotipo 4D não foi identificado por aparentar ser sementes. Os espécimes são bem simétricos com nervura mediana bem visível. Entretanto, existe a possibilidade de serem apenas folhas parcialmente dobradas e mal preservadas, já que não são visiveis outras nervuras.

e) Classes de tamanhos micro I ou II.

Como era previsto, estas classes são bem abundantes no material do herbário. Vegetações abertas ou de climas mais frios e secos tendem a ter folhas menores. Das 153 famílias pesquisadas no herbário, 98 possuem espécies com folhas de tamanhos micro I ou II, mas se considerarmos o total de espécies analisadas, 2228,764 são micro I ou II, representando menos de $50 \%$ da flora.

Esta caracteristica define o morfotipo 5, subdivido em 7 grupos ainda sem identificação.

f) Padrão de nervação actinódromo.

O padrão de nervação actinódromo ocorre mais comumente em climas frios e secos. Nessas condições as folhas tendem a ter dentes e lâmina foliar lobada. Normalmente a lobação do limbo é acompanhado pelo padrão actinódromo, no qual há uma nervura primária para cada lobo. A nervação actinódroma também pode ocorrer em folhas de base cordata, nas quais a regiào basal requer nervuras de maior calibre.

Apenas 18 famílias apresentaram este padrão, embora Malvaceae e Passifloraceae contêm muitas espécies com o primeiro par de secundárias semelhante à primária, o que faz com que aparentem ter nervação actinódroma principalmente no registro fossilífero.
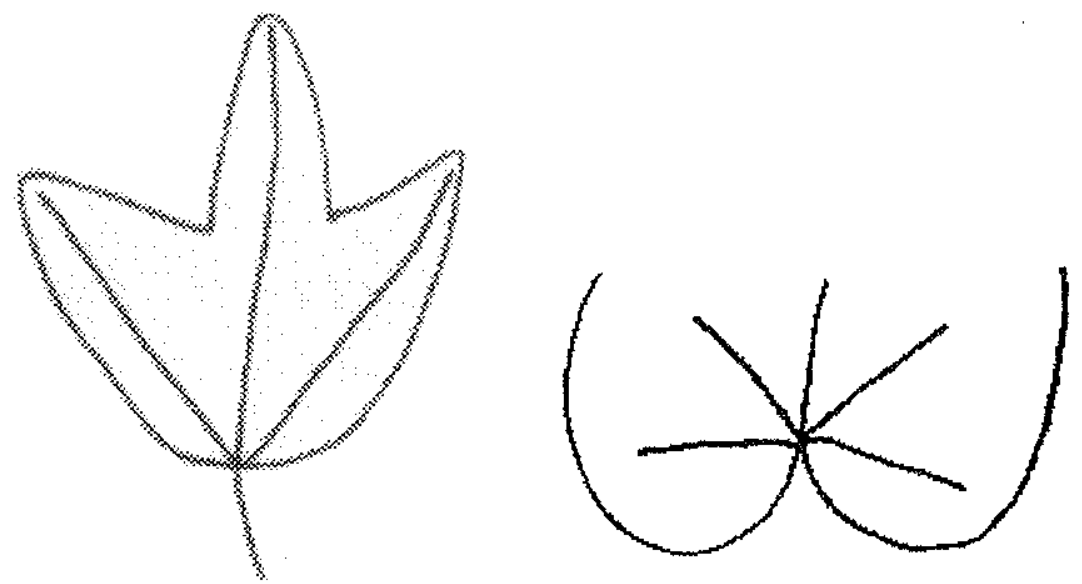

Figura 19 - Folha de limbo lobado e folha de base cordata com nervação actinódroma 
Em Campo Formoso esse padrão está representado pelo morfotipo 6, que pode ser subdividido em três. O morfotipo 6A possui cinco nervuras primárias que se bifurcam originando nervuras secundárias e terciárias. Foi comparada a duas espécies seguindo essas características básicas: Cissampelos andromorpha (Menispermaceae) e Begonia grisea (Begoniaceae).

Estudos mais aprofundados foram realizados com base no material do herbário SPF e pode-se constatar que cinco espécies de Begonia apresentam padrões de nervação muito similares ao morfotipo em questão. Algumas diferenças são notadas como a maior assimetria em $B$. ramentacea, maior lobação do limbo presente em B. paleata e grande tamanho desenvolvido por B. boraceiensis. A ocorrência de um único espécime dificulta a identificação mais segura do morfotipo, sendo que os estudos mostraram que $B$. grisea corresponde a identificação possivel e que as espécies $B$. fellereriana e $B$. convolvulacea, descritas como espécies freqüentes em Lençóis, seja em vegetação de campo rupestre (B. fellereriana) seja na mata de grotão da Serra da Chapadinha, são as espécies mais similares ao morfotipo. Por questões de confiabilidade o morfotipo 6A será considerado como Begonia sp..

A família Begoniaceae é largamente distribuída nos trópicos normalmente com hábito herbáceo mas também arbustivo. Possui 5 gêneros, Barroso et al. (2002) consideram cerca de 500 espécies e Joly (1998) considera cerca de 820 espécies. No Brasil ocorre apenas o gênero Begonia com 168 espécies (Barroso et al., 2002), especialmente comuns nas matas úmidas da Serra do Mar (Joly, 1998). Entretanto, a espécie Begonia grisea foi registrada em vegetação de campos rupestres em Andaraí, Mucugê, na Serra da Chapadinha em Lençóis e na Serra do Tombador em Jacobina. Apesar de não ser tão similar ao morfotipo $6 \mathrm{~A}$, essa espécie possui similaridades também com o morfotipo $6 \mathrm{C}$.

$\mathrm{O}$ morfotipo $6 \mathrm{~B}$ corresponde a morfotipo de menor tamanho foliar, presença de nervação mais densa que a do morfotipo anterior e forma mais orbicular, originada pela fusão de sua base cordada. Foi comparado a Begonia reniformis.

Os estudos realizados no herbário SPF permitiram a comparação com uma segunda espécie: Begonia fischeri. Esta espécie pode atingir 1,2 metros de altura e seus caules são similares a alguns espécimes fósseis que permanecem sem identificação, que já foram tratados como bainha de folhas de monocotiledôneas. Seria possivel, no entanto, que a presença de espécies de Begonia crescendo nas margens do corpo aquoso teria sido suficiente para promover a fossilização das folhas e de alguns de seus caules. 
O morfotipo $6 \mathrm{C}$ apresenta um único espécime fragmentado, mas que possui caracteres suficientes para demonstrar tratar-se de uma espécie de Begonia. Com a complementaçăo dos estudos com o material do herbário SPF foi possivel verificar que tanto pode corresponder a uma terceira espécie de Begonia como ser um espécime dos morfotipos anteriores.

Dois espécimes fósseis de Begonia assim como as fotos que permitiram sua identificação podem ser observados na figura 25 (página 106).

g) Padrão de nervação pinado broquidódromo.

Padrão pinado é caracterizado pela presença de uma única nervação primária, ao contrário do padrão anterior. $O$ padrão de nervação broquidódromo aparenta ser muito comum na vegetação brasileira como um todo e é um padrão de nervação secundária. Ele representa o encontro das nervuras secundárias formando arcos entre si. Em alguns casos ocorre arco de segunda, terceira ou mesmo quarta ordens, formados por nervuras de menor calibre. Este padrão é relativamente comum porque a grande maioria das folhas exibe margem lisa, sem dentes e normalmente são os dentes irrigados com uma nervura. $\mathrm{Na}$ ausência de dentes, o padrão broquidódromo pode ocorrer, assim como o padrão eucamptódromo. No padrão eucamptódromo as nervuras secundárias não formam arcos, mas vão se dividindo gradativamente, tornando-se mais fracas, até não serem mais perceptiveis. $O$ padrão eucamptódromo será comentado no item seguinte.
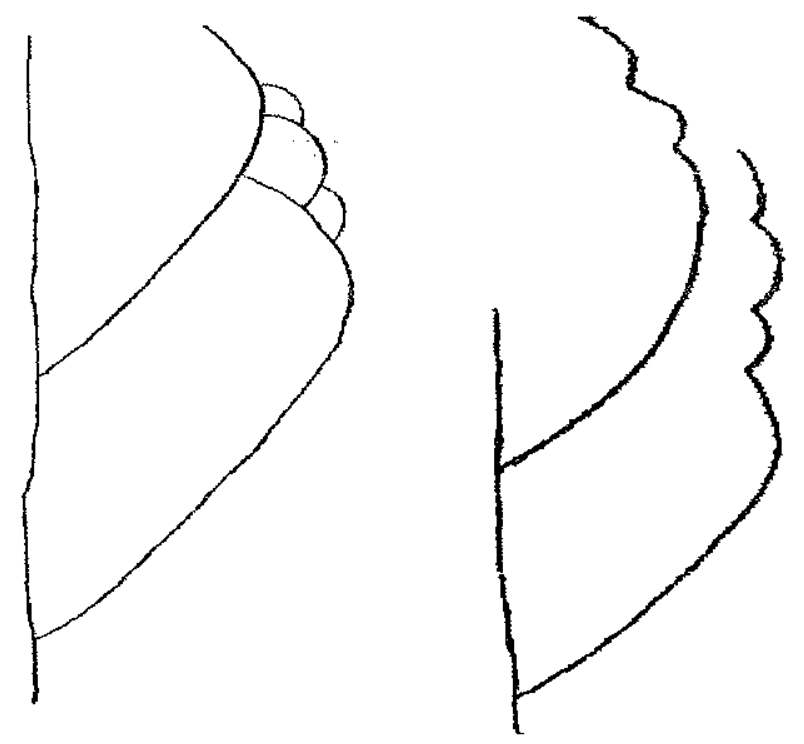

Figura 20 - Ilustração do padrão pinado broquidódromo à esquerda e eucamptódromo à direita 
É importante ressaltar que nem sempre estes dois padrōes são facilmente reconhecidos e há casos em que os dois padrões estão presentes num mesmo espécime, conforme observado em herbário. Considerando que estes padrões serão reconhecidos em material fóssil, cada espécie que apresentava um padrão de dificil definição, broquidódromo ou eucamptódromo ou que possuía ambos os padrões foram adicionadas as duas listas de comparações.

Das 153 famílias pesquisadas, 88 apresentam alguma espécie com nervaçăo broquidódroma, mesmo que em 22 delas só ocorra uma e que 17 familias possuam 2 gêneros e 2 espécies. Parece pouco, mas observando-se o Anexo 1, pode-se notar que algumas familias estão representadas por poucos gêneros e espécies. Maiores detalhes na tabela 9A (páginas 101-103).

A característica de nervação broquidódroma encontra-se presente principalmente no morfotipo 7, que apresenta 5 subdivisões. Por ser uma característica amplamente distribuida e com diferentes padrões de nervação terciária, as comparações ainda não foram bem analisadas.

O morfotipo 7A apresenta margem visivelmente lisa, caracteristica nem sempre bem preservadas nos espécimes de Campo Formoso e ápice agudo. Sua forma pode ser estimada entre oval estreita a elíptica com classe de tamanho variando de Micro III a Meso I. Em relação a sua nervação, a nervura primária é forte e reta, secundárias também de curso retilíneo e terciárias em padrão reticulado ortogonal, chegando a formar nervuras intersecundárias denominadas compostas, por não saírem diretamente da nervura primária e ainda assim poder ser diferenciada da nervação terciária propriamente dita. Sua nervação quaternária é visível, embora não apresente padrão reconhecível. Conforme característica do morfotipo 7, o padrão geral de nervação é broquidódromo e são visíveis arcos de segunda ordem.

A partir de sua riqueza de caracteres, foi possível compará-lo a Prunus sellowii (Rosaceae) e a Vismia latifolia Guttiferae (= Clusiaceae). Tal riqueza de informações ainda não garante identificação muito precisa por ser reconhecidamente um padrão usual de nervação, também presente nas leguminosas, grupo não estudado. Normalmente, porém, as leguminosas apresentam folhas compostas, o que diminui o tamanho de cada folíolo. Considerando-se novamente o princípio de exclusão e que a espécie Vismia latifolia apresenta maior densidade de nervação, totalizando mais de 16 pares de nervuras secundárias, enquanto que os espécimes do morfotipo e Prunus sellowii apresentam em torno de 10 pares de nervuras secundárias além de todo o padrão acima descrito, a mesma está sendo considerada a identificação da espécie com grau moderado a baixo de incerteza. Um espécime fóssil e a espécie que permitiu a identificação estão ilustrados na figura 26 (página 107). 
A familia Rosaceae possui 124 gêneros e aproximadamente 3.500 espécies distribuidas principalmente no Hemisfério Norte. No Brasil ocorrem poucas espécies de Prunus, Rubus e Quillaja (Barroso, 1991a). São plantas de hábito muito variado: ervas anuais, arbustos, subarbustos, trepadeiras ou árvores. Suas folhas podem ser simples ou compostas (Joly, 1998). A espécie Prumus sellowii foi registrada em Santa Cruz da Cabrália e Rio das Contas.

$\mathrm{O}$ morfotipo $7 \mathrm{~B}$ diferencia-se do morfotipo anterior por apresentar ápice obtuso. Seu limbo foliar aparenta se restringir à forma oval estreita. Sua nervura primária é mais larga na base e suas nervuras secundárias são mais densas, totalizando cerca de 14 pares visíveis. Como o grupo anterior, também foi comparado ao mesmo espécime de Vismia latifolia, sendo considerado a identificação da espécie com grau moderado de incerteza em decorrência não somente do acima exposto como também pelo tipo de ápice. Por ser o ápice uma característica mais variável, o mesmo não representa maiores problemas para a caracterização de uma espécie.

A família Guttiferae Juss (= Clusiaceae) possui 49 gêneros tropicais e subtropicais em todo o mundo, com apenas 1 gênero encontrado em região temperada. São cerca de 1.000 espécies, sendo que no Brasil ocorrem 183 espécies em 21 gêneros. São plantas primariamente lenhosas, arbóreas ou arbustivas com folhas inteiras, mas também podem ser ervas anuais ou perenes e mesmo epifitas (; Barroso et al., 2002).

O morfotipo $7 \mathrm{C}$ apresenta nervura primária mais larga e profunda que os morfotipos anteriores. O padrão geral de nervação não é bem preservado, mas o padrão terciário é bem diferente, pois apresenta padrão oblíquo. Há presença de nervuras intersecundárias simples no terço proximal, surgindo intersecundárias compostas a partir do terço médio. Com base na presença dessas características o morfotipo foi comparado a Davilla rugosa (Dilleniaceae), mas o grau de incerteza é muito alto para realizar a identificação. Como comentado, este tipo de padrão é muito disseminado e os espécimes preservados deste morfotipo não preservam a margem foliar, perdendo-se importantes caracteres para comparações.

A família Dilleniaceae possui 12 gêneros e 280 espécies tropicais, sendo que no Brasil ocorrem 5 gêneros e 38 espécies. São árvores, arbustos ou lianas (Barroso et al., 2002). Joly (1998) considera que a familia apresenta nervação foliar peninérvia muito regular e acrescenta ainda que os gêneros mais comuns no Brasil são Davilla e Curatella. A espécie Davilla nugosa foi registrada em Cairu, Caravelas, Ithéus, São Sebastião do Passé, São Desidério e na Chapada Diamantina. As vegetações presentes nestas localidades são variadas incluindo restinga, floresta ombrófila densa e cerrado, podendo indicar 
ampla valência ecológica dessa espécie, que também foi comparada ao morfotipo 14 D conforme sera comentado adiante.

O morfotipo 7D também apresenta nervação terciária diferenciada dos demais morfotipos 7 , apresentando-se em cascata, padrão menos comumente encontrado. Outra diferença refere-se a classe de tamanho Micro II, menor que as dos morfotipos anteriores. O morfotipo foi comparado a Sebastiana brasiliensis (Euphorbiaceae), ocorrendo num bosque inundável da Argentina. Além das características mencionadas, o princípio de exclusão também foi utilizado e a identificação é considerada com pequeno a moderado grau de incerteza. Essa comparação é bem interessante porque a espécie também é registrada em Rio das Contas, Caetité e Lençóis, localidades com campo rupestre e as duas últimas com vegetações na transição da caatinga para o cerrado. Será que se pode supor que a assembléia fóssil estava realmente sujeita a clima mais frio que o atual ? Ou que simplesmente essa espécie é capaz de sobreviver em condições adversas?

$O$ morfotipo $7 \mathrm{E}$ corresponde a um único fragmento preservado, possivelmente da classe de tamanho Micro III, mas que pode ser Meso 1, dependendo da forma foliar. Diferencia-se dos morfotipos 7 anteriores não só pela classe de tamanho mas principalmente por apresentar nervação terciária menos densa formando grandes áreas com bom desenvolvimento da nervação quaternária. Podemse observar arcos de segunda ordem. O morfotipo foi então comparado a Banisteriopsis membranifolia (Malpighiaceae). Não foi registrado nenhum outro espécime dessa espécie no herbário ALCB, além do presente na Mata Atlântica de Uma, embora isto não signifique que a mesma não ocorra em outras regiǒes da Bahia. O fato do espécime ser único e fragmentado acarreta pequeno grau de incerteza nesta identificação, apesar de todos os caracteres mencionados. Um espécime fóssil e a espécie que permitiu a identificação estão ilustrados na figura 26 (página 107).

h) Padrão de nervação pinado eucamptódromo.

A nervação eucampdódroma caracteriza o morfotipo 8 , subdividido em $8 \mathrm{~A}$ e $8 \mathrm{~B}$. O morfotipo $8 \mathrm{~A}$ caracteriza-se por apresentar folhas de classe de tamanho maiores que Micro III, com nervura primária relativamente forte, secundárias sub-opostas $\operatorname{com} \beta$ agudo e curso suave e nervação terciária densa. O morfotipo foi inicialmente comparado a Dioscophora guianensis (Icacinaceae) e a Sloanea dentata (Elaeocarpaceae) que se mostrou mais similar ao morfotipo em questão por apresentar nervação primária mais forte na base, padrão oposto de seis pares de secundárias que pode variar para sub-oposto. Estudos realizados no herbário SPF puderam reconhecer que a familia Icacinaceae exibe, 
em sua maioria, folhas de nervaçăo broquidódroma e indicaram que, de fato, o morfotipo apresenta similaridades com outras espécies de Slonea, como S. guianensis, S. latiflora, S. maximowicziana. S. mitida e $S$ synandra. A caracteristica fragmentada dos espécimes fósseis não permitiu caracteres para a diferenciação entre essas diferentes espécies, mas pode se considerar seguro o reconhecimento do morfotipo como Sloanea sp..

A família Elaeocarpaceae possui 10 gêneros essencialmente tropicais segundo Joly (1998) e 7 gêneros e 125 espécies tropicais sendo que 2 gêneros e 5 espécies ocorrem no Brasil segundo Barroso et al. (2002). Corresponde a uma familia basal com folhas simples e inteiras, sendo que apenas Sloanea, a urucurna da Amazônia, constitui um gênero nativo (Joly, 1998; Barroso et al., 2002).

O morfotipo $8 \mathrm{~B}$ apresenta folhas da classe de tamanho Micro II, nervura primária forte, nervuras secundárias sub-opostas $\operatorname{com} \beta$ obtuso e nervação terciária reticulada ortogonal formando intersecundárias compostas. Foi comparado a Emmotum affine (Icacinaceae) e a Eriope hypenioides (Lamiaceae), sendo esta última admitida como a espécie dada a espessura da nervura primária, a variação no ângulo de emergência das nervuras secundárias e ao padrão de finalização da nervura secundária.

A família Lamiaceae corresponde a uma grande família contendo 200 gêneros e cerca de 3200 espécies cosmopolitas (Joly, 1998) ou contendo 150 gêneros e 2800 espécies entre ervas anuais ou perenes, subarbustos ou arbustos (Barroso 1991b). A espécie Eriope hypenioides foi registrada em Palmeiras, Lençóis, Serra da Chapadinha, Serra do Tombador (Rio das Contas) e em Mucugê em campo rupestre ou na transição de campo rupestre com caatinga ou cerrado.

i) Nervura primária de forte calibre.

Quarenta familias exibiram nervura primária visivelmente de forte calibre, não sendo consideradas as ocorrências que exibem de forte calibre apenas na base foliar. A presença de nervação primária forte caracteriza o morfotipo 9 que foi subdividido em 4. Nas primeiras análises realizadas, considerou-se que os morfotipos $9 \mathrm{~A}$ e $9 \mathrm{C}$ seriam variações da mesma espécie: Terminalia actinophylla (Combretaceae). Infelizmente constatou-se que de trata se espécie exótica e que, portanto, não pode corresponder ao morfotipo da assembléia de Campo Formoso. Novo estudo no herbário SPF foi realizado para completar essa identificação, mas não foi possível reconhecer outra espécie nativa deste gênero similar nem mesmo outro gênero desta família. O morfotipo $9 \mathrm{~A}$ permanece sem identificação. 
O morfotipo 9A representa agrupamento de fácil reconhecimento, pela presença de nervura primária muito forte e peciolo bem marcado, com base cuneada. Sua nervação secundária é oposta ou, no máximo, sub-oposta, de curso bem relilíneo emergindo entre 40 e $60^{\circ}$ aparentando ser acrótona.

O morfotipo 9B também apresenta nervura primária forte e bem delimitada, mas é mais fraca quando comparado ao morfotipo precedente. Sua base não se encontra bem preservada em nenhum espécime, mas aparenta ser mais arredondada, assim como a forma foliar é mais estreita que o morfotipo 9A. A nervação secundária é sub-alterna na base e alterna no terço médio. O ângulo de emergência não representa a inclinação do curso das secundárias. O morfotipo foi inicialmente comparado a Hyptis salzmanni (Lamiaceae). O gênero Hyptis é freqüente nos campos, mas Hyptis salzmanni foi registrado em Mata de São João, município baiano que apresenta cerrado e floresta ombrófila densa.

Para melhores comparações realizou-se estudo com o material do herbário SPF, que possui depositado 120 espécies do gênero Hyptis, enquanto que o herbário ALCB possui 58 espécies. Das 120 espécies do $\mathrm{SPF}$, apenas 26 espécies apresentam folhas muito pequenas ou pequenas a ponto de não serem comparáveis com os espécimes preservados na assembléia fóssil de Campo Formoso. Por observações anteriores incluiu-se neste estudo o gênero Eriope, também da familia Lamiaceae (wabiatae).

Após análise, perceberam-se similaridades entre as espécies de Eriope e de Hyptis com os espécimes do morfotipo 9. Em relação ao morfotipo $9 \mathrm{~B}$, a espécie Eriope salviifolia mostrou-se similar, mas apresenta poucas nervuras no terço basal, ao contrário dos espécimes do morfotipo. A maioria das espécies de Hyptis que apresenta padrão de nervação similar possuem folhas menores e com ângulo de emergência das secundárias no terço basal mais agudo, com exceção da espécie Hyptis lutescens, permitindo identificação ao morfotipo. Fato digno de nota corresponde ao registro desta espécie em Mato Grosso e em São Paulo, cuja morfologia foliar difere da registrada no morfotipo 9B, tendo a mesma sido identificada a partir do espécime proveniente de Correntina, BA, arbusto pequeno em cerrado com floresta de galeria. O espécime em questão pode ser observado na fígura 29.

Durante o processo de identificação um dos espécimes do morfotipo foi exclúdo do mesmo por não apresenta a mesma densidade de nervação na região basal. O espécime em questão, 17-6a, no entanto, não foi comparado a nenhuma espécie por apresentar ângulo de emergência de quase $90^{\circ} \mathrm{e}$ curso das secundárias a $60^{\circ}$. Havia sido considerado variações morfológicas, mas o não registro de tal variação não corroborou a interpretação original. 
O morfotipo $9 \mathrm{C}$, assim como o morfotipo $9 \mathrm{~A}$ apresenta nervura primária muito forte, lalvez até mais forte, a depender da largura de suas folhas, nem sempre bem preservadas. As principais diferenças são encontradas na região basal do limbo foliar. A base foliar, em si, é mais obtusa, mas as nervuras secundárias emergem em ângulo bem agudo e o curso das secundárias altera-se até atingir inclinação semelhante a das nervuras secundárias do terço médio, que são retilineas. Os estudos no herbário SPF permitiram o reconhecimento desse morfotipo como Eriope hypoleuca (Lamiaceae), ocorrente em Grão Mogol, MG com grau baixo a moderado de incerteza. Não houve nenhuma evidência sugerindo que o morfotipo $9 \mathrm{~A}$ corresponda a variações morfológicas do morfotipo $9 \mathrm{C}$. As análises iniciais só reforçam a idèia da necessidade de realizar as comparações com as espécies que ocorrem nas proximidades da regiăo de estudo, porque caso contrário podem ocorrer identificaçòes errôneas.

O morfotipo 9D diferencia-se dos morfotipos 9 anteriores por apresentar folhas menores, da classe de tamanho Micro Il e nervura primária bem forte na base afinando-se para o ápice, ao contrário das anteriores que possuem calibre quase constante durante o seu curso. O morfotipo foi comparado a Jacaranda irwinii (Bignoniaceae). Em decorrência do padrăo comum de nervação e das caracteristicas preservadas considera-se que o grau de incerteza nesta identificação é de moderado a alto.

A família Bignoniaceae é essencialmente tropical, com muitos gêneros e relativamente poucas espécies. São 120 gêneros e 650 espécies, sendo que o Brasil é considerado um centro de dispersão com muitas espécies endêmicas. São lenhosas predominantemente lianas embora possam ser arbóreas ou arbustivas (Barroso 1991 b). A espécie Jacaranda irwinii foi registrada em Palmeiras, Rio do Pires, Andaraí, Mucugê, Piatã, Morro do Chapéu, Miguel Calmon, Lençóis, Rio das Contas e Jacobina, sendo que essas localidades apresentam vegetação de campo rupestre, mata ciliar, mata de grotão ou mata de altitude.

Durante o processo de identificação excluiu-se o espécime 4-9a do morfotipo 9D, optando se por estabelecer o morfotipo 9E. Este único espécime, embora fragmentado, aparenta ter limbo foliar com maiores dimensões e suas nervuras secundárias apresentam curso arqueado, que inicia-se com ângulo maior que $60^{\circ}$ e diminui gradativamente até cursar a cerca de $30^{\circ}$ em relação a nervura primária. O morfotipo foi comparado aos gêneros Eriope e Hyptis. As espécies do gênero Eriope apresentam nervação primária mais forte na região basal e tendência à nervação secundária alterna, não corresponde ao espécime em questã். As espécies do gênero Hyptis apresentam-se mais similares, com calibre da nervura primária mais constante em seu curso, nervação oposta a sub-oposta e $\beta$ amplo. Das espécies mais similares $H$. proteoides e $H$. rubiginosa apresentam nervuras secundárias encurvadas 
muito suavemente; H. lippioides e H. rotumiflora apresentam apenas 4 pares de nervuras no terço basal, de modo que o morfotipo $9 \mathrm{E}$ corresponde à especie $H$. multiflora, registrada no cerrado de Barreiras, BA.

i) Presença da primeira interárea bem mais ampla que as demais

Vinte e duas familias apresentaram esta característica, relativamente comum nas assembléias de Campo Formoso. Essa caracteristica foi utilizada juntamente com outras, não havendo morfotipo especifico para ela, embora esteja muitas vezes associada a presença de nervuras externas.

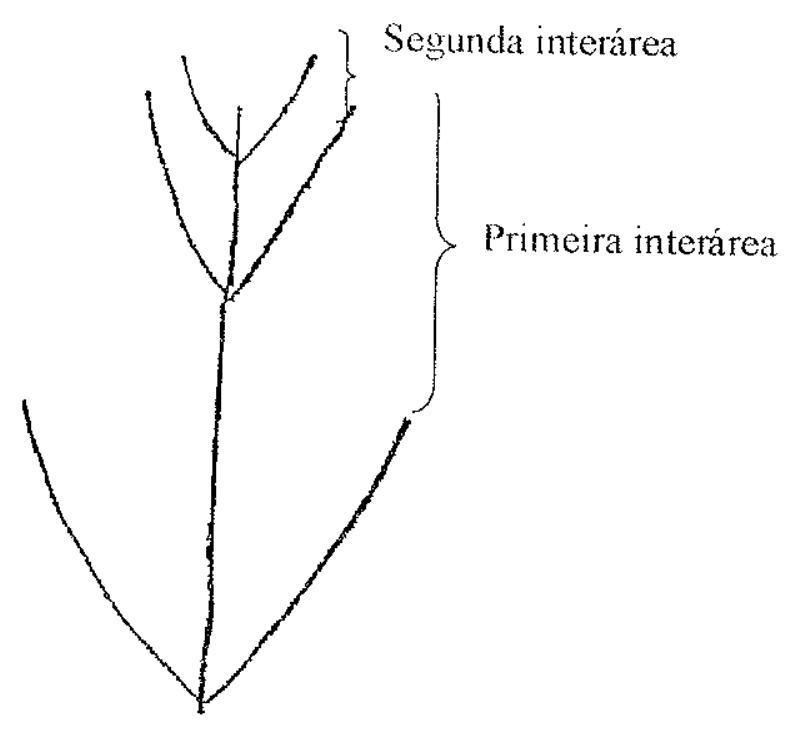

Figura 21 - Ilustração de primeira interárea ampla

1) Presença de nervuras externas.

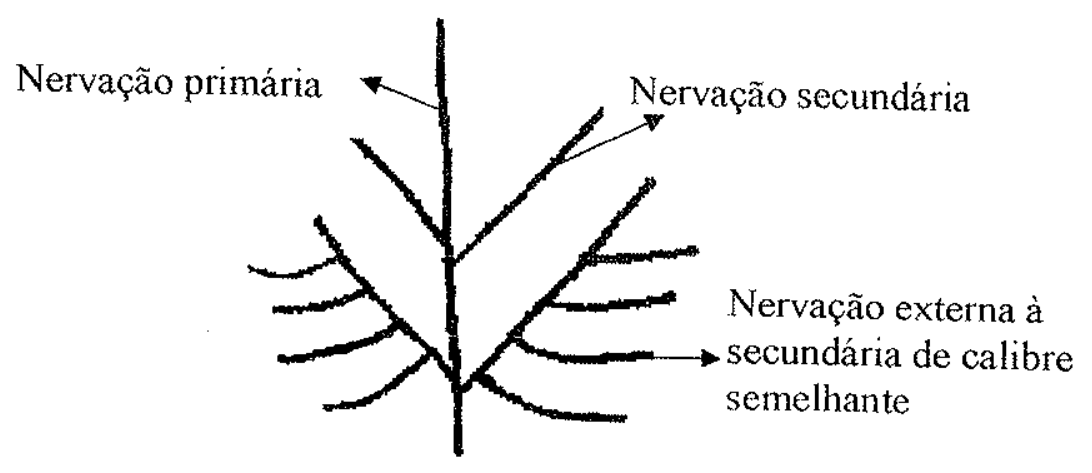

Figura 22 - Ilustração da nervação extema 
A presença de nervuras externas também é característica comum nas associações de folhas de Campo formoso, que é usado para diferenciar alguns grupos dos morfotipos 13 e 14, embora caracterize o morfotipo 10, que se diferencia por não apresentar nervação percorrente. Esse morfotipo é dividido em quatro grupos baseados na nervação secundária alterna ou oposta de curso retilineo ou encurvado. Fragmentos sem o reconhecimento do padrão alterno ou oposto das secundárias permanecem no morfotipo 10 indiferenciado, mas o espécime $22-3 \mathrm{p}$ pode ser identificado a Lundia cordata (Bignoniaceae) baseando-se na amplitude da primeira interárea e no número e curso das nervuras extemas ao primeiro par de secundárias. Outras características de menor relevância mas que auxiliam a identificação corresponde ao tamanho foliar e espessura da nervação. O grau de incerteza nesta identificação está sendo considerado baixo. Ilustrações na figura 35 .

Lundia cordata pode ter como basionimo Bignonia cordata segundo a Veloso (1825-1829). Já foi descrita em remanescentes da Mata Atlântica em Pernambuco, em restingas do Espírito Santo e Rio de Janeiro, matas de dunas litorâneas no Rio Grande do Norte mas também na Caatinga e formações rupestres em Caetité e em cerrado em São Desidério, Bahia.

$\mathrm{O}$ morfotipo $10 \mathrm{~A}$ representa o morfotipo 10 que possui nervuras secundárias opostas e encurvadas. Foi inicialmente comparado a 5 espécies: Fevilea cf. passiflora (Cucurbitaceae), Pavonia luetzelbergii, P. cancellata e Sida micrantha (Malvaceae) e também a Melochia betonifolia (Sterculiaceae), sendo Fevilea cf. passiflora a menos similar e Pavonia cancellata a mais similar, de acordo com o posicionamento das nervuras e forma foliar, mas a identificação não pode ser confirmada nem pelos estudos no herbário SPF. Pavonia cancellata é registrada em Abaeté, Palmeiras, Amélia Rodrigues, Itaberaba, Andarai e Jacobina, em campo rupestre, caatinga arbórea, contato caatinga e mata estacional e em mata ciliar de grotão.

A família Malvaceae possui 88 gêneros e 2300 espécies, sendo que apenas 33 gêneros e 200 espécies ocorrem no Brasil. Apresenta distribuição tropical, subtropical e temperada, principalmente na América do Sul. São ervas, subarbustos, arbustos e raramente árvores, sempre de pequeno porte.

O morfotipo $10 \mathrm{~B}$ apresenta nervuras secundárias opostas e retilíneas e foi inicialmente comparado a Sida micrantha (Malvaceae). Estudos comparativos para confirmação da identificação realizados no herbário SPF indicaram que não seriam possiveis comparações confiáveis. Espécimes de Sida cordifolia (Malvaceae) e de Guazuma ulmifolia (Sterculiaceae) também se mostraram bastante similares. Os poucos caracteres disponíveis dificulta a identificação. Novos estudos seriam necessários para se excluir espécies de Tiliaceae e de Bombacaceae, famílias com padrões de nervações similares. 
apreseritados juntamente com as caracteristicas que os definem, que corresponde respectivamente a classe de tamanho micro I ou II, nervura primária forte e primeira interárea ampla.

O morfotipo 11, caracterizado pelas secundárias alternas, foi subdividido em 5 grupos, baseados principalmente no ângulo e curso das secundárias.

$O$ morfotipo $11 \mathrm{~A}$, caracterizado pelo ângulo de emergência menor que $50^{\circ}$ e curso retilineo, representa grande conjunto de folhas, visto ser um padrão bem comum. Não foi possível a identificação do morfotipo, mas alguns espécimes foram comparados isoladamente. O espécime 4-3a foi comparado a Rollinia sylvatica (Annonaceae) principalmente pela forma do limbo foliar, espessura e curso das nervuras secundárias. Grau moderado de incerteza na identificação, utilizando-se o critério da exclusão.

A família Annonaceae possui 122 gêneros e 1.100 espécies tropicais e subtropicais, embora apenas 36 gêneros sejam americanos, sendo que ocorrem 29 gêneros e 260 espécies no Brasil. Representa uma familia bastante uniforme, sendo constituida de plantas lenhosas arbustivas ou arbóreas, crescendo nos campos ou em florestas (Joly, 1998; Barroso et al., 2002).

O espécime $23-7 \mathrm{c}$ foi comparado a Licania litoralis (Chrysobalanaceae) principalmente pela forma do limbo foliar, espessura e curso das nervuras secundárias. Grau moderado de incerteza na identificação, utilizando-se o critério da exclusão.

A família Chrysobalanaceae possui 12 gèneros e 420 espécies tropicais sobretudo americanos. Sete deles ocorrem no Brasil. São plantas lenhosas arbustivas ou arbóreas (Barroso, 1991a; Joly, 1998). $\mathrm{Na}$ Amazônia e no cerrado ocorrem espécies arbóreas de Licania, conhecida como oiticica. A espécie Licania litoralis foi também registrada em Entre Rios e Itacaré, em Mata Atlântica.

O morfotipo $11 \mathrm{~B}$, possui as mesmas características do grupo anterior, mas o ângulo de emergência é maior que $50^{\circ}$ e menor que $90^{\circ}$, permitindo a comparação a Cabralea sp. (Meliaceae) e a Drymonia coccinea (Gesneriaceae). Trabalhos no herbário SPF permitiram a confirmação da identificação do morfotipo como Drymonia coccinea, baseando-se nas variações morfológicas das duas famílias, excluindo a família Meliaceae. Entretanto, o grau de incerteza é moderado devido aos poucos caracteres preservados no espécime fóssil.

A familia Gesneriaceae possui 140 gêneros e 1.800 espécies tropicais e subtropicais, com alguns representantes temperados na Europa. São plantas herbáceas ou subarbustivas (Barroso, 1991b; Joly, 1998). A maioria vive nas matas, como plantas terrestres ou epífitas, geralmente em ambiente úmido (Barroso, 1991b). 
O morfotipo $11 \mathrm{C}$, possui o ângulo de emergência maior que $50^{\circ}$ e menor que $90^{\circ}$, com secundárias de curso encurvado, sendo comparado a Licania spicata (Chrysobalanaceae) e a Dice/la macroptera (Malpighiaceae) de acordo com os padrões gerais da forma foliar, espessura e curso das nervuras secundárias. Entretanto, os critérios morfológicos são escassos para permitir ao menos o reconhecimento da família, não sendo possivel utilizar o critério da exclusão.

O morfotipo $11 \mathrm{D}$ é bem semelhante ao anterior nas suas características gerais, mas as secundárias são fortemente encurvadas tendo sido identificadas a Centropogon cornutus (Campanulaceae). Ao contrário do morfotipo anterior, estes caracteres morfológicos foram suficientes para o reconhecimento. Mais adiante se pode observar a confirmação desta identificação.

A familia Campanulaceae possui 70 gêneros e 2.000 espécies, temperadas, subtropicais e tropicais segundo Barroso (1991b) e subtropicais e temperadas segundo Joly (1998). São geralmente herbáceas mas também arbustivas. No Brasil ocorre Triodanis, Wahlembergia, ervas comuns nos campos, Centropogon, semitrepadeiras nas matas, Pratia, Lawrentia, Lobetia nos campos e Syphocampylus presente em brejos (Barroso, 1991b; Joly, 1998). A espécie Centropogon cormutus foi registrada em Bonito na Chapada Diamantina, Cairu, Jacobina, Lençóis, Una, Ihéus (BA) e na Mata de Dois Irmãos (PE) e ocorre em praia, mata ciliar, mata de grotão, cerrado, floresta estacional e floresta ombrófila densa.

O morfotipo $11 \mathrm{E}$ embora diferenciado dos demais, com ângulo de emergência das secundárias menor que $50^{\circ}$ de curso inicial retilineo e inclinação posterior, se constitui de um pequeno fragmento, não sendo possivel sua identificação.

O morfotipo 12 é caracterizado pela presença de nervuras secundárias opostas e seus grupos foram definidos baseando-se nos mesmos critérios do morfotipo anterior. $\mathrm{O}$ morfotipo 12A corresponde a um espécime fragmentado impossivel de identificação. Apresenta nervuras secundárias de curso retilíneo emergindo com ângulo menor que $50^{\circ}$.

O morfotipo 12B também apresenta nervuras secundárias de curso retilíneo, mas seus ângulos de emergência são maiores que $50^{\circ}$. A nervura primária possui calibre de médio a fraco. $\mathrm{O}$ único espécime encontra-se mal preservado, podendo ser característica de folha muito membranosa. Apesar dessas feições diagnósticas não foi identificada nenhuma espécie similar durante os trabalhos de herbários.

O morfotipo $12 \mathrm{C}$ apresenta nervura primária relativamente forte e suas secundárias são de curso retilíneo no terço basal e encurvadas no terço apical, com ângulos de emergência menores que $50^{\circ}$. 
Com base nestas características foi comparado a Hirtella cilialc (Chrysobalanaceae), mas o grau de incerteza na identificação é considerado moderado devido aos critérios utilizados. Himella ciliata foi documentada em Jacobina, Lamarão do Passé e Feira de Santana como arbusto em campo rupestre.

O morfotipo 12D representa folhas de classe de tamanho Meso I, com nervuras de calibre relativamente fortes no terço basal. As nervuras secundárias emergem retilineas aproximadamente a $45^{\circ}$ e encurvam-se no terço final. Pelas características gerais o morfotipo foi inicialmente comparado a Byrsonima sericea (Malpighiaceae), a Pouteria scytalophora (Sapotaceae) e a Centropogon cornutus (Campanulaceae) através da mesma foto que identificou o morfotipo $11 \mathrm{D}$. Estudando-se as variações na forma e tamanho do limbo foliar, espessura e curso das nervuras secundárias nos gêneros acima apresentados, pode-se reconhecer o morfotipo como Centropogon comutus.

Foi interessante constatar que de fato os morfotipos $11 \mathrm{D}$ e $12 \mathrm{D}$ pertencem a mesma espécie, sendo o primeiro fragmentos da porção apical da folha, que possui nervação sub-alterna a alterna e o segundo morfotipo fragmentos da porção basal da folha que possui nervação oposta a sub-oposta. A identificação de ambos foi inclusive realizada a partir do mesmo espécime, reforçando esta constatação e confirmando a identificação de ambos os morfotipos.

n) Presença de nervuras terciárias percorrentes.

Esta característica se mostrou relativamente comum, embora com padrões bem diferentes.

No total foram 73 famílias com esta característica de padrão terciário de nervação, no qual as nervuras terciárias vão de uma secundária a outra, normalmente com quaternárias pouco desenvolvidas.

Muitos espécimes de Campo formoso apresentam esta característica e são agrupados nos morfotipos 13 e 14, tendo o morfotipo 13, de nervação percorrente forte, seis subgrupos e o morfotipo 14, com nervaçăo percorrente fraca, sete.

O morfotipo $13 \mathrm{~A}$ caracteriza-se principalmente pela presença de nervação percorrente entre as nervuras externas. No terço basal apresenta nervuras secundárias de forte calibre. Na porção intermediária do limbo as nervuras percorrentes mostram-se em padrão menor regular. Estas características e demais caracteres de forma do limbo foliar, espessura e curso das nervuras secundárias e das externas entre outros, permitiram a identificação como Plukenetia tamnoides (Euphorbiaceae), conforme indica a figura 30. Ela é registrada em Ibicoara, Cachoeira, Feira de Santana, Paramirim e Caetité na Caatinga e na Floresta Estacional. Grau de incerteza é de moderado a baixo apenas pela alta freqüência de alguns caracteres. 


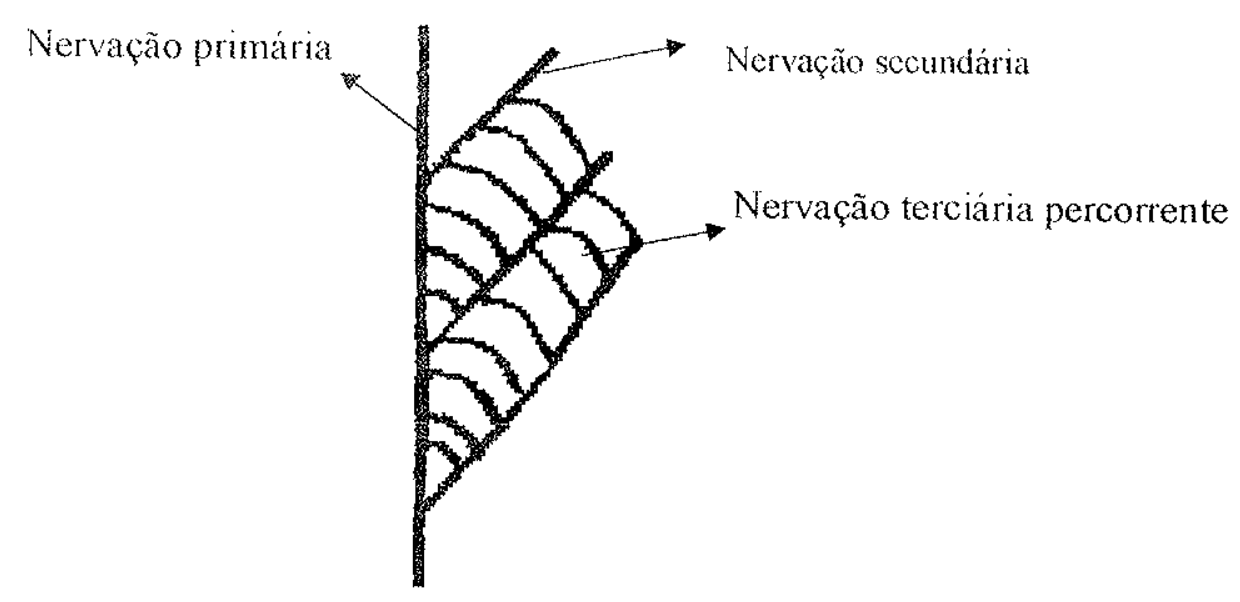

Figura 23 - Ilustração da nervação terciária percorrente

O morfotipo $13 \mathrm{~B}$ diferencia-se do morfotipo anterior por apresentar nervuras primária e secundárias de mesmo calibre e de espessura moderada. O caráter broquidódromo é bem evidenciado, tanto pelas nervuras externas quanto nas nervuras próximas ao ápice. O morfotipo foi comparado a Cordia trichoclada (Boraginaceae) e a Aloysia virgata (Verbenaceae). A disposição das nervuras terciárias percorrentes ao longo do limbo foliar demonstra que o morfotipo não corresponde a Boraginaceae, sendo mais similar a Verbenaceae, mas o padrão das nervuras secundárias não possui correspondência, não sendo possível a identificação do morfotipo.

O morfotipo 13C engloba espécimes muito fragmentados, aparentemente menores que os dois morfotipos precedentes. Suas nervuras externas são visiveis e suas secundárias possuem fraco calibre. O caráter fragmentado dificulta identificação, mas considerando-se a inclusão do espécime 14-1a a este morfotipo, o mesmo estaria identificado como morfotipo $2 \mathrm{~A}$ (Abutilon sp. - Malvaceae).

O morfotipo 13D é caracterizado por apresentar nervação percorrente entre nervações percorrentes, isto é, tanto as nervuras terciátias quanto as quaternátias possuem padrão percorrente. Foi inicialmente comparado a Aloysia virgata (Verbenaceae) e Luehea grandiflora (Tiliaceae). O estudo mais detalhado da nervação quaternária permitiu o reconhecimento do morfotipo como Iuehea grandiflora, embora a ampla ocorrência de alguns caracteres confere grau moderado de incerteza na identificação.

A família Tiliaceae possui 38 gêneros e 420 espécies, sendo 14 gêneros e 65 espécies ocorrentes no Brasil. São árvores, arbustos ou subarbustos (Barroso et al., 2002). A espécie Luehea grandiflora corresponde a uma espécie atlântica, que se estende do nordeste até o estado de São Paulo (Rizzini, 
1997). Condizente com o autor citado, a espécie é registrada na encosta da Serra do Tombador, BA mas também em Abaira em floresta estacional decidual.

O morfotipo $13 \mathrm{E}$ é constituido de quatro espécimes fragmentados mas que tem por característica distintiva nervura secundária de curso sinuoso. Esta característica peculiar e o padrão de nervação percorrente permitiu o reconhecimento do morfotipo como Cordia trichoclada (Boraginaceae), espécie que também apresenta similaridades com o morfotipo 13B. Foi registrada em Salvador e em São Sebastião do Passé, como árvore pouco freqüente ou arbusto ocasional. Grau moderado de incerteza pelo aspecto fragmentado dos espécimes e caracteres comumente encontrados, conforme já comentados para os morfotipos precedentes.

$\mathrm{O}$ morfotipo $13 \mathrm{~F}$ apresenta nervação percorrente relativamente distante permitindo $O$ desenvolvimento de nervação quaternária entre elas, que ao contrário do morfotipo $13 \mathrm{D}$, não é percorrente. Essas características permitiram a identificação com grau moderado de incerteza como Rollinia bahiensis (Annonaceae). Foi registrada em Ilhéus e Una em Mata Atlântica.

O morfotipo 14A apresenta espécimes fragmentados, difícultando as comparações. Possui nervação percorrente fraca em padrão regularmente distribuído, primeira interárea ampla e nervuras externas. Pelas comparações efetuadas com o material do herbário ALCB, foi similar a três espécies: Guazuma ulmifolia (Sterculiaceae), Urena lobata e Sida cordifolia (Malvaceae).

Estudos realizados no herbário SPF indicaram que o morfotipo em questão não seria comparável a Malvaceae pelo fato desta familia não apresentar nervuras externas verdadeiramente perpendiculares à nervura primária. Esta característica pode, no entanto, ser observadas em vários espécimes de Sterculiaceae. Na falta de outras características diagnósticas, o morfotipo só pode ser reconhecido ao nivel de família.

O morfotipo $14 \mathrm{~B}$ apresenta primeira interárea bem ampla e nervuras externas quase perpendiculares à nervura primárias que aparentam formar arcos. Pertence a classe de tamanho Meso 1 . Foi comparado a Aparisthmium cordatum (Euphorbiaceae), mas as observações de todo o material do herbário ALCB pareciam sugerir que o morfotipo 13B juntamente com o morfotipo $14 \mathrm{~B}$ possam corresponder a variações de Apeiba tibouboi (Tiliaceae).

Estudos mais detalhados mostraram que Aparisthmium cordatum representa a identificação do morfotipo com grau moderado de incerteza devido à preservação apenas das bases dos espécimes. Apenas o espécime 16-3a poderia corresponder a variações de Apeiba tibouboi juntamente com os espécimes do morfotipo $13 \mathrm{~B}$, mas que, conforme discutido anteriormente, não apresenta caracteres 
suficientes que permitam a identificação. O especime em questão, o 16-3a é mostrado na figura 31 juntamente com a foto do espécime de Aparisthminm cordatum que permitiu a identificação, podendose observar a semelhança entre ambos, indicando que o morfotipo realmente nào corresponda a Apeiba tibouboi, apesar da possivel semelhança.

O morfotipo $14 \mathrm{C}$ apresenta primeira interárea mais ampla que as demais porém estreita na medida que o ângulo de emergência do primeiro par de secundárias não é obtuso. As nervuras externas acompanham esta tendência, sendo fortemente encurvadas para cima, sem alargamento da base. Após o primeiro par, as nervuras secundárias tomam-se opostas. O morfotipo foi inicialmente comparado a Helicteres sacarolha (Sterculiaceae). No ALCB, entretanto, só havia espécimes provenientes de Goiás e Mato Grosso. Comparações efetuadas no herbário SPF demonstraram o morfotipo apresenta similaridades com outras espécies de Helicteres, como H. aspera, H. guazumaefolia e H. velutina. Desse modo, opta-se por reconhecer o morfotipo apenas como Helicteres sp. (Sterculiaceae) mas com grau baixo de incerteza.

O morfotipo 14D apresenta nervação percorrente fraca e muito próxima entre si. Foi inicialmente comparado a Lippia alnifolia (Verbenaceae) e a Davilla nugosa (Dilleniaceae). O único espécime fragmentado não apresenta características suficientes que permitam a identificaçăo nem mesmo para exclusão de alguma dessas famílias.

O morfotipo 14E é reconhecido como Zizyphus joazeiro (Rhamnaceae), possuindo similaridade surpreendente. A nervação percorrente é fraca, mas de padrão sinuoso e entre elas são visiveis nervação quaternária. Interessantemente só há um espécime neste morfotipo, que pode ser observado na figura 30 (página 111).

A familia Rhamnaceae possui 58 gêneros e 900 espécies de distribuição temperada, subtropical e tropical, sendo pouco representada no Brasil. São árvores de 3 a 20 metros de altura, arbustos, lianas ou subarbustos (Barroso, 1991a).

Zizyphus joazeiro é espécie arbórea, típica do sertão nordestino, embora seja de vegetação secundária de caatinga (Rizzini, 1997). O joazeiro possui folhagem perene, capaz de resistir à longa estiagem do "verão" (Barroso, 1991a). É registrado no Raso da Catarina, Ituaçu, Caetité, Mucugê, Serra do Mulato, Miguel Calmon, Cruz das Almas, Cachoeira, Roncador e Monte Santo.

O morfotipo $14 \mathrm{~F}$ corresponde a apenas um espécime fragmentado, sem possibilidades de identificação. Foi descrito isoladamente por apresentar nervação terciária percorrente associada a outros padrões, sendo, portanto, distinto dos demais. 
O morfotipo $14 \mathrm{G}$ apresenta-se com nervação terciária bastante similar ao do morfotipo $14 \mathrm{~A}$, mas seus espécimes não preservam a regiào basal, dificultando interpretações e mesmo a inclusão no referido morfotipo, já que não é possivel visualizar a primeira interárea ampla ou nervuras externas. Foi inicialmente comparado a (iuazuma ulmifolia (Sterculiaceae) mas sua identificação não é possivel, sendo considerado o alto grau de incerteza na sua inclusão na família Sterculiaceae.

o) Outras características observadas

Presença de nervuras intersecundárias.

Há vários tipos de nervuras intersecundárias, muitas delas decorre do simples encontro de nervuras terciárias reticuladas em padrão ortogonal, originando um tipo de nervura intersecundária descrita neste trabalho como nervura intersecundária composta, para diferenciar das verdadeiras nervuras intersecundárias, que seriam nervuras com calibre das nervuras terciárias que parte diretamente da nervura primária. Em alguns casos, as nervuras secundárias são alternas entre si mas são opostas a intersecundárias. Em outros casos, pode haver tantas intersecundárias que se toma dificil reconhecer a presença das secundárias, que são identificadas apenas pelo seu maior trajeto no limbo foliar. Pode ocorrer também que as intersecundárias tenham calibre intermediário entre as nervuras secundárias e terciárias. A ocorrência encontra-se sintetizada na tabela $9 \mathrm{~B}$.

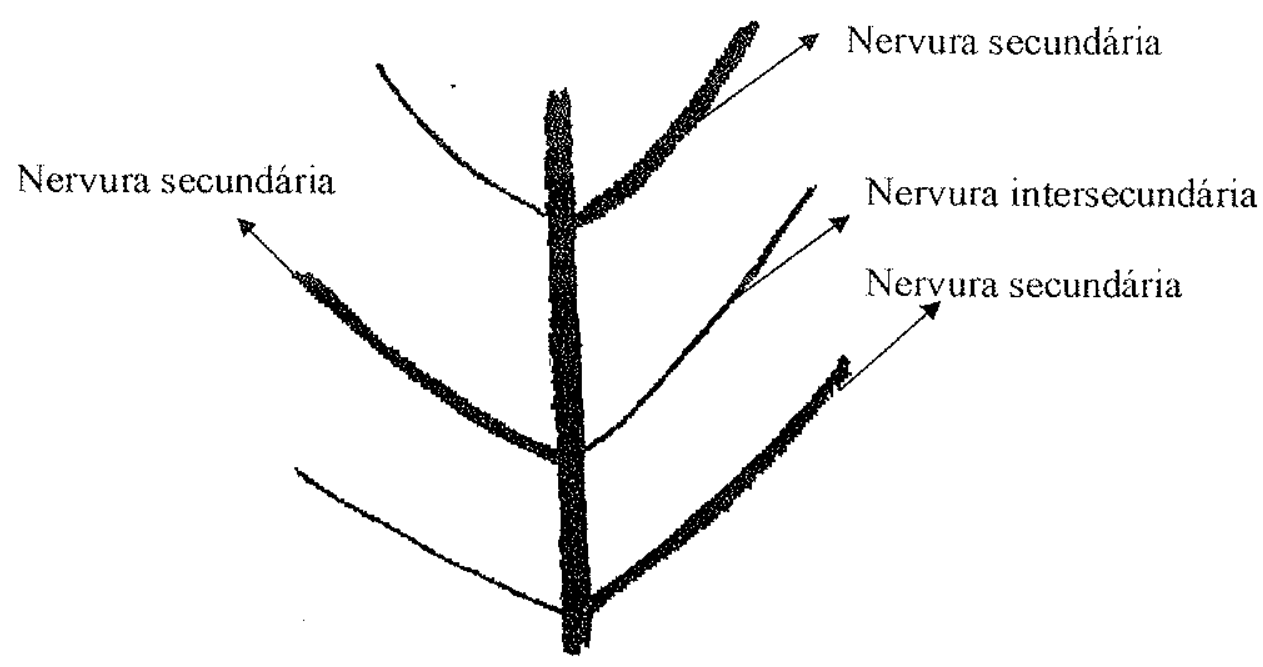

Figura 24 - Ilustração de nervuras secundárias alternas entre si e opostas a intersecundárias. A diferenciação é feita pelo calibre das nervuras. 
A presença desse tipo de nervação facilita a diferenciação de espécimes com padrões de nervação similares.

Densidade de nervação

Embora a densidade da nervação aparentemente possa variar nos diferentes estágios do desenvolvimento de uma folha, a quantidade final de nervuras secundárias ou mesmo de nervuras terciárias é característica relativamente fixa em cada espécie vegetal. Utilizou-se esta característica.

O morfotipo 15 foi definido pela presença de nervação terciária densa e encontra-se subdividido em 5 grupos. Os morfotipos $15 \mathrm{~A}$ e $15 \mathrm{~B}$ só puderam ser identificados com base nos trabalhos realizados no herbário SPF.

O morfotipo $15 \mathrm{~A}$ representa espécimes de forma foliar oval estreita, com nervura primária levemente sinuosa, nervuras secundárias opostas na região basal e alternas na região apical sendo sua distribuição acrótona. São visiveis nervuras terciárias e quaternárias em padrão denso. Não foram encontrados espécimes com tal padrão de nervação durante os trabalhos no herbário ALCB, nem mesmo para comparações iniciais. Sua identificação ocorreu devido aos estudos no herbário SPF com o intuito de confirmar a identificação do morfotipo 16. Pode-se constatar que o morfotipo corresponde a Annona crassiflora (Annonaceae), baseando-se neste padrão denso de nervação. Encontra-se ilustrado na figura 34. O herbário SPF possui registro desta espécie em Formiga, Lagoa Santa, Joaquim Felicio e Grão Mogol, MG; na Chapada do Céu e Mineiros, GO; Chapada do Guimarães, MT; Aurora do Norte, TO; e em Correntina, BA, todas ocorrendo em vegetação de cerrado, seja stricto senstt seja em campos e também em carrascal.

O morfotipo $15 \mathrm{~B}$ possui características semelhantes ao morfotipo $15 \mathrm{~A}$, mas a sua nervaçâo quaternária é mais densa e há muitas terciárias emergindo diretamente da nervura primária. O processo de identificação foi bastante similar ao do morfotipo anterior. Foi identificado como Annona glabra (Annonaceae). O herbário SPF registra esta espécie em Pernambuco, Sergipe, Alagoas e Bahia em diferentes vegetações, mas sempre em locais úmidos.

O morfotipo $15 \mathrm{C}$ apresenta nervação densa com nervuras percorrentes associadas com nervação reticulada, tendo sido inicialmente comparado às espécies Passiflora alata (Passifloraceae), mas que apresenta padrão terciário diferenciado, Sterculia speciosa (Sterculiaceae), apresentando padrão terciário similar ao espécime de Campo Formoso, mas com secundárias com curso mais retilineo e com 
padrão basítono que o espécime fóssil não apresenta e a espécie S/oanea guianensis (Elaeocarpaceae), considerada como a identificação do morfotipo, conforme ilustração da figura 35.

A espécie S\%anea guianensis foi documentada em Palmeiras (1080 metros de altitude), Porto Seguro, Santa Cruz da Cabrália, Lençóis, Ibicoara, Mata de Dois Irmãos em Recife, Pernambuco, em São Paulo e no Pará em Mata Atlântica, mata ciliar, mata de encosta ou em vegetações não informadas.

Estudos realizados no herbário SPF confirmam a identificação do morfotipo. O padrão de nervação é muito similar nas demais espécies do gênero, mas cada espécie possui suas peculiaridades, principalmente em relação a espessura das nervuras mas também em relação ao padrão terciário. As únicas espécies mais similares ao morfotipo, $S$. floribunda, S. latifolia, S. nufa e $S$. synandra, correspondem as espécimes amazônicos, espécies bem menos provável de representar a identificação, mas que por outro lado reforçam a identificação genérica.

O morfotipo 15D é constituído de um único espécime parcialmente fragmentado apresentando secundárias sub-alternas de padrão eucampdódromo e possuindo externas. Nervuras terciárias saindo diretamente da nervura primária. Foi inicialmente comparado a Guazuma ulmifolia (Sterculiaceae) e a Passiflora alata, com o padrão terciário aparenta ser ligeiramente diferente.

Estudos complementares no herbário SPF parecem sugerir que o morfotipo realmente năo corresponda a uma Sterculiaceae, mas sim a espécie Herissantia tiubae (Malvaceae).

O morfotipo $15 \mathrm{E}$ apresenta nervuras intersecundárias propriamente ditas, perpendiculares à nervura primária, presentes em número de três a quatro por cada interárea. Fó inicialmente comparado a espécie Solenostemon monostachyrus (Lamiaceae), mas com poucas similaridades. Os trabalhos no SPF confirmaram esta pequena similaridade. Estudos baseados em diferentes listas de características permitiram a identificação desse morfotipo como Gallesia scorododendron (Phytolacaceae). Por se tratar de outro conjunto de dados, optou-se por estudos comparativos no herbário SPF. Embora este herbário não possua a espécie em questão, as variações morfológicas presentes nas espécies deste gênero são compativeis com o morfotipo, permitindo a confirmação da identificação.

A familia Phytolacaceae possui 17 gêneros pantropicais, com distribuição principalmente nas Américas. São predominantemente herbáceas ou arbustivas, sendo raramente arbóreas. O gênero Gallesia corresponde a árvore de grande porte, considerada padrão de terras férteis, também conhecida como pau-d'alho (Joly, 1998). A espécie Gallesia scorododendron foi registrada em Belmonte, llhéus e Jussari. 
Ângulo de emergência das nervuras secundárias

Conforme já comentado na definição de alguns morfotipos, o ângulo de emergência das secundárias pode ser característica útil na diferenciação de grupos. Esse ângulo normalmente varia entre $50^{\circ}$ e $70^{\circ}$, mas pode ser muito variável. Pode ocorrer também do ângulo de emergencia ser muito pequeno mas o curso da secundária ser em ângulo mais aberto em relação a nervura primária, é o caso do morfotipo 16. Além destas características o morfotipo apresenta forma oboval estreita, nervura primária forte, nervuras secundárias opostas na base tornando se alternas em direção ao ápice, padrão broquidódromo e presença de intersecundárias no terço basal.

O morfotipo 16, no entanto, pode ser considerado como uma variação morfológica de Anmona coriacea (Annonaceae) e identificado através dos trabalhos no herbário SPF. A espécie Annona coriacea foi documentada em Andaraí, Mucugê, Rio das Contas (1340 metros de altitude), Palmeiras, Lençóis, Salvador, Jacobina e São Desidério presentes em campo rupestre, campos gerais e cerrado

A identificação de Annona coriacea não era possivel apenas com os registros do herbário ALCB. Ao analisar o gênero no herbário SPF, constatou-se que não somente o morfotipo 16 correspondia de fato a espécie em questão, como se pode identificar duas outras espécies do mesmo gênero documentadas pelos morfotipos $15 \mathrm{~A}$ e $15 \mathrm{~B}$, conforme comentado anteriormente.

O morfotipo 17, que exibe nervuras secundárias emergindo em ângulo quase reto, inicialmente foi subdividido em 3 , mostrou-se comportar quatro espécies.

O morfotipo $17 \mathrm{~A}$ exibe folhas elípticas com nervura primária larga e rasa, com maior espessamento na base e nervação secundária abundante. Foi inicialmente comparado a três espécies: Brosimum guianensis e B. mubscens (Moraceae) e a Conchocarpus diademates (Rutaceae). Estudandose o padrão de nervação terciária e o curso das nervuras secundárias, pode-se estabelecer, com grau de moderado a baixo de incerteza, que o morfotipo corresponda a Conchocarpus diadematus.

A família Rutaceae possui 150 gêneros e aproximadamente 1.600 espécies tropicais e subtropicais e também em regiões temperadas do Hemisfério Sul. No Brasil são 29 gêneros e 182 espécies. São árvores, arbustos, subarbustos ou ervas (Barroso, 1991a). A espécie Conchocarpus diadematus foi registrada em Cruz das Almas, Jussari e lbicaí em floresta estacional e mata mesófila.

Um dos espécimes originalmente no morfotipo 17A, o 10-1a, apresenta nervura primária de menor calibre e menor densidade de nervuras secundárias e foi identificado isoladamente como Raurolfia brasiliensis (Apocynaceae). Grau moderado de incerteza por si tratar de um único espécime fragmentado. 
A familia Apocynaceae apresenta mais de 2.000 espécies, em 200 gèneros segundo Joly (1998) e em 300 gèneros segundo Barroso (1991b), sendo plantas tropicais e subtropicais, ocasionalmente temperadas, ávores, arbustos, ervas ou trepadeiras. No Brasil ocorrem 41 gêneros e 376 espécies (Barroso, 1991b). Vive tanto nos campos quanto nas matas (Joly, 1998). Folhas geralmente simples sendo que Stipecoma e Peltates apresentam folhas peltadas (Barroso, 1991b). A espécie Ratvolfia brasiliensis foi registrada em Ilhéus e Una, em mata ombrófila densa.

O morfotipo $17 \mathrm{~B}$ possui forma aproximadamente obovada, com nervura primária fraca, sendo identificado como llex psammorpha (Aquifoliaceae) de acordo com a espessura, ângulo de emergência e curso das nervuras secundárias. Grau moderado de incerteza por se tratar de um único espécime fragmentado.

A familia Aquifoliaceae possui três gêneros de larga distribuição nas zonas temperadas segundo Joly (1998) e três gêneros e aproximadamente 450 espécies subtropicais e tropicais segundo Barroso (1991 a). São árvores ou arbustos com folhas perenes e simples. No Brasil ocorrem muitas espécies de Ilex, com folhas pequenas ou bem desenvolvidas, lisas ou com dentes.

O morfotipo $17 \mathrm{C}$ também corresponde a um espécime fragmentado, mas possui caracteristicas únicas: sua nervura primária é extremamente forte, mesmo para a região próxima ao pecíolo e suas secundárias emergem em ângulo reto. É comparado a três gêneros: Protium bahiamum (Burseraceae), Creissomeria nitida (Acanthaceae) e Helicotylis tomentosa (Moraceae). Não há como reconhecer este morfotipo devido a falta de outras características.

O morfotipo 18 apresenta ângulo de emergência das secundárias bem pequeno e as secundárias cursam quase paralelas a nervura primária. A primeira interárea é ligeiramente mais ampla e ocorrem nervuras externas em padrão diferenciado por não expandirem a lâmina foliar com geralmente ocorre. As comparações vieram ressaltar a importância dessas últimas características porque elas foram comparadas, assim como os espécimes do morfotipo 10 a familia Sterculiaceae e Malvaceae. $O$ representante da familia Sterculiaceae é Helicteres guazumaefolia, e o espécime utilizado para a identificação deste grupo foi a Malvaceae Sida cordifolia.

Comparações efetuadas no herbário SPF confirmaram que o morfotipo 18 corresponda a variações morfológicas presentes na espécie Sida cordifolia. Entretanto, outras espécies de Sida, como $S$. caudata, também apresentam tais variações, de modo que se considera mais seguro que o morfotipo seja apenas considerado Sida sp.. 
O morfotipo 19 apresenta feiçǒes particulares ao possuir nervuras secundárias em ângulo quase reto na porção basal da folha, juntamente com nervuras secundárias emergindo com 70 a $80^{\circ}$. Esta característica é observada em nervuras lobadas, conforme demonstra Sterculia striata (Sterculiaceae).

Estudos complementares efetuados no herbário SPF indicaram que nem sempre a espécie Sterculia striata apresenta nervação secundária oposta, embora possa corresponder ao morfotipo em questão. O problema reconhecido, no entanto, refere-se ao caráter fragmentado do fóssil, dificultando o levantamento de todas as características diagnósticas. Foi observado que as nervuras perpendiculares a nervura primária poderia corresponder a nervuras percorrentes simples, podendo ser comparadas a várias outras espécies. O morfotipo foi considerado sem identificação possível.

O morfotipo 20 não apresenta nenhuma característica que o enquadre nos morfotipos anteriores e não foi reconhecido pelas fotos disponiveis do herbário ALCB. O único espécime desse morfotipo apresenta nervura forte na base, que perde identidade em direção apical, as secundárias próximas a base se bifurcam mas não há indicações de nervação broquidódroma, o ângulo de emergência não se altera muito, mas as secundárias possuem cursos mais inclinados em direção ao ápice e a base para ser cordada e/ou assimétrica. Não foi possivel a identificação deste morfotipo.

Considerando-se todas as onze características que permitiram identificação das espécies, houve identificação apenas entre as familias de maior ocomência da característica em questão. Os melhores desempenhos ocorreram entre os representantes com dentes e com presença de percorrentes, seguido de presença de extemas, principalmente pela similaridade de nervação das famílias Malvaceae, Sterculiaceae, Bombacaceae e Tiliaceae. Presença de nervação broquidódroma permitiu a identificação de um morfotipo entre as familias que mais apresentavam a características e dois morfotipos entre as familias nas quais a característica era menos freqüente (tabela $9 \mathrm{~A}$ e $9 \mathrm{~B}$ ). Entretanto, esta organização por características pode vir a ser muito útil na elaboração de chaves dicotômicas que facilitem a identificação de espécies baseando-se apenas em suas características foliares.

Todas as espécies utilizadas para o reconhecimento dos morfotipos encontram-se reunidas em três tabelas: a das espécies que permitiram identificação, a das espécies em estudo e dos espécimes que permitiram a identificação, diferenciando-se da primeira por apresentar somente as características do espécime utilizado e não todas as informações disponíveis sobre aquele táxon. A terceira tabela será utilizado para comparação com os estudos físionômicos. 


\begin{tabular}{|c|c|c|c|}
\hline $\begin{array}{l}\text { Espécie (familia) } \\
\text { Grau de incerteral }\end{array}$ & Localidades & Tipos de vegetação & Morfotipo \\
\hline $\begin{array}{l}\text { Abutilon sp. } \\
\text { (Malvaceac) } \\
\text { Moderado a baixo }\end{array}$ & & & $2 \mathrm{~A} / 1 \mathrm{BC}$ \\
\hline $\begin{array}{l}\text { Alchoomea triplinervia } \\
\text { (Euphorbiaccae) } \\
\text { Moderado }\end{array}$ & $\begin{array}{l}\text { Muito abundante nas matas do sul } \\
\text { do Brasil (Schult\%, 1990). No } \\
\text { herbário ALCB: Jacobina, Lençóis, } \\
\text { Morro do Chapéu, Piatã, Pindobaçu, } \\
\text { Várzea do Poço, Ibirapitanga, Barra } \\
\text { do Mendes, Rio das Contas e Jussari }\end{array}$ & $\begin{array}{l}\text { Espécic atlantica de } \\
\text { restinga (Rizzini, 1997). } \\
\text { Mata ciliar, cerrado e } \\
\text { cerradào. Mais comum na } \\
\text { floresta pluvial atlantica } \\
\text { (Lorenzi, 1992). }\end{array}$ & 100 \\
\hline $\begin{array}{l}\text { Annona coriacea } \\
\text { (Annonaceac) } \\
\text { Muito baixo }\end{array}$ & $\begin{array}{l}\text { Andarai, Mucugê, Salvador, São } \\
\text { Desidério, Jacobina, Rio das Contas, } \\
\text { Palmeiras e Lençóis }\end{array}$ & $\begin{array}{l}\text { Campo rupestre, campos } \\
\text { gerais e cerrado }\end{array}$ & 16 \\
\hline $\begin{array}{l}\text { Annona crasifolia } \\
\text { (Annonaccac) } \\
\text { Muito baixo }\end{array}$ & $\begin{array}{l}\text { Correntina, BA: Chapada dos } \\
\text { Guimarães, Joaquim Felicio, Lagoa } \\
\text { Santa e Formiga, MG; Aurora do } \\
\text { Norte, TO }\end{array}$ & $\begin{array}{l}\text { Ccrrado, campo cerrado e } \\
\text { campo sujo }\end{array}$ & $15 \mathrm{~A}$ \\
\hline $\begin{array}{l}\text { Annona glabra } \\
\text { (Annonaceac) } \\
\text { Muito baixo }\end{array}$ & $\begin{array}{l}\text { Salvador, BA; Santa Luzia do Italu, } \\
\text { SE; Maragogi, AL e Ipojoca, PE }\end{array}$ & $\begin{array}{l}\text { Cerrado, borda de mata e } \\
\text { em alagados }\end{array}$ & $15 B$ \\
\hline $\begin{array}{l}\text { Aparisthmium cordatum } \\
\text { (Euphorbiaceac) } \\
\text { Moderado }\end{array}$ & $\begin{array}{l}\text { Lençóis, Ithéus, ltuberá, Una, } \\
\text { Wenceslau Guimarães, Santa Cruz, } \\
\text { da Cabrália, Eunápolis, Caravelas, } \\
\text { Palmeiras, Jacobina }\end{array}$ & $\begin{array}{l}\text { Floresta ombrófila densa, } \\
\text { Mata Atlântica e floresta } \\
\text { estacional semidecidual }\end{array}$ & $14 \mathrm{~B}$ \\
\hline $\begin{array}{l}\text { Banisteriopsis membranifolia } \\
\text { (Malpighiaceae) - Baixo }\end{array}$ & Una & Mata Atlântica & $7 \mathrm{E}$ \\
\hline $\begin{array}{l}\text { Banisteriopsis stellaris } \\
\text { (Malpighiaceac) } \\
\text { Moderado a baixo }\end{array}$ & $\begin{array}{l}\text { Tucano, Jacobina, Morporá } \mathrm{c} \\
\text { Ribeira do Pombal }\end{array}$ & $\begin{array}{l}\text { Caatinga o campo } \\
\text { rupestre }\end{array}$ & $4 \mathrm{~A}$ \\
\hline $\begin{array}{l}\text { Begonia sp. } \\
\text { (Bcgoniaccac) } \\
\text { Muito baixo }\end{array}$ & $\begin{array}{l}\text { Andaraí, Mucugê, Serra da } \\
\text { Chapadinha em Lençóis e na Serra } \\
\text { do Tombador em Jacobina }\end{array}$ & Campo rupestre & $6 \mathrm{~A} / 6 \mathrm{C}$ \\
\hline $\begin{array}{l}\text { Begonia reniformis ou } B \text {. } \\
\text { fischerii (Begoniacae) } \\
\text { Baico }\end{array}$ & $\begin{array}{l}\text { Cachocira, Santa Cruz da Cabrália, } \\
\text { Serra do Tombador, Ipirá, São } \\
\text { Felipe, Jacobina e Itabuna }\end{array}$ & $\begin{array}{l}\text { Floresta ombróffla densa, } \\
\text { caatinga arbórea densa c } \\
\text { lloresta cstacional }\end{array}$ & $6 B$ \\
\hline $\begin{array}{l}\text { Cecropia saxatilis } \\
\text { (Cecropiaceae) } \\
\text { Baixo }\end{array}$ & $\begin{array}{l}\text { Paraguaçu, Itaête, São Scbastião do } \\
\text { Passe, Lamarão do Passe, Cairú e } \\
\text { Salyador }\end{array}$ & $\begin{array}{l}\text { Floresta ombrófila densa, } \\
\text { floresta estacional e } \\
\text { restinga }\end{array}$ & 1 \\
\hline $\begin{array}{l}\text { Centropogon commutus } \\
\text { (Campanulaceac) } \\
\text { Muito baixo }\end{array}$ & $\begin{array}{l}\text { Cairu, Bonito, Jacobina, Lençóis, } \\
\text { Una, Ihéus e Mata de Dois Imãos, } \\
\text { PE }\end{array}$ & $\begin{array}{ll}\text { Praia, mata ciliar, } & \text { mata } \\
\text { de grotão, cerrado, } & \text { mata } \\
\text { estacional e } & \text { mata } \\
\text { ombrófila densa } & \\
\end{array}$ & $11 \mathrm{D} / 12 \mathrm{D}$ \\
\hline $\begin{array}{l}\text { Chaetocarpus } \\
\text { echinocarpus } \\
\text { (Euphorbiaceac) } \\
\text { Moderado a baixo }\end{array}$ & $\begin{array}{l}\text { Chapada Diamantina em Lençóis, } \\
\text { Seabra, Morro do Chapéu, Ituberá, } \\
\text { Entre Rios e Santa Cruz Cabrália }\end{array}$ & $\begin{array}{l}\text { Restinga, mata ciliar, } \\
\text { mata estacional e caatinga }\end{array}$ & $4 \mathrm{C}$ \\
\hline $\begin{array}{l}\text { Conchocarpus dicadematus } \\
\text { (Rutaccac) } \\
\text { Moderado a baixo }\end{array}$ & Ibicaraí, Cruz das Almas, Jussari & $\begin{array}{l}\text { Mata higrófila periubada } \\
\text { e Mata mesólila }\end{array}$ & $17 \mathrm{~A}$ \\
\hline
\end{tabular}

Tabela 6 - Relação das espécies identificadas aos morfotipos descritos em Campo Formoso, BA 


\begin{tabular}{|c|c|c|c|}
\hline $\begin{array}{l}\text { (cmncins suberosis: } \\
\text { (Connaraccac) } \\
\text { Baixo a moderado }\end{array}$ & São Desidério. Amaxônia & Cerrado. & $4 B$ \\
\hline $\begin{array}{l}\text { Cordia trichoclada } \\
\text { (Boraginaccac) } \\
\text { Moderado }\end{array}$ & Salvador e São Sebastião do Passé & Vegetaçăo nâo informada & $13 E$ \\
\hline $\begin{array}{l}\text { Davilla flexuosa } \\
\text { (Dilleniaceae) } \\
\text { Apenas comparacão }\end{array}$ & $\begin{array}{l}\text { Camaçari, Belmonte, Santa Cruz da } \\
\text { Cabralia e Itapoã. Salvador }\end{array}$ & Dunas e restinga arbórea & $7 \mathrm{C}$ \\
\hline $\begin{array}{l}\text { Drymonia coccinea } \\
\text { (Gesneriaceac) } \\
\text { Baixo }\end{array}$ & Igrapiúna & Mata ciliar & $11 \mathrm{~B}$ \\
\hline $\begin{array}{l}\text { Lriope hypenioides } \\
\text { (Lamiaceac) } \\
\text { Moderado }\end{array}$ & Mucugê e Barra do Estiva & $\begin{array}{l}\text { Subarbusto de } 2 \mathrm{~m} \text { em } \\
\text { mata ciliar, campos gerais } \\
\text { c campo rupestre }\end{array}$ & $8 D$ \\
\hline $\begin{array}{l}\text { Lriope hypolenca } \\
\text { (Lamiaceac) } \\
\text { Baixo a moderado }\end{array}$ & Grão - Mogol e ltacambira, MG & & $9 \mathrm{C}$ \\
\hline $\begin{array}{l}\text { Gallesia scorododendron } \\
\text { (Phytolacaceac) } \\
\text { Baixo }\end{array}$ & Belmonte, Jussari e llhéus & Mata de cabruca & $15 \mathrm{E}$ \\
\hline $\begin{array}{l}\text { Helicteres sp. } \\
\text { (Sterculiaceac) } \\
\text { Muito baixo }\end{array}$ & & & $14 \mathrm{C}$ \\
\hline $\begin{array}{l}\text { Herissantia tiubae } \\
\text { (Malvaceac) } \\
\text { Baixo a moderado }\end{array}$ & Pesqueira, PE & Caatinga degradada & $15 \mathrm{D}$ \\
\hline $\begin{array}{l}\text { Hinclla ciliata } \\
\text { (Chrysobalanaceac) } \\
\text { Moderado }\end{array}$ & $\begin{array}{l}\text { Lamarão do Passe, Jacobina e Feira } \\
\text { de Santana }\end{array}$ & Campo rupestrc & $12 \mathrm{C}$ \\
\hline $\begin{array}{l}\text { Hyptis lutescens } \\
\text { (Lamiaceae) } \\
\text { Baixo }\end{array}$ & $\begin{array}{l}\text { Correntina, BA; Sonora, MT e São } \\
\text { Paulo, SP }\end{array}$ & $\begin{array}{l}\text { Cerrado com loresta } \\
\text { galeria }\end{array}$ & $9 \mathrm{~B}$ \\
\hline $\begin{array}{l}\text { Hyptis muliflora } \\
\text { (Lamiaccae) - Baixo }\end{array}$ & Barreiras & Cerrado & $\begin{array}{c}9 E \\
(4-9 a)\end{array}$ \\
\hline $\begin{array}{l}\text { Ilex psammophila } \\
\text { (Aquifoliaceac) } \\
\text { Moderado }\end{array}$ & Porto Seguro & Mata Atlântica & $17 \mathrm{~B}$ \\
\hline $\begin{array}{l}\text { Jacaranda irwinii } \\
\text { (Bignoniaceae) } \\
\text { Moderado a alto }\end{array}$ & $\begin{array}{l}\text { Palmeiras, Rio do Pires, Andaraí, } \\
\text { Mucugê, Piatã, Morro do Chapéu, } \\
\text { Miguel Calmon, Lençóis, Scrra da } \\
\text { Chapadinha, Rios das Contas, } \\
\text { Jacobina }\end{array}$ & $\begin{array}{l}\text { Mata ciliar, mata de } \\
\text { grotão, mata de altitude e } \\
\text { principalmente campo } \\
\text { rupestre }\end{array}$ & $9 \mathrm{D}$ \\
\hline $\begin{array}{l}\text { Licania litoralis } \\
\text { (Chrysobalanaccac) } \\
\text { Moderado }\end{array}$ & Itacaré, Una e Entre Rios & Mata Atlântica & $\begin{array}{c}11 \mathrm{~A} \\
(23-7 \mathrm{c})\end{array}$ \\
\hline $\begin{array}{l}\text { Luehea grandiflora } \\
\text { (Tiliaceac) } \\
\text { Moderado }\end{array}$ & $\begin{array}{l}\text { Encosta da Serra do Tombador e } \\
\text { Abaira }\end{array}$ & $\begin{array}{l}\text { Espécie allântica (Rizzini, } \\
\text { 1997). Floresta estacional } \\
\text { decidual }\end{array}$ & $13 D$ \\
\hline
\end{tabular}

Tabela 6 (cont) - Relação das espécies identificadas aos morfotipos descritos em Campo Formoso, BA 


\begin{tabular}{|c|c|c|c|}
\hline $\begin{array}{l}\text { Lundia cordata } \\
\text { (Bignoniaceac) } \\
\text { Baino }\end{array}$ & Cacticé, Lençois e São Desidério & $\begin{array}{l}\text { Caatinga, } \\
\text { floresta semidecidual } \quad \mathrm{c} \\
\text { formaçoes rupestres }\end{array}$ & $\begin{array}{c}10 \\
(22-3 p)\end{array}$ \\
\hline $\begin{array}{l}\text { Maylemus cantingarum } \\
\text { (Celastraccac) Baixo }\end{array}$ & $\begin{array}{l}\text { Chapada Diamantina nos mumicípios } \\
\text { de Lençois. Mucuge e Entre Rios }\end{array}$ & $\begin{array}{l}\text { Mata ciliar e campo } \\
\text { rupestre }\end{array}$ & $\begin{array}{c}4 \\
(20-1 j)\end{array}$ \\
\hline $\begin{array}{l}\text { Iavonia cancellata } \\
\text { (Malvaccae) } \\
\text { Apenas comparação }\end{array}$ & \begin{tabular}{lrr} 
Abacté, & Palmeiras, & \multicolumn{2}{r}{ Amćlia } \\
Rodrigues, Campo & Alegre & de \\
Lourdes, Itaberaba, & Andarai & e \\
Jacobina & & \\
\end{tabular} & $\begin{array}{l}\text { Campo rupestre, caatinga } \\
\text { arbórea, contato catinga } \\
\text { e mata estacional e } \mathrm{cm} \\
\text { mata ciliar de grotão }\end{array}$ & $10 \mathrm{~A}$ \\
\hline $\begin{array}{l}\text { Piper tectonilfolia } \\
\text { (Piperaceac) Moderado }\end{array}$ & Lençóis, Serra da Chapadinha & Mata de grotão & $\begin{array}{c}3 \mathrm{~A} \\
(4-5 \mathrm{a})\end{array}$ \\
\hline $\begin{array}{l}\text { Plukenetia tamnoides } \\
\text { (Euphorbiaceac) } \\
\text { Moderado a baixo }\end{array}$ & $\begin{array}{l}\text { Ibicoara, Cachoeira, Feira de } \\
\text { Santana, Paramirim e Cactité }\end{array}$ & $\begin{array}{lll}\text { Caatinga } & \mathrm{c} & \text { floresta } \\
\text { estacional } & & \end{array}$ & $13 \mathrm{~A}$ \\
\hline $\begin{array}{l}\text { Prunuts sellowii } \\
\text { (Rosaceac) Moderado }\end{array}$ & $\begin{array}{l}\text { Santa Cruz da Cabrália e Rio das } \\
\text { Contas }\end{array}$ & $\begin{array}{l}\text { Cerrado } \\
\text { arbóreo }\end{array}$ & $7 \mathrm{~A}$ \\
\hline $\begin{array}{l}\text { Ranvolfia brasiliensis } \\
\text { (Apocynaccac) } \\
\text { Moderado }\end{array}$ & lihcus, Una & Mata ombrólila densa & $\begin{array}{c}17 \mathrm{~A} \\
(10-1 \mathrm{a})\end{array}$ \\
\hline $\begin{array}{l}\text { Rollinia bahiensis } \\
\text { (Annonaceae) } \\
\text { Moderado }\end{array}$ & llhéus e Una & Vegetação não informada & $13 \mathrm{~F}$ \\
\hline $\begin{array}{l}\text { Rollinia sylvatica } \\
\text { (Annonaceac) } \\
\text { Moderado }\end{array}$ & Morro do Chapéu & $\begin{array}{l}\text { Arvore de } 2 \mathrm{~m} \text { em mata } \\
\text { ciliar de campo rupestre }\end{array}$ & $\begin{array}{c}11 \mathrm{~A} \\
(4-3 \mathrm{a})\end{array}$ \\
\hline $\begin{array}{l}\text { Sebastiania brasiliensis } \\
\text { (Euphorbiaceae) } \\
\text { Baixo a moderado }\end{array}$ & Rio das Contas, Cactité, Lençois & $\begin{array}{l}\text { Campo rupestre, transição } \\
\text { caatinga - cerrado }\end{array}$ & $7 \mathrm{D}$ \\
\hline $\begin{array}{l}\text { Sida sp. (Malvaceac) } \\
\text { Muito baixo }\end{array}$ & & & 18 \\
\hline $\begin{array}{l}\text { Sloanea guianensis } \\
\text { (Elacocarpaccac) } \\
\text { Baixo }\end{array}$ & $\begin{array}{l}\text { Lençóis, Palmeiras, lbicoara, Porto } \\
\text { Seguro, Santa Cruz da Cabrália, } \\
\text { Mata de Dois Irmãos, PE; PA, SP }\end{array}$ & $\begin{array}{l}\text { Mata ciliar e mata de } \\
\text { cncosta }\end{array}$ & $15 \mathrm{C}$ \\
\hline $\begin{array}{l}\text { Sloanec sp. } \\
\text { (Elacocarpaceac) } \\
\text { Muito baixo }\end{array}$ & & & $8 \mathrm{~A}$ \\
\hline Sterculiaceac Muito baixo & & & $14 \mathrm{~A}$ \\
\hline $\begin{array}{l}\text { Tetrastylidium brasiliensis } \\
\text { (Olacaceac) } \\
\text { Baixo a moderado }\end{array}$ & Jussari, Serra do Teimoso & Floresta semidecidual & $\begin{array}{c}3 A \\
(23-9)\end{array}$ \\
\hline $\begin{array}{l}\text { Vismia latifolia } \\
\text { (Guttiferae = Clusiaceac) } \\
\text { Moderado }\end{array}$ & $\begin{array}{l}\text { Cairu, Eunápolis, Una, São } \\
\text { Sebastião do Passe, Wenceslau } \\
\text { Guimarães, llhéus. }\end{array}$ & $\begin{array}{l}\text { Mata Allântica, mata } \\
\text { ombrófila densa e mata } \\
\text { ciliar }\end{array}$ & $7 \mathrm{~B}$ \\
\hline $\begin{array}{l}\text { Zizyphus joazeiro } \\
\text { (Rhamnaceae) } \\
\text { Baixo }\end{array}$ & $\begin{array}{l}\text { Raso da Catarina, ltuaçu, Cactité, } \\
\text { Mucugê, Serra do Mulato, Miguel } \\
\text { Calmon, Cruz das Almas, } \\
\text { Cachocira, Roncador e Monte Santo }\end{array}$ & Caatinga & $14 \mathrm{E}$ \\
\hline
\end{tabular}

Tabela 6 (cont) - Relação das espécies identificadas aos morfotipos descritos em Campo Formoso, BA 


\begin{tabular}{|c|c|c|c|}
\hline Especic & Localidades & Tipos de vegetação & Morfotipo \\
\hline $\begin{array}{l}\text { Actinostemum sp. } \\
\text { (Euphorbiaccae) }\end{array}$ & $\begin{array}{l}\text { Campo Formoso, Macajuba, } \\
\text { Morro do Chapé, Itaberaba, } \\
\text { Cachoeira, Wenceslau Guimarães } \\
\text { e Una }\end{array}$ & $\begin{array}{l}\text { Floresta ombrófila densa, } \\
\text { mata ciliar em campo } \\
\text { rupestre, floresta } \\
\text { estacional e carrasco }\end{array}$ & $4 \mathrm{~B}$ \\
\hline $\begin{array}{l}\text { Aloysia virgata } \\
\text { (Verbenaccae) }\end{array}$ & Cachocira c Simões Filho & Floresta ombrófila densa & $13 \mathrm{~B} / 13 \mathrm{D}$ \\
\hline $\begin{array}{l}\text { Apeiba tibourbou } \\
\text { (Tiliaceac) }\end{array}$ & $\begin{array}{l}\text { Entre Rios, Porto Seguro, Miguel } \\
\text { Calmon }\end{array}$ & Caatinga & $13 \mathrm{~B} / 14 \mathrm{~B}$ \\
\hline $\begin{array}{l}\text { Begonia grisea } \\
\text { (Begoniaceac) }\end{array}$ & $\begin{array}{l}\text { Lençóis, Serra da Chapadinha, } \\
\text { Andaraí, Jacobina, Serra do } \\
\text { Tombador e Mucugế }\end{array}$ & Campo rupestre & $6 \mathrm{~A}$ \\
\hline $\begin{array}{l}\text { Brosimum guianensis } \\
\text { (Moraceae) }\end{array}$ & $\begin{array}{l}\text { Santo Amaro, Caravelas, Entre } \\
\text { Rios, Belmonte, Barreiras, São } \\
\text { Desidério c Mata de Dois Irmãos, } \\
\text { PE }\end{array}$ & $\begin{array}{l}\text { Mata de encosta, restinga } \\
\text { e cerrado }\end{array}$ & $17 \mathrm{~A}$ \\
\hline $\begin{array}{l}\text { Brosimum rubescens } \\
\text { (Moraceac) }\end{array}$ & Porto Seguro e Entre Rios & Mata Atlântica & $17 \mathrm{~A}$ \\
\hline $\begin{array}{l}\text { Byrsonima sericea } \\
\text { (Malpighiaceac) }\end{array}$ & $\begin{array}{l}\text { Palmeiras, Santa Cruz da } \\
\text { Cabrália, Una, Mundo Novo, } \\
\text { Riodas Contas, Salvador, Entre } \\
\text { Rios, Andará, Lauro de Freitas, } \\
\text { Mata de São João, e Mata de Dois } \\
\text { Irmãoes, PE }\end{array}$ & $\begin{array}{l}\text { Campo rupestre, mata de } \\
\text { grotão, Mata Atlântica, } \\
\text { restinga c região de dunas }\end{array}$ & $12 \mathrm{D}$ \\
\hline $\begin{array}{l}\text { Cabralea sp. } \\
\text { (Meliaceac) }\end{array}$ & Santa Cruz da Cabrália & Vegetação não informada & $11 \mathrm{~B}$ \\
\hline $\begin{array}{l}\text { Cissampelos andromorpha } \\
\text { (Menispermaceae) }\end{array}$ & São Francisco do Conde & Floresta ombrófila densa & $6 \mathrm{~A}$ \\
\hline $\begin{array}{l}\text { Cordia trichoclada } \\
\text { (Boraginaceae) }\end{array}$ & $\begin{array}{l}\text { Salvador e São Sebastião do } \\
\text { Passé }\end{array}$ & Vegetação não informada & $13 \mathrm{~A}$ \\
\hline $\begin{array}{l}\text { Davilla rugosa } \\
\text { (Dilleniaceac) }\end{array}$ & $\begin{array}{l}\text { Camaçari, Belmonte, Santa Cruz. } \\
\text { da Cabrália c llapoã. Salvador }\end{array}$ & Dunas e restinga arbórea & $14 \mathrm{D}$ \\
\hline $\begin{array}{l}\text { Dioscophora guianensis } \\
\text { (Icacinaccac) }\end{array}$ & $\begin{array}{l}\text { Porto Seguro e Santa Cruz da } \\
\text { Cabrália }\end{array}$ & $\begin{array}{l}\text { Vegetações } \\
\text { informadas }\end{array}$ & $8 \mathrm{~A}$ \\
\hline $\begin{array}{l}\text { Dicella macrotera } \\
\text { (Malpighiaccae) }\end{array}$ & Boa Vista do Tupim (Paraguaçu) & $\begin{array}{ll}\text { Floresta } & \text { estacional } \\
\text { semidecidual }\end{array}$ & $11 \mathrm{C}$ \\
\hline $\begin{array}{l}\text { Emmotum affine } \\
\text { (Icacinaceae) }\end{array}$ & $\begin{array}{l}\text { Santa Cruz da Cabrália, Mata de } \\
\text { São João, Entre Rios, Salvador, } \\
\text { Camaçari, Conde e Cairu }\end{array}$ & Restinga arbórea e dunas & $\begin{array}{c}9 D \\
(4-9 a)\end{array}$ \\
\hline $\begin{array}{l}\text { Fevilea cf passiflora } \\
\text { (Cucurbitaceac) }\end{array}$ & Barra do Rocha & Mata ombrófila densa & $10 \mathrm{~A}$ \\
\hline $\begin{array}{l}\text { Geissomeria nitida } \\
\text { (Acanthaccac) }\end{array}$ & llhéus e Caravelas & $\begin{array}{l}\text { Mata de restinga e mata. } \\
\text { úmida }\end{array}$ & $17 \mathrm{C}$ \\
\hline $\begin{array}{l}\text { Guazuma ulmifolia } \\
\text { (Sterculiaceac) }\end{array}$ & $\begin{array}{l}\text { Desde a Argentina, incluindo MT } \\
\text { e MS. Bahia: Rio das Contas, } \\
\text { Cachoeira, Camaçari, Jacobina, } \\
\text { São Desidério e Miguel Calmon }\end{array}$ & $\begin{array}{l}\text { Mata ombrófila densa, } \\
\text { mata de cncosta, } \\
\text { floresta estacional, } \\
\text { cerrado e campo rupestre. }\end{array}$ & $\begin{array}{l}10 \mathrm{~B} \\
14 \mathrm{~A} \\
14 \mathrm{G} \\
15 \mathrm{D}\end{array}$ \\
\hline $\begin{array}{l}\text { Helicostylis tomenlosa } \\
\text { (Moraceac) }\end{array}$ & $\begin{array}{l}\text { lihéus, Porto Seguro, Belmonte, } \\
\text { Una, Wenceslau Guimarães c } \\
\text { Mata de Dois Irmãos, PE: }\end{array}$ & Floresta ombrófila densa & $17 \mathrm{C}$ \\
\hline
\end{tabular}

Tabela 7 - Relação das espécies comparadas aos morfotipos mas que foram rejeitadas 


\begin{tabular}{|c|c|c|c|}
\hline $\begin{array}{l}\text { Helicteres guazumatoliat } \\
\text { (Stcrculiaceae) }\end{array}$ & $\begin{array}{l}\text { Chapada Diamantina, BA c Três } \\
\text { Lagoas, MS }\end{array}$ & Cerrado & 18 \\
\hline $\begin{array}{l}\text { Helicteres sacarolha } \\
\text { (Sterculiaceac) }\end{array}$ & Goiáis e Mato Grosso & Cerrado & $14 \mathrm{C}$ \\
\hline $\begin{array}{l}\text { Licania spicata } \\
\text { (Chrysobalanaceac) }\end{array}$ & llhéus & Mata pertubada & $12 \mathrm{C} / 11 \mathrm{C}$ \\
\hline $\begin{array}{l}\text { Lippia alnifolia } \\
\text { (Verbenaceae) }\end{array}$ & $\begin{array}{l}\text { Serra da Chapadinha, Palmeiras, } \\
\text { Pico das A Imas e Rio das Contas }\end{array}$ & Campo rupestre & $14 \mathrm{D}$ \\
\hline $\begin{array}{l}\text { Melochia betonifolia } \\
\text { (Sterculiaceac) }\end{array}$ & $\begin{array}{l}\text { Cachocira, Ipacactá, Serra do } \\
\text { Orobozinho }\end{array}$ & $\begin{array}{l}\text { Mata ombrófila densa c } \\
\text { capoeira }\end{array}$ & $10 \mathrm{~A}$ \\
\hline $\begin{array}{l}\text { Passiflora alata } \\
\text { (Passilloraceae) }\end{array}$ & $\begin{array}{l}\text { Conde, Una, São Sebastião do } \\
\text { Passe, Porio Seguro, Prado, } \\
\text { Camaçari e Santa Cruz da } \\
\text { Cabrália }\end{array}$ & $\begin{array}{l}\text { Floresta ombroflia densa, } \\
\text { floresta estacional e } \\
\text { restinga }\end{array}$ & $\begin{array}{l}15 \mathrm{C} \\
15 \mathrm{D}\end{array}$ \\
\hline $\begin{array}{l}\text { Pavonia huetzelbergii } \\
\text { (Malvaceac) }\end{array}$ & $\begin{array}{l}\text { Morro do Chapéu, Serra da } \\
\text { Chapadinha }\end{array}$ & Campo rupestre & $10 \mathrm{~A}$ \\
\hline $\begin{array}{l}\text { Pouteria scytalophora } \\
\text { (Sapotaceac) }\end{array}$ & Entre Rios & Vcgetação não informada & $12 \mathrm{D}$ \\
\hline $\begin{array}{l}\text { Protium bahiensis } \\
\text { (Burscraceae) }\end{array}$ & $\begin{array}{l}\text { Santa Cruz da Cabrália, Cairu e } \\
\text { Mata de São João }\end{array}$ & Restinga arbórea & $17 \mathrm{C}$ \\
\hline $\begin{array}{l}\text { Sida cordifolia } \\
\text { (Malvaceae) }\end{array}$ & $\begin{array}{l}\text { São Sebastião do Passe, Jequié, } \\
\text { Poções, Jacobina, Ruy Barbosa, } \\
\text { Feira de Santana, Cruz das } \\
\text { Almas, Cachocira, Contendas do } \\
\text { Sincorá e Campo Formoso. }\end{array}$ & $\begin{array}{l}\text { Restinga, } \quad \text { loresta } \\
\text { estacional e caatinga }\end{array}$ & $\begin{array}{l}18 \\
14 \mathrm{~A}\end{array}$ \\
\hline Sida micrantha (Malvaceac) & $\begin{array}{l}\text { Feira de Santana, Oliveira dos } \\
\text { Brejinhos, Xique-Xique, Mundo } \\
\text { Novo e Itaberaba }\end{array}$ & $\begin{array}{l}\text { Contato caatinga e } \\
\text { lloresta estacional, campo } \\
\text { sujo e caatinga }\end{array}$ & $\begin{array}{l}10 \mathrm{~A} \\
10 \mathrm{~B}\end{array}$ \\
\hline $\begin{array}{l}\text { Simaba cedron } \\
\text { (Simaroubaccac) }\end{array}$ & $\begin{array}{l}\text { Santa Cruz da Cabrália e } \\
\text { Alagoinhas. }\end{array}$ & $\begin{array}{l}\text { Floresta ombrófila densa, } \\
\text { floresta estacional }\end{array}$ & $4 \mathrm{C}$ \\
\hline $\begin{array}{l}\text { Solenostemon monostachyrts } \\
\text { (Lamiaceae) }\end{array}$ & Nilo Peçanha & Margem de estrada & $15 \mathrm{E}$ \\
\hline $\begin{array}{l}\text { Sterculia speciosa } \\
\text { (Sterculiaceac) }\end{array}$ & Entre Rios e Porto Scguro & $\begin{array}{l}\text { Vegetações nâo } \\
\text { informadas }\end{array}$ & $15 \mathrm{C}$ \\
\hline $\begin{array}{l}\text { Sterculic striata } \\
\text { (Sterculiaceac) }\end{array}$ & $\begin{array}{l}\text { Porto Seguro, Bom Jesus da } \\
\text { Lapa, Santa Maria da Vitória e } \\
\text { São Francisco }\end{array}$ & Mata atlântica e caatinga & 19 \\
\hline $\begin{array}{l}\text { Terminalia actinophylla } \\
\text { (Combretaceac) }\end{array}$ & Ilhéus & Restinga & $9 \mathrm{~A}$ \\
\hline $\begin{array}{l}\text { Temstroemia alnifolia } \\
\text { (Theaceae) }\end{array}$ & $\begin{array}{l}\text { Chapada Diamantina, em Prado, } \\
\text { Andarai, Salvador e Abaíra }\end{array}$ & $\begin{array}{l}\text { Duma, restinga arbórea } \mathfrak{c} \\
\text { campo rupestre }\end{array}$ & $4 B$ \\
\hline $\begin{array}{l}\text { Urena lobata } \\
\text { (Malvaceae) }\end{array}$ & $\begin{array}{l}\text { Picadão, Conde, Barrolândia, } \\
\text { Valença, Simões Filho e nas } \\
\text { dunas do Abacté, Salvador. }\end{array}$ & Floresta ombrófila densa & $14 \mathrm{~A}$ \\
\hline
\end{tabular}

Tabela 7 (cont.) - Relação das espécies comparadas aos morfotipos mas que foram reieitadas 


\begin{tabular}{|c|c|c|c|}
\hline Espécie & Localidade & Vegetação & Morfotipo \\
\hline $\begin{array}{c}\text { Alchoernea triplinemia } \\
\text { (Euphorbiaceae) }\end{array}$ & Serra do Brite, Jacobina. & $\begin{array}{l}\text { Arvore na transição } \\
\text { cerrado para mata } \\
\text { ombrófila densa }\end{array}$ & $10 \mathrm{D}$ \\
\hline $\begin{array}{l}\text { Annona coriacea } \\
\text { (Annonaceae) }\end{array}$ & Rio das Contas & Campo rupestre & 16 \\
\hline $\begin{array}{l}\text { Amnona crasifolia } \\
\text { (Annonaceae) }\end{array}$ & Chapada dos Guimarães, MT & Campo cerrado & $15 \mathrm{~A}$ \\
\hline $\begin{array}{l}\text { Annona glabra } \\
\text { (Annonaceae) }\end{array}$ & Embassaí, Salvador & Praia & $15 \mathrm{~B}$ \\
\hline $\begin{array}{c}\text { Aparisthmium cordatum } \\
\text { (Euphorbiaceae) }\end{array}$ & Lençóis & & 14B \\
\hline $\begin{array}{c}\text { Banisteriopsis membranifolia } \\
\text { (Malpighiaceae) }\end{array}$ & Una & Liana em Mata Atlântica & $7 \mathrm{E}$ \\
\hline $\begin{array}{c}\text { Banisteriopsis stellaris } \\
\text { (Malpighiaceac) }\end{array}$ & Tucano & $\begin{array}{l}\text { Trepadeira volúvel em } \\
\text { caatinga }\end{array}$ & $4 \mathrm{~A}$ \\
\hline $\begin{array}{c}\text { Begonia fischeri } \\
\text { (Begoniaceae) }\end{array}$ & Rio das Contas & $\begin{array}{c}\text { Erva ereta e suculenta } \\
\text { em brejo }\end{array}$ & $6 \bar{B}$ \\
\hline $\begin{array}{l}\text { Begonia reniformis } \\
\text { (Begoniaceae) }\end{array}$ & Ipirá & $\begin{array}{c}\text { Arbusto em mata } \\
\text { estacional }\end{array}$ & $6 \mathrm{~B}$ \\
\hline $\begin{array}{l}\text { Cecropia saxatilis } \\
\text { (Cecropiaceae) }\end{array}$ & Salvador & Area antrópica & 1 \\
\hline $\begin{array}{l}\text { Centropogon comutus } \\
\text { (Campanulaceae) }\end{array}$ & Bonito, Chapada Diamantina & $\begin{array}{c}\text { Arbusto em floresta } \\
\text { estacional }\end{array}$ & $11 \mathrm{D} / 12 \mathrm{D}$ \\
\hline $\begin{array}{l}\text { Chaetocarpus echinocarpus } \\
\text { (Euphorbiaccae) }\end{array}$ & $\begin{array}{c}\text { Serra da Chapadinha, } \\
\text { Lençóis }\end{array}$ & Arvore em mata ciliar & $4 C$ \\
\hline $\begin{array}{c}\text { Conchocarpus diadematus } \\
\text { (Rutaceac) }\end{array}$ & Jussari & Floresta mesófila & $17 \mathrm{~A}$ \\
\hline $\begin{array}{c}\text { Connarus suberosus } \\
\text { (Connaraceae) }\end{array}$ & São Desidério & Subarbusto em cerrado & $4 \mathrm{~B}$ \\
\hline $\begin{array}{l}\text { Cordia trichoclada } \\
\text { (Boraginaceae) }\end{array}$ & Salvador & $\begin{array}{c}\text { Arvore de } 3 \mathrm{~m} \text { em } \\
\text { vegetaçăo secundária }\end{array}$ & $13 \mathrm{E}$ \\
\hline $\begin{array}{l}\text { Davilla flexuosa } \\
\text { (Dilleniaceae) }\end{array}$ & Itapoã, Salvador & Dunas & $7 \mathrm{C}$ \\
\hline $\begin{array}{l}\text { Drymonia coccinea } \\
\text { (Gesneriaceae) }\end{array}$ & Igrapiuna & $\begin{array}{c}\text { Subarbusto em mata ciliar } \\
\text { de floresta ombrófila } \\
\text { densa }\end{array}$ & IIB \\
\hline $\begin{array}{l}\text { Eriope hypenioides } \\
\text { (Lamiaceae) }\end{array}$ & Mucugê & $\begin{array}{l}\text { Subarbusto de } 2 \mathrm{~m} \\
\text { proximo a rio }\end{array}$ & $8 \mathrm{~B}$ \\
\hline $\begin{array}{c}\text { Eriope hypoleuca } \\
\text { (Lamiaceac) }\end{array}$ & Grão - Mogol, MG & & $9 \mathrm{C}$ \\
\hline $\begin{array}{l}\text { Gallesia scorododendron } \\
\text { (Phytolacaceae) }\end{array}$ & Belmonte & $\begin{array}{l}\text { Arvore em mata de } \\
\text { cambruca }\end{array}$ & $15 \mathrm{E}$ \\
\hline $\begin{array}{c}\text { Herissantia tiubae } \\
\text { (Malvaceae) }\end{array}$ & Posqueira, PE & Caatinga degradada & $15 \mathrm{D}$ \\
\hline $\begin{array}{c}\text { Hirtella ciliata } \\
\text { (Chrysobalanaceae) }\end{array}$ & Lamarão do Passe & $\begin{array}{l}\text { Arvore em campo } \\
\text { rupestre }\end{array}$ & $12 \mathrm{C}$ \\
\hline
\end{tabular}

Tabela 8 - Sintese das localidades e vegetações nas quais as espécies utilizadas na comparação com os morfotipos estavam presentes. 


\begin{tabular}{|c|c|c|c|}
\hline $\begin{array}{l}\text { Hyptis lutescens } \\
\text { (Lamiaceae) }\end{array}$ & Correntina & $\begin{array}{l}\text { Arbusto em cerrado com } \\
\text { floresta galeria }\end{array}$ & $9 \mathrm{~B}$ \\
\hline $\begin{array}{l}\text { Hyptis multiflora } \\
\text { (Lamiaceae) }\end{array}$ & Barreiras & Cerrado & $\begin{array}{c}9 \mathrm{E} \\
(4-9 \mathrm{a})\end{array}$ \\
\hline $\begin{array}{l}\text { Ilex psammophila } \\
\text { (Aquifoliaceae) }\end{array}$ & Porto Seguro & Mata Atlântica & $17 \mathrm{~B}$ \\
\hline $\begin{array}{l}\text { Jacaranda irwinii } \\
\text { (Bignoniaceae) }\end{array}$ & Rio do Pires & $\begin{array}{l}\text { Árvore de } 2,5 \mathrm{~m} \mathrm{em} \text { mata } \\
\text { de altitude }\end{array}$ & 9D \\
\hline $\begin{array}{c}\text { Licania litoralis } \\
\text { (Chrysobalanaceae) }\end{array}$ & Una & $\begin{array}{c}\text { Árvore em Mata } \\
\text { Atlântica } \\
\end{array}$ & $\begin{array}{c}11 \mathrm{~A} \\
(23-7 \mathrm{c})\end{array}$ \\
\hline $\begin{array}{l}\text { Luehea grandiflora } \\
\text { (Tiliaceae) }\end{array}$ & Abaíra & $\begin{array}{l}\text { Árvore de } 2,5 \mathrm{~m} \text { em } \\
\text { floresta decidual }\end{array}$ & $13 \mathrm{D}$ \\
\hline $\begin{array}{l}\text { Lundia cordata } \\
\text { (Bignoniaceae) }\end{array}$ & Boqueirão, Lençóis & $\begin{array}{c}\text { Arbusto escandente em } \\
\text { floresta estacional } \\
\text { semidecidual }\end{array}$ & $\begin{array}{c}10 \\
(22-3 p)\end{array}$ \\
\hline $\begin{array}{c}\text { Maytemus cantingarum } \\
\text { (Celastraceae) }\end{array}$ & Entre Rios & $\begin{array}{c}\text { Árvore da Mata } \\
\text { Atlântica }\end{array}$ & $\begin{array}{c}4 \\
(20-1 j)\end{array}$ \\
\hline $\begin{array}{c}\text { Pavonia cancellata } \\
\text { (Malvaceae) }\end{array}$ & Pai Inácio, Palmeiras & $\begin{array}{l}\text { Erva em campos } \\
\text { rupestres }\end{array}$ & $10 \mathrm{~A}$ \\
\hline $\begin{array}{l}\text { Piper tectoniifolia } \\
\text { (Piperaceae) }\end{array}$ & $\begin{array}{c}\text { Serra da Chapadinha, } \\
\text { Lençois }\end{array}$ & $\begin{array}{l}\text { Árvore de } 10 \mathrm{~m} \text { em } \\
\text { mata de grotão }\end{array}$ & $\begin{array}{c}3 \mathrm{~A} \\
(4-5 \mathrm{a})\end{array}$ \\
\hline $\begin{array}{c}\text { Plukenetia tamnoides } \\
\text { (Euphorbiaceae) }\end{array}$ & Caetité & $\begin{array}{l}\text { Trepadeira herbácea } \\
\text { em caatinga }\end{array}$ & $13 \mathrm{~A}$ \\
\hline $\begin{array}{c}\text { Prunus sellowii } \\
\text { (Rosaceae) }\end{array}$ & Rio das Contas & $\begin{array}{l}\text { Árvore de } 4 \mathrm{~m} \text { em } \\
\text { cerrado }\end{array}$ & $7 \mathrm{~A}$ \\
\hline $\begin{array}{c}\text { Rauvolfia brasiliensis } \\
\text { (Apocynaceae) }\end{array}$ & Ilhéus & $\begin{array}{l}\text { Arbusto de } 3 \mathrm{~m} \text { em } \\
\text { mata ombrófila densa }\end{array}$ & $\begin{array}{c}17 \mathrm{~A} \\
(10-1 \mathrm{a})\end{array}$ \\
\hline $\begin{array}{l}\text { Rollinia bahiensis } \\
\text { (Annonaceae) }\end{array}$ & Ilhéus & $\begin{array}{c}\text { Árvore de } 10 \mathrm{~m} \text { em } \\
\text { vegetação secundária }\end{array}$ & $13 \mathrm{~F}$ \\
\hline $\begin{array}{c}\text { Rollinia sylvatica } \\
\text { (Annonaceae) }\end{array}$ & Morro do Chapéu & $\begin{array}{l}\text { Árvore de } 2 \mathrm{~m} \text { em mata } \\
\text { ciliar de campo rupestre }\end{array}$ & $\begin{array}{c}11 \mathrm{~A} \\
(4-3 \mathrm{a})\end{array}$ \\
\hline $\begin{array}{l}\text { Sebastiania brasiliensis } \\
\text { (Euphorbiaceae) }\end{array}$ & Argentina & Bosque inundável & $7 \mathrm{D}$ \\
\hline $\begin{array}{c}\text { Sloanea guianensis } \\
\text { (Elaeocarpaceae) }\end{array}$ & $\begin{array}{l}\text { Morro do Pai Inácio } \\
(1080 \mathrm{~m}), \text { Palmeiras }\end{array}$ & $\begin{array}{l}\text { Árvore de } 7 \mathrm{~m} \text { em mata } \\
\text { de encosta }\end{array}$ & $15 \mathrm{C}$ \\
\hline $\begin{array}{l}\text { Tetrastylidium brasiliensis } \\
\text { (Olacaceae) }\end{array}$ & Serra do Teimoso, Jussari & $\begin{array}{l}\text { Árvore de } 6 \mathrm{~m} \text { em } \\
\text { floresta semidecidual }\end{array}$ & $\begin{array}{c}3 \mathrm{~A} \\
(23-9) \\
\end{array}$ \\
\hline $\begin{array}{l}\text { Vismia latifolia } \\
\qquad \text { (Guttiferae = Clusiaceae })\end{array}$ & Wenceslau Guimarães & $\begin{array}{l}\text { Árvore em mata } \\
\text { ombrófila densa }\end{array}$ & $7 \mathrm{~B}$ \\
\hline $\begin{array}{c}\text { Zizyphus joazeiro } \\
\text { (Rhamnaceae) }\end{array}$ & Morro em Ituaçu & $\begin{array}{c}\text { Árvore na beira da } \\
\text { estrada }\end{array}$ & $14 \mathrm{E}$ \\
\hline
\end{tabular}

Tabela 8 (cont.) - Síntese das localidades e vegetações nas quais as espécies utilizadas na comparação com os morfotipos estavam presentes. 


\begin{tabular}{|c|c|c|c|c|c|c|c|c|}
\hline Família & Dentes & Assimetria & Coriácea & Micro I ou II & Actinódroma & $\begin{array}{l}\text { Broquidódro } \\
\text { ma }\end{array}$ & $\begin{array}{l}\text { Eucampdódro } \\
\text { ma }\end{array}$ & Forte \\
\hline Acanthaceae & & & & $\begin{array}{l}15 \text { spp em } 8- \\
10 \text { gêneros }\end{array}$ & & $\begin{array}{l}\text { até } 14 \text { spp em } \\
6-7 \text { gêneros }\end{array}$ & & $\begin{array}{l}7 \mathrm{spp} \text { em } 7 \\
\text { gêneros }\end{array}$ \\
\hline Anacardiaceae & & & & $\begin{array}{l}14 \text { spp em } 8- \\
10 \text { gêneros }\end{array}$ & & $\begin{array}{l}\text { até } 19 \text { spp em } \\
8-12 \text { gêneros }\end{array}$ & & \\
\hline Annonaceae & & & & & & $\begin{array}{l}\text { até } 19 \text { spp em } \\
8-12 \text { gêneros }\end{array}$ & & \\
\hline Apocynaceae & & $\begin{array}{l}5 \text { spp em } 5 \\
\text { gêneros }\end{array}$ & & \begin{tabular}{|l|}
24 spp em $11-$ \\
13 gêneros
\end{tabular} & & $\begin{array}{l}34 \text { spp em } 19 \\
\text { gêneros }\end{array}$ & $\begin{array}{l}17 \text { spp em } 9 \\
\text { gêneros }\end{array}$ & $\begin{array}{l}27 \text { spp em } 20 \\
\text { gêneros }\end{array}$ \\
\hline Aquifoliaceae & & & & $\begin{array}{l}8 \text { spp em } 1 \\
\text { gênero }\end{array}$ & & $\begin{array}{l}10 \text { spp em } 1 \\
\text { gênero }\end{array}$ & & \\
\hline Asclepiadaceae & & & & $\begin{array}{l}24 \text { spp em } 11- \\
13 \text { gêneros }\end{array}$ & & $\begin{array}{l}\text { até } 19 \text { spp em } \\
8-12 \text { gêneros }\end{array}$ & & \\
\hline Begoniaceae & & & & & identificação & & & \\
\hline Bignoniaceae & & & & \begin{tabular}{|l|}
23 spp em $11-$ \\
13 gêneros
\end{tabular} & & $\begin{array}{l}\text { até } 19 \text { spp em } \\
8-12 \text { gêneros }\end{array}$ & $\begin{array}{l}15 \text { spp em } 12 \\
\text { gêneros }\end{array}$ & $\begin{array}{l}13 \text { spp em } 6 \\
\text { gêneros }\end{array}$ \\
\hline Bombacaceae & & & & $\begin{array}{l}11 \text { spp em } 5 \\
\text { gêneros }\end{array}$ & & $\begin{array}{l}\text { até } 14 \text { spp em } \\
6-7 \text { gêneros }\end{array}$ & & $\begin{array}{l}\text { até } 7 \mathrm{spp} \text { em } \\
5 \text { gêneros }\end{array}$ \\
\hline Boraginaceae & & & & & & $\begin{array}{l}10 \mathrm{spp} \text { em } 2 \\
\text { gêneros }\end{array}$ & $\begin{array}{l}17 \text { spp em } 4 \\
\text { gêneros, } 12 \\
\text { em Cordia }\end{array}$ & $\begin{array}{l}12 \text { spp em } 3 \\
\text { gêneros }\end{array}$ \\
\hline Celastraceae & & & Identificação & & & & & \\
\hline Connaraceae & & & identificação & & & & & \\
\hline Convolvulaceae & & & & $\begin{array}{l}34 \text { spp em } 8- \\
10 \text { gêneros }\end{array}$ & & $\begin{array}{l}15 \text { spp em } 5 \\
\text { gêneros }\end{array}$ & $\begin{array}{l}25 \text { spp em } 11 \\
\text { gêneros }\end{array}$ & \\
\hline Chry sobalanaceae & & & & & & $\begin{array}{l}\text { até } 14 \text { spp em } \\
6-7 \text { gêneros }\end{array}$ & & \\
\hline Cucurbitaceae & & & & & $\begin{array}{l}6 \text { spp em } 5 \\
\text { generos }\end{array}$ & & & \\
\hline Elaeocarpaceae & & & & & & & identificação & \\
\hline Erythroxylaceae & & & & & & $\begin{array}{l}16 \text { ssp em } 1 \\
\text { gênero }\end{array}$ & & \\
\hline
\end{tabular}

Tabela 9A - Número de gêneros e espécies com algumas das características analisadas. 


\begin{tabular}{|c|c|c|c|c|c|c|c|c|}
\hline Familia & Dentes & Assimetria & Coriácea & Micro l ou II & Actinódroma & $\begin{array}{l}\text { Broquidódro } \\
\text { ma }\end{array}$ & $\begin{array}{l}\text { Eucampdódro } \\
\text { ma }\end{array}$ & Forte \\
\hline Euphorbiaceae & $\begin{array}{l}22 \text { spp em } 17 \\
\text { gêneros }\end{array}$ & $\begin{array}{l}12 \text { spp em } 11 \\
\text { gêneros }\end{array}$ & identificação & $\begin{array}{l}43 \mathrm{spp} \text { em } 24 \\
\text { gêneros }\end{array}$ & $\begin{array}{l}8 \text { spp em } 4 \\
\text { gêneros }\end{array}$ & $\begin{array}{l}41 \text { spp em } 26 \\
\text { gêneros } \\
\text { identificação }\end{array}$ & $\begin{array}{l}23 \text { spp em } 19 \\
\text { gêneros }\end{array}$ & $\begin{array}{l}21 \text { spp em } 17 \\
\text { gêneros }\end{array}$ \\
\hline Gesneriaceae & & & & & & & & $\begin{array}{l}\text { até } 7 \text { spp em } \\
5 \text { gêneros }\end{array}$ \\
\hline Guttiferae & & & & & & identificação & & $\begin{array}{l}10 \text { spp em } 8 \\
\text { generos }\end{array}$ \\
\hline Lamiaceae & $\begin{array}{l}42 \text { spp em } 9 \\
\text { gêneros }\end{array}$ & & & $\begin{array}{l}52 \text { spp em } 15 \\
\text { gêneros, } 25 \\
\text { em Hyptis. }\end{array}$ & & $\begin{array}{l}23 \text { spp em } 7 \\
\text { gêneros }\end{array}$ & $\begin{array}{l}29 \text { spp em } 8 \\
\text { gêneros, } 16 \\
\text { em Hyptis } \\
\text { identificação }\end{array}$ & identificação \\
\hline Lauraceae & & & & & & $\begin{array}{l}\text { até } 14 \text { spp em } \\
6-7 \text { gêneros }\end{array}$ & & \\
\hline Lythraceae & & & & $\begin{array}{l}17 \text { spp em } 8- \\
10 \text { gêneros }\end{array}$ & & & $\begin{array}{l}11 \text { spp em } 6 \\
\text { gêneros }\end{array}$ & \\
\hline Malpighiaceae & & identificação & identificação & $\begin{array}{l}57 \text { spp em } 15 \\
\text { gêneros }\end{array}$ & & $\begin{array}{l}82 \mathrm{spp} \text { em } 14 \\
\text { gêneros, mas } \\
52 \text { em apenas } \\
3 \text { gêneros }\end{array}$ & & \\
\hline Malvaceae & $\begin{array}{l}54 \text { ssp em } 13 \\
\text { gêneros } \\
\text { identificação }\end{array}$ & & & $\begin{array}{l}59 \text { spp em } 15 \\
\text { gêneros }\end{array}$ & muitas & $\begin{array}{l}\text { até } 14 \text { spp em } \\
6-7 \text { gêneros }\end{array}$ & $\begin{array}{l}34 \text { spp em } 12 \\
\text { gêtneros, com } \\
15 \text { spp de } \\
\text { Sida }\end{array}$ & \\
\hline Moraceae & & & & & & $\begin{array}{l}\text { até } 19 \text { spp em } \\
8-12 \text { gêneros }\end{array}$ & & $\begin{array}{l}\text { até } 7 \text { spp em } \\
5 \text { gêneros }\end{array}$ \\
\hline Olacaceae & & identificação & & & & & & \\
\hline Passifloraceae & & & & $\begin{array}{l}10 \text { spp em } 1 \\
\text { gênero }\end{array}$ & muitas & $\begin{array}{l}12 \text { spp em } 2 \\
\text { gêneros }\end{array}$ & & \\
\hline Piperaceae & & identificação & & & & & & \\
\hline Rosaceae & & & & & & identificação & & \\
\hline Rutaceae & & & & $\begin{array}{l}21 \text { spp em } 11 \text { - } \\
13 \text { gêneros }\end{array}$ & & $\begin{array}{l}29 \text { spp em } 16 \\
\text { gêneros }\end{array}$ & & \\
\hline
\end{tabular}

Tabela 9A (cont.) - Número de gêneros e espécies com algumas das características analisadas. 


\begin{tabular}{|c|c|c|c|c|c|c|c|c|}
\hline Familia & Dentes & Assimetria & Coriácea & Micro I ou II & Actinódroma & $\begin{array}{l}\text { Broquidódro } \\
\mathrm{ma}\end{array}$ & $\begin{array}{l}\text { Eucampdódro } \\
\text { ma }\end{array}$ & Forte \\
\hline Sapindaceae & & & & $\begin{array}{l}10 \text { spp em } 8- \\
10 \text { gêneros }\end{array}$ & & $\begin{array}{l}\text { até } 14 \text { spp em } \\
6-7 \text { gêneros }\end{array}$ & & $\begin{array}{l}\text { até } 7 \text { spp em } \\
5 \text { gêneros }\end{array}$ \\
\hline Sapotaceae & & & $\begin{array}{l}10 \text { spp em } 4 \\
\text { gêneros }\end{array}$ & $\begin{array}{l}17 \text { spp em } 5 \\
\text { gêneros }\end{array}$ & & $\begin{array}{l}14 \text { spp em } 4 \\
\text { gêneros }\end{array}$ & & \\
\hline Scruphulariaceae & & & & $\begin{array}{l}12 \text { spp em } 11 \\
\text { gêneros }\end{array}$ & & & & \\
\hline Solanaceae & $\begin{array}{l}17 \text { spp em } 4 \\
\text { gêneros }\end{array}$ & & & $\begin{array}{l}36 \text { spp em } 11- \\
13 \text { gêneros }\end{array}$ & & $\begin{array}{l}53 \text { spp em } 16 \\
\text { gêneros } \\
\text { sendo } 26 \mathrm{em} \\
\text { Solanum }\end{array}$ & $\begin{array}{l}18 \text { spp em } 7 \\
\text { gêneros, } \\
\text { sendo } 10 \text { em } \\
\text { Solanum }\end{array}$ & \\
\hline Sterculiaceae & & & & & & $\begin{array}{l}\text { até } 14 \text { spp em } \\
6-7 \text { gêneros }\end{array}$ & & \\
\hline Tumeraceae & $\begin{array}{l}26 \text { spp em } 2 \\
\text { gêneros }\end{array}$ & & & $\begin{array}{l}27 \text { spp em } 2 \\
\text { gêneros }\end{array}$ & & & $\begin{array}{l}23 \text { spp em } 2 \\
\text { gêneros }\end{array}$ & \\
\hline Verbenaceae & $\begin{array}{l}19 \text { spp em } 6 \\
\text { gêneros }\end{array}$ & $\begin{array}{l}4 \text { spp em } 2 \\
\text { gêneros }\end{array}$ & & $\begin{array}{l}19 \text { spp em } 8- \\
10 \text { gêneros }\end{array}$ & & & $\begin{array}{l}19 \text { spp em } 6 \\
\text { gêneros }\end{array}$ & $\begin{array}{l}12 \text { spp em } 5 \\
\text { gêneros }\end{array}$ \\
\hline $\begin{array}{l}\text { até } 10 \text { spp em } 3 \\
\text { a } 5 \text { gêneros }\end{array}$ & & & & & & 12 & 8 & \\
\hline $\begin{array}{l}\text { até } 8 \text { spp em } 1 \\
\text { ou } 2 \text { gêneros }\end{array}$ & & & & & & & 10 & \\
\hline $\begin{array}{l}\text { até } 7 \text { spp em } 1 \\
\text { gênero }\end{array}$ & & & & & 4 & 13 & & \\
\hline $6-8$ espécies & & & & 17 & & & & \\
\hline 4-5 espécies & & 3 & & 8 & & & & \\
\hline $\begin{array}{l}3-4 \text { espécies em } \\
\text { até } 3 \text { gêneros }\end{array}$ & & & 7 & & & & 8 & 8 \\
\hline 3 espécies & & & & & 3 & & & \\
\hline $\begin{array}{l}2 \text { espécies em } 1 \\
\text { ou } 2 \text { gêneros }\end{array}$ & 11 & 10 & 9 & 19 & & 17 & 7 & 11 \\
\hline I espécie & 14 & 12 & 20 & 32 & 7 & 22 & 18 & 10 \\
\hline $\begin{array}{l}\text { Total de } \\
\text { familias }\end{array}$ & 47 & 28 & 35 & 98 & 18 & 88 & 62 & 40 \\
\hline
\end{tabular}

Tabela $9 \mathrm{~A}$ (cont.) - Número de gêneros e espécies com algumas das características analisadas. 


\begin{tabular}{|c|c|c|c|c|c|c|}
\hline Familia & $\begin{array}{l}\text { interárea } \\
\text { ampla }\end{array}$ & externas & alterna & oposta & percorrentes & intersecundárias \\
\hline Annonaceae & & & identificação & & identificação & \\
\hline Apocynaceae & & & $\begin{array}{l}6 \text { ssp em } 6 \\
\text { gêneros }\end{array}$ & $\begin{array}{l}5 \text { spp em } 2 \\
\text { gêneros }\end{array}$ & & $\begin{array}{l}13 \text { spp en } 11 \\
\text { gêneros }\end{array}$ \\
\hline Asclepiadaceae & & & & & & $\begin{array}{l}7 \text { spp em } 6 \\
\text { gêneros }\end{array}$ \\
\hline Bignoniaceae & & identificação & & & 14 spp em 7 gêneros & \\
\hline Boraginaceae & & & & & $\begin{array}{l}24 \text { spp em } 5 \text { gêneros, } \\
19 \text { em Cordia } \\
\text { identificação }\end{array}$ & \\
\hline Campanulaceae & & & identificação & identificação & & \\
\hline Chrysobalanaceae & & & identificação & identificação & & \\
\hline Convolvulaceae & & $\begin{array}{l}18 \text { spp em } 7 \\
\text { gêneros }\end{array}$ & & & 20 spp em 7 gêneros & \\
\hline Euphorbiaceae & & $\begin{array}{l}11 \text { spp em } \\
10 \text { gêneros } \\
\text { identificação }\end{array}$ & $\begin{array}{l}14 \text { spp em } 14 \\
\text { gêneros }\end{array}$ & & $\begin{array}{l}30 \text { spp em } 24 \text { gêneros } \\
\text { identificação }\end{array}$ & \\
\hline Gesneriaceae & & & identificação & & & \\
\hline Lamiaceae & & & & & 23 spp em 6 gêneros & \\
\hline Malpighiaceae & & & & & 34 spp em 8 gêneros & $\begin{array}{l}36 \text { spp em } 7 \\
\text { gêneros }\end{array}$ \\
\hline Malvaceae & $\begin{array}{l}15 \text { spp em } 9 \\
\text { gêneros }\end{array}$ & $\begin{array}{l}53 \text { spp em } \\
15 \text { gêneros }\end{array}$ & & $\begin{array}{l}4 \text { spp em } 4 \\
\text { gêneros }\end{array}$ & $\begin{array}{l}39 \text { spp em } 16 \text { gêneros } \\
\text { (identificação) }\end{array}$ & \\
\hline Passifloraceae & & & & & II spp em I gênero & \\
\hline Rhamnaceae & & & & & identificação & \\
\hline Rutaceae & & & & & & $\begin{array}{l}21 \text { spp em } 14 \\
\text { gêneros }\end{array}$ \\
\hline Solanaceae & & & $\begin{array}{l}8 \text { spp em } 5 \\
\text { gêneros }\end{array}$ & & 35 spp em 12 gêneros & $\begin{array}{l}22 \text { spp em } 7 \\
\text { gêneros }\end{array}$ \\
\hline Sterculiaceae & & $\begin{array}{l}11 \text { spp en } 7 \\
\text { gêneros }\end{array}$ & & & $\begin{array}{l}15 \text { spp em } 8 \text { gêneros } \\
\text { identificação }\end{array}$ & \\
\hline Tiliaceae & & & & & identificação & \\
\hline
\end{tabular}

Tabela 9B - Número de gêneros e espécies com as demais características analisadas. 


\begin{tabular}{|c|c|c|c|c|c|c|}
\hline Familia & $\begin{array}{l}\text { interárea } \\
\text { ampla }\end{array}$ & externas & altema & oposta & percorrentes & intersecundárias \\
\hline Turneraceae & & & & & 11 spp em 2 gêneros & \\
\hline Verbenaceae & & & $\begin{array}{l}9 \text { spp em } 6 \\
\text { gêneros }\end{array}$ & & 28 spp em 7 gêneros & \\
\hline $\begin{array}{l}\text { até } 11 \text { spp em } 3 \text { a } \\
5 \text { gêneros }\end{array}$ & 5 & 4 & & & 11 & 12 \\
\hline $\begin{array}{l}\text { até } 13 \text { spp em } 5 \text { a } \\
6 \text { gêneros }\end{array}$ & & & & & 5 & \\
\hline $\begin{array}{l}\text { até } 6 \text { espécies em } \\
1 \text { ou } 2 \text { gêneros }\end{array}$ & & & & & 9 & 10 \\
\hline $\begin{array}{l}3-4 \text { espécies em } \\
\text { até } 3 \text { gêneros }\end{array}$ & & & & 3 & & \\
\hline $\begin{array}{l}2-7 \text { espécies em } \\
\text { até } 5 \text { gêneros }\end{array}$ & & & 20 & & & \\
\hline $\begin{array}{l}2 \text { espécies em } 1 \\
\text { ou } 2 \text { gêneros }\end{array}$ & 4 & 4 & & 11 & 16 & 10 \\
\hline 1 espécie & 12 & 16 & 30 & 20 & 19 & 19 \\
\hline Total de famílias & 22 & 34 & 50 & 36 & 73 & 56 \\
\hline
\end{tabular}

Tabela 9B (cont.) - Número de gêneros e espécies com as dema is características analisadas. 


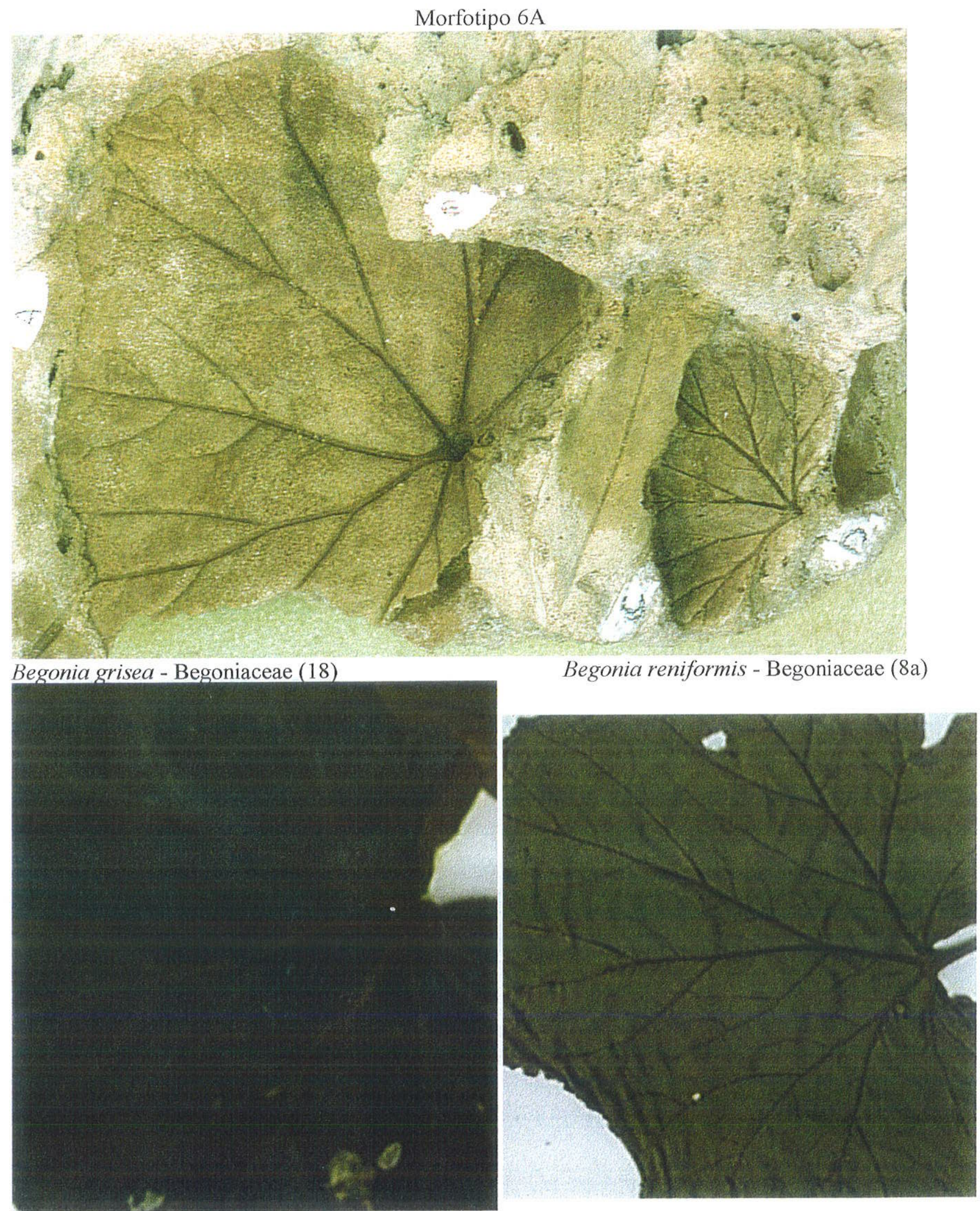

Figura 25 - Foto da amostra 18-5 mostrando dois espécimes do morfotipo 6 identificados pelas fotos abaixo. 

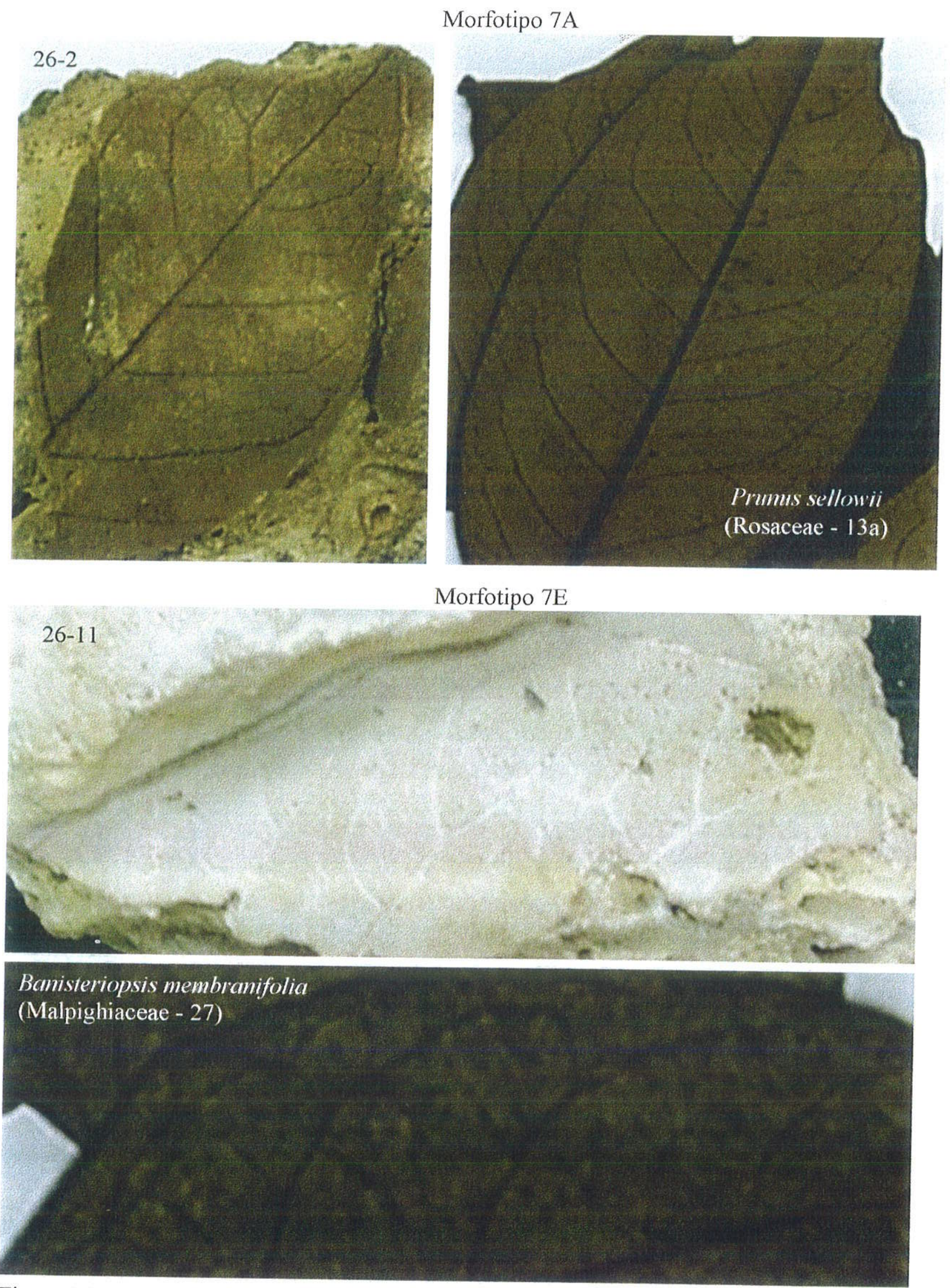

Figura 26 - Fotos das amostras 26-2 e 26-11 com espécimes do morfotipo 7 identificados pelas fotos abaixo dos mesmos. 

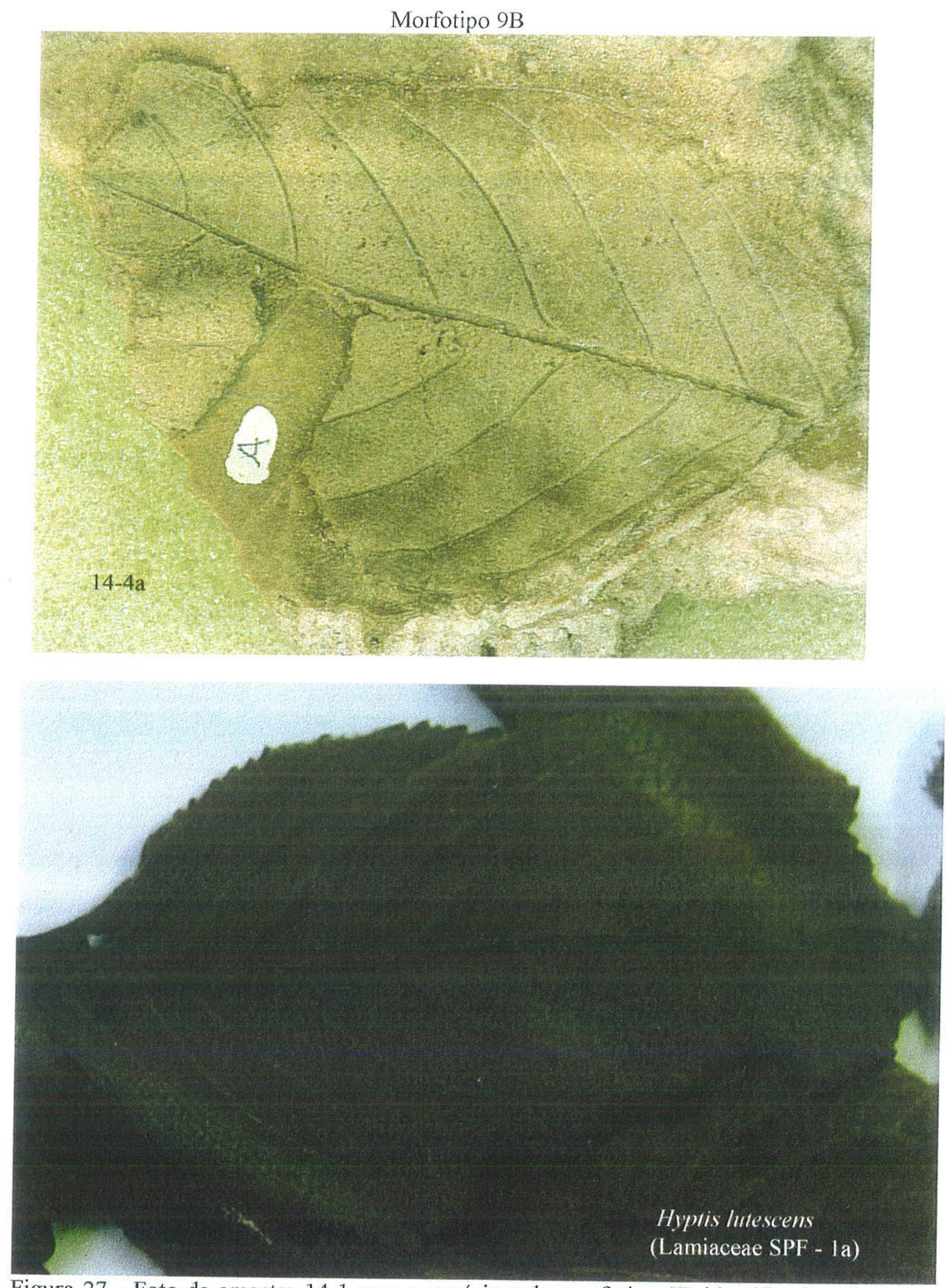

Figura 27 - Foto da amostra 14-1 com o espécime do morfotipo 9B identificado pela foto abaixo do mesmo. 
Morfotipo 13A
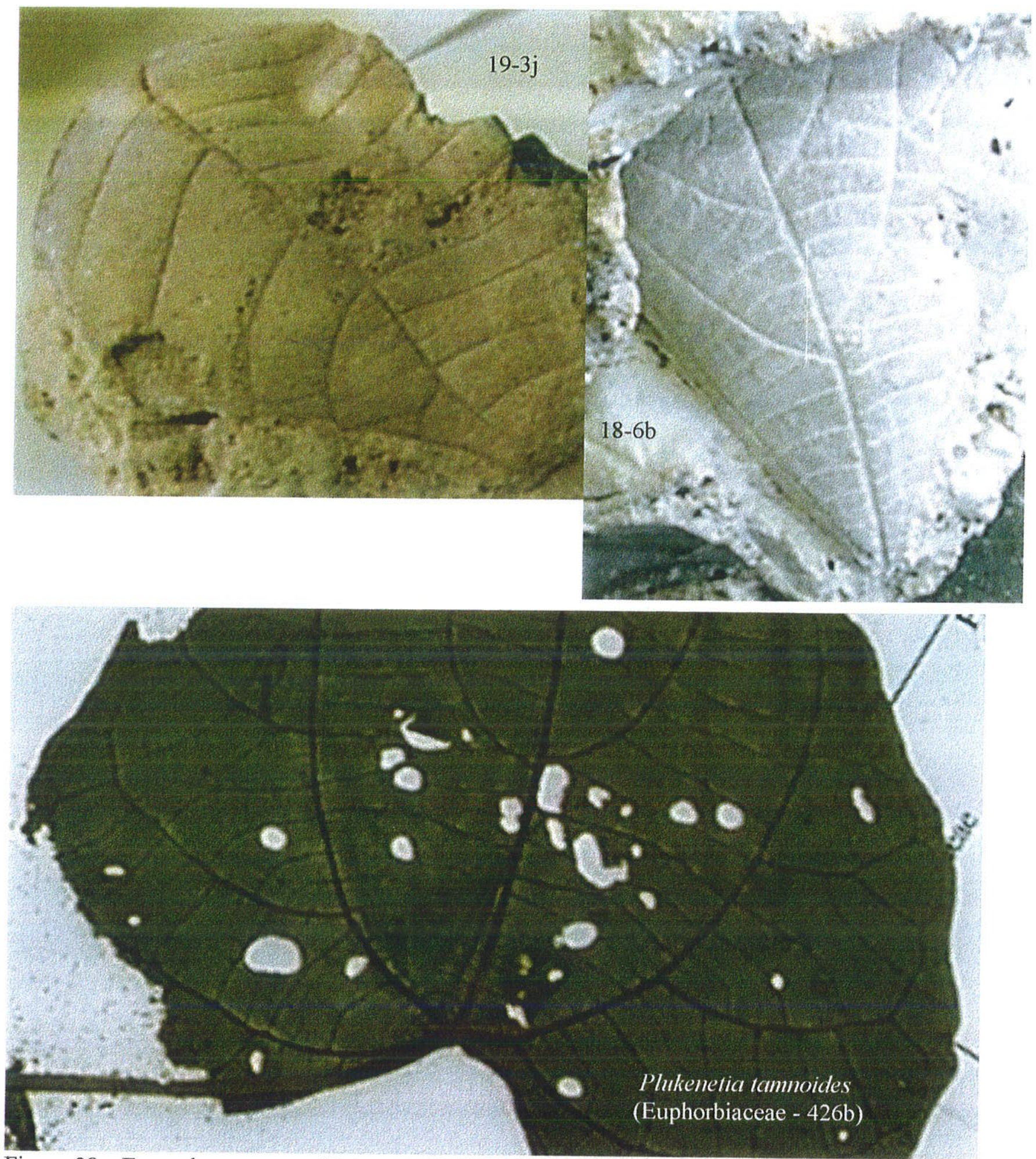

Figura 28 - Fotos das amostras 19-3 e 18-6 com espécimes do morfotipo 13A identificado pela foto abaixo das mesmas. Observar a fragmentação dos espécimes. Há outros espécimes fragmentados, mas não é possível garantir um grau baixo de incerteza na identificação. 


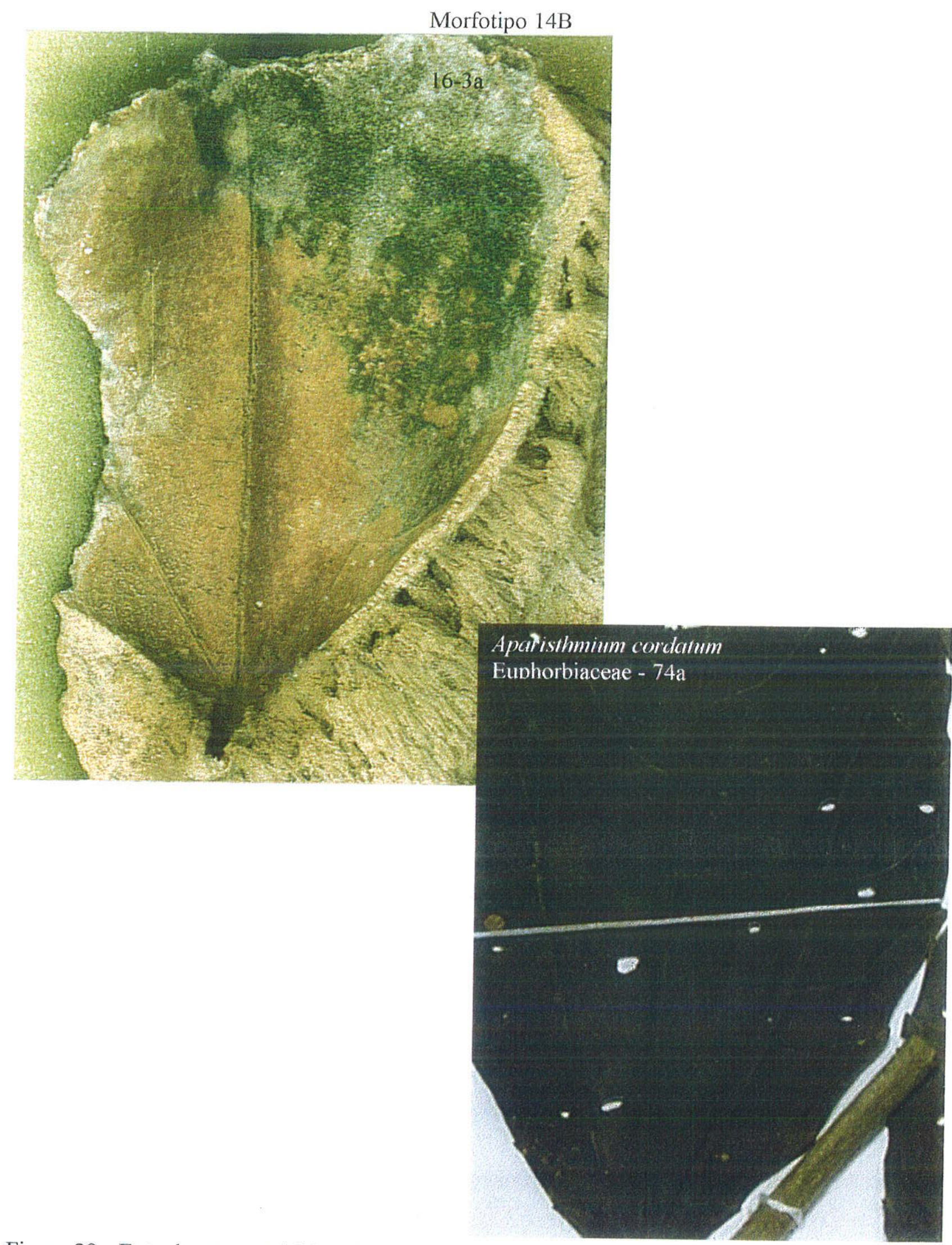

Figura 29 - Foto da amostra 16-3 com o espécime do morfotipo 14B identificado pela foto ao lado do mesmo. 
Morfotipo 14E
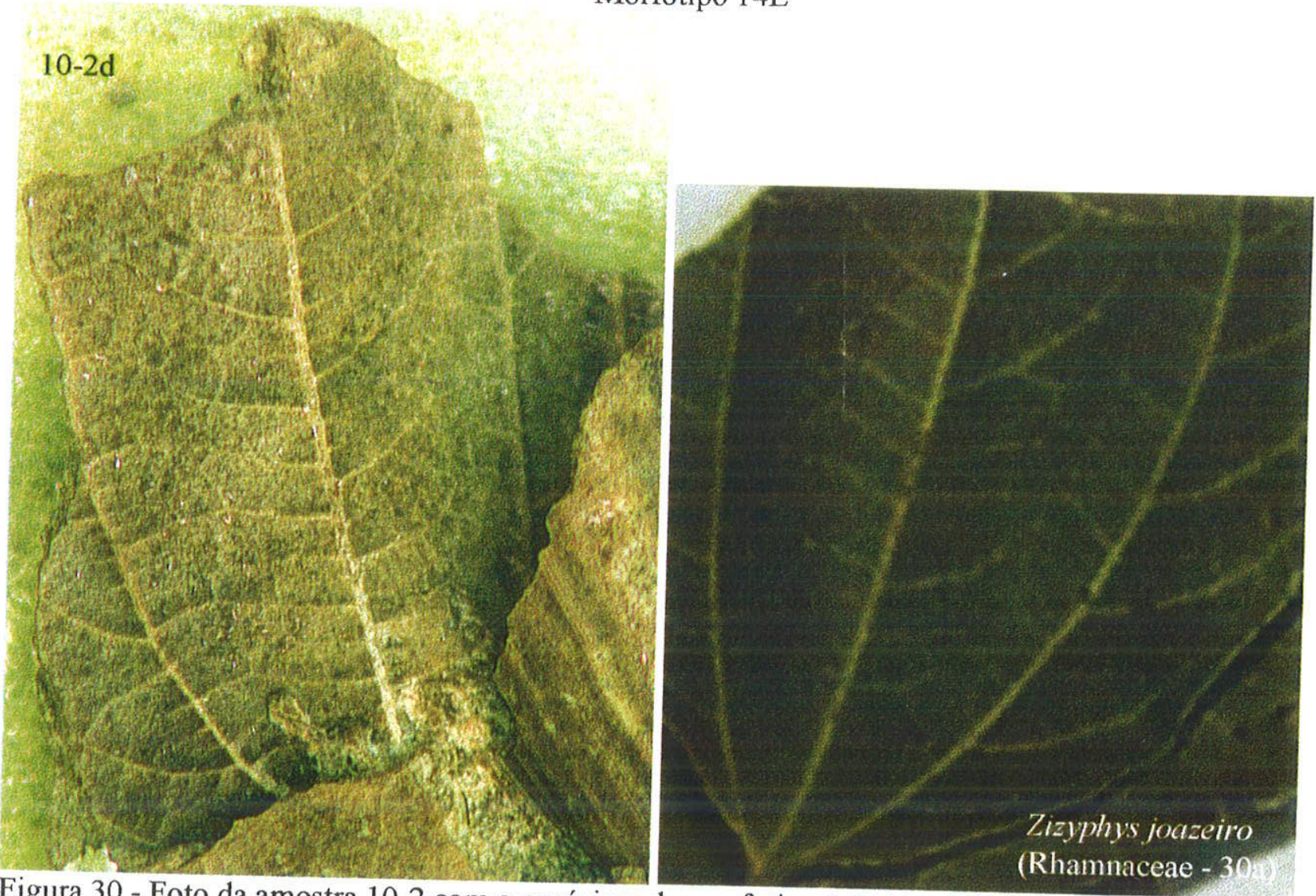

Figura 30 - Foto da amostra 10-2 com o espécime do morfotipo 14E identificado pela foto ao lado

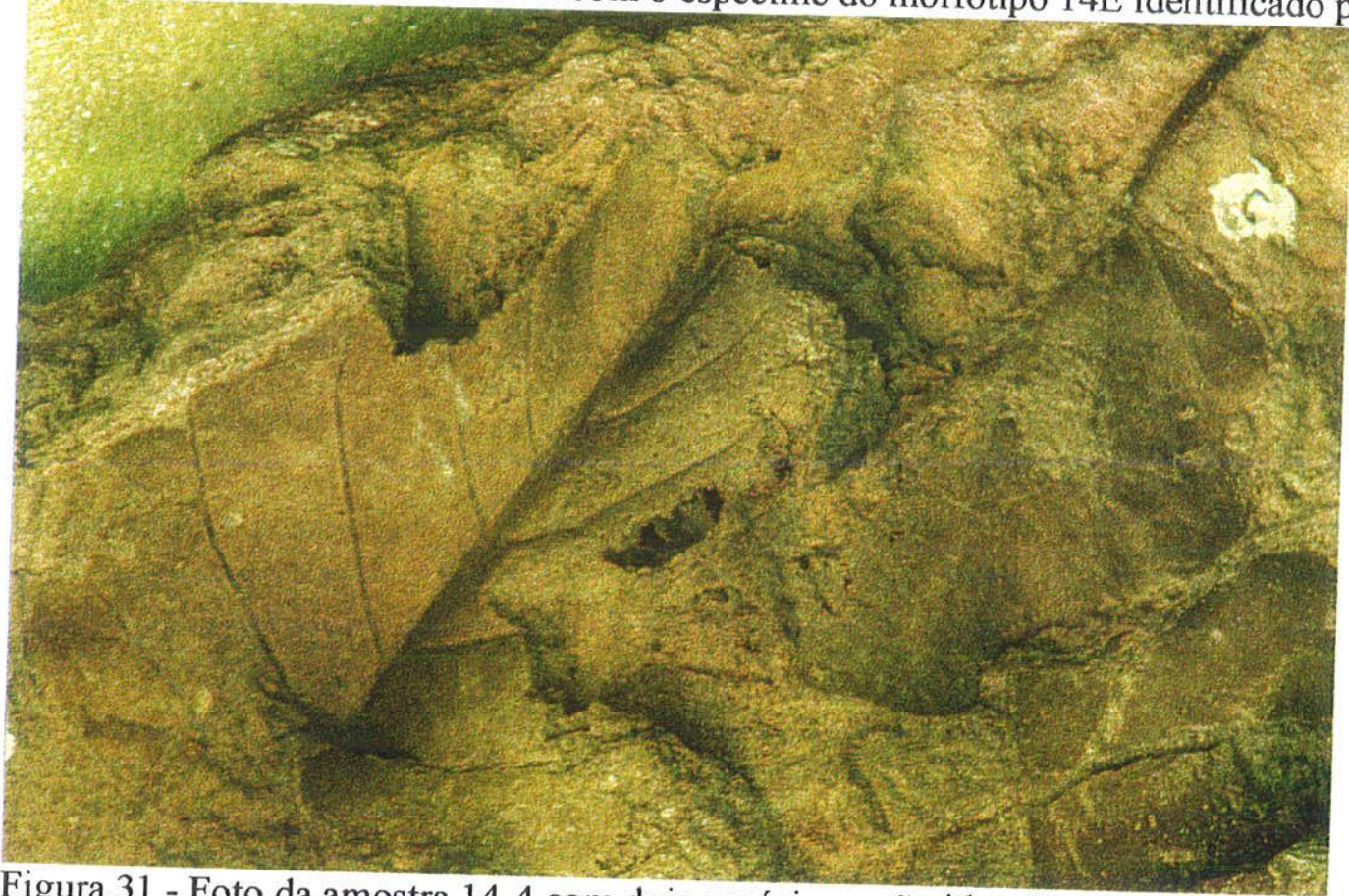

Figura 31 - Foto da amostra 14-4 com dois espécimes não identificados, sendo o da direita, reconhecido pela letra c, uma possível Bauhnia (Leguminosae). 
Morfotipo 15A
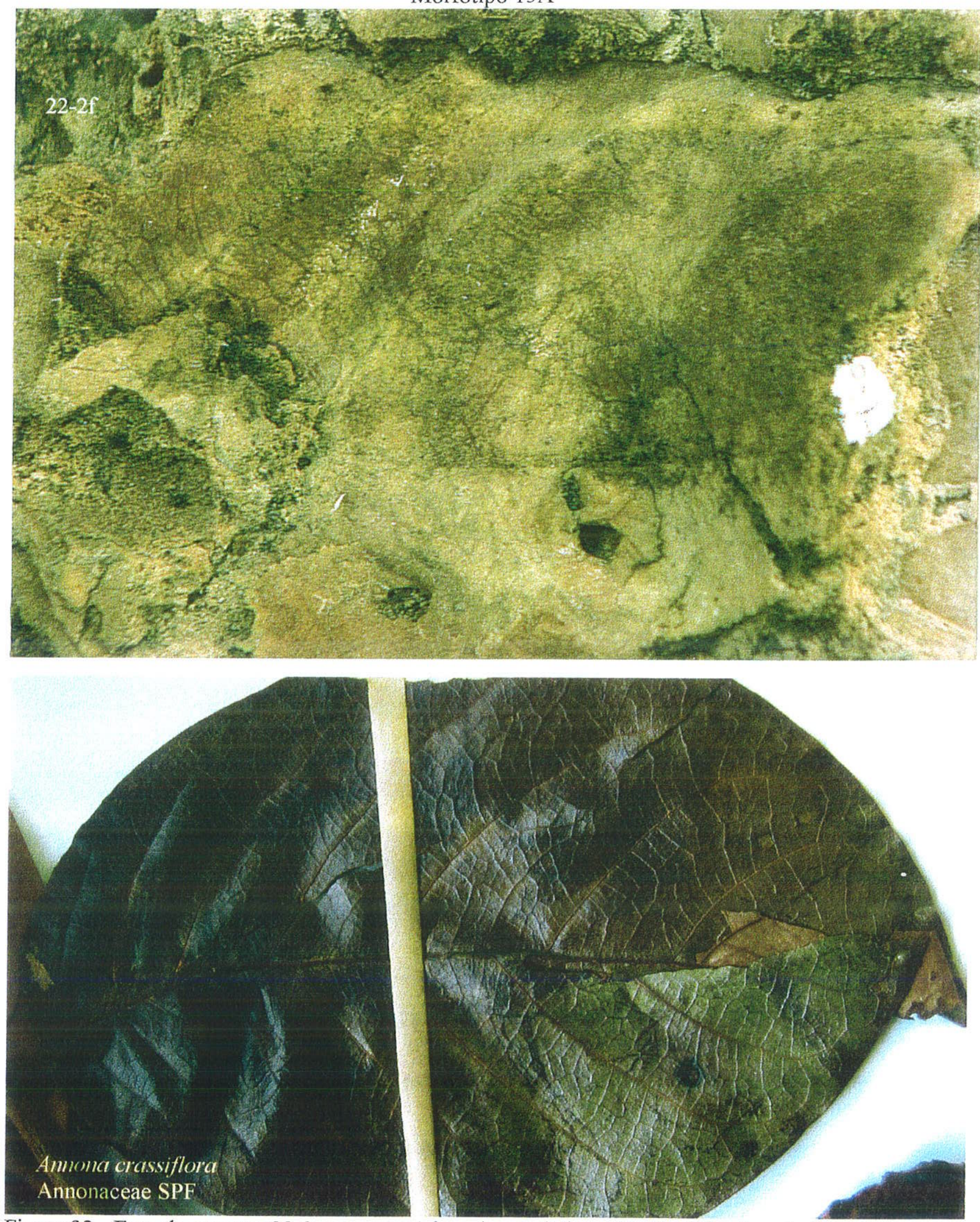

Figura 32 - Foto da amostra 22-2 com o espécime do morfotipo $15 \mathrm{~A}$ identificado pela foto abaixo. 


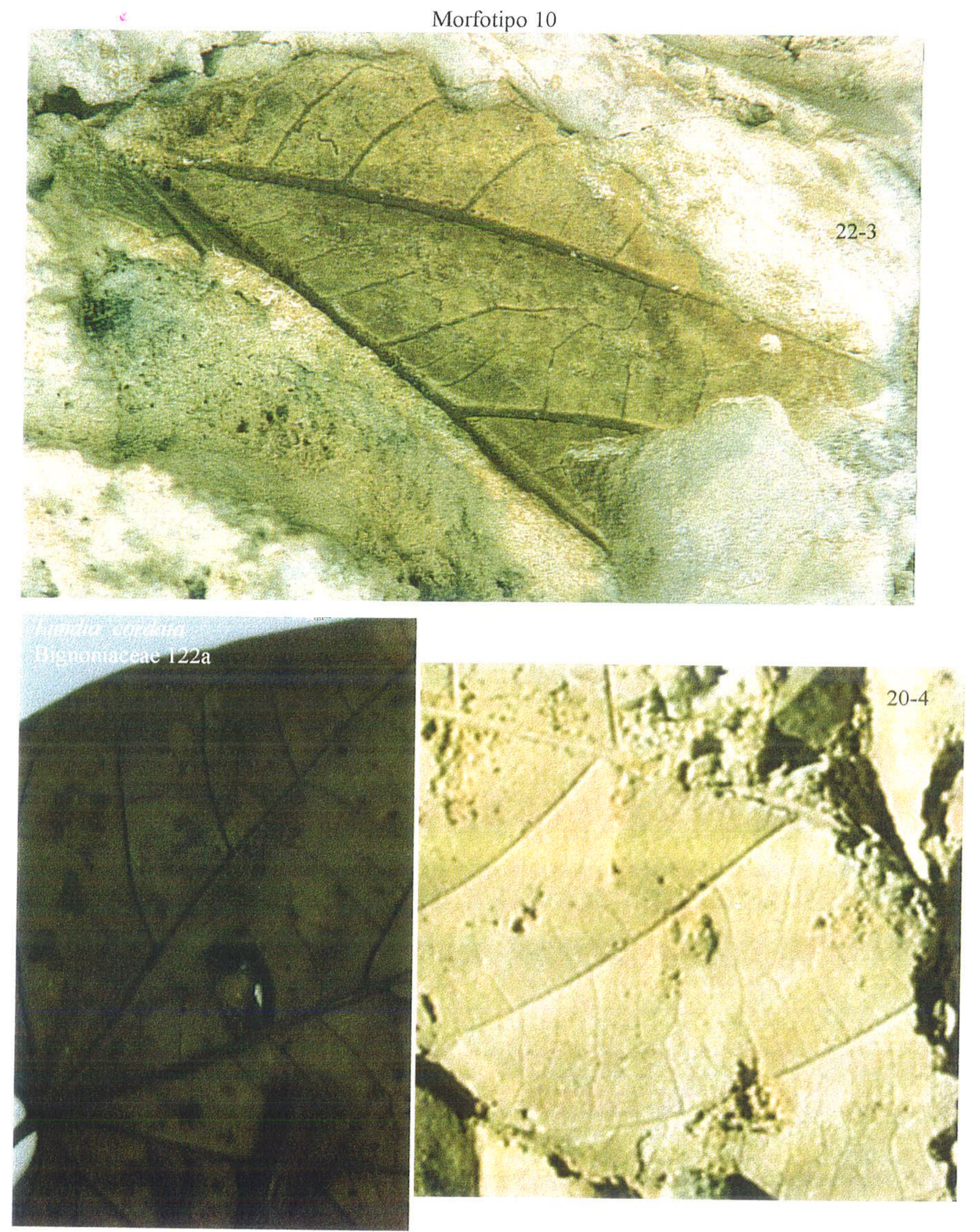

Figura 33 - Foto da amostra 22-3 com espécime do morfotipo 10 identificado pela foto abaixo do mesmo. Embaixo no canto direito: foto da amostra 20-4 representativo do morfotipo 15C, identificado como Sloanea guianensis (Elaeocarpaceae). 
6.2 - Composição floristica da assembléia fóssil de Campo Formoso, BA

Dos 69 morfotipos que puderam ser descritos, 20 näo puderam ser identificados, mas 49 morfotipos foram identificados, sendo um restrito à familia Sterculiaceae, quatro à gèneros: Abutilon sp. e Sida sp. (Malvaceae), Begonia sp. (Begoniaceae) e Helicreres sp. (Sterculiaceae) e 44 chegando a nivel de espécies, constituindo assembléia bastante diversificada. O porcentual de identificação também pode ser considerado alto, salientando a importância de se realizar estudos em herbários próximos a área em estudo, de forma a permitir identificações confiáveis.

Das 44 espécies identificadas, 2 apresentam grau de incerteza de alto a moderado, sendo que Davilla flexuosa (Dilleniaceae) chega a ser considerada apenas como comparação, dado o alto grau de incerteza, o que não acontece com Jacaranda irwinii (Bignoniaceae). Quatorze chegam a ter identificação com grau de incerteza moderado, algumas vezes em decorrência do grande número de espécies na familia, ou em muitos casos, devido ao tipo de preservação da folha fóssil: Alchoernea triplinervia e Aparisthmium cordatum (Euphorbiaceae, figura 29, página 110); Cordia trichoclada (Boraginaceae); Eriope hypenioides (Lamiaceae); Hirtella ciliata e licania litoralis (Chrysobalanaceae); Ilex psammophila (Aquifoliaceae); Luehea grandiflora (Tiliaceae); Piper tectoniffolia (Piperaceae); Prumus sellowi (Rosaceae, figura 26, página 107); Rawvolfia brasiliensis (Apocynaceae); Rollinia bahiensis e R. sylvatica (Annonaceae) e Vismia latifolia (Guttiferae = Clusiaceae).

Das 28 espécies restantes, 9 possuem graus de incerteza de moderados a baixos. Estes graus de incerteza reffetem a preservação dos espécimes fósseis, muitas vezes fragmentados. Estas nove espécies são: Banisteriopsis stellaris (Malpighiaceae); Chaetocarpus echinocarpus, Plukenetia tamnoides e Sebastiania brasiliensis (Euphorbiaceae, figura 28, página 109); Conchocarpus diadematus (Rutaceae); Connarus suberosus (Connaraceae); Eriope hypolenca (Lamiaceae); Herissantia tiubae (Malvaceae) e Tetrastylidium brasiliensis (Olacaceae).

Onze espécies exibem graus de incerteza baixos na identificação e quatro apresentam graus muito baixos, sendo que as três espécies de Annona possuem graus baixos devido ao estudo complementar realizado com as espécies de Annona presentes no herbário SPF (A. coriacea, $A$. crasifolia e A. glabra - Amnonaceae, figura 32, página 112). Já Centropogon cormutus (Campanulaceae) foi identificada apenas pelo ápice e apenas pela base em afloramentos diferentes. Cada fragmento de Centropogon cormutus havia sido considerado de morfotipos diferentes, mas estudos mostraram tratar-se de uma única espécie. A presença de uma mesma espécie através de fragmentos inicialmente considerados distintos reforça a presença da espécie. 
Entre as espécies com graus baixos de incerteza encontram-se: Banisteriopsis membranifolia (Malpighiaceae, figura 26, página 107); Begonica reniformis ou B. fischerii (Begoniacae, figura 25, página 106); Cecropia saxatilis (Cecropiaceae); Drymonia coccinea (Gesneriaceae); Gallesia scorododendron (Phytolacaceae); Hyptis lutescens e H. multiflora (Lamiaceae, figura 27, página 108); Lundia cordata (Bignoniaceae, figura 33, página 113); Maytemus cantingarum (Celastraceae); Sloanea guianensis (Elaeocarpaceae, figura 33) e Zizyphus joazeiro (Rhamnaceae, figura 30, página $111)$.

Teoricamente, estas últimas 15 espécies, com graus de incerteza baixos e muito baixos, fornecem evidências mais confiáveis da composiçăo floristica da assembléia fóssil. Nestes termos, a familia mais diversificada seria Annonaceae, com 3 espécies mais caracteristicas do bioma cerrado, seguida de Begoniaceae e Lamiaceae, com 2 espécies cada, mas que, muitas vezes, não aparecem em listas florísticas devido aos seus hábitos herbáceos. Outras nove famílias apresentam uma única espécie, entre elas Malpighiaceae, familia importante na flora da Caatinga.

Considerando-se o total da assembléia, tanto Annonaceae quanto Euphorbiaceae estão representadas por 5 espécies. Entretanto, a identificação com grau baixo de incerteza de espécies de Euphorbiaceae fora prejudicada pela grande diversidade da família, ausência de estudo comparativo no herbário SPF e fragmentação dos espécimes geralmente de grandes tamanhos, fazendo com que a família não conste da lista das 15 espécies mais confráveis. Do mesmo modo, Lamiaceae e Begoniaceae também estão entre as mais representadas na assembléia total, embora a primeira seja constituída de 4 espécies, igual número apresentado por Malvaceae enquanto que Begoniaceae possui 3 espécies. A familia Malvaceae, embora tenha sido estudada também através do herbário SPF, foi identificada em grau moderado principalmente pela grande similaridade que ocorre entre Malvaceae, Sterculiaceae e Tiliaceae, sendo que algumas vezes as folhas dessas três familias sejam parecidas também com Bombacaceae e Elaeocarpaceae. Elaeocarpaceae e Sterculiaceae exibem duas espécies cada, Tiliaceae apenas uma e Bombacaceae não se encontra entre as identificadas na assembléia fóssil.

Outras três famílias estão representadas na assembléia total com 2 espécies cada: Bignoniaceae, Chrysobalanaceae e Malpighiaceae. Excluindo-se as famílias que apresentam mais de uma espécie, 10 outras famílias estão representadas na assembléia fóssil de Campo Formoso, totalizando 16 famílias com uma espécie cada.

O total das espécies registradas na assembléia fóssil estão presentes nos mais diversificados ambientes, considerando-se a distribuição das espécies conforme documentação feita no ALCB, $15,1 \%$ das espécies se distribuem no cerrado e $15,1 \%$ em vegetação de campo rupestre, podendo totalizar $30,2 \%$ para o Bioma Cerrado. Vegetações ombrófilas densas somadas a outras 
consideradas como Mata Atlântica, corresponderiam a 13,7\% das espécies, além de mais 13,7\% descrita com mata ciliar. A vegetação de caatinga e de floresta estacional apresentariam cada $12,3 \%$, seguidas por mata de grotão $(5,5 \%)$, restinga $(4,1 \%)$, campos gerais $(2,7 \%)$ e até vegetação de praia, mata de cabruca (plantação de cacau com mata secundária), mata de altitude e mata de encosta, com 1,4\% cada uma. Entretanto, a distribuição das espécies pode ser muito maior que a documentada no estudo realizado no herbário.

Considerando-se que cada espécie pode sofrer variações na morfologia foliar de acordo com o clima e estrutura da vegetação, opta se por verificar a ocorrência do espécime que permitiu a identificação apenas das 15 espécies com grau baixo de incerteza, seis em florestas úmidas (40\%), três espécies ocorrem no cerrado (20\%), três ocorrem em florestas estacionais (20\%), duas ocorrem na caatinga $(13,3 \%)$ e apenas uma espécie ocorre no campo rupestre $(6,7 \%)$. Analisando-se a assembléia total, poder-se-ia sugerir a ocorrência de floresta úmida com forte influência do cerrado, mas ao verificar apenas as morfoespécies com baixo grau de incerteza, observa-se mistura vegetacional com espécies hoje presentes em ambientes úmidos, possivelmente de dossel fechado. É interessante constatar no próximo capítulo, que a análise físionômica da assembléia fóssil sugere interpretação semelhante.

Todas as famílias até então confirmadas no registro fóssil, são de distribuição tropical, algumas com distribuição também nas regiões subtropicais e outras poucas atingem a região temperada. A família Rhamnaceae se distribui, primariamente, na região temperada, mas Zizyphus joazeiro é típica da região de caatinga.

6.3 - Análise da distribuição das espécies registradas

As espécies registradas na assembléia fóssil de Campo formoso foram comparadas com algumas listas florísticas publicadas: nove listas florísticas de caatinga (Alcoforado-Filho et al, 2003; Araújo et al., 1995; 2002; Ferraz et al., 1998; Figueiredo et al., 2000; Nascimento et al., 2003; Pereira et al., 2002; Rodal et al., 1998; Trovão et al., 2004), nove listas de florestas estacionais (Carvalho et al., 1995; 2000; Lopes et al., 2002; Meira-Neto \& Martins, 2002; OliveiraFilho \& Machado, 1993; Oliveira-Filho et al., 1994; Rodrigues \& Araújo, 1997; Silva et al., 2004; Vilela et al., 1995) e nove listas floristicas de cerrado (Andrade $e$ t al., 2002; Barreira et al., 2002; Costa \& Araújo, 2001; Costa et al., 2004; Felfili et al., 2002; Imanã-Encinas et al., 1995; MeiraNeto \& Sapporetti Jr., 2002; Pedralli et al., 2000; Silva et al., 2002). 
Considerandomse todas as espécies identificadas, independente do grau de incerteza na identificação, as espécies registradas em áreas com vegetaçăo de cerrado representaria a maioria das espécies presentes, incluindo sete espécies: Ammona coriacea e A. crassiflora (Annonaceae, figura 32, página 112), Banisteriopsis stellaris (Malpighiaceae), Centopogon cormutus (Campanulaceae), Commarus suberosus (Connaraceae), Davilla elliptica (Dilleniaceae) e Hirtella ciliata (Chrysobalaceae). Os elementos presentes em tlorestas estacionais também estão representados por sete espécies, mas muitas são de ampla distribuição geográfica. Correspondem basicamente à família Euphorbiaceae, que normalmente possui grau de incerteza moderado na identificação devido a grande diversidade da familia. Estão registradas Alchoernea triplinervia, Aparisthmium cordatum, Chaetocarpus echinocarpus e Sebastiania brasiliensis (Euphorbiaceae, figura 29, página 110), além de Luehea grandiflora (Tiliaceae), Prumus sellowii (Rosaceae, figura 26, página 107) e Rollinia sylvatica (Annonaceae). Na caatinga pode-se observar três espécies e quatro gêneros, sendo Banisteriopsis membranifolia (Malpighiaceae, figura 26, página 107) e Hirtella ciliata (Chrysobalaceae) registradas em apenas um levantamento florístico, Zizyphus joazeiro (Rhamnaceae, figura 30, página 111) em cinco deles, muito embora seja considerada espécie típica de caatinga e os gêneros Cordia (Boraginaceae), Helicteres sp. (Sterculiaceae), Maytenus (Celastraceae) e Sida sp. (Malvaceae).

\subsection{1 - Análise das espécies presentes em cerrado}

Annona coriacea (Annonaceae) foi registrada em seis trabalhos fĭtossociológicos desde a Chapada do Araripe, CE até São Paulo, em altitude que varia de 590 a 740 m incluindo a Serra do Cipó, MG (Barreira et al., 2002; Costa et al., 2004; Felfili et al., 2002; Fidelis \& Godoy, 2003; Meira-Neto \& Saporetti Jr., 2002; Saporetti Jr. et al., 2003). A espécie distribui-se, no entanto, na Bahia, Goiás, Minas Gerais, São Paulo e Tocantins, segundo Mass et al. (2001), mas também no Ceará, Pernambuco e Mato Grosso segundo Fries (1931) apud Pontes et al. (2004). A espécie ocorre entre 80-1120 metros de altitude sendo muito comum nas vegetações savânicas. Normalmente constituí-se de arbusto ou árvore de 3 a 18 metros de altura, folhas coriáceas, elipticas, glabra nos dois lados, base sempre cordada e margem sempre ondulada (Mass et al., 2001). Uma única coleta desta espécie foi realizada na Paraíba no domínio da caatinga (Pontes et al., 2004).

Annona crassiflora (Annonaceae) foi registrada em seis estudos fitossociológicos realizados, do Maranhão a Minas Gerais, novamente incluindo a Serra do Cipó (Barreira et al., 2002; Costa \& Araújo, 2001; Imaña-Encinas et al., 1995; Meira-Neto \& Saporetti Jr., 2002; Saporetti Jr. el al., 2003; Silva et al., 2002). A ocorrência na Serra do Cipó é significativa neste estudo porque 
encontra-se a 850 metros de altitude com precipitação anual de 1.500 milimetros. A espécies distribui-se na Bahia, Distrito Federal, Goiás, Minas Gerais, São Paulo e Tocantins no cerrado ou cerradăo entre 400 e 1200 metros de altitude. Árvore pequena, de tronco sempre xeromorfo, folhas ovais a obovais, glabras (Maas et al., 2001). Estudos mostram que áreas proximas, com vegetações similares, podem apresentar a espécie numa área e não apresentar em outra. É possivel que as variações minerais ou até mesmo a drenagem do solo, influenciem na sua distribuição (Silva et al., 2002)

Banisteriopsis stellaris (Malpighiaceae) foi registrada no estudo fitossiológico realizado em Uberlândia, MG e na Chapada do Araripe, CE (Costa et al., 2004), muito embora tenha sido registrada em caatinga, segundo documentação do ALCB. Centropogon cornutus (Campanulaceae) foi registrado apenas em Uberlândia (Araújo et al., 2002).

Já a espécie Connarus suberosus (Connaraceae) foi documentada em sete análises florísticas desde o sudoeste de Goiás passando por Mato Grosso e Minas Gerais assim como um único espécime foi registrado na fazenda Água Branca, em Brasília, uma área de cerrado stricto senso (Andrade et al., 2002; Cardoso et al., 2002; Costa \& Araújo, 2001; Fiedler et al., 2004; Felfili et al., 2002; Saporetti Jr. et al., 2003; Silva et al., 2002).

Hirtella ciliata (Chrysobalaceae) foi registrada no cerrado de Santa Quitéria, MA (ImañaEncinas et al., 1995) e na Chapada do Araripe, CE (Costa et al., 2004).

A espécie Luehea grandiflora (Tiliaceae), comum em florestas estacionais, também foi registrada no cerradão da Reserva Particular do Patrimônio Nacional do Panga em Uberlândia, MG (Costa \& Araújo, 2001).

Das sete espécies da assembléia fóssil de Campo Formoso, documentadas em vegetação de cerrado, três apresentam grau de incerteza muito baixo, sendo que Annona coriacea e A. crassifolia, estão entre as melhores representações.

\subsection{2 - Análise das espécies presentes em caatinga}

Hirtella ciliata (Chrysobalaceae) foi registrada em levantamentos realizados na chapada de São José, no município de Búque, PE: Rodal et al. (1998) analisou área a 4 quilômetros da sede do município em $800 \mathrm{~m}$ de altitude, enquanto que Figueiredo et al. (2000) analisou área a 86 quilômetros da sede do município em $600 \mathrm{~m}$ de altitude. Rodal et al. (1998) afirmam que a vegetação da área destaca-se da caatinga, que a circunda, principalmente pelo seu aspecto perenifólio e pela ausência de elementos espinhosos, mas também por exibir fisionomia arbustiva distinta dos padrões encontrados nos levantamentos de carrasco ou caatinga. A espécie em questão é descrita como elemento que ocorre em cerrado de altitude. 
Zizyphus joazeiro (Rhamnaceae) foi registrado em cinco estudos floristicos em Pernambuco e Paraiba, tanto na margem de rio e em dique marginal, quanto em tabuleiros e locais de maior altitude como Caruaru, PE e entre os municípios de Areia e Remígio, PB a 596 metros de altitude (Alcotorado-Filho et al., 2003; Araujo et al., 1995; Ferraz et al., 1998; Nascimento et al., 2003; pereira et al., 2002). Ziziphus joazeiro é melhor registrado em áreas com ação antrópicas ou secundária (Pereira et al, 2003), pelo menos na Paraiba. Entre as espécies em comum entre a floresta serrana e a caatinga propriamente dita, registra-se Ziziphus jocazeiro (Rhamnaceae), embora o índice de similaridade seja inferior a 10\% (Rodal \& Nascimento, 2002). A espécie também é citada em áreas mais úmidas da caatinga nordestina (Rodal \& Nascimento, 2002).

O gênero Cordia (Boraginaceae) é significativo, embora a nível genérico, por atestar que certos gêneros podem penetrar, de forma variável, em diferentes biomas: seis das nove listas florísticas de caatinga e em sete das nove listas de florestas estacionais. A presença de tal gênero sugere a possibilidade de vegetação com mistura floristica de espécies dos dois biomas. Ressalta-se a ausência deste gênero nas listas florísticas de cerrado analisadas. O gênero Helicteres sp. (Sterculiaceae), por sua vez, é registrado em seis listas de caatinga e apenas em duas listas de floresta estacional.

A ocorrência do gênero Maytemus (Celastraceae) é interessante pela documentação na assembléia fóssil de Campo Formoso. Sugestiva de caatinga, pelo epíteto específico, não foi identificada nos levantamentos florísticos consultados. E o gênero Sida (Malvaceae) fò apenas documentado em quatro listas de vegetação de caatinga e em nenhuma outra, embora possa não constar destas listas em decorrência do seu hábito predominantemente arbustivo.

Também para o Bioma Caatinga, foram registrados sete gêneros e/ou espécies, como na vegetação de cerrado, só que apenas duas exibem graus moderados de incerteza na identificação, incluindo Hirtella ciliata, a espécie mais amplamente distribuida dentre as presentes na caatinga.

\subsection{3 - Análise das espécies presentes em florestas estacionais}

Alchoernea triplinervia (Euphorbiaceae) foi registrada em sete estudos florísticos todos em Minas Gerais, seja nas margens de rio ou em fragmento florestal em topografia acidentada (Carvalho et al., 1995a; 1995b; Lopes et al., 2002; Meira-Neto \& Martins, 2002; Oliveira-Filho \& Machado, 1993; Oliveira-Filho et al., 1994; Rodrigues et al., 2003; Silva et al., 2004), do mesmo modo que Aparisthmium cordatum (Euphorbiaceae) embora essa última espécie ocorra em apenas quatro listas florísticas (Lopes et al., 2002; Oliveira-Filho \& Machado, 1993; Silva et al., 2004; Vilela et al., 1995). (haetocarpus echinocarpus (Euphorbiaceae) foi registrada em Itambém do 
Mato Dentro, MG (Carvalho et al., 2000). E Sebastiania brasiliensis, também da familia Euphorbiaceae, às margens do Rio Grande, em Itutinga, MG (Vileta et al., 1995).

Luehea grandiflora (Tiliaceae) foi registrada em nove listas florísticas, todas em Minas Gerais. Ocorre desde mata de galeria periodicamente alagada quanto em região de serras, mesmo em topografia acidentada (Carvalho et al., 2000; Lopes et al., 2002; Meira-Neto \& Martins, 2002; Meira-Neto et al., 2003; Oliveira-Filho \& Machado, 1993; Oliveira-Filho et al, 1994; Rodrigues et al., 2003; Silva et al., 2004; Vilela et al., 1995).

Prunus sellowii (Rosaceae) encontra-se presente em quatro listas florísticas mineiras preferencialmente em lugares de maior altitude (Meira-Neto \& Martins, 2002; Oliveira-Filho et al., 1994; Rodrigues et al., 2003; Vilela et al., 1995).

Rollinia sylvatica (Annonaceae) foi registrada em sete trabalhos florísticos em Minas Gerais tanto nas margens do Rio Grande quanto na Serra de São José, Tiradentes (Carvalho et al., 1995a; 1995b; Lopes et al., 2002; Meira-Neto \& Martins, 2002; Oliveira-Filho \& Machado, 1993; Rodrigues et al., 2003; Silva el al., 2004; Vilela et al., 1995).

Considerando-se apenas as espécies presentes na floresta estacional, novamente registrariam-se sete espécies, como no cerrado e na caatinga, mas a grande diferença é que cinco delas (Alchornea triplinervia, Aparisthmium cordatum, Luehea grandiflora, Prumus sellowii e Rollinia sylvatica), justamente as de ampla distribuição geográfica, possui graus moderados de incerteza na identificação e as outras duas (Chaetocarpus echinocarpus e Sebastiania brasiliensis), de baixo a moderados. Visto deste modo, constataria-se que a influência da floresta estacional na assembléia fóssil de Campo Formoso seria pequena. Por outro lado, dez espécies presentes em Campo Formoso apresentam gêneros representados na floresta estacional, sendo quatro com grau de incerteza de baixo a muito baixo (Cecropia, Cecropiaceae, em seis listas; Helicteres, Sterculiaceae, em apenas duas; Maytenus, Celastraceae em cinco listas; Sloanea, Elaeocarpaceae, em seis), quatro com grau de incerteza moderado (Cordia, Boraginaceae presente em sete listas; Hirtella, Chrysobalanaceae em quatro listas; Piper, Piperaceae em cinco; Vismia, Guttiferae em cinco listas) e os outros dois com grau de incerteza moderado a baixo (Hyptis, Lamiaceae) e moderado a alto (Jacaranda, Bignoniaceae). Desse modo, não ficaria descartada a possibilidade de "descida" de alguns elementos destas florestas para a região de Campo Formoso. É interessante comentar que os gêneros Hyptis e Vismia também foram registrados em lista florística de cerrado (Costa et al., 2004). 
6.3.4 - Análise das espécies presentes em outros tipos vegetacionais

Annona glabra distribui-se na Bahia, Espírito Santo, Minas Gerais, Rio de Janeiro, São Paulo, ocorrendo ao nivel do mar em vegetações margeando mangues. Corresponde a arvore de 2 a 15 metros de altura com folhas subcoriáceas, elípticas e glabras (Maas et al., 2001). Entretanto, não foi registrada em nenhuma das listas floristicas consultadas.

Cecropia saxatilis (Cecropiaceae) foi registrada apenas nas florestas secas sobre afloramentos de calcário. Estas florestas secas apesar de possuirem espécies em comum com outras áreas, apresentam composição floristica peculiar e fisionomias bem diferenciadas, provavelmente devido ao tipo de solo (Silva \& Scariot, 2003).

Sloanea guianensis foi registrada na floresta de planície em Ubatuba, SP, localiza-se na planicie litorânea, distante cerca de 2,5 quilômetros da praia, na base de uma encosta. $\mathrm{O}$ dossel é alto, permitindo tênue distinção em dois estratos. Ocorre entre as cinco espécies mais importante no primeiro estrato (entre 15 e 25 metros) (Bencke \& Morellato, 2002).

\section{4 - Comparações florísticas}

Conforme comentado anteriormente, considerando-se as quinze espécies que fornecem evidências mais confiáveis da composição florística da assembléia fóssil, a familia mais diversificada seria Annonaceae, seguida de Begoniaceae e Lamiaceae (hábitos herbáceos). Outras nove famílias são representadas por uma única espécie, entre elas Malpighiaceae, familia importante na flora da caatinga.

Considerando-se todas as espécies identificadas, independente do grau de confiabilidade, as famílias mais diversificada seriam Annonaceae e Euphorbiaceae, seguidas de Malvaceae e Lamiaceae, Begoniaceae seguidas por Bignoniaceae, Chrysobalanaceae, Elaeocarpaceae, Malpighiaceae e Sterculiaceae com duas espécies cada. Além de 16 familias com uma espécie cada. A lista completa das espécies identificadas pode ser consultada na tabela 6 (páginas 94-96).

Além de listas florísticas publicadas, conforme comentado anteriormente, alguns trabalhos fitossociológicos discutem a abundância e a riqueza das principais famílias presentes numa associação, aumentando o número de trabalhos que podem ser usados nas comparações com a assembléia fóssil de Campo Formoso.

A primeira hipótese a ser testada refere-se a "descida" de espécies da floresta estacional para a região de Campo Formoso, conseqüência da menor sazonalidade das chuvas, isto é, chuvas distribuídas por mais meses, e pequena diminuição da temperatura. Muito embora um porcentual pequeno de espécies presentes em florestas estacionais tenha permitido a identificação dos 
espécimes fósseis da assembléia de Campo Formoso, o número de espécies que se distribuem na floresta estacional é similar aos de outros biomas. Mesmo sendo espécies de ampla distribuição geográfica, as espécies presentes nas florestas estacionais não ocorrem preferencialmente em região de caatinga. O grau moderado de incerteza na identificação é decorrente da fragmentação dos espécimes fósseis e da diversidade da familia Euphorbiaceae.

Comparando-se então a diversidade nas florestas estacionais de acordo com doze áreas observa-se que as familias mais diversificadas nem sempre são as mesmas em cada local. A familia Euphorbiaceae é a única sempre presente entre as mais diversificadas, seguida pelas leguminosas, ausentes apenas na floresta estacional em afloramento calcário en GO (Silva \& Scariot, 2003). Myrtaceae e Rubiaceae estão entre as mais diversificadas em dez associações estudadas, Annonaceae em oito associações, Lauraceae em sete, Flacourtiaceae em seis e Melastomaceae em cinco associações estudadas. Outras quatorze famílias estão entre as mais diversificadas, apenas em uma ou duas associações estudadas, como Bignoniaceae.

A importância de Myrtaceae foi registrada na floresta serrana de Triunfo, Estado de Pernambuco, e em florestas da costa atlântica brasileira (Peixoto \& Gentry, 1990), sendo considerada como bastante comum no domínio atlântico (Rodal \& Nascimento, 2002). Fato curioso é Myrtaceae não ter sido registrada na assembléia fóssil de Campo Formoso. Pode-se considerar a hipótese de não reconhecimento da família entre os espécimes fósseis, para o caso de espécies que não apresentam a nervação típica da família ou o espécime não ter sido amostrado, situação pouco provável já que foram analisados mais de 800 espécimes fósseis, que mesmo fragmentados, não apresentam a nervação típica da família. Poder-se-ia sugerir a pequena relevância das espécies mais tipicamente atlânticas na assembléia fóssil.

Na Serra da Capivara, PI, a família Bignoniaceae teve maior expressão na transição caatinga-de-areia e carrasco, não sendo registrada na caatinga. Já Euphorbiaceae é bem representada em áreas sedimentares e em áreas cristalinas, embora praticamente não ocorra sobreposição de espécies (Lemos \& Rodal, 2002).

Em termos florísticos, as florestas estacionais presentes na Bahia aparentam maior afinidade com as florestas estacionais de Goiás, com $21,8 \%$ de similaridade, posteriormente com Minas Gerais, com similaridade entre 8,8 e 13,7\% e São Paulo, com similaridade entre 5,8 e 8,6\%. Estes indices podem ser utilizados apenas comparativamente, já que o levantamento realizado no ALCB foi parcial. Se determinada espécie ocorre em mais de um tipo vegetacional, ela pode ter sido documentada em apenas um destes tipos. Desse modo, os padrões de similaridade não são bem representativos, assim como a menor diversidade apresentada. 
Entretanto, algumas informações são interessantes. Mesmo considerando-se que a lista gerada corresponde a diversidade minima, é possivel notar a maior diversidade especifica de algumas familias ou mesmo a sua presença. Esta diversidade é bem observada em Euphorbiaceae, Bignoniaceae, Rutaceae e Sapindaceae, e, em menor proporção, em Anacardiaceae, Apocynaceae, Malpighiaceae e Flacourtiaceae. Algumas familias apresentam-se mais diversificadas por ter sido incluidas espécies herbáceas ou trepadeiras, nem sempre presentes nas listas floristicas, como Chrysobalanaceae, Convolvulaceae e Polygalaceae, mas também Passiforaceae, Malvaceae, Sterculiaceae, Ulmaceae e Verbenaceae. As principais exceções ocorrem em Minas Gerais, que apresentam maior diversidade de Annonaceae, Anacardiaceae e Flacourtiaceae. Esses dados reforçam a importância da família Euphorbiaceae nas florestas estacionais da Bahia, assim como Bignoniaceae e Malpighiaceae, embora elas só tenham duas espécies por família identificadas na assembléia fóssil. Rutaceae e Apocynaceae só possuem uma espécie na assembléia. Sapindaceae, Anacardiaceae e Flacourtiaceae, por sua vez, não possuem espécies que tenham sido identificadas.

Analisando-se tais dados, pode-se sugerir que as espécies de ampla distribuição geográficas, associadas com algumas outras, foram capazes de migrar para a depressão sertaneja em algum momento do último evento glacial. Que espécies da Caatinga resistiram a essas mudanças climáticas?

Comparando-se a diversidade da assembléia fóssil com a diversidade da vegetação de caatinga, de acordo com dez trabalhos, observa-se que as famílias mais diversificadas são mais variadas em relação a floresta estacional, mas também apresenta Euphorbiaceae presente em todas as associações estudadas, seguida das Leguminosas, ausentes apenas na Serra da Capivara, PI (Lemos \& Rodal, 2002) e no cariri paraibano (Trovão et al., 2004). Myrtaceae, Bignoniaceae e Anacardiaceae estão entre as mais diversificadas apenas em quatro associações estudadas, enquanto Apocynaceae e Cactaceae estão presentes em três associações. Outras dezessete famílias estão entre as mais diversificadas apenas em uma ou duas associações estudadas, incluindo Malpighiaceae e Malvaceae.

Aparentemente, poucas espécies da Caatinga puderam ser identificadas na assembléia fóssil, muito embora possam estar representadas nos morfotipos 5 (página 70), que representam pelo menos sete espécies. A identificação de espécimes pequenos é sempre mais difícil devido à dificuldade de se analisar todos os seus padrões de nervação.

Em termos florísticos, a caatinga mostra fortes ligações com a floresta estacional. Estas ocorrem em disjunções, principalmente nas áreas transicionais entre a mata atlântica e a caatinga, a leste, entre a caatinga e o cerrado, a oeste ou entre a caatinga e os campos de altitudes (cerrados e campos rupestres) na porção central do Estado. Nas regiões montanas, a altitudes entre 700 e 2000 
metros, a caatinga é substituída pelos cerrados e campos rupestres, verdadeiros refúgios ecológicos em meio ao semi-árido, predominantes nos maciços montanhosos da Chapada Diamantina (Melo, 1999). Esta ligação floristica com as florestas estacionais pode vir a mascarar a presença de algumas espécies de caatinga quando se tenta avaliar quais espécies da floresta estacional teriam "descido".

Considerando-se que a altitude na regiäo em estudo, varia de 400 a 800 metros e a precipitação varia de 300 a 500 milimetros por ano e que as chapadas presentes no entorno possuem altitude de 800 a 1.200 metros, com precipitação entre 800 e 1.100 milimetros por ano (SEI, 2005), a variação climática ocorrida no último máximo glacial corresponderia às condições climáticas atualmente presentes em altitudes de 900 metros e precipitação de no mínimo de 800 milimetros por ano. Este dado pode ser confirmado pela presença de Annona crassifolia, presente na Serra do Cipó, MG a 850 metros de altitude com precipitação anual de 1.500 milímetros (Meira-Neto \& Saporetti Jr., 2002), muito embora a precipitação média do parque corresponda a 700 milímetros de chuva por ano (Fundação Rio Cipó, 2006).

Outra hipótese que precisa ser avaliada corresponde à migração de espécies de cerrado vindo principalmente de oeste. A princípio a hipótese parece improvável em vista da distância entre estes biomas. Ao se considerar o tipo de mudança climática que teria ocorrido na região, parece bastante provável que algumas espécies de cerrado teriam acompanhado a ocorrência de sazonalidade mais típica do cerrado, enquanto a própria região do planalto central carecia de chuvas regularemente sazonais e apresentava-se também mais frio, conforme indica dados palinológicos (Ledru, 1993; Salgado-Labouriau et $a l$., 1998). Tal situação poderia explicar a ocorrência de sete espécies de cerrado e outros dez gêneros que também ocorrem em florestas estacionais. Seriam espécies aptas à migração.

Em comparação com a diversidade da vegetação de cerrado, de acordo com dez trabalhos, as famílias mais diversificadas são em menor número, no cerrado, em relação às florestas estacionais e à vegetação de caatinga. Não ocorre uma única familia que esteja presente em todas as associações. A família Leguminosae está ausente entre as mais diversificadas apenas em Ouro Preto, MG, que exibe associação florística com maior diversidade de Asteraceae e Melastomataceae (Pedralli et al., 2000). A família Asteraceae é predominantemente herbácea e a família Melastomataceae é comum em vegetações secundárias, o que pode ter afetado a diversidade das Leguminosae. Outra família bem diversificada que parece ser bem comum no cerrado é Vochysiaceae, presente em sete das associações. Myrtaceae está entre as mais diversificadas em cinco associações e Malpighiaceae e Asteraceae em apenas quatro associações estudadas. Outras onze familias, como Rubiaceae, Euphorbiaceae e Annonaceae, constam entre as mais diversificadas ou em uma ou duas associações estudadas. 
No Nordeste do Brasil, as disjunções de cerrado ocorrem principalmente em baixas altitudes, de 0 a 500 metros, nos tabuleiros costeiros (Formaçăo Barreiras), nos Estados de Pernambuco, Paraiba e Ceará. O cerrado da Chapada do Araripe é uma disjunção situada a altitude de 800 a 900 metros, encravado no domínio semi-árido da caatinga, tendo em vista a altitude e, conseqüentemente, sob maior precipitação e menor temperatura que na caatinga do entorno (Costa et al., 2004). Estas disjunções parecem indicar a possibilidade do cerrado migrar, caso as condições sejam apropriadas. Seria o caso da última fase glacial para a região de Campo Formoso.

Prado \& Gibbs (1993) observam que poucos estudos têm sido realizados buscando compreender a influência das mudanças climáticas do Pleistoceno na expansão da vegetação decídua e semidecídua na América do Sul e que muitas espécies lenhosas, que estariam envolvidas nos processos de migrações cíclicas do Pleistoceno, são membros de comunidades florestais deciduais tropicais e subtropicais, tais como a caatinga e algumas matas semidecíduas de São Paulo e Paraná, entre outras.

Além da influência das formações vegetais adjacentes, a composiçăo florística, de forma geral, pode ser influenciada por vários fatores em diferentes escalas. O clima, por exemplo, é considerado um dos principais fatores, atuando na composição florística em níveis regionais (Ledru 1993). Em escalas locais, a altitude, profundidade e composição química do solo, topografia, microambientes, entre outros, têm sido apontados como importantes na seleção das espécies. A ocorrência de espécies em habitats com condições ambientais variadas pode ser conseqüência não só de sua ampla tolerância, como também da presença de microambientes, como, por exemplo, clareiras ou sítios mais ou menos úmidos, que permitem o estabelecimento dessas espécies. Algumas espécies, apesar de terem ampla distribuição, exigem condições restritas de habitat (Rodrigues et al., 2003), o que justificam as premissas acima. 
7- Análise fisionomica dos diferentes tipos de vegetação da Bahia

7.1 - Análise global

A análise fisionòmica baseou-se no acervo do herbário ALCB. Todo o acervo, com exceção das monocotiledoneas, leguminosas, asteráceas e melastomatáceas, foi observado, mas não totalmente fotografado. Utilizando o princípio, estatisticamente válido, de escolhas aleatórias, todas as espécies foram documentadas. As quantidades de espécimes documentadas para cada espécie variaram de acordo com suas abundâncias e diversidades: espécies muito abundantes chegaram a ter mais de 10 exemplares documentados e, quando a espécie apresentava variação em sua fisionomia foliar, todas essas variações foram documentadas, principalmente se ocorressem dentro de um mesmo tipo vegetacional. A presença de espécies em tipos vegetacionais diferentes também foi registrada e documentada quando possivel, evitando escolhas não ateatórias. Desse modo a documentação é representativa da vegetação da Bahia como um todo, embora nem todas as espécies presentes num determinado tipo vegetacional tenham sido documentadas.

Após a completa análise de todos os dados obtidos no herbário, tentou-se estabelecer os padrões vegetacionais a partir da fisionomia foliar. Em princípio foram estabelecidas 144 "localidades" a serem comparadas com a assembléia de Campo Formoso. O termo "localidade" não se refere propriamente a uma cidade ou município, pois em alguns casos, um único município exibe diferentes tipos vegetacionais, e assim, cada tipo vegetacional foi considerado uma localidade. Estes casos são interessantes porque permitem verificar diferentes vegetações sujeitas a climas bem similares. Para melhor testar a hipótese de clima similar, foi estabelecida a "localidade total", na qual todas as suas vegetações encontram-se reunidas. A fim de facilitar a leitura dos gráficos, a figura 34 ilustra os municípios abrangidos neste estudo. A PCA das 145 "localidades" mostra resultado muito poluído e de difícil leitura do gráfico gerado. A assembléia de Campo Formoso foi posicionada entre as vegetações atuais da Bahia.

Procurando melhorar as interpretações, análises adicionais foram realizadas até se chegar a resultados mais satisfatórios, visando garantir a reprodutibilidade da análise. Esta análise foi realizada tendo em vista que a caatinga não segue os padrões fisionômicos estabelecidos por Wolfe (1993). Ao se excluir "localidades" de vegetação não indicada na etiqueta do herbário e as "localidades" que apresentavam menos de 20 espécies, não foi observada variação significativa no posicionamento das "localidades", o que demonstra confiabilidade na análise de uma forma geral, mesmo com "localidades" com pequeno número de espécies. Exceção apenas para quatro destas "localidades" com poucas espécies que estavam em pontos extremos no primeiro gráfico. 
Municíplos Estudadi

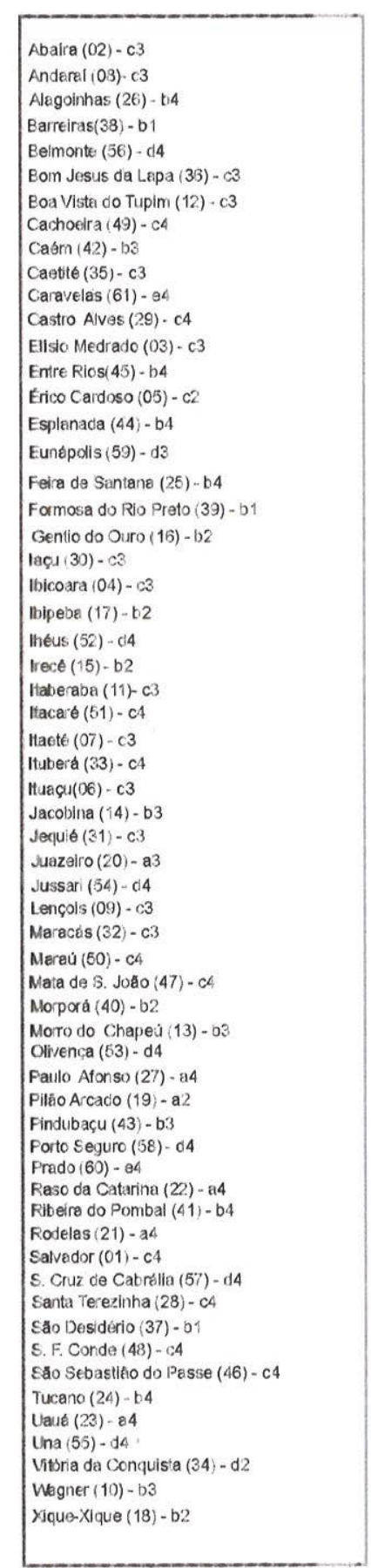

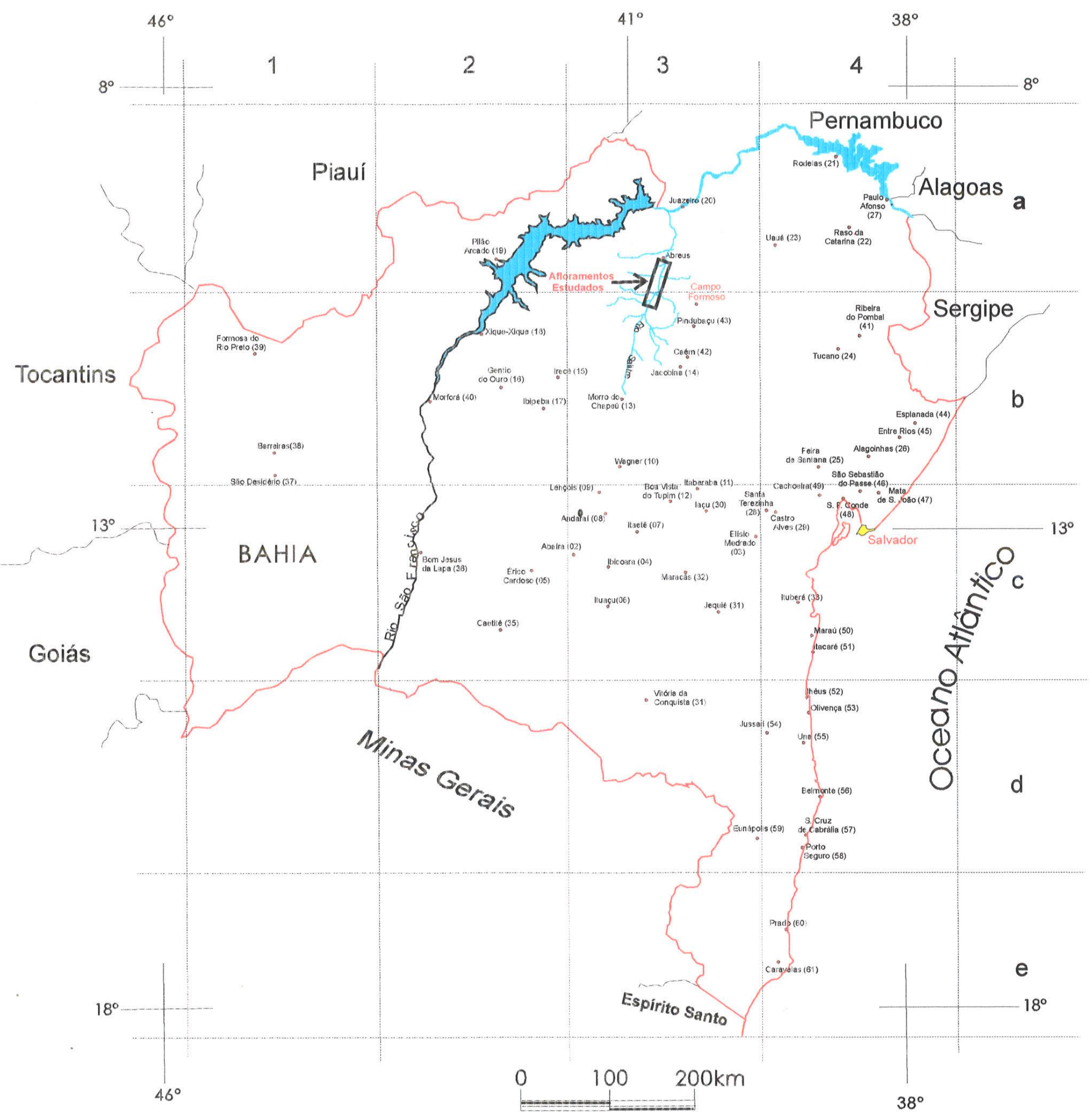

Figura 36 - Mapa do estado da Bahia indicando os municípios estudados na análise fisionômica. 


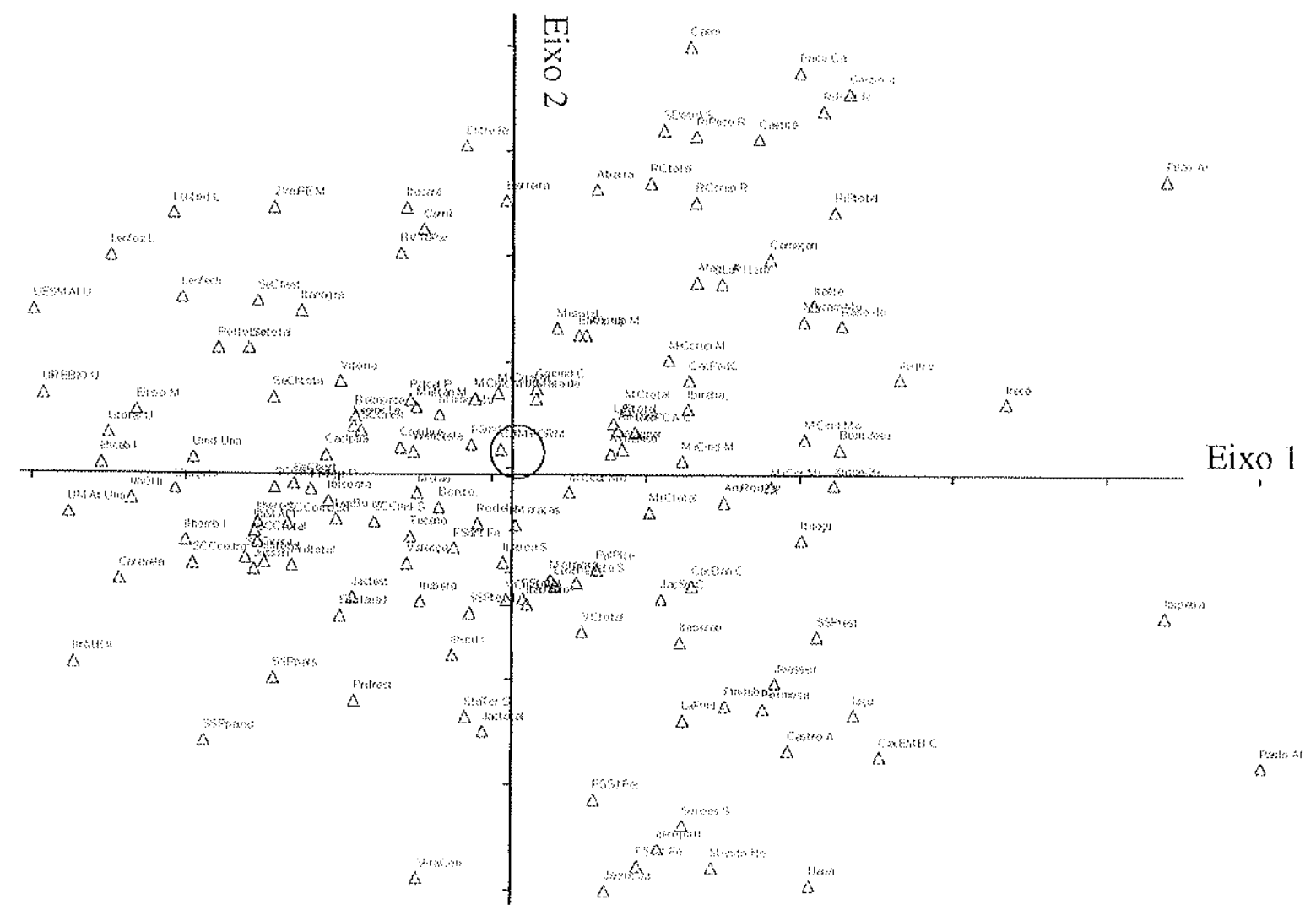

Gráfico 1 - Análise global: PCA de 144 "localidades" para comparação com a assembléia fóssil de Campo Formoso. Eixos 1 e 2. Abreviações utilizadas estão listadas na tabela 10

Nesta análise, representada no gráfico 1, a extremidade negativa do eixo 1 é baseada na ausência de dentes nas margens foliares, pelas maiores classes de tamanho, presença de ápice atenuado, base arredondada ou aguda (isto é, exceto base cordada), por formas foliares obovais ou elipticas com relação de delgadeza entre 2-4/1. Esses parâmetros, embora não correspondam exatamente aos padrões internacionais estabelecidos por Wolfe (1993), eles demonstram aumento de umidade, o que é corroborado pelas "localidades" de Mata Atlântica. A vegetação de Mata Atlântica, ou melhor dizendo, do Complexo vegetacional Atlântico, é denominada regionalmente de Mata higrófila sul-baiana e inclui "localidades" de floresta ombrófila densa e restinga. Algumas "localidades" de floresta estacional também apresentam características semelhantes, estando próximas as anteriormente citadas. É interessante comentar que a ocorrência de ápice emarginado sugere existência de problemas durante o desenvolvimento da folha, o que poderia indicar condições adversas ou vegetações ocorrendo no limite de seu habitat preferencial.

O eixo 2 não apresenta parâmetros de interpretações claras segundo os padtões vegetacionais, mas reúne em uma de suas extremidades, folhas lobadas e com dentes nas margens foliares, característica comumente apresentada por espécies de Euphorbiaceae. Além desses dois 
paràmetros, a extremidade do eixo 2 difere do eixo um por englobar também base cordada e arredondada. A "localidade" mais distante nesta extremidade do eixo dois corresponde à vegetaçăo de mata ciliar do município de Jacobina. Outras "Iocalidades" nesta extremidade incluem Simoes Filho, na região metropolitana de Salvador; Formosa do Rio Preto, município que faz fronteira com os estados de Tocantins e Piauí e exibe vegetação de cerrado; laçu e Joazeiro, com vegetação de caatinga; a estação da EMBASA em Cachoeiras, que contudo pode ter vegetação com influência antrópica; Itaberaba, Pindubaçu, que apresentam vegetação de floresta estacional; e São Sebastião do Passe com vegetação de restinga.

Algumas análises de PCA não serão demonstradas por inadequação de espaço e grau de interpretação necessário para o entendimento do estabelecimento do padrão fisionômico.

Cada vegetação foi analisada separadamente incluindo-se as regiões de contato. Em tese, as regiões de contato apresentam-se mais distantes das regiões da vegetação propriamente dita. Essas variações podem estabelecer o padrão fisionômico de cada vegetação. Para interpretar a assembléia fóssil de Campo Formoso, esta assembléia está presente em todas as análises realizadas.

\begin{tabular}{|c|c|c|c|c|c|c|c|c|c|c|c|}
\hline \multicolumn{2}{|c|}{$\begin{array}{l}\text { Legendas das cidades nos gráficos de } \\
\text { PCA }\end{array}$} & 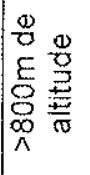 & 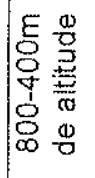 & 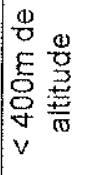 & 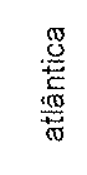 & 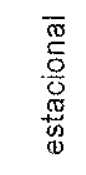 & 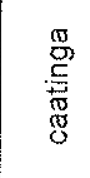 & 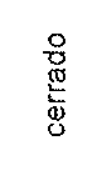 & 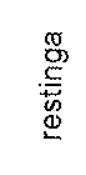 & 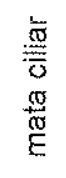 & 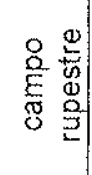 \\
\hline Abaíra & Abaíra & 5 & 5 & 0 & 0 & 0 & 3 & 3 & 0 & 3 & 0 \\
\hline Alag & Alagoinhas & 0 & 0 & 10 & 0 & 10 & 0 & 0 & 0 & & 0 \\
\hline AmRodPar & Amelia Rodrigues & 0 & 10 & 0 & 0 & 0 & 0 & 0 & 0 & 0 & -10 \\
\hline Andaraí & Andarai & 10 & 0 & 0 & 0 & 5 & 0 & 0 & 0 & 0 & 5 \\
\hline Barreira & Barreiras & 5 & 5 & 0 & 0 & 0 & 0 & 10 & 0 & 0 & 0 \\
\hline Belmonte & Belmonte & 0 & 0 & 10 & 10 & 0 & 0 & 0 & 0 & 0 & 0 \\
\hline BVTu Par & Boa Vista do Tupim & 0 & 10 & 0 & 0 & 10 & 0 & 0 & 0 & 0 & 0 \\
\hline Bom Jesu & Bom Jesuss da Lapa & 0 & 10 & 0 & 0 & 5 & 5 & 0 & 0 & 0 & 0 \\
\hline Bonito & Bonito & 0 & 0 & 10 & 0 & 10 & 0 & 0 & 0 & 0 & 0 \\
\hline $\mathrm{Cac}$ & Cachoeira & 0 & 0 & 10 & 5 & 5 & 0 & 0 & 0 & 0 & 0 \\
\hline CacBan & Cachoeira, Bananeiras & 0 & 0 & 10 & 10 & 0 & 0 & 0 & 0 & 0 & 0 \\
\hline CacEMB & Cac, Estaçäo EMBASA & 0 & 0 & 10 & 10 & 0 & 0 & 0 & 0 & 0 & 0 \\
\hline Caclpua & Cachoeira, Ipuacu & 0 & 0 & 10 & 0 & 10 & 0 & 0 & 0 & 0 & 0 \\
\hline CacMB & Cachoeira, Morro Belo & 0 & 0 & 10 & 0 & 10 & 0 & 0 & 0 & 0 & 0 \\
\hline CacPedC & Cac, Pedra do Cavalo & 0 & 0 & 10 & 0 & 10 & 0 & 0 & 0 & 0 & 0 \\
\hline CacPCA & Cac, Porto Castro Alves & 0 & 0 & 10 & 10 & 0 & 0 & 0 & 0 & 0 & 0 \\
\hline Caem & Caem & 0 & 0 & 10 & 0 & 5 & 5 & 0 & 0 & 0 & 0 \\
\hline Caetité & Caetité & 0 & 10 & 0 & 0 & 0 & 5 & 5 & 0 & 0 & 0 \\
\hline Cairú & Cairu & 0 & 0 & 10 & 0 & 0 & 0 & 0 & 10 & 0 & 0 \\
\hline Camaçari & Camaçari & 0 & 0 & 10 & 0 & 0 & 0 & 0 & 10 & 0 & 0 \\
\hline Caravela & Caravelas & 0 & 0 & 10 & 10 & 0 & 0 & 0 & 0 & 0 & 0 \\
\hline Castro A & Castro Alves & 0 & 10 & 0 & 0 & 5 & 5 & 0 & 0 & 0 & 0 \\
\hline Con & Conde & 0 & 0 & 10 & 0 & 3 & 0 & 3 & 0 & 3 & 0 \\
\hline Conind & Conde indeterminado & 0 & 0 & 10 & & & & & & & \\
\hline Conde e & Conde e vegetaçoses & 0 & 0 & 10 & 0 & 3 & 0 & 3 & 0 & 3 & 0 \\
\hline Elisio M & Elísio Medrado & 5 & 5 & 0 & 0 & 10 & 0 & 0 & 0 & 0 & 0 \\
\hline Entre Ri & Entre Rios & 0 & 0 & 10 & 10 & 0 & 0 & 0 & 0 & 0 & 0 \\
\hline Erico $\mathrm{Ca}$ & Erico Cardoso & 5 & 5 & 0 & 0 & 0 & 0 & 10 & 0 & 0 & 0 \\
\hline Esplanad & Esplanada & 0 & 0 & 10 & 5 & 5 & 0 & 0 & 0 & 0 & 0 \\
\hline Eunápoli & Eunápolis & 0 & 0 & 10 & 10 & 0 & 0 & 0 & 0 & 0 & 0 \\
\hline $\mathrm{FS}$ & Feira de Santana & 0 & 0 & 10 & 0 & 5 & 5 & 0 & 0 & 0 & 0 \\
\hline FSind & FS indeterminado & 0 & 0 & 10 & & & & & & & \\
\hline
\end{tabular}

Tabela 10 - Abreviações das "localidades" utilizadas nas PCA, suas altitudes e vegetações. 


\begin{tabular}{|c|c|c|c|c|c|c|c|c|c|c|c|}
\hline \multicolumn{2}{|c|}{$\begin{array}{l}\text { Legendas das cidades nos gráficos de } \\
\text { PCA }\end{array}$} & \multirow{2}{*}{ 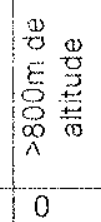 } & \multirow{2}{*}{ 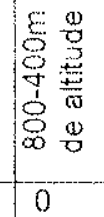 } & \multirow{2}{*}{ 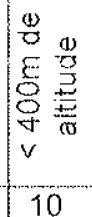 } & \multirow{2}{*}{ 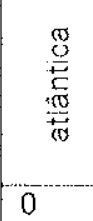 } & \multirow{2}{*}{ 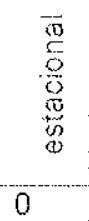 } & \multirow{2}{*}{ 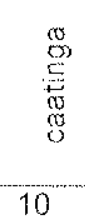 } & \multirow{2}{*}{ 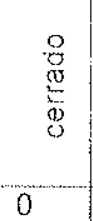 } & \multirow{2}{*}{ 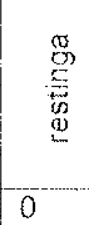 } & \multirow{2}{*}{ 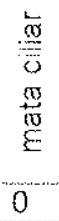 } & \multirow{2}{*}{ 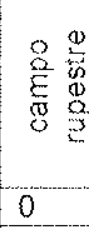 } \\
\hline FSant & FS área antrópica & & & & & & & & & & \\
\hline FScat & Feira Santana, caatinga & 0 & 0 & 10 & 0 & 0 & 10 & 0 & 0 & 0 & 0 \\
\hline FSS J, & FS, Serra de São José & 0 & 0 & 10 & 0 & 0 & 10 & 0 & 0 & 0 & 0 \\
\hline FStotal & Feira de Santana total & 0 & 0 & 10 & 0 & 0 & 10 & 0 & 0 & 0 & 0 \\
\hline Formosa & Formosa do Rio Preto & 0 & 10 & 0 & 0 & 0 & 0 & 10 & 0 & 0 & 0 \\
\hline Gentio d & Gentio do Ouro & 5 & 5 & 0 & 0 & 5 & 5 & 0 & 0 & 0 & 0 \\
\hline Iaçu & laçu & 0 & 5 & 5 & 0 & 0 & 10 & 0 & 0 & 0 & 0 \\
\hline Ibipeba & ibipeba & 10 & 0 & 0 & 0 & 0 & 10 & 0 & 0 & 0 & 0 \\
\hline Ibicoara & lbicoara & 10 & 0 & 0 & 0 & 3 & 0 & 3 & 0 & 3 & 0 \\
\hline lbiraba & ibiraba & 0 & 10 & 0 & 0 & 0 & 10 & 0 & 0 & 0 & 0 \\
\hline $11 \mathrm{~h}$ & Ilhéus & 0 & 0 & 10 & 10 & 0 & 0 & 0 & 0 & 0 & 0 \\
\hline IIhMAt, & Ihéus, Mata Atlântica & 0 & 0 & 10 & 10 & 0 & 0 & 0 & 0 & 0 & 0 \\
\hline llhind & llhéus, indeterminado & 0 & 0 & 10 & & & & & & & \\
\hline Illherest & théus, restinga & 0 & 0 & 10 & 0 & 0 & 0 & 0 & 10 & 0 & 0 \\
\hline Ulhcab & Ilhéus, mata de cabruca & 0 & 0 & 10 & 10 & 0 & 0 & 0 & 0 & 0 & 0 \\
\hline IlhME & Ifh, Mata da Esperança & 0 & 0 & 10 & 10 & 0 & 0 & 0 & 0 & 0 & 0 \\
\hline Ilhomb & llhéus, ombróffila densa & 0 & 0 & 10 & 10 & 0 & 0 & 0 & 0 & 0 & 0 \\
\hline $\mathrm{IIhOI}$ & llhéus, Olivença & 0 & 0 & 10 & 0 & 0 & 0 & 0 & 10 & 0 & 0 \\
\hline IIItotal & lihéus, total & 0 & 0 & 10 & 5 & 0 & 0 & 0 & 5 & 0 & 0 \\
\hline Ipecaetá & Jpecaetá & 0 & 5 & 5 & 5 & 0 & 5 & 0 & 0 & 0 & 0 \\
\hline Irecê & trecê & 5 & 5 & 0 & 0 & 0 & 0 & 0 & 0 & 0 & 0 \\
\hline Itaberab & Itaberaba & 0 & 5 & 5 & 0 & 10 & 0 & 0 & 0 & 0 & 0 \\
\hline Itacaré & Itacaré & 0 & 0 & 10 & 10 & 0 & 0 & 0 & 0 & 0 & 0 \\
\hline Itanag & Itanagra & 0 & 0 & 10 & 10 & 0 & 0 & 0 & 0 & 0 & 0 \\
\hline Itaête & Itaête & 10 & 0 & 0 & 0 & 5 & 5 & 0 & 0 & 0 & 0 \\
\hline Ituaçu & Ituaçu & 5 & 5 & 0 & 0 & 5 & 5 & 0 & 0 & 0 & 0 \\
\hline líuberá & Ituberá & 0 & 0 & 10 & 0 & 10 & 0 & 0 & 0 & 0 & 0 \\
\hline Jac & Jacobina & 5 & 5 & 0 & 0 & 5 & 5 & 0 & 0 & 0 & 0 \\
\hline Jacmc, & Jacobina, mata ciliar & 5 & 5 & 0 & 0 & 0 & 0 & 0 & 0 & 10 & 0 \\
\hline Jactest & Jacobina, estacionais & 5 & 5 & 0 & 0 & 10 & 0 & 0 & 0 & & 0 \\
\hline JacSerC & Jac, Serra do Cruzeiro & 10 & 0 & 0 & 0 & 0 & 0 & 0 & 0 & 0 & 0 \\
\hline Jactotal & Jacobina, total & 5 & 5 & 0 & 0 & 0 & 0 & 0 & 0 & 0 & 0 \\
\hline Jequié & Jequié & 0 & 5 & 5 & 0 & 0 & 10 & 0 & 0 & 0 & 0 \\
\hline Joazeir & Joazeiro & 0 & 0 & 10 & 0 & 0 & 10 & 0 & 0 & 0 & 0 \\
\hline Jussari & Jussari & 0 & 0 & 10 & 5 & 5 & 0 & 0 & 0 & 0 & 0 \\
\hline $\mathrm{LaP}$ & Lamaräo do Passe & 0 & 0 & 10 & 0 & 0 & 0 & 0 & 5 & 5 & 0 \\
\hline LaPind & La $P$, indeterminado & 0 & 0 & 10 & & & & & & & \\
\hline LaP1 & Lamarão $\mathrm{P}$, ponto 1 & 0 & 0 & 10 & 0 & 0 & 0 & 0 & 0 & 10 & 0 \\
\hline LaPtotal & Lamarão Passe, total & 0 & 0 & 10 & 0 & 0 & 0 & 0 & 5 & 5 & 0 \\
\hline Len & Lençóis & 10 & 0 & 0 & 0 & 5 & 0 & 0 & 0 & 0 & 5 \\
\hline LenBo, & Lençóis, Boqueirăo & 10 & 0 & 0 & 0 & 10 & 0 & 0 & 0 & 0 & 0 \\
\hline Lencr, & Len, campo rupestre & 10 & 0 & 0 & 0 & 0 & 0 & 0 & 0 & 0 & 10 \\
\hline Lenfoz & Len, foz do Capivara & 10 & 0 & 0 & 0 & 0 & 0 & 0 & 0 & 10 & 0 \\
\hline Lenmc, & Lençóis, mata ciliar & 10 & 0 & 0 & 0 & 0 & 0 & 0 & 0 & 10 & 0 \\
\hline Lentbd, & Lençóis, trilha do Bodão & 10 & 0 & 0 & 0 & 0 & 0 & 0 & 0 & 10 & 0 \\
\hline SeChest & $\begin{array}{l}\text { Lençóis, Serra da } \\
\text { Chapadinha, mata ciliar }\end{array}$ & 10 & 0 & 0 & 0 & 0 & 0 & 0 & 0 & 10 & 0 \\
\hline SeChgrt & $\begin{array}{l}\text { Len, Serra Chapadinha, } \\
\text { mata de grotão }\end{array}$ & 10 & 0 & 0 & 0 & 0 & 0 & 0 & 0 & 10 & 0 \\
\hline SeChtota & $\begin{array}{l}\text { Lençóis, Serra da } \\
\text { Chapadinha total }\end{array}$ & 10 & 0 & 0 & 0 & 0 & 0 & 0 & 0 & 10 & 0 \\
\hline Lentotal & Lencóis, Lençois total & 10 & 0 & 0 & 0 & 3 & 0 & 0 & 0 & 3 & 3 \\
\hline Lenfech & Lençóis, fechado & 10 & 0 & 0 & 0 & 0 & 0 & 0 & 0 & 10 & 0 \\
\hline Maracás & Maracás & 0 & 5 & 5 & 0 & 0 & 10 & 0 & 0 & 0 & 0 \\
\hline Maraú & Maraú & 0 & 0 & 10 & 10 & 0 & 0 & 0 & 0 & 0 & 0 \\
\hline 2IrmPE & Mata Dois Irmãos, PE & 0 & 0 & 10 & & & & & & & \\
\hline Mata de & Mata de São Joấo & 0 & 0 & 10 & 10 & 0 & 0 & 0 & 0 & 0 & 0 \\
\hline MiC & Miguel Calmon & 5 & 5 & 0 & 0 & 0 & 0 & 0 & 0 & 5 & 5 \\
\hline MiCcr, & MiC, campo rupestre & 5 & 5 & 0 & 0 & 0 & 0 & 0 & 0 & 0 & 10 \\
\hline
\end{tabular}

Tabela 10 (cont.) - Abreviações das "localidades" utilizadas nas PCA, suas altitudes e vegetações. 


\begin{tabular}{|c|c|c|c|c|c|c|c|c|c|c|c|}
\hline Legendas d & $\begin{array}{l}\text { S cidades nos gráficos de } \\
\text { PCA }\end{array}$ & 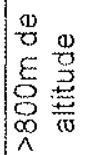 & 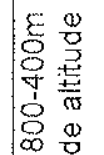 & 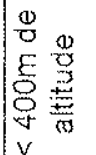 & 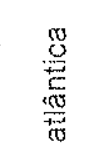 & 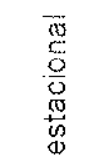 & 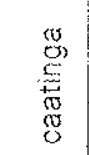 & 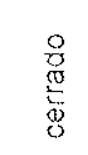 & 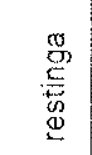 & 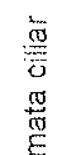 & 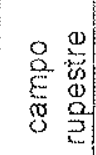 \\
\hline MiCgal, & MiC, floresta galeria & 5 & 5 & 0 & 0 & 0 & 0 & 0 & 0 & 10 & 0 \\
\hline Micind & MiC,indeterminado & 5 & 5 & 0 & & & & & & & \\
\hline Mictotal & Miguel Calmon total & 5 & 5 & 0 & 0 & 0 & 0 & 0 & 0 & 5 & 5 \\
\hline Morporá & Morporá & 0 & 10 & 0 & 0 & 3 & 3 & 3 & 0 & 0 & 0 \\
\hline MC & Morro do Chapéu & 10 & 0 & 0 & 0 & 5 & 5 & 0 & 0 & 0 & 0 \\
\hline MCind & MC, indeterminado & 10 & 0 & 0 & & & & & & & \\
\hline MCcrup & $\mathrm{MC}$, campo rupestre & 10 & 0 & 0 & 0 & 0 & 0 & 0 & 0 & 0 & 10 \\
\hline MCcat & $M C_{1}$ caatinga & 10 & 0 & 0 & 0 & 0 & 10 & 0 & 0 & 0 & 0 \\
\hline MCmc & MC, mata ciliar & 10 & 0 & 0 & 0 & 0 & 0 & 0 & 0 & 10 & 0 \\
\hline MCtotal & $M C$, total & 10 & 0 & 0 & 0 & 0 & 3 & 0 & 0 & 3 & 3 \\
\hline Mu & Mucugê & 10 & 0 & 0 & 0 & 0 & 0 & 0 & 0 & 0 & 0 \\
\hline Mucam & Mucugê, campos gerais & 10 & 0 & 0 & 0 & 0 & 0 & 0 & 0 & 0 & -10 \\
\hline Mucrup & Mucug, campo rupestre & 10 & 0 & 0 & 0 & 0 & 0 & 0 & 0 & 0 & 10 \\
\hline Muind & Mucugê, indeterminado & 10 & 0 & 0 & 0 & 0 & 0 & 0 & 0 & 0 & 0 \\
\hline Mutran & Mucugê, transição & 10 & 0 & 0 & 0 & 0 & 0 & 0 & 0 & 0 & \\
\hline Mutotal & Mucugê, total & 10 & 0 & 0 & 0 & 0 & 0 & 0 & 0 & 0 & \\
\hline Mundo No & Mundo Novo & 0 & 10 & 0 & 0 & 5 & 5 & 0 & 0 & 0 & 0 \\
\hline $\mathrm{Pal}$ & Palmeiras & 10 & 0 & 0 & 0 & 0 & 0 & 5 & 0 & 0 & 5 \\
\hline Palcal, & Pal, cerrado de altitude & 10 & 0 & 0 & 0 & 0 & 0 & 0 & 0 & 0 & 10 \\
\hline PalPlce, & Pal, Pai Inácio, cerrado & 10 & 0 & 0 & 0 & 0 & 0 & 10 & 0 & 0 & 0 \\
\hline Paulo Af & Paulo Afonso & 0 & 0 & 10 & 0 & 5 & 5 & 0 & 0 & 0 & 0 \\
\hline Pilão $\mathrm{Ar}$ & Piläo Arcado & 0 & 10 & 0 & 0 & 0 & 10 & 0 & 0 & 0 & 0 \\
\hline Pindubac & Pindubaçu & 5 & 5 & 0 & 0 & 10 & 0 & 0 & 0 & 0 & 0 \\
\hline Porto Se & Porto Seguro & 0 & 0 & 10 & 5 & 0 & 0 & 0 & 5 & 0 & 0 \\
\hline Prd & Prado & 0 & 0 & 10 & 10 & 0 & 0 & 0 & 0 & 0 & 0 \\
\hline Prdgrt, & Prado, mata de grotão & 0 & 0 & 10 & 0 & 0 & 0 & 0 & 0 & 10 & 0 \\
\hline Prdrest & Prado, Prado, restinga & 0 & 0 & 10 & 0 & 0 & 0 & 0 & 10 & 0 & 0 \\
\hline Prdtotal & Prado, Prado total & 0 & 0 & 10 & 0 & 0 & 0 & 0 & 5 & 5 & 0 \\
\hline Raso da & Raso da Catarina & 0 & 10 & 0 & 0 & 0 & 10 & 0 & 0 & 0 & 0 \\
\hline Remanso & Remanso & 0 & 10 & 0 & 0 & 0 & 10 & 0 & 0 & 0 & 0 \\
\hline $\mathrm{RiP}$ & Ribeira do Pombal & 0 & 5 & 5 & 0 & 0 & 10 & 0 & 0 & 0 & 0 \\
\hline RiPcat & Ribeira $P$, caatinga & 0 & 5 & 5 & 0 & 0 & 10 & 0 & 0 & 0 & 0 \\
\hline RiPeco & Ribeira $P$, ecótono & 0 & 5 & 5 & 0 & 0 & 5 & 0 & 0 & 0 & 0 \\
\hline RiPtotal & Ribeira do Pombal total & 0 & 5 & 5 & 0 & 0 & 5 & 0 & 0 & 0 & 0 \\
\hline $\mathrm{RC}$ & Rio das Contas & 10 & 0 & 0 & 0 & 0 & 3 & 3 & 0 & 0 & 3 \\
\hline RCcrup & $\mathrm{RC}$, campo rupestre & 10 & 0 & 0 & 0 & 0 & 0 & 0 & 0 & 0 & 10 \\
\hline RCtotal & Rio Contas total & 10 & 0 & 0 & 0 & 0 & 3 & 3 & 0 & 0 & 3 \\
\hline Rodelas & Rodelas & 0 & 5 & 5 & 0 & 0 & 10 & 0 & 0 & 0 & 0 \\
\hline Ruy Barb & Ruy Barbosa & 0 & 5 & 5 & 0 & 5 & 0 & 0 & 0 & 5 & 0 \\
\hline Salvador: & Salvador & 0 & 0 & 10 & 0 & 0 & 0 & 0 & 0 & 0 & 0 \\
\hline Abaete S & dunas do Abaeté & 0 & 0 & 10 & 0 & 0 & & 0 & & 0 & 0 \\
\hline aeroport & dunas do aeroporto & 0 & 0 & 10 & 0 & 0 & & 0 & & 0 & 0 \\
\hline Itapaero & dunas ltapã + aeropotto & 0 & 0 & 10 & 0 & 0 & & 0 & & 0 & 0 \\
\hline Itapoa S & dunas de Itapōa & 0 & 0 & 10 & 0 & 0 & & 0 & & 0 & 0 \\
\hline SSC & Santa Cruz Cabrália & 0 & 0 & 10 & 10 & 0 & 0 & 0 & 0 & 0 & 0 \\
\hline ScCvera, & SCC, Estaçăo Veracruz & 0 & 0 & 10 & 10 & 0 & 0 & 0 & 0 & 0 & 0 \\
\hline ScComb & SCC, ombrófila densa & 0 & 0 & 10 & 10 & 0 & 0 & 0 & 0 & 0 & 0 \\
\hline SCCcedro, & SCC, projeto CEDRO & 0 & 0 & 10 & & & & & & & \\
\hline SCCrest, & SCC, restinga & 0 & 0 & 10 & 0 & 0 & 0 & 0 & 10 & 0 & 0 \\
\hline SCCES, & SCC, ESPAB & 0 & 0 & 10 & 10 & 0 & 0 & 0 & 0 & 0 & 0 \\
\hline SCCind & $S C C$, indeterminado & 0 & 0 & 10 & & & & & & & \\
\hline SCCtotal & SCC, total & 0 & 0 & 10 & 5 & 0 & 0 & 0 & 5 & 0 & 0 \\
\hline StaTer & Santa Terezinha, Serfa & 0 & 10 & 0 & 0 & 0 & 10 & 0 & 0 & 0 & 0 \\
\hline SDesid & São Desidério & 5 & 5 & 0 & 0 & 0 & 0 & 10 & 0 & 0 & 0 \\
\hline SFracon & Săo Francisco Conde & 0 & 0 & 10 & 10 & 0 & 0 & 0 & 0 & 0 & 0 \\
\hline SSP & São Sebastião Passe & 0 & 0 & 10 & 5 & 0 & 0 & 0 & 5 & 0 & 0 \\
\hline SSPrest & SSP, restinga antrópica & 0 & 0 & 10 & 0 & 0 & 0 & 0 & 10 & 0 & 0 \\
\hline SSPpars, & SSP, Panema & 0 & 0 & 10 & 10 & 0 & 0 & 0 & 0 & 0 & 0 \\
\hline SSPpaind, & SSP, $P$ indeterminado & 0 & 0 & 10 & & & & & & & \\
\hline
\end{tabular}

Tabela 10 (cont.) - Abreviações das "localidades" utilizadas nas PCA, suas altitudes e vegetações. 


\begin{tabular}{|c|c|c|c|c|c|c|c|c|c|c|c|}
\hline \multicolumn{2}{|c|}{$\begin{array}{l}\text { Legendas das cidades nos gráficos de } \\
\text { PCA }\end{array}$} & \multirow{2}{*}{ 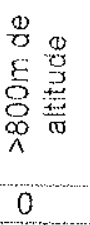 } & \multirow{2}{*}{ 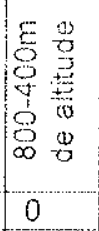 } & \multirow{2}{*}{ 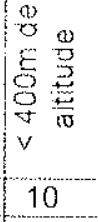 } & \multirow{2}{*}{ 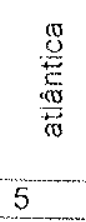 } & \multirow{2}{*}{ 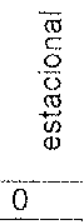 } & \multirow{2}{*}{ 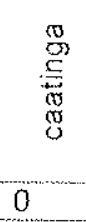 } & \multirow{2}{*}{$\begin{array}{l}8 \\
8 \\
0 \\
0 \\
0 \\
0 \\
0\end{array}$} & \multirow{2}{*}{ 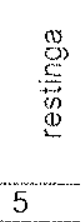 } & \multirow{2}{*}{ 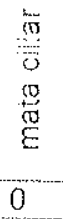 } & \multirow{2}{*}{ 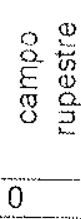 } \\
\hline SSPtotal & SSP, total & & & & & & & & & & \\
\hline Simões & Simóes Filho & 0 & 0 & 10 & & & & & & & 0 \\
\hline Tucano & Tucano & 0 & 10 & 0 & 0 & 0 & 10 & 0 & 0 & 0 & 0 \\
\hline Uauá & Uauá & 0 & 10 & 0 & 0 & 0 & 10 & 0 & 0 & 0 & 0 \\
\hline $\mathrm{U}$ & Una & 0 & 0 & 10 & 10 & 0 & 0 & 0 & 0 & 0 & 0 \\
\hline UESMAI & Una, ESMAl & 0 & 0 & 10 & 10 & 0 & 0 & 0 & 0 & 0 & 0 \\
\hline UMAt & Una, Mata Attântica & 0 & 0 & 10 & 10 & 0 & 0 & 0 & 0 & 0 & 0 \\
\hline UREBIO & Una, REBIO & 0 & 0 & 10 & 10 & 0 & 0 & 0 & 0 & 0 & 0 \\
\hline Uind & Una indeterminado & 0 & 0 & 10 & & & & & & & 0 \\
\hline Utotal & Una total & 0 & 0 & 10 & 10 & 0 & 0 & 0 & 0 & 0. & 0 \\
\hline Uruçuca & Uruçuca & 0 & 0 & 10 & 10 & 0 & 0 & 0 & 0 & 0 & 0 \\
\hline Valença & Valença & 0 & 0 & 10 & 0 & 0 & 0 & 0 & 10 & 0 & 0 \\
\hline VC & Vera Cruz & 0 & 0 & 10 & 3 & 0 & 0 & 0 & 3 & 3 & 0 \\
\hline Vcind & VC indeterminado & 0 & 0 & 10 & & & & & & & \\
\hline VCtotal & Vera Cruz total & 0 & 0 & 10 & 3 & 0 & 0 & 0 & 3 & 3 & 0 \\
\hline Vitória & Vitória da Conquista & 10 & 0 & 0 & 0 & 5 & 5 & 0 & 0 & 0 & 0 \\
\hline Wagner & Wagner & 10 & 0 & 0 & 0 & 10 & 0 & 0 & 0 & 0 & 0 \\
\hline Xique- $X i$ & Xique-Xique & 0 & 10 & 0 & 0 & 0 & 10 & 0 & 0 & 0 & 0 \\
\hline Wencesl & Wenceslau Guimarães & 0 & 5 & 5 & 5 & 0 & 0 & 0 & 0 & 5 & 0 \\
\hline \multirow{2}{*}{\multicolumn{12}{|c|}{$\begin{array}{l}\text { Localidades } \\
\text { em estudo: }\end{array}$}} \\
\hline & 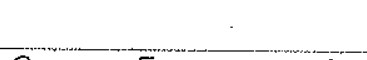 & & & & & & & & & & \\
\hline $\begin{array}{l}\text { CAM } \\
\text { FORM }\end{array}$ & $\begin{array}{l}\text { Campo Formoso após } \\
\text { morfotipos }\end{array}$ & 0 & 10 & 0 & & $?$ & $?$ & $? ?$ & & $?$ & \\
\hline CFOrm & Campo Formoso final & 0 & 10 & 0 & & $?$ & $?$ & $? ?$ & & $?$ & \\
\hline Pacui & Afloramento Pacui & 0 & 10 & 0 & & $?$ & $?$ & $? ?$ & & $?$ & \\
\hline FazBen & Afl. Fazenda Bento & 0 & 10 & 0 & & $?$ & $?$ & $? ?$ & & $?$ & \\
\hline SALG & Afloramento Salgadinho & 0 & 10 & 0 & & $?$ & $?$ & $? ?$ & & $?$ & \\
\hline
\end{tabular}

Tabela 10 (cont.) - Abreviações das "localidades" utilizadas nas PCA, suas altitudes e vegetações.

É importante ressaltar que a formação de cada eixo é diferente em cada análise, visto que o eixo em si é determinado durante o processo de análise multivariada dos dados, pelo programa de estatística, procurando estabelecer as causas das variações desses dados. Posteriormente serão comparadas algumas vegetações para confirmar ou não as análises isoladas, pois a grande preocupação foi estabelecer a reprodutividade da estatística para o caso de estudos em vegetações nas regiões próximas à Bahia.

Como algumas análises são de dificil interpretação, as características isoladamente, foram examinadas para melhor definição de variações. Em aglumas delas foram acrescentados dados de altitude, conforme tabela 10 . 


\section{2 - Análises por tipo vegetacional}

\subsection{1 - Bioma cerrado}

A análise da vegetação de cerrado está representada por menor número de "localidades" devido ao maior território dos municípios do oeste da Bahia, onde esta vegetação predomina. Formosa do Rio Preto, localizado no limite norte do bioma cerrado, distanciou-se das demais, pela freqüência de ápices emarginados e apenas $42 \%$ das espécies sem dentes nas margens foliares. $O$ ápice emarginado pode ser ocasionado por condições ambientais desfavoráveis.

Foi possível diferenciar as "localidades" que apresentam o contato do cerrado com floresta estacional das demais "localidades", assim como leve distinção entre o cerrado próximo ao Estado de Goiás daquele mais próximo ao Estado de Minas Gerais, este em contato com a caatinga.

De qualquer forma, a assembléia fóssil de Campo Formoso aparenta não guardar muitas semelhanças fisionômicas com a vegetação de cerrado presente na Bahia.

\subsection{2 - Bioma Complexo Atlàntico}

Na análise da vegetação do Complexo Atlântico, muitas "localidades" estavam disponíveis, principalmente quando se associam as denominadas florestas ombrófilas densas que ocorrem mais para o nordeste da Bahia. O eixo 1 da análise do Complexo Atlântico exibe quase os mesmos parâmetros da análise global, inclusive com os mesmos valores relativos. Pode-se perceber então, a grande relevância do complexo atlântico na análise global, justificando a análise das vegetações separadamente.

\subsection{3 - Bioma Caatinga}

$\mathrm{Na}$ análise da vegetação da Caatinga, muitas "localidades" estavam disponíveis e bem distribuídas ao longo do Estado da Bahia assim, tendo sido possível documentá-la no contato com quase todos os tipos vegetacionais. No total foram utilizadas 39 "localidades" para comparação com a assembléia fóssil de Campo Formoso, atualmente localizado em área de ocorrência de caatinga (Gráfico 2).

A PCA pode individualizar as "localidades" com contatos vegetacionais, com exceção de Ituaçu, Bom Jesus da Lapa e Xique-Xique, "localidades" nas quais a caatinga faz contato com floresta estacional. Essas "localidades", situadas em regiões mais elevadas, estão agrupadas mas não separadas de outras apenas com caatinga. Nesta PCA, nem todos os aspectos fisionômicos puderam ser explicados. 


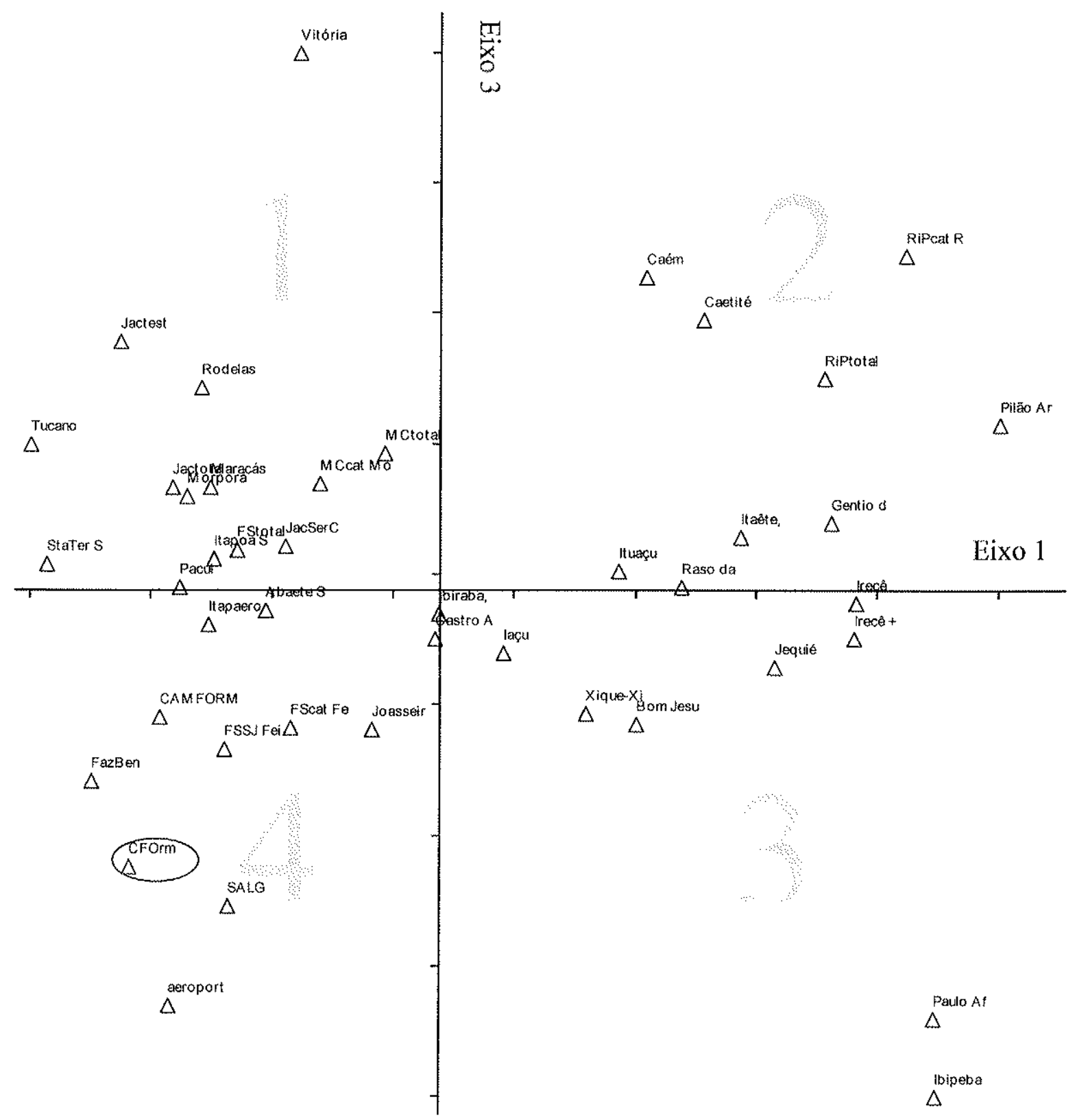

Gráfico 2 - Análise da vegetação de caatinga e regiões de contato: PCA de 39 "localidades" para comparação com a assembléia fóssil de Campo Formoso. Eixos 1 e 3, porque o eixo 2 representa apenas a assembléia fóssil. Abreviações na tabela 10.

Paulo Afonso e Ibipeba, localizadas muito distantes das outras "localidades", tiveram seus problemas revelados: Ibipeba não está bem representada (apenas 9 espécies) e Paulo Afonso teve suas classes de tamanho erroneamente digitadas, indicando que erros nos dados podem ser revelados na análise, demonstando a confiabilidade do método, embora a interpretação dos dados nem sempre esteja clara. 


\subsection{4 - Floresta estacional}

A floresta estacional pode ou não ser considerada como bioma, conforme comentado no capitulo 2. Caracterizada pela decidualidade sazonal de seus elementos, é classificada como semidecídua ou decídua de acordo com o porcentual de espécies que exibem decidualidade. Também é chamada de floresta caducifólia não espinhosa, podendo ser bem similar a algumas fisionomias da caatinga. Mesmo com certo grau de incerteza na classificação da floresta estacional pelo herbário ALCB, considera-se a análise particularizada bastante significativa devido ao grande número de "localidades" descritas como estacionais.

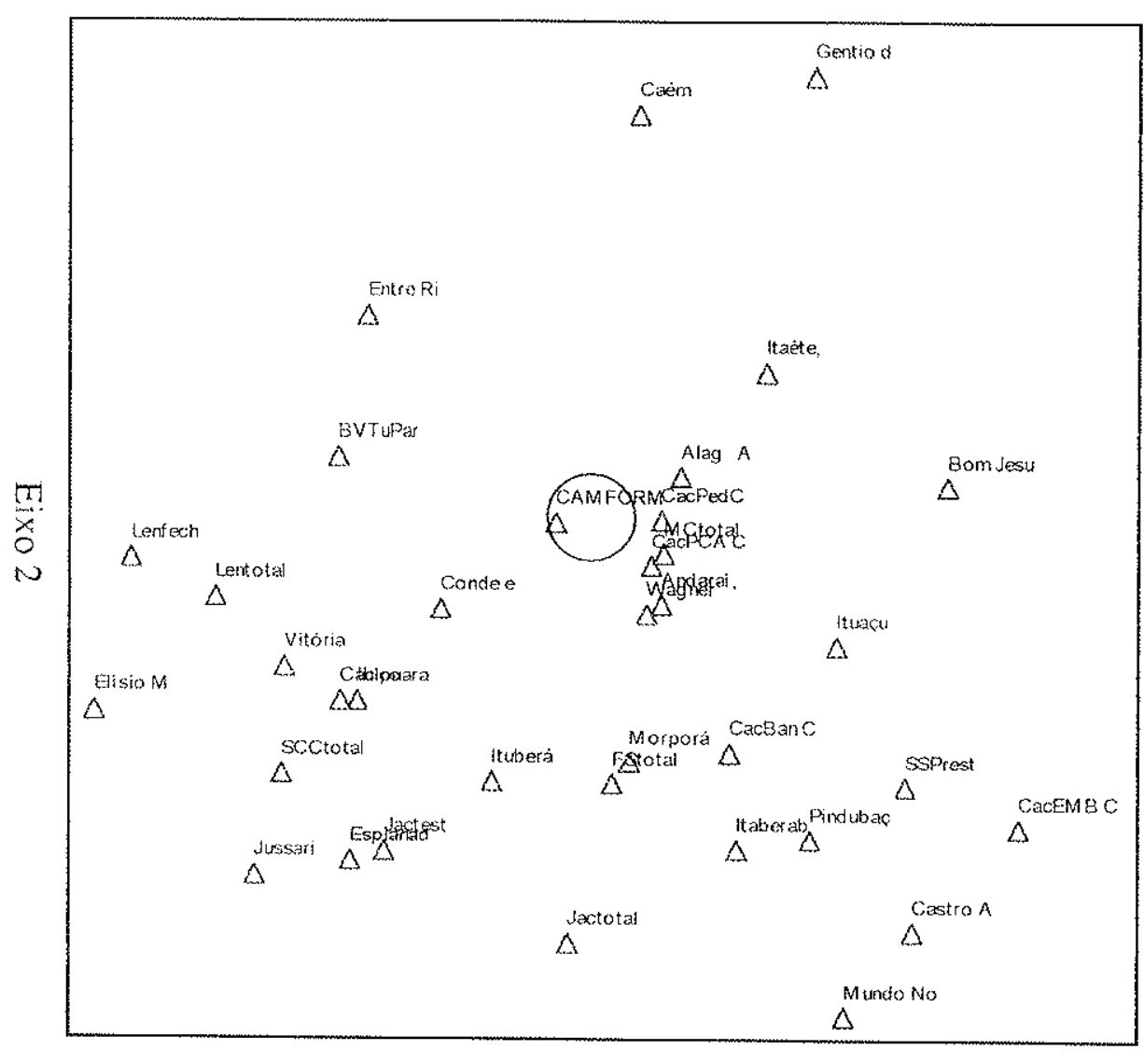

Eixo 1

Gráfico 3 - Análise da vegetação de floresta estacional e regiões de contato: PCA de 34 "localidades" para comparação com a assembléia fóssil de Campo-Formoso. Eixos 1 e 2. Abreviações na tabela 10 .

O eixo 1 da PCA corresponde ao eixo 1 da análise global, incluindo valores de importância relativa, com apenas uma exceção: ao invés de utilizar base arredondada ou aguda, como ocorre na análise global, utiliza-se apenas a base aguda. Este resultado é muito importante por demonstrar que a fisionomia foliar reflete a fisionomia da vegetação e que quase nunca os biomas são uniformes em suas físionomias. Por comparação, esse eixo pode ser considerado como representativo da umidade. 
O eixo 2 da análise também é bem similar ao eixo 2 da análise global, com algumas exceçōes ou mudanças dos valores das importâncias relativas dos paràmetros utilizados. A ocorrencia de margem foliar com dentes é de importância tăo alta quanto na análise global, mas a margem lobada perde representatividade na formação do eixo. As classes de tamanho continuam sendo as maiores, mas meso $l 1$ é menos significativa enquanto que a classe micro lll possui maior representatividade. O ápice emarginado não é representado na extremidade negativa e os tipos de base cordada ou arredonda são menos relevantes.

Essas pequenas diferenças basicamente não alteram a disposição das "localidades" em relação a esses dois eixos, que podem ter sido alterados pela inclusão das "localidades" com menos de 20 espécies documentadas, conforme observado no gráfico 3.

Existe distanciamento de algumas "localidades" nas quais a floresta estacional encontra-se em contato com a vegetação de caatinga, mas não para todas. É dificil correlacionar esta distribuição com aspectos geográficos, pois Boa Vista do Tupim, por exemplo, e Itaberaba, estariam em condições muito similares e estão bem afastadas no gráfico 3. Portanto, para melhor compreensão desta vegetação, torna-se necessário utilizar o eixo 3 da PCA, bem caracterizado pela presença de ápice arredondado e também base arredondado na extremidade negativa. A extremidade positiva, no entanto, é caracterizada pela relação de delgadeza menor que $1: 1$. Embora de dificil compreensão, esse eixo acarreta a formação de três agrupamentos de "localidades", conforme indica o gráfico 4 .

No agrupamento denominado I encontram-se as "localidades" nas quais a floresta estacional está em contato com a vegetação de caatinga. Estas "localidades" estão nas proximidades da Chapada Diamantina. O clima varia de semi-árido a úmido-subúmido, segundo a classificação do SEI. Nesta análise, ao contrário do esperado, o tipo climático não corresponde ao principal fator de agrupamento provavelmente devido a grandes variações na estrutura da vegetação. $O$ Estado da Bahia representa, de fato, o encontro de três grandes biomas brasileiros. Baseando-se nesta análise optou-se pela inclusão do caráter altitude, conforme anteriormente comentado.

No agrupamento denominado II, concentra-se o maior número de "localidades" com vegetação exclusivamente de floresta estacional e algumas "localidades" com a floresta estacional em contato com a vegetação de caatinga. Exibem clima semi-árido a subúmido-seco e localizam-se na porção centromorte da Bahia, em altitudes intermediárias. Morporá constitui exceção, tanto de localização quanto de tipo de vegetação, já que a floresta estacional encontra-se em contato com a vegetação de cerrado. 


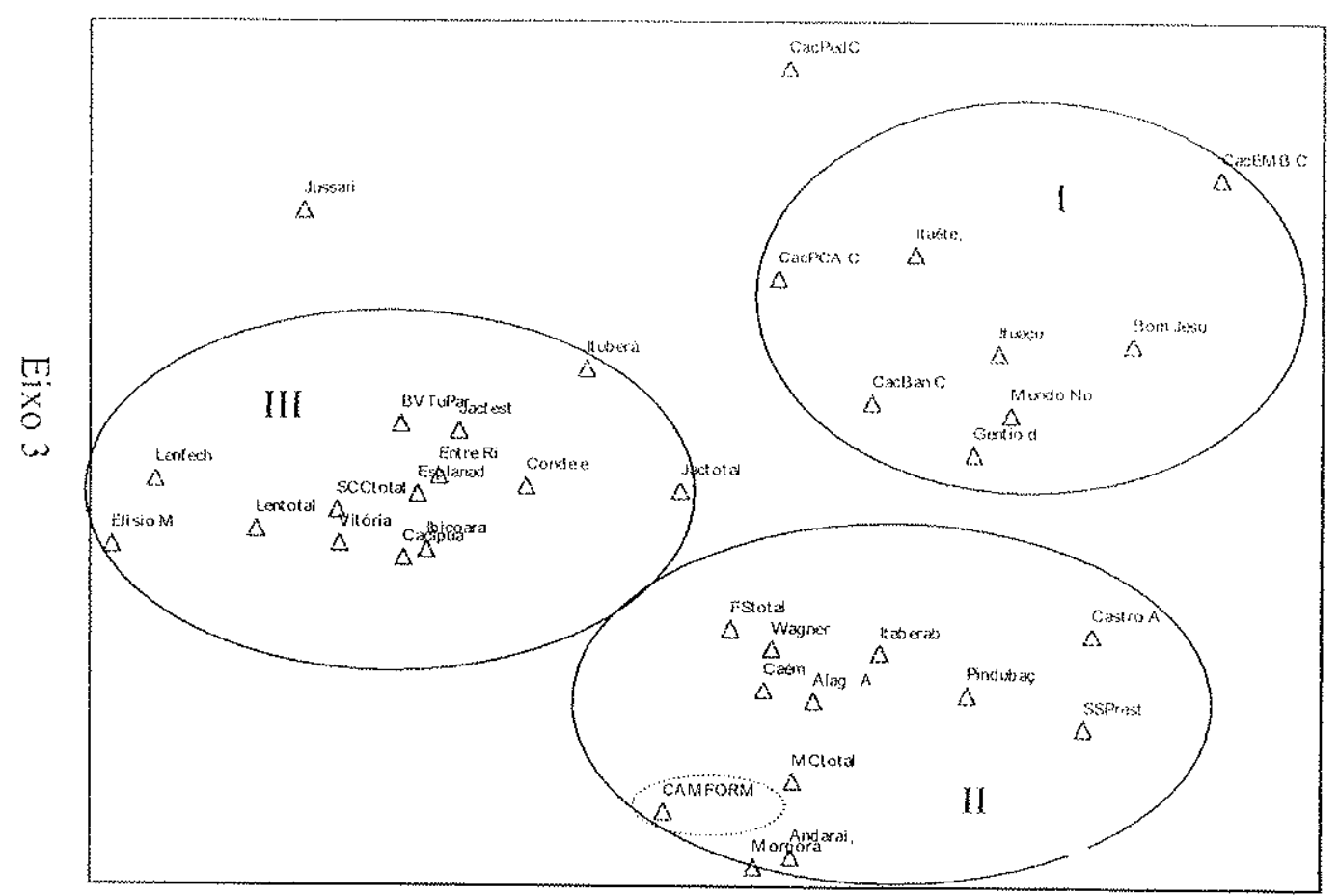

Eixo 1

Gráfico 4 - Análise da vegetação de floresta estacional e regiões de contato: PCA de 34 "localidades" para comparação com a assembléia fóssil de Campo Formoso. Eixos 1 e 3. Abreviações na tabela 10 .

O agrupamento III, distribuído na região central do eixo 3, concentra a maior parte das "localidades" que possuem contato da floresta estacional com floresta ombrófila. O clima dessas "localidades" varia de úmido a úmido-subúmido, mas também subúmido-seco, como no caso de Boa Vista do Tupim apenas com floresta estacional e de Jacobina, que são únicas pela situação em altitudes intermediárias. Interessante neste gráfico é o posicionamento da assembléia fóssil de Campo Formoso nas proximidades do maior agrupamento.

\section{3 - Análises por características}

Na tentativa de melhor compreender estas vegetações, realizou-se PCA de características mais específicas, procurando identificar a variação de cada parâmetro. Nestas análises, retirou-se algumas "localidades" da vegetação higrófila sul-baiana, para evitar concentrar as características desta vegetação muito bem representada.

Correlacionou-se os caracteres referentes à margem foliar e as classes de tamanho, dois parâmetros normalmente interpretados como diretamente relacionado ao clima. O PCA destas características encontramse representado no gráfico 5. 
O eixo 1 é constituído pela presença de margem sem dentes e classes de tamanho micro III e meso I em sua extremidade negativa. Essas características são comumente associadas a clima úmido e/ou vegetação fechada. O eixo 2 também é constituído pela presença de margem sem dentes, mas pelas menores classes de tamanho, fazendo com que não ocorram "localidades" distribuídas na porção inferior esquerda do gráfico. A melhor caracterização desse eixo ocorre pela extremidade positiva constituída pela presença de dentes regulares e próximos associados a classes de tamanho maiores que micro III. Essa associação estaria melhor representando vegetações fechadas. O gráfico não mostra agrupamento nítido entre as diferentes vegetações.

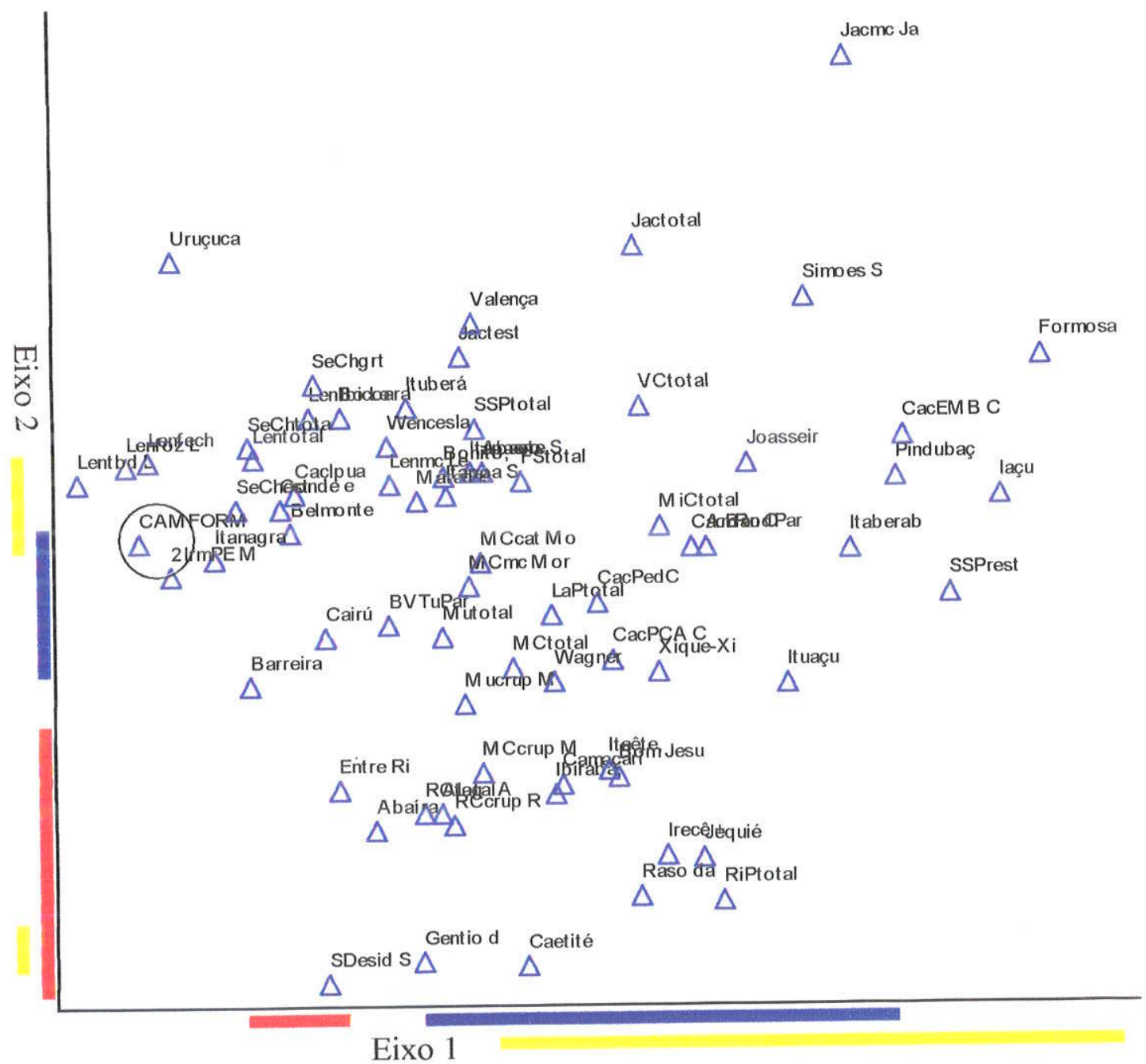

Gráfico 5 - Tipos de margem foliar e classes de tamanho: PCA de 72 "localidades" para comparação com a assembléia fóssil de Campo Formoso. Eixos 1 e 2. Abreviações na tabela 10. Vermelho para cerrado, azul para estacional e amarelo para caatinga. 
Para melhor distinção da distribuiçăo de cada tipo vegetacional, "localidades" de diferentes vegetações foram projetadas diretamente em cada eixo. As distribuiçōes se sobrepõem, mas mostram espectro diferenciado. Não foram projetadas, contudo, as "localidades" com mais de uma vegetação porque elas estariam nos limites de sua distribuição, não caracterizando as condições normais do tipo vegetacional

Interpretando essas distribuições em função da formação de cada eixo, pode-se dizer que as "localidades" de cerrado possuem maior disponibilidade hídrica para as plantas. As distribuições da floresta estacional e da caatinga se sobrepõem, mas a vegetação de caatinga teria menor disponibilidade hídrica, fatos bem aceitos. O cerrado, presente na Bahia, teria como característica, estruturas fisionômicas mais abertas que a estrutura da floresta estacional. A caatinga apresenta distribuição dispersa nos gráfico, podendo possuir estrutura aberta assim como estrutura ainda mais fechada que floresta estacional. Entretanto, estas interpretações estão baseadas na análise clássica das características foliares. Aparentemente, as diferentes adaptações fisiológicas das espécies de caatinga poderiam resultar em folhas condicionadas por outras caracteristicas. De fato, foram essas características diferenciadas que induziram a realização da análise físionômica da vegetação da Bahia. Observou-se que espécies presentes no ALCB exibiam folhas que se tornavam menores à medida que a vegetação de caatinga tornava-se mais fechada.

Em outra análise, correlacionou-se o tamanho foliar com a relação de delgadeza nas diferentes vegetações. A floresta estacional exibe ampla variedade de formas foliares, mas nenhum padrão pode ser estabelecido com apenas estes critérios. Como seria esperado, as folhas maiores e mais largas são encontradas principalmente em vegetações do Complexo Vegetacional Atlântico. Folhas menores e mais estreitas ocorrem nos biomas cerrado e caatinga. No entanto, esses agrupamentos ainda não permitem distinção nítida entre os diferentes biomas.

Ainda tentando melhor estabelecer os parâmetros morfológicos, procurou-se analisar separadamente a forma foliar propriamente dita com os diferentes tipos de extremidades foliares de ápice e de base, realizando outra PCA, representada no gráfico 6 . O eixo 1 é definido pela presença de ápice atenuado, base arredondada e forma elíptica na extremidade negativa e forma oval, ápice agudo e base cordada na extremidade positiva. O eixo 2 é constituído pela presença de base aguda e forma oboval na extremidade negativa e pela presença de base arredondada ou cordada associada a ápice arredondado na extremidade positiva.

Embora não sejam as características mais marcantes nas análises multivariadas que já foram testadas, essas características permitiram agrupamentos interessantes. O agrupamento I inclui folhas elípticas com extremidades arredondadas, correspondendo as formas foliares mais comumente encontradas no Estado da Bahia, incluindo diferentes tipos vegetacionais. O agrupamento II 
também corresponde a um tipo foliar comum, diferente do anterior por apresentar folhas ovais. Estudando as diferentes "localidades", observa-se a presença da relação de delgadeza predominantemente 1-2:1 e que elas estão sujeitas a climas um pouco mais úmidos que o agrupamento anterior.

O agrupamento III inclui maior variedade de formas foliares e reúne vegetações próximas ao litoral ou em matas de grotão nas proximidades da Chapada Diamantina. O agrupamento IV contem maior porcentual de folhas ovais com base cordada e ápice agudo e reúne "localidades" nas quais a caatinga está em contato com vegetações mais úmidas. Os agrupamentos V e VI são formados por "localidades" úmidas, embora apresentem formas foliares diferenciadas. O agrupamento V possui folhas elípticas com base arredondada e ápice atenuado enquanto o VI, folhas predominantemente obovais com ápices arredondados e bases agudas.

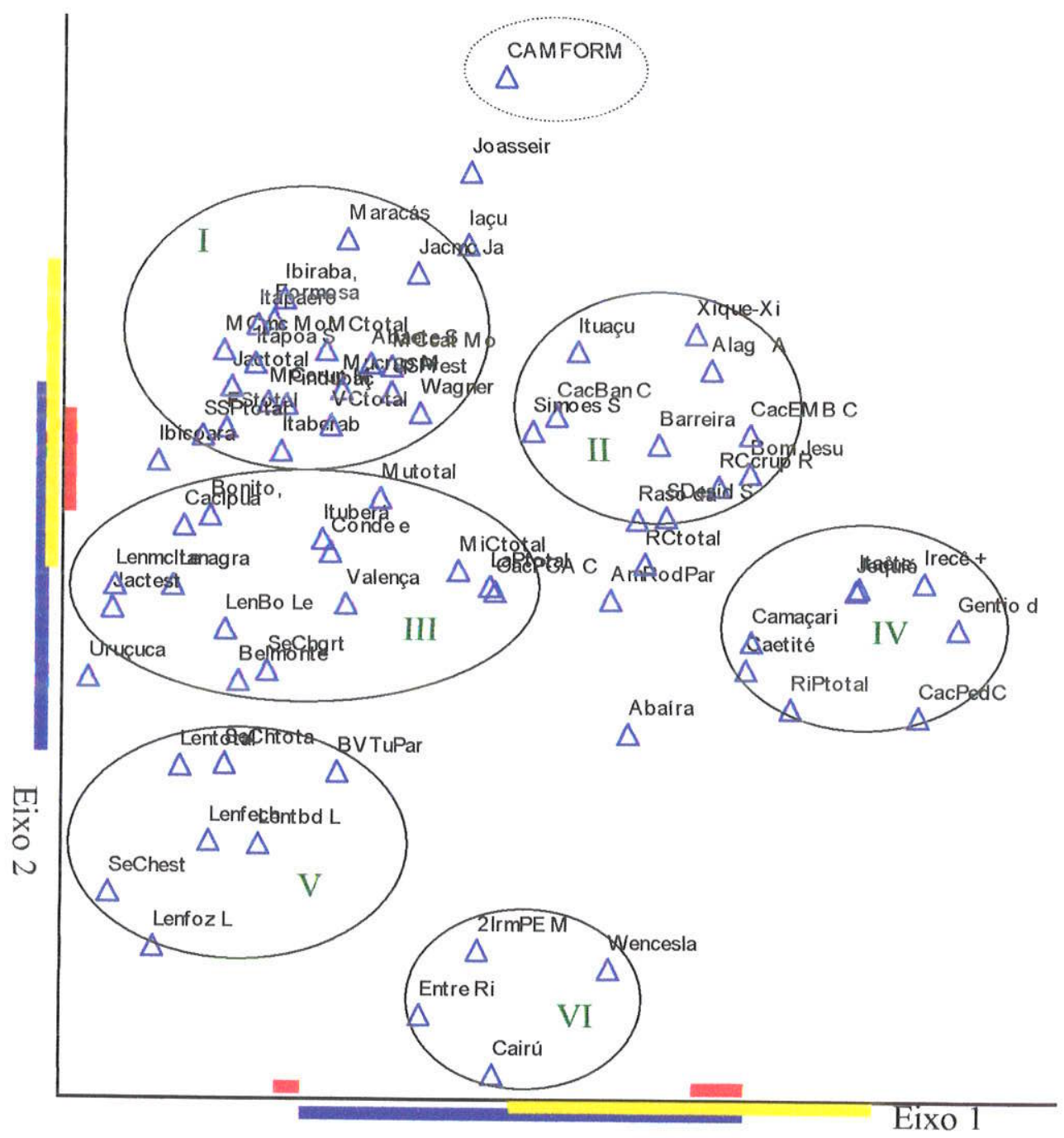

Gráfico 6 - Forma foliar e tipos de ápice e de base: PCA de 72 "localidades" para comparação com a assembléia fóssil de Campo Formoso. Eixos 1 e 2. Abreviações na tabela 10. Vermelho para cerrado, azul para estacional e amarelo para caatinga 
$\dot{E}$ interessante observar que a assembléia fóssil de Campo Formoso não se posiciona em nenhum desses agrupamentos.

Em geral, analisando-se a representatividade de cada eixo em cada análise diferenciada, torna-se possível dizer que a vegetação de cerrado é a que apresenta características mais próprias, mais restritas, talvez porque sua distribuição não seja tão ampla no Estado da Bahia. A tabela 11 ilustra as comparações:

\begin{tabular}{|c|c|c|c|}
\hline & Cerrado & Caatinga & Floresta estacional \\
\hline Tamanho & Micro II a III & Micro Il e III & Micro III, também II \\
\hline Tipo de ápice & $\begin{array}{l}\text { Arredondado, também } \\
\text { agudo }\end{array}$ & $\begin{array}{l}\text { Arredondado, } \\
\text { também atenuado }\end{array}$ & $\begin{array}{l}\text { Arredondado a } \\
\text { atenuado }\end{array}$ \\
\hline Tipo de base & Arredondada & Arredondada e aguda & $\begin{array}{l}\text { Arredondada, } \\
\text { também aguda }\end{array}$ \\
\hline Delgadeza & $1-2$, também 2-3 & 1-2 ou espalhada & $1-3$ \\
\hline Forma foliar & Eliptica & $\begin{array}{l}\text { Eliptica, também } \\
\text { oval }\end{array}$ & Eliptica e oval \\
\hline Tipo de margem & $\begin{array}{l}\text { Alto indice de margem } \\
\text { sem dentes }(73-88 \%)\end{array}$ & $\begin{array}{l}\text { Cerca de } 60 \% \text { sem } \\
\text { dentes, sendo maior } \\
\text { porcentual quando } \\
\text { em altitude }\end{array}$ & $\begin{array}{l}\text { Indice intermediário } \\
\text { de margem sem } \\
\text { dentes }(65-88 \%)\end{array}$ \\
\hline
\end{tabular}

Tabela 11 - Síntese das características físionômicas das vegetações de cerrado, caatinga e floresta estacional na Bahia.

Pode-se perceber que as diferenças são sutis, tornando dificil separar as vegetações, mas, embora os agrupamentos sejam mais complexos, eles aparentam, ainda sim, algumas similaridades. O distanciamento da assembléia fóssil de Campo Formoso na maioria das análises, parece sugerir mistura de vegetações. Assim, o desafio consiste em descobrir a estrutura vegetacional dessa associação pretérita. Maior umidade transcrita em sazonalidade com menor duração da estação seca é provavelmente um dos fatores para explicar variação da vegetação.

7.4 - Análises de vegetações e caracteristicas acrescidas do caráter altitude

Com objetivo de estabelecer relação entre características de vegetação e relevo, utilizou-se o caráter altitude nas PCAs. A presença de áreas montanhosas como a Chapada Diamantina e Serra 
do Espinhaço na porção central e sul do Estado da Bahia, altera aspectos climáticos e favorece mistura vegetacional. Os dados de altitude tiveram como base o mapa hipsométrico da SEI. O mapa fornece quatro grupos de altitude. a) altitudes menores que 400 metros correspondente à planície litorânea, alguns planaltos como pré-litorâneo e o costeiro e parte da bacia sedimentar RecôncavoTucano; b) altitudes entre 400 e 800 metros corresponde a parte do planalto sul-baiano, grande parte do chapadão ocidental do Săo Francisco e parte das denominadas depressões periféricas e interplanálticas; c) altitudes entre 800 a 1.200 metros correspondente a grande parte da Chapada Diamantina e Serra Geral do Espinhaço e d) altitudes maiores que 1.200 metros, correspondentes às porções mais elevadas da Chapada Diamantina. Nas PCAs, a altitude foi definida com menores que 400 metros, entre 400 e 800 metros e maiores que 800 metros, sendo que os municípios presentes em mais de uma classe de altitude tiveram seu score dividido entre elas.

A tabela 10 (páginas 131-134) mostra que o contato entre vegetações ocorre preferencialmente em municípios localizados em áreas de transição entre planície e planalto.

No entanto, não houve mudança significativa na PCA da vegetação de Caatinga com ou sem altitude. Em relação a PCA da vegetação estacional e regiões próximas à mesma foram observadas variações em relação ao primeiro eixo da análise, que representa mais de $20 \%$ da variação de dados.

A inclusão da altitude nas análises por características foi importante para compreensão da variação de alguns parâmetros. Por exemplo, as PCAs com tipos de dentes e tamanho foliar apresentam a mesma distribuição das "localidades", indicando que estes dois parâmetros variam em função do clima e conseqüentemente em função da altitude e as análises refletem tal relação, mas o mesmo não acontece nas PCAs com tamanho e delgadeza. Se, ao se incluir o parâmetro altitude, ocorre modificação na distribuição das "localidades", significar dizer que tamanho e delgadeza não refletem variações ambientais relacionadas à variação climática decorrente da mudança de altitude. Especificamente o parâmetro delgadeza, talvez possa ser utilizado para diferenciar tipos de estruturas vegetacionais, mas provavelmente não temperatura e umidade.

Analisando-se apenas a forma foliar, isto é, apenas os diferentes tipos de ápice e base associados à forma geral oval, elíptica e oboval, houve apenas pequenos deslocamentos nas posições das "localidades". Estas características estão classicamente relacionadas com a pluviosidade e somente parcialmente alteradas pelo relevo. 
7.5 - Análises comparativas entre diferentes tipos de vegetações

Como mencionado anteriormente, a Caatinga foi a vegetação de mais dificil caracterização O bioma em questão é mais complexo que o Cerrado, que possui gradiente bem estudado e bem definido entre o campo limpo e o cerradão. O mesmo não acontece com a Caatinga, que exibe diferentes composiçōes florísticas entre sua ocorrência sobre o cristalino ou sobre áreas sedimentares (Lemos \& Rodal, 2002), sem contar a presença do carrasco, que além de apresentar composição florística diferenciada, possui estrutura vegetacional própria (Rodal et al., 1998). Em áreas mais úmidas também ocorrem brejos de altitude, de estrutura mais fechada mas, por outro lado, com vegetação menos decídua.

A Caatinga foi comparada com diferentes tipos vegetacionais para refinamento das análises previamente comentadas. Quando comparada com vegetações úmidas, a Caatinga manteve o mesmo padrão nas diferentes PCAs, padrão que só foi relativamente alterado quando comparada com florestas estacionais. Padrão este mostrado no gráfico 7.

A PCA Caatinga e Mata Atlântica explica $44 \%$ da variação dos dados nos dois primeiros eixos. As "localidades" da Caatinga distribuem-se no segundo e terceiro quadrantes, enquanto que as "localidades" de Mata Atlântica distribuem-se no quarto quadrante. O primeiro quadrante chama a atenção por apresentar tanto "localidades" de áreas de contato ou impactadas como llhéus e Santa Cruz da Cabrália como "localidades" de Caatinga representadas por Tucano, Rodelas e Santa Terezinha.

A PCA Caatinga e Mata Ciliar explica $45 \%$ da variação dos dados nos dois primeiros eixos gerados pela análise e 59\% utilizando-se os três eixos. Como Mata Ciliar considerou-se todas as vegetaçōes ribeirinhas identificadas, mesmo tratando-se de mata de galeria ou mata de grotão. Nesta análise, o primeiro com o terceiro eixos apresentam distribuição similar ao anterior, visto que o segundo eixo representa apenas as características da assembléia fóssil de Campo Formoso. Como comentado, a distribuição das "localidades" na PCA de Caatinga e Mata Ciliar é semelhante a da análise Caatinga e Mata Atlântica, mas as localidades de Mata Ciliar encontram-se apenas no quarto quadrante (Gráfico 7). No primeiro quadrante, além de Tucano, Rodelas e Santa Terezinha encontram-se as caatingas de Maracás, Morporá, dunas de Salvador e Morro do Chapéu.

$O$ mesmo padrão de distribuição das localidades de caatinga ocorre na PCA caatinga e restinga, com a restinga no quarto quadrante. Mesmo a restinga sendo considerada um tipo vegetacional do complexo atlântico, ela exibe fisionomia própria. Esta PCA explica 40\% da variação dos dados nos dois primeiros eixos. No primeiro quadrante encontram-se todas as localidades de caatinga presentes neste quadrante na análise caatinga e mata ciliar, acrescida de 
localidades de restinga como Prado, São Sebastião do Passe, Ithéus, Santa Cruz da Cabrália, Vitória da Conquista e "Jacobina total".

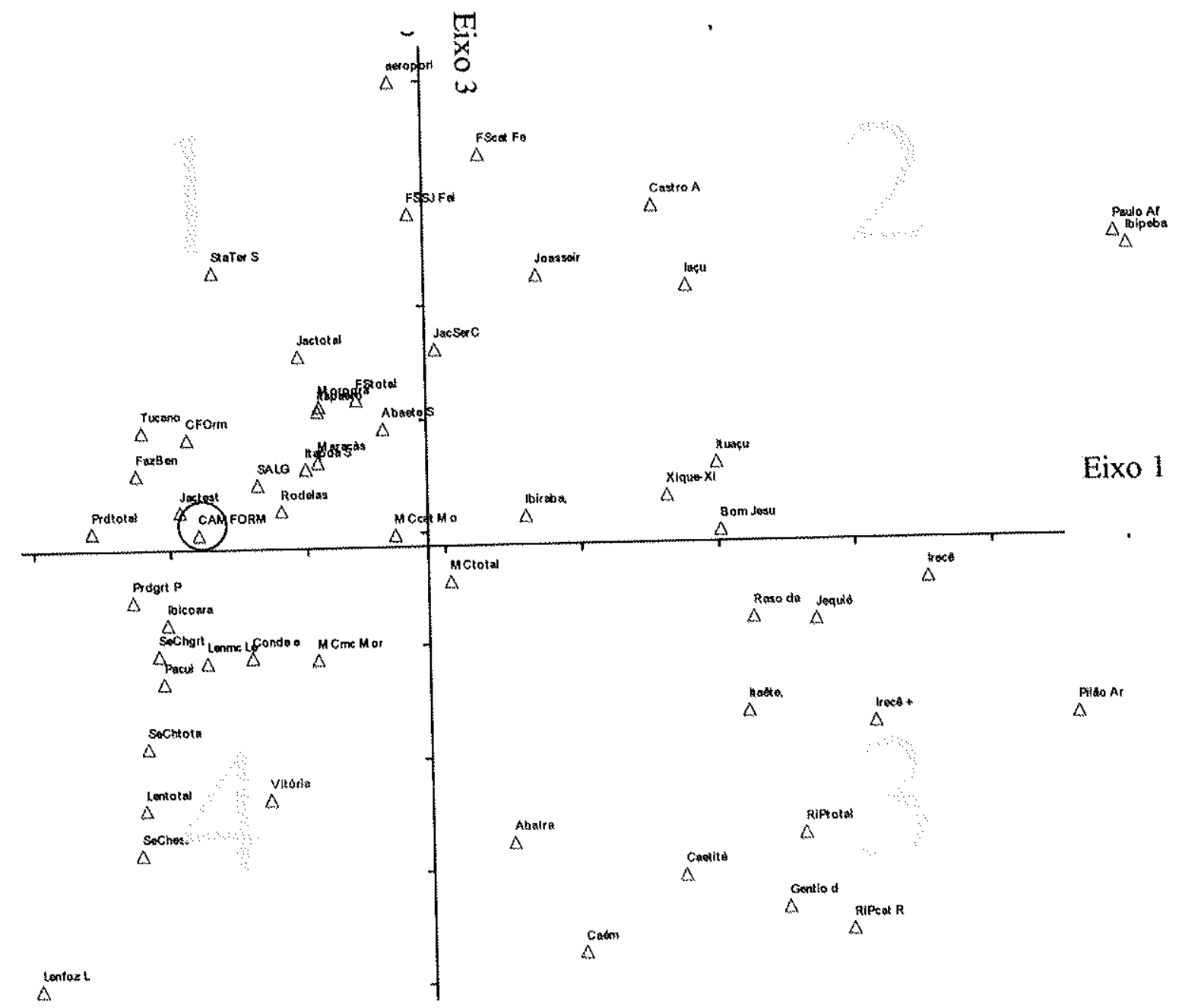

Gráfico 7 - Análise das vegetações de caatinga e mata ciliar incluindo regiões de contato. PCA de 52 "localidades" para comparaç̃o com a assembléia fóssil de Campo Formoso. Eixos 1 e 3. Abreviações na tabela 10 .

Ao se interpretar as três análises em conjunto, observa-se que não há relação de distribuição das localidades de caatinga em função da altitude, conforme já havia sido comentado nas interpretações das análises com acréscimo da altitude. $O$ segundo e terceiro quadrantes representam, nessas três análises, "localidades" com maior quantidade de folhas nas menores classes de tamanho, empiricamente observadas nas vegetações mais fechadas da caatinga. As "localidades" com maior quantidade de folhas com dentes distribuem-se no segundo quadrante e as com maior quantidade de folhas sem dentes no terceiro. A variação das "localidades" distribuídas no primeiro quadrante deve-se principalmente a diferenças relativas entre a caatinga e demais vegetações estudadas. 
De modo geral, pode-se considerar que algumas localidades de caatinga, mesmo situadas na região semi-arida, exibem caracteristicas foliares semelhantes as localidades situadas na area de ocorrência de Mata Atlânctica e restinga no litoral, onde predomina clima úmido. As caracteristicas em comuns sào as classes de tamanho maiores e sem dentes, ápice atenuado, base arredondada ou cordada e forma eliptica relativamente estreita.

Os dados de herbário são insuficientes para se saber se estas localidades são de clima mais úmido, estrutura vegetacional mais fechada (não corroborado pelos dados empíricos) ou variações na deciduocidade da vegetação.

Sugere-se que a semelhança fisionômica observada entre folhas de vegetação situadas em áreas com climas tão distintos, pode ser causada pela completa deciduocidade da vegetação de Caatinga. Esta hipótese parece ser bastante consistente, porque algumas localidades que apresentam tal fisionomia, encontram-se mais ao norte do Estado da Bahia, onde a caatinga é tipicamente decídua. Alta decidualidade exige menor adaptação fisionômica da folha, pois ela se desenvolve quase que intereiramente no periodo de chuvas e cai após o término do período úmido.

Por outro lado, localidades de caatinga situadas em áreas com estação seca mais curta, permitem que as fothas sejam mantidas na planta por tempo relevante durante a estação seca. Dessa forma, maiores adaptações são necessárias diante do crescente estresse hídrico após estação chuvosa. Por esse motivo, ao contrário da relação estabelecida no padrão internacional, folhas de vegetação mais lechadas seriam menores do observados em vegetaçồes mais abertas. A diminuição do tamanho foliar seria adaptação ao período seco e não resposta à diminuição da intensidade luminosa. Normalmente as folhas de vegetações fechadas precisam ser maiores que as folhas da mesma espécie em vegetação aberta, devido à diminuição da intensidade luminosa.

$O$ padrão de distribuição das localidades de caatinga é alterado quando as mesmas são comparadas a vegetações menos úmidas como o cerrado. A PCA caatinga e cerrado explica $41 \%$ da variação dos dados nos primeiros dois eixos da análise e pode ser observada no gráfico 8 .

Na PCA caatinga e cerrado, as "localidades" de caatinga, até então distribuídas nos segundos e terceirtos quadrantes, passa a ocupar o primeiro e segundo quadrante, mesmo a formação dos eixos sendo similar aos eixos formados pelas PCAs de Caatinga e Mata Ciliar. $O$ cerrado e "localidades" com contato entre as vegetações distribuem-se no terceiro quadrante, como Abaíra e Caetité, juntamente com duas "localidades" de contato entre caatinga e floresta estacional, Caém e Gentio do Ouro. Mas outras "localidades" de contato entre caatinga e floresta estacional como Bom Jesus da Lapa, Ituaçu e Castro Alves, distribuem-se entre o primeiro e segundo quadrantes. Ao primeiro quadrante soma se o município de formosa, região de cerrado. $O$ quarto quadrante é quase restrito a assembléia fóssil de Campo Formoso. É interessante notar que as 
"localidades" presentes no primeiro quadrante quase não são alteradas em relação às PCAs anteriores e que "localidades" que não correspondem a áreas de contato, "migraram" do terceiro quadrante para o segundo, com a "chegada" da vegetação de cerrado, tornando o quarto quadrante restrito a assembléia fóssil.

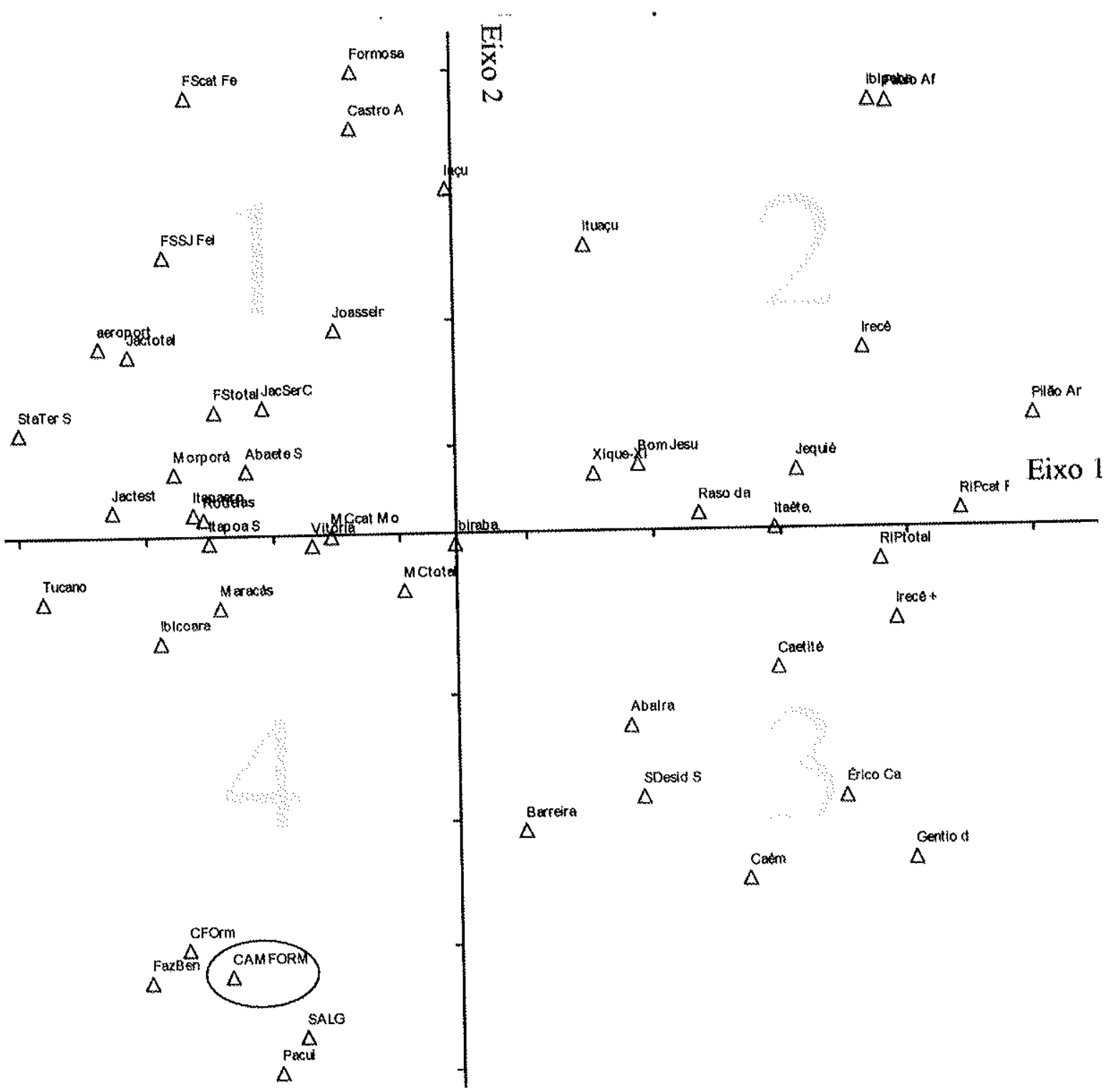

Gráfico 8 - Análise das vegetações de caatinga e cerrado incluindo áreas de contato. PCA de 46 "localidades" em comparação com a assembléia fóssil de Campo Formoso. Eixos 1 e 2. Abreviações na tabela 10.

Pode-se concluir, portanto, que o segundo e o terceiro quadrantes representam vegetações sujeitas a condições sazonais. A localidade Formosa, mais ao norte, poderia corresponder a vegetação de cerrado de caráter mais decíduo, aproximando-se das adaptações presentes na vegetação de caatinga. Neste caso, as condições sazonais não correspondem a condições extremas, 
na qual o periodo seco não é tão intenso quanto o periodo árido existente em boa parte da distribuição da caatinga

Para testar essa hipótese, analisa-se a PCA caatinga e vegetações estacionais conjuntamente. A análise não consegue dî́renciar bem as duas vegetações, embora o segundo quadrante registre apenas caatinga e o terceiro quadrante registre localidades em áreas de contato entre vegetações. $\mathrm{O}$ primeiro quadrante mantem-se similar ao primeiro quadrante da PCA caatinga e mata ciliar, acrescido das localidades com presença de floresta estacional como Pindubaçu, Itaberaba, Ituberá e Wagner. No quarto quadrante encontra-se a assembléia fóssil, localidades com floresta estacional e em áreas de contato.

7.6 - Interpretação geral da assembléia fóssil de Campo Formoso com base nas diferentes análises realizadas

A análise fisionômica se constitui em ferramenta de grande valia nas interpretações de assembléias fósseis por permitir inferir a estrutura vegetacional correspondente a parâmetros como dossel aberto ou fechado ou vegetação com apenas um dossel, dois dosséis ou multiestratificada. Em alguns casos, é possível inferir conjuntamente temperatura e umidade, principalmente em vegetações subtropicais ou temperadas. Desde Wolfe (1993), sabe-se que a temperatura só pode ser inferida para regiões de temperatura média até $28^{\circ} \mathrm{C}$.

Os resultados obtidos indicam que a fisionomia das folhas não é um bom indicador de biomas como um todo, mas permite boas indicações estruturais, que de certa forma refletem condições climáticas. A primeira conclusão importante decorrente desta análise refere-se ao entendimento das características fisionômicas da vegetação de Caatinga. A análise fisionômica da vegetação da Bahia foi norteada pela observação empírica da não concordância da vegetação de caatinga aos padrões internacionais estabelecidos por Wolfe (1993). Não é comum a presença de vegetação decídua em áreas tropicais e a decidualidade da caatinga pode mascarar a deficiência hídrica, porque suas folhas estão adaptadas para os períodos mais favoráveis.

Ao se estabelecer esta condição fundamental, torna-se mais clara a interpretação das demais características. Os estudos de cada vegetação separadamente e de cada tipo de característica, permitiram a interpretação dos demais parâmetros, corroborados pelas análises comparativas entre duas vegetações e pelas análises de características incluindo o parâmetro altitude. 
Considerando tais análises, pode-se interpretar que a fisionomia da assembléia fóssil assemelha-se a vegetações presentes em maiores altitudes que a presente em Campo formoso atualmente, conforme sugere a PCA de caatinga acrescida por caráter altitude. Estando hoje em área de ocorrência de caatinga, vegetação decídua, a assembléia fóssil estaria sujeita a condições sazonalmente mais úmidas, como as florestas estacionais semideciduas. Esta conclusão pode ser corroborada pela análise das características dentes e tamanho, na qual a assembléia fóssil encontrase próximas a vegetações na Chapada Diamantina e a vegetações de dossel fechado.

Em relação ao tamanho foliar e delgadeza da mesma, embora as PCAs com ou sem altitude sejam muito diferentes, em ambas a assembléia fóssil de Campo Formoso é relativamente afastada das outras "localidades". Como a situação pretérita possa ter sido diferente da atual, deve-se considerar a possibilidade de melhores chances de preservação fossilifera de folhas com determinada delgadeza, visto que, aparentemente, este é um dos principais parâmetros afetados sem equivalente vegetacional atual. Por outro lado, quando se considera apenas o posicionamento em relação a um eixo, verifica-se a proximidade com "localidades" com diferentes tipos vegetacionais, o que poderia sugerir mistura vegetacional, conforme já discutido pela análise florística.

A tabela 12 sintetiza todas as cidades associadas à assembléia fóssil de Campo Formoso, em relação a cada eixo analisado nas diferentes PCAs. Como nem sempre a proximidade de um eixo representa grandes concordâncias, a tabela mostra em negrito, a análise na qual a cidade em questão está associada a Campo Formoso em dois eixos, representando maior proximidade à assembléia fóssil na PCA em questão. As discussões são apresentadas após a tabela.

\begin{tabular}{|c|c|}
\hline Cidades nos gráficos de PCA & Próximas a Campo Formoso em pelo menos três diferentes eixos \\
\hline Abaira & 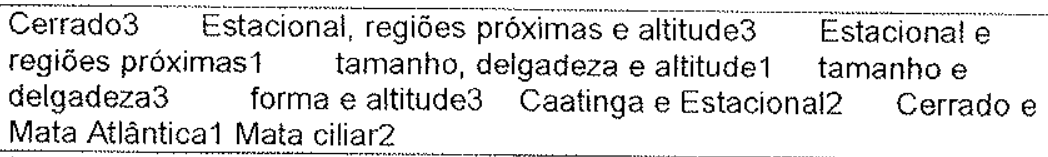 \\
\hline Alagoinhas & $\begin{array}{l}\text { Estacional e regiöes próximas } 3 \text { tamanho, delgadeza e altitude1 } \\
\text { Cerrado, estacional e campo rupestre1 } \quad \text { Caatinga e Estacional } 2\end{array}$ \\
\hline Amelia Rodrigues & $\begin{array}{l}\text { tamanho, delgadeza e altitude } 1 \text { tamanho e delgadeza } 1 \text { e } 3 \\
\text { formae altitude } 1\end{array}$ \\
\hline Andaraí & $\begin{array}{l}\text { Estacional e regióes próximas } 3 \text { Caatinga e Estacional1 Caatinga e } \\
\text { Estacional2 Mata ciliar e campo rupestre } 3\end{array}$ \\
\hline Barreiras & $\begin{array}{l}\text { Cerrado2 forma e altitude1 dentes, tamanho e altitude2 } \\
\text { dente e tamanho2 Cerrado, Estacional e Campo rupestre1 }\end{array}$ \\
\hline Belmonte & $\begin{array}{l}\text { Restinga2 tamanho e delgadeza3 Caatinga e Restinga2 } \\
\text { Cerrado e Mata Atlântica3 }\end{array}$ \\
\hline Boa Vista do Tupim & $\begin{array}{l}\text { Estacional e regiöes de contato } 2 \text { dente e tamanho2 dente altitude } \\
\text { Caatinga e Estacional1 }\end{array}$ \\
\hline Bom Jesus da Lapa & $\begin{array}{l}\text { Caatinga3 Caatingae altitude } 3 \text { Estacional e regiöes próximas1 } \\
\text { forma e altitude } 1 \quad \text { dentes e altitude2 e } 3 \text { dentes e tamanho2 } \\
\text { Caatinga e Mata ciliar3 } \quad \text { Caatinga e Restinga2 }\end{array}$ \\
\hline Caem & $\begin{array}{l}\text { Estacional, regiões próximase altitude } 3 \text { Estacional e regiöes } \\
\text { próximas } 1 \text { Caatinga e Campo rupestre2 }\end{array}$ \\
\hline Caetité & $\begin{array}{l}\text { Cerrado3 Estacional, regiöes próximas e altitude3 Estacional e } \\
\text { regiöes proximas1 tamanho e delgadeza3 forma e altitude1 } \\
\text { Caatinga e Estacional2 Cerrado e Mata Attântica1 e } 3\end{array}$ \\
\hline
\end{tabular}

Tabela 12 - "Localidades" próximas a Campo Formoso em pelo menos três eixos das diferentes PCAs realizadas 


\begin{tabular}{|c|c|}
\hline Cairu & $\begin{array}{l}\text { Restinga2 tamanho e delgadeza3 dentes e tamanho2 Caatinga } \\
\text { e Restinga1 }\end{array}$ \\
\hline Caravelas & $\begin{array}{l}\text { Mata Atlantica3 Mata Atlantica2 dentes e altitude1 e } 3 \text { dentes } \\
\text { e tamanho1 Cerrado e Mata Atlantica3 }\end{array}$ \\
\hline Castro Alves & Caatinga 3 Caatinga e altitude 3 Cerrado, estacional e campo rupestre 3 \\
\hline Conde e vegetaçóes & $\begin{array}{l}\text { Estacional, regiōes próximase aititude } 3 \text { Caatinga e Restinga1 e } 2 \\
\text { Mata ciliar e campo rupestre } 3\end{array}$ \\
\hline Entre Rios & $\begin{array}{l}\text { Restinga2 tamanho e delgadeza1 forma e altitude } 3 \\
\text { estacional e campo rupestre1 Caatinga e Mata Atântica }\end{array}$ \\
\hline Érico Cardoso & $\begin{array}{l}\text { Estacional, regiôes próximas e altitude } 3 \quad \text { Estacional e regióes } \\
\text { próximas } 1 \text { Caatinga e Estacional2 Cerrado e Mata Atlântica1 e } 3\end{array}$ \\
\hline Espianada & $\begin{array}{l}\text { Estacional e regióes de contato3 Estacional, regiões próximas e } \\
\text { altitude3 Restinga2 Caatinga e Restinga2 }\end{array}$ \\
\hline Feira de Santana, caatinga & $\begin{array}{l}\text { Caatinga3 Catinga e altifude3 Caatinga e Cerrado1 Caatinga e } \\
\text { Estacional1 }\end{array}$ \\
\hline $\begin{array}{l}\text { Feira de Santana, Serra de São } \\
\text { José }\end{array}$ & 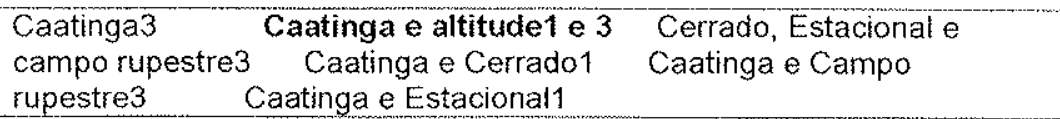 \\
\hline Feira de Santana total & $\begin{array}{l}\text { Estacional e regióes próximas } 3 \text { tamanho e delgadeza1 Caatinga e } \\
\text { Cerrado1 Caatinga e Estacional1 Caatinga e Mata ciliar3 }\end{array}$ \\
\hline Formosa do Rio Preto & tamanho, delgadeza e altitude 1 tamanho e delgadeza 1 e 3 \\
\hline Gentio do Ouro & $\begin{array}{l}\text { Estacional, regiões próximas e altitude3 Estacional, regiões } \\
\text { próximas } 3 \text { tamanho e delgadeza2 forma e altitude } 1 \text { e } 3 \text { dentes } \\
\text { e tamanho3 Caatinga e campo rupestre } 2 \text { Caatinga e Estacional2 }\end{array}$ \\
\hline laçu & $\begin{array}{l}\text { Caatinga3 Caatinga e altitude3 tamanho, delgadeza e aititude } 1 \\
\text { tamanho e delgadeza3 }\end{array}$ \\
\hline lbicoara & 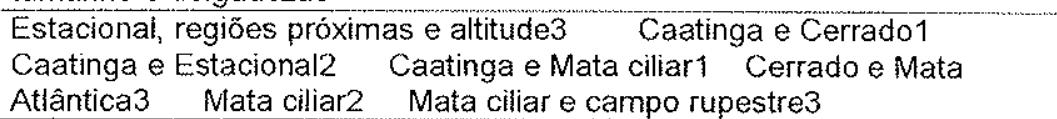 \\
\hline Ibiraba & $\begin{array}{l}\text { Caatinga3 Caatinga e altitude } 3 \text { tamanho e delgadeza3 dentes, } \\
\text { tamanhos e altitude2 dentes e tamanho2 Caatinga e Mata ciliar3 } \\
\text { Caatinga e Restinga2 }\end{array}$ \\
\hline Ihéus, restinga & $\begin{array}{l}\text { forma altitude } 3 \text { dentes, tamanho e altitude } 1 \text { dentes e tamanho } 1 \\
\text { Caatinga e Restinga2 }\end{array}$ \\
\hline Irecê & $\begin{array}{l}\text { Caatinga3 Caatinga e altitude } 3 \text { forma e altitude } 1 \text { e } 3 \text { dentes, } \\
\text { tamanho e altitude2 Caatinga e Estacional2 Caatinga e Restinga2 }\end{array}$ \\
\hline Itaberaba & $\begin{array}{l}\text { Estacional e regiöes próximas3 tamanho, delgadeza e altitude1 } \\
\text { tamanho e delgadeza1 forma e altitude } 3 \text { Caatinga e Estacional1 }\end{array}$ \\
\hline Itacaré & Restinga2 Caatinga e Mata Attântica Caatinga e Restinga1 \\
\hline Itaête & $\begin{array}{l}\text { Estacional, regióes próximas e altitude3 Estacional e regiöes } \\
\text { próximas } 1 \text { e } 3 \text { tamanho, delgadeza e altitude1 forma e altitude1 e } 3 \\
\text { dentes, tamanho e altitude2 dentes e tamanho2 } \\
\text { Estacional2 }\end{array}$ \\
\hline Ituaçu & $\begin{array}{l}\text { Caatinga3 Estacional e regióes próximas } 3 \text { tamanho, delgadeza e } \\
\text { altitude1 tamanho e delgadeza1 forma e altitude3 Caatinga e } \\
\text { mata ciliar3 Caatinga e Restinga2 }\end{array}$ \\
\hline ituberá & $\begin{array}{l}\text { Estacional, regiöes próximas e altitude3 } \\
\text { próximas } 3 \text { tamanho e delgadezacional e regiões } \\
\text { dentes e tamanho3 }\end{array}$ \\
\hline Jacobina, estacionais & $\begin{array}{l}\text { Caatinga1 Caatinga e altitude1 Estacional e regiöes de contato3 } \\
\text { Estacional, regiöes próximas e altitude3 Estacional e regiőes próximas3 } \\
\text { forma e altitude3 Caatinga e campo rupestre1 Caatinga e Restinga2 } \\
\text { Caatinga e Mata ciliar1 e } 3\end{array}$ \\
\hline Jacobina, Serra do Cruzeiro & Caatinga e Cerrado1 Caatinga e Estacional 1 Campo rupestre2 \\
\hline Jacobina, total & $\begin{array}{l}\text { Caatinga1 Caatinga e altitude1 Estacional e regiôes próximas3 } \\
\text { tamanho e delgadeza3 forma e altitude3 Caatinga e campo } \\
\text { rupestre1 Caatinga e Mata Atlântica Caatinga e Restinga1 }\end{array}$ \\
\hline Jequié & $\begin{array}{l}\text { Caatinga } 3 \text { Caatinga e altitude } 3 \text { Estacional e regióes próximas } 1 \text { e } 3 \\
\text { forma e altitude } 1 \text { dentes, tamanho e altitude } 2 \text { dentes e tamanho3 } \\
\text { dentes e altitude }\end{array}$ \\
\hline Joazeiro & Caatinga3 Caatinga e altitude 3 tamanho, delgadeza e altitude 1 \\
\hline Jussari & Estacional, regiões próximas e altitude 3 Caatinga e Estacional2 \\
\hline Lençóis, mata ciliar & Caatinga e Mata ciliar1 Mata ciliar2 Mata ciliar e campo rupestre 3 \\
\hline Lençóis, mata de grotäo & Caatinga e Mata ciliar1 Mata ciliar2 e 3 Mata ciliar e campo rupestre 3 \\
\hline $\begin{array}{l}\text { Lençós, Serra da Chapadinha } \\
\text { total }\end{array}$ & $\begin{array}{l}\text { tamanho e delgadeza3 Caatinga e campo rupestre1 Caatinga e mata } \\
\text { ciliar } \quad \text { Mata ciliar2 e } 3\end{array}$ \\
\hline Lencoís, Lençois total & tamanho e delgadeza3 Caatinga \\
\hline
\end{tabular}

Tabela 12 (cont.) - "Localidades" próximas a Campo Formoso em pelo menos três eixos das diferentes PCAs realizadas 


\begin{tabular}{|c|c|}
\hline & $\begin{array}{l}\text { e campo rupestre1 Caatinga e Estacional2 Caatinga e Mata ciliar1 } \\
\text { Mata ciliar2 e } 3\end{array}$ \\
\hline Lencóis, fechado & tamanho e delgadeza3 dentes, tamanho e altitude 1 dentes e tamanho 1 \\
\hline Maracás & $\begin{array}{l}\text { Caatinga1 Caatinga e altitude1 Caatinga e Cerrado1 Caatinga e } \\
\text { campo rupestre1 Caatinga e Estacional } 1 \text { Caatinga e Mata Atiântica } \\
\text { Caatinga e Mata ciliar3 } \quad \text { Caatinga e Restinga1 e } 2\end{array}$ \\
\hline Mata de São João & $\begin{array}{l}\text { Mata Atlântica3 tamanho e delgadeza1 forma e altitude } 3 \text { dentes } \\
\text { e tamanho2 Caatinga e Mata Atlântica Cerrado e Mata Atlântica3 }\end{array}$ \\
\hline Miguel Caimon total & tamanho, delgadeza e altitude 1 tamanho e delgadeza1 e 3 \\
\hline Morporá & $\begin{array}{l}\text { Caatinga1 Caatinga e altitude1 Cerrado3 Estacional e regiós } \\
\text { próximas3 Caatinga e Cerrado1 Caatinga e campo rupestre1 } \\
\text { Caatinga e Estacional1 Caatinga e Mata Atlântica Caatinga e mata } \\
\text { ciliar3 Caatinga e Restinga1 }\end{array}$ \\
\hline MC, campo rupestre & $\begin{array}{l}\text { tamanho e delgadeza3 dentes, tamanho e attitude2 Cerrado, } \\
\text { Estacional e campo rupestre } 1 \quad \text { Mata ciliar e campo rupestre } 3\end{array}$ \\
\hline MC, caatinga & $\begin{array}{l}\text { tamanho e delgadeza1 e } 3 \text { Caatinga e Estacional1 Caatinga e } \\
\text { Mata Atlântica Caatinga e Mata ciliar3 Caatinga e Restinga2 }\end{array}$ \\
\hline MC, total & $\begin{array}{l}\text { Estacional, regiões próximas e altitude } 3 \text { Estacional e regióes } \\
\text { próximas } 3 \text { tamanho, delgadeza e altitude } 1 \text { tamanho e delgadeza3 } \\
\text { dentes e tamanho2 } \\
\text { Campo rupestre3 }\end{array}$ \\
\hline Mucug, campo rupestre & $\begin{array}{l}\text { tamanho, delgadeza e altitude1 tamanho e delgadeza } 1 \text { e } 3 \\
\text { dentes e tamanho } \quad \text { Cerrado, Estacional e campo rupestre } 1\end{array}$ \\
\hline Mucugê, total & $\begin{array}{l}\text { tamanho e dclgadeza1 e } 3 \text { Cerrado, Estacional e campo rupestre1 } \\
\text { Campo rupestre } 3\end{array}$ \\
\hline Pindubaçu & $\begin{array}{l}\text { tamanho, delgadeza e altitude1 tamanho e delgadeza1 Caatinga e } \\
\text { Estacional1 }\end{array}$ \\
\hline Prado, mata de grotão & $\begin{array}{l}\text { Mata Atiântica3 Caatinga e Mata ciliar1 Cerrrado e Mata Atiânatica3 } \\
\text { Mata ciliar2 Mata ciliar e Campo rupestre3 }\end{array}$ \\
\hline Prado, Prado, restinga & $\begin{array}{ll}\text { Restinga2 } & \text { tamanho, delgadeza e altitude2 tamanho e } \\
\text { delgadeza3 } & \text { forma e altitude3 dentes, tamanho e altitude } 3\end{array}$ \\
\hline Prado, Prado total & $\begin{array}{l}\text { Mata Atlântica3 tamanho e delgadeza3 dentes, tamanho e altitude1 } \\
\text { dentes e tamanho1 Caatinga e Mata ciliar } 3 \text { Cerrado e Mata Allantica3 } \\
\text { Mata ciliar2 Mata ciliar e Campo rupestre } 2 \text { e } 3\end{array}$ \\
\hline Raso da Catarina & $\begin{array}{l}\text { Caatinga } 3 \text { Caatinga e altitude } 3 \text { tamanho e delgadeza } 3 \text { dentes, } \\
\text { tamanho e altitude3 }\end{array}$ \\
\hline Ribeira P, ecótono & $\begin{array}{l}\text { Estacional, regiões próximas e altitude } 3 \text { Estacional e regiôes } \\
\text { próximas } 1 \text { Caatinga e Estacional2 }\end{array}$ \\
\hline Ribeira do Pombal total & $\begin{array}{l}\text { Estacional, regiôes próximase aititude } 3 \text { Estacional e regiöes próximas } 1 \\
\text { dentes, tamanho e altitude2 dentes e altitude Caatinga e Estacional } 2\end{array}$ \\
\hline Rodelas & $\begin{array}{l}\text { Caatinga1 Caatinga e aititude } 1 \text { Caatinga e Cerrado1 Caatinga e } \\
\text { campo rupestre1 Caatinga e Estacional } 1 \text { Caatinga e Mata Atlântica } \\
\text { Caatinga e Mata ciliar3 Caatinga e Restinga1 e } 2\end{array}$ \\
\hline dunas do Abaeté & $\begin{array}{l}\text { Caatinga3 Caatinga e altitude } 3 \text { tamanho e delgadeza1 } \\
\text { Caatinga e Cerrado1 Caatinga e Estacional Caatinga e Mata ciliar3 }\end{array}$ \\
\hline dunas do aeroporto & $\begin{array}{l}\text { Caatinga1 Caatinga e altitudet Caatinga e Cerrado3 Caatinga e } \\
\text { campo rupestre1 Caatinga e Estacional1 }\end{array}$ \\
\hline dunas de ltapöa & $\begin{array}{l}\text { Caatinga e altitude1 e } 3 \text { forma e altitude3 Caatinga e Cerrado1 } \\
\text { Caatinga e Campo rupestre1 Caatinga e Estacional1 Caatinga e Mata } \\
\text { Atlântica Caatinga e Mata ciliar3 Caatinga e Restinga1 }\end{array}$ \\
\hline SCC, total & 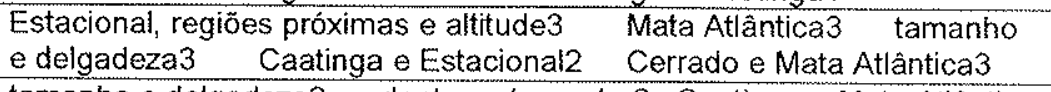 \\
\hline SSP, total & tamanho e delgadeza3 dentes e tamanho3 Caatinga e Mata Atlântica \\
\hline Tucano & Caatinga e Mata ciliar1 e 3 Caatinga e Restinga2 \\
\hline Urucuca & forma e altitude 3 dentes, tamanho e altitude 1 e 3 dentes e tamanho 1 \\
\hline Wagner & $\begin{array}{l}\text { Estacional, regiōes próximas e altitude3 Estacional e regiões } \\
\text { próximas3 tamanho, delgadeza e altitude1 tamanho e } \\
\text { delgadeza1 Caatinga e Estacional1 }\end{array}$ \\
\hline Xique-Xique & 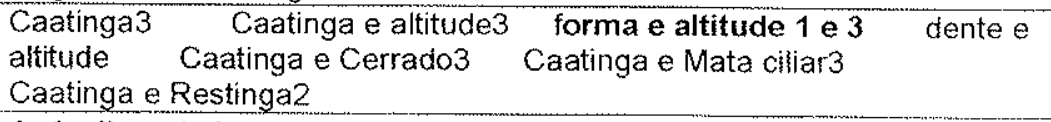 \\
\hline
\end{tabular}

Tabela 12 (cont.) - "Localidades" próximas a Campo Formoso em pelo menos três eixos das diferentes PCAs realizadas 
Analisando-se as "localidades" que se encontram mais freqüentemente associadas a assembléia fóssil de Campo Formoso, verifica-se que quase todas as "localidades" associam-se em, pelo menos, um eixo estabelecido pelas diferentes análises. Entretanto, tendo, em vista ao grande número de análises realizadas, procurou-se observar quais "localidades" estão associadas em maior número de análises possivel. Dezenove "localidades" estão associadas em pelo menos 7 eixos diferentes. O primeiro ponto interessante corresponde ao fato de que não há correlação entre a quantidade de eixos com a ocorrência de associação entre dois eixos de uma mesma análise. Das 19 "localidades" anteriormente comentada, 4 delas não estão associadas em dois eixos de uma mesma análise, sendo que "Jacobina estacional" e "Morporá" chegam a apresentar similaridades em mais de 10 eixos, conforme indica a tabela 12.

Das 15 "localidades" restantes, 4 estão associadas em dois eixos da mesma análise de características, sendo "Xique-Xique", "Irecê" e "Gentio do Ouro" próximas na PCA de forma relacionada a altitude e "Bom Jesus da Lapa" na PCA de dentes relacionados a altitude. "Prado total" associa-se na PCA de mata ciliar com campo rupestre, "Lençóis total" na PCA de mata ciliar, "Rodelas" e "Maracás" na PCA caatinga e restinga, assim como a localidade "dunas de Itapoá e aeroporto, Salvador", que também está associada a assembléia fóssil na PCA caatinga e altitude, juntamente com "Serra de São José, Feira de Santana". "Morro do Chapéu total" associa-se na PCA caatinga e floresta estacional, enquanto "Itaête" e "Jequiè" estão associadas na PCA floresta estacional e proximidades. "Itaête" também associa-se na PCA forma e altitude. Finalizando, "Caetité" encontra-se associada na PCA cerrado e Mata Atlântica.

O mais importante desses agrupamentos é que a maioria das "localidades" corresponde a áreas de transição entre vegetações, geralmente com a presença de caatinga ou correspondem a vegetação de caatinga, exceto "Lençóis total" e "Prado total".

Outras localidades associam-se poucas vezes a assembléia fóssil de Campo Formoso, mas estão próximas em dois eixos de uma mesma análise. Entre as "localidades" associadas em análises de características, encontra-se "Amélia Rodrigues", "Porto Castro Alves, Cachoeira", "Formosa do Rio Preto", "Miguel Calmon total", "Morro do Chapéu, caatinga", "Mucugê, campo rupestre" e "Mucugê total" na PCA tamanho e delgadeza e "Caravelas" na PCA dentes, tamanho e altitude. Estas "localidades" representam diversas vegetações, sendo de difícil interpretação.

Entre as "localidades" associadas em análises por vegetação, encontra-se "Andarai" e "Castro Alves" na PCA caatinga e estacional, sendo interessante notar que ambas representam áreas de contato entre a vegetação de caatinga e de floresta estacional; "Conde e vegetações" na PCA caatinga e restinga, localidade que inclui vegetações de floresta estacional, cerrado e mata ciliar; 
"Tucano" na PCA caatinga e mata ciliar representando vegetaçăo de caatinga e "Érico Cardoso" na PCA cerrado e Mata Allântica representando vegetação de cenado.

"Caravelas", "Ilhéus, mata ombrófila", "Ilhéus, Mata da Esperança", "Ilhéus, mata de cambruca", "Ilhéus, Olivença" e "Santa Cruz da Cabrádia" na PCA de Mata Atlântica, e "Serra da Chapadinha, Lençóis" na PCA mata ciliar năo representam associações tão representativas por estarem em análises de apenas uma vegetação, indicando apenas que são as "localidades" mais similares à assembléia fóssil que as demais.

A assembléia fóssil de Campo Formoso encontra-se mais próxima a floresta estacional e regiōes de contato entre a floresta estacional e caatinga, mas exibe fisionomia similar à Mata Atlântica. Quando comparada à vegetação de cerrado, a assembléia fóssil situa-se praticamente isolada, porém mais próxima do cerrado por se distribuir no quarto quadrante e não no primeiro, similarmente ao que ocorre quando a caatinga é comparada com a vegetação de campo rupestre, de fato um tipo especial de cerrado.

Pode-se concluir, portanto, que em termos fisionômicos, a assembléta fóssil de Campo Formoso representaria floresta de dossel fechado (como a vegetação atlântica) com características estacionais intermediárias à Caatinga e à Floresta Estacional Semidecidual. 


\section{8 - Discussǒes gerais}

\section{1 - Discussão das informações obtidas pelo estudo dos tufos calcários}

Analisando-se os depósitos fossiliferos ocorrentes nas proximidades de Campo Formoso depara-se, de imediato, com o tipo de deposição, característico de ambiente com água em abundância. Os depósitos hoje se encontram parcialmente erodidos, sugestivo de deposição em ambiente chuvoso e/ou fluvial seguido de erosão.

Comparando-se o tipo de depósito com outros já descritos, observa-se que os mecanismos de deposição dos tufos calcários no Brasil não correspondem aos descritos para a Europa, embora sejam mais semelhantes aos tufos porosos porém duros, de acordo com a classificação de Jassen $e t$ al. (1999).

Entretanto, o que a assembléia fóssil foi capaz de dizer sobre esse tempo de abundância de água em pleno sertão baiano ? Inicialmente, obtiveram-se informações tafonômicas do depósito fossilifero, reconheceu-se os morfotipos presentes na assembléia fóssil e por fim, interpretou-se os aspectos fisionômicos das folhas presentes, até mesmo daquelas que não puderam ser identificadas taxonomicamente.

$\mathrm{Na}$ interpretação tafonômica, o estudo iniciou-se pela análise dos fósseis em si, ampliandose as análises para as feições sedimentológicas do depósito, conforme apresentado no capitulo 5 . Foi importante reconhecer o grau de transporte sofrido pelos espécimes fósseis para estimar a possibilidade de mistura de diferentes associações florísticas ou mesmo se os espécimes estariam ocorrendo em áreas com diferentes aspectos ambientais. A distribuição por classe de tamanhos das tafofloras nos três afloramentos estudados corresponde à distribuição segundo curva normal com tendência de classes de tamanhos maiores, indicando que o transporte aparentemente não interferiu na preservação das folhas. As frequêencias de folhas com aparência tauterizada nos três afloramentos são pequenas, mesmo com variações entre os diferentes pontos amostrados. Desse modo, o tempo de suas permanências em ambiente subaéreo teria sido pequeno ou mesmo inexistente a grande maioria das folhas teria alcançado diretamente um corpo aquoso.

O ambiente geral de deposição, baseando-se apenas nas folhas, poderia ter sido de corpo aquoso de baixa energia, contudo, como a deposição de tufos calcários ocorre em ambiente de águas agitadas, a boa preservação pode ser atribuída ao pequeno transporte.

Associando-se caracteristicas sedimentológicas às folhas propriamente ditas, foram observados canais de escoamento e canalículos, estando os últimos sob folhas ou não. As folhas distribuem-se aleatoriamente, normalmente em vários planos distintos, com diferentes tipos de 
preservação, sem contudo, fornecer dados sobre o sub-ambiente deposicional. Grandes espaços vazios normalmente estão presentes sem qualquer relação com as folhas, enquanto que a deposição de carbonato ocorre intimamente associada às folhas, eventualmente com pequena quantidade de sedimento agregado ao depósito.

Algumas características, quando analisadas em conjunto, permitiram o reconhecimento dos sub-ambientes deposicionais, principalmente através das comparações eletuadas nos depósitos atuais nas proximidades de Bonito, MS. Locais com fluxo de alta turbulência, precipitam o carbonato lentamente, formando camadas mais compactas e finamente laminadas. A deposição similar a fibras de aragonita ocorre principalmente no afloramento Salgadinho e requer associação de outras características tafonômicas para obter-se reconhecimento de sub-ambiente deposicional.

Nos afloramentos de Campo Formoso, percebeu-se aumento no porcentual de degradação microbiológica, compativel com o aumento da temperatura. Diferenças neste porcentual de degradação nos afloramentos de idades mais recentes, puderam ser utilizadas para definir diferentes sub-ambientes de deposição.

Conforme salientado anteriormente, estes padrões foram estabelecidos neste trabalho, visto que não há estudos sobre a deposição de tufos calcários semelhantes em ocorrências brasileiras entre as publicações pesquisadas. Os depósitos brasileiros atuais estudados referem-se aos da região de Bonito, MS, utilizados para comparação.

Em pontos específicos dos afloramentos de Campo Formoso, a calcita é mais porosa, a rocha é proporcionalmente mais clara e as folhas possuem menos contrastes. Além das dicotiledôneas, ocorrem também monocotiledôneas, a maioria das folhas como impressões. As paredes dos canais de escoamento e canalículos são finas ou grossas, mas sempre com uma luz relativamente ampla. Variações destas características nas amostras, sugerem depósitos em condições variáveis sazonalmente ou temporalmente.

8.2 - Discussão das informações obtidas pelo estudo taxonômico dos macrofitofósseis

Foram descritos 69 morfotipos, sendo identificados 49 morfotipos, 44 a nível de espécie, distribuídos em 37 gêneros e 26 famílias, todos com distribuição tropical, com exceção de Rhamnaceae, embora Zizyphus joazeiro seja típica da região de caatinga. A assembléia pode ser considerada bastante diversificada. O porcentual e a confiabilidade de identificação foram considerados altos, com identificações de espécies pouco preservadas, auxiliadas por estudo em herbário próximo a área de estudo. Estudos complementares no herbário SPF, com registro de 
plantas de cerrado de Minas Gerais e de espécies da Bahia foram realizados. Os espécimes baianos foram privilegiados no processo de comparaçăo.

Ao se analisar a distribuição das espécies nos diferentes sub-ambientes deposicionais fósseis descritos na análise tafonômica, observa-se que as espécies não são as mesmas em cada subambiente, mas tanto no sub-ambiente de alta turbulència quanto o sub-ambiente com precipitação mais rápida de carbonato a familia Annonaceae é uma das mais diversificadas. Por outro lado, a distribuição das espécies mostram a tendência de manter a mesma estrutura da associação total. Também não há alterações em relação ao habitat preferencial das espécies presentes. Embora o afloramento Salgadinho aparente ter menos espécies de caatinga, ele contem Zizyphus jocazeiro. Não há, portanto, grandes variações de vegetação nos diferentes sub-ambientes, que poderiam indicar mudanças vegetacionais ao longo de mudanças climáticas durante a deposição dos tufos calcários. Aparentemente, os sub-ambientes deposicionais refletem apenas a quantidade e o tipo do fluxo d'água, conforme esperado.

Mesclando-se dados obtidos pelos espécimes utilizados na identificação do morfotipo, registro da distribuição das espécies documentadas no ALCB e dados de literatura, pode-se constatar a ocorrência de mistura vegetacional, com espécies de ampla distribuição geográfica e espécies típicas da caatinga e cerrado, que teriam avançado vindo de oeste. A mistura vegetacional ainda sugere que possa ter havido migração de elementos das florestas estacionais presentes na encosta da Chapada Diamantina, principalmente aquelas que preferem ambientes úmidos. A melhor distribuição das chuvas é compatível com as migrações.

Sete espécies descritas são consideradas de cerrados, sete são consideradas elementos das florestas estacionais e três da vegetação de caatinga, muito embora o número de gêneros presentes sejam bem freqüentes nesta última. Entres as espécies de cerrado mais características estão Annona coriacea e A. crassiflora (Annonaceae) e entre os elementos das florestas estacionais encontrammse quatro espécies de Euphorbiacae, além de Luehea grandiflora (Tiliaceae), Prumus sellowii (Rosaceae) e Rollinia sylvatica (Annonaceae). Zizyphus joazeiro (Rhamnaceae) caracteriza a presença de caatinga, mesmo que seja descrito como espécie de habitats mais úmidos ou mais disturbados (Pereira et al., 2003; Rodal \& Nascimento, 2002).

Analisando-se de acordo com a diversidade de cada família, as florestas estacionais normalmente exibem as famílias Euphorbiaceae, Leguminosae, Myrtaceae e Rubiaceae entre as mais diversificadas, a vegetação de caatinga também contem Euphorbiaceae, Leguminosae e Myrtaceae, mas associadas a Bignoniaceae e Anacardiaceae. Na vegetação de cerrado as mais diversificadas são Leguminosae e Myrtaceae, juntamente com Vochysiaceae, Malpighiaceae e Asteraceae. Interessante notar que as duas famílias mais diversificadas nos três tipos vegetacionais, 
Leguminosae e Myrtaceae, não foram documentadas em Campo Formoso. Outras duas ausências significativas são de Rubiaceae e Vochysiaceae, o que parece sugerir que a maioria dos elementos da vegetação não corresponda nem as florestas estacionais nem ao cerrado.

A família Myrtaceae é considerada bastante comum no domínio atlântico (Rodal \& Nascimento, 2002) e sua ausência poderia sugerir a pequena relevância das espécies mais tipicamente atlânticas na assembléia fóssii.

Alguns comentários podem ser feitos em relação às Leguminosae: há alguns espécimes que poderiam ser identificados como Leguminosae: uma possivel Bauhia e duas espécies de folhas compostas. O estudo florístico de Silva \& Scariot (2003), mesmo tendo sido realizado em floresta estacional, corresponde ao único estudo que não apresenta as Leguminosae entre as mais diversificadas. Este dado parece relevante pelo fato de tal floresta encontrar-se em afloramento calcário, situação relativamente similar a de Campo Formoso, e pode sugerir que tal condição seja pouco propícia para o desenvolvimento de espécimes desta tão importante família.

Embora menos significativo em termos florísticos, devido à identificação apenas em nível de gênero, é interessante observar a maior ou menor penetrância dos gêneros nos diferentes biomas. $O$ gênero Cordia (Boraginaceae), por exemplo, foi registrado em seis das nove listas florísticas de caatinga e em sete das nove listas de florestas estacionais, sugerindo que a presença de tal gênero seria bem provável numa vegetação com mistura florística de espécies dos dois biomas. Ressalta-se a ausência deste gênero nas listas analisadas de cerrado.

Em geral, os dados sugerem que é bem provável a "descida" de espécies da floresta estacional para a região de Campo Formoso, como conseqüencia da melhor distribuição das chuvas, isto é, chuvas distribuídas por mais meses e/ou aumento da precipitação total, e pequena diminuição da temperatura e, devido aos mesmos fatores, a vinda de espécies de cerrado mais aptas à migração. A diversidade das familias registradas seria compatível com a vegetação de caatinga, a qual teria permanecido em Campo Formoso, com as espécies mais adaptadas a condições climáticas mais amenas.

Vale salientar que, pelo menos, sete espécies de folhas pequenas não foram identificadas e que poderiam pertencer a associação de caatinga. Em termos florísticos, a caatinga mostra fortes ligações com a floresta estacional, conforme discutido por Melo (1999). Já foi comentado que esta ligação florística com as florestas estacionais pode vir a mascarar a presença de algumas espécies da caatinga quando se tenta avaliar quais espécies da floresta estacional teriam "descido". 
8.3 - Discussão das informações obtidas pela análise fisionômica dos macrofitofósseis

Os resultados obtidos pelas análises multivariadas indicam que a fisionomia das folhas não é um bom indicador de biomas como um todo, mas permite boas indicações estruturais, que de certa forma refletem condições climáticas. A primeira conclusão importante decorrente da análise referese ao entendimento das características fisionômicas da vegetação de Caatinga. A análise fisionômica da vegetação da Bahia foi norteada pela observação empírica da não concordância da vegetação de caatinga aos padrões internacionais estabelecidos por Wolfe (1993). Não é comum a presença de vegetação decídua em áreas tropicais e a decidualidade da Caatinga pode mascarar a deficiência hídrica, porque suas folhas estão adaptadas aos períodos mais favoráveis.

Ao se estabelecer esta condição fundamental, torna-se mais clara a interpretação dos demais caracteres envolvidos na análise multivariada. O estudo de cada vegetação separadamente e de cada tipo de característica, permitiram a interpretação dos demais parâmetros estudados, corroborados pelas análises comparativas entre duas vegetações e pelas análises de características, incluindo o parâmetro altitude.

Considerando tais análises fisionômicas, pode-se interpretar que a fisionomia da assembléia fóssil assemelha-se a vegetações presentes atualmente em maiores altitudes, conforme sugere a PCA de caatinga acrescida pelo caráter altitude, corroborada pela análise das características dentes e tamanho, na qual a assembléia fóssil encontra-se próxima a vegetações na Chapada Diamantina e a vegetações de dossel fechado. Estando hoje em área de ocorrência de Caatinga, vegetação decídua, a assembléia fóssil estaria sujeita a condições sazonalmente mais úmidas, como as florestas estacionais semideciduas.

A assembléia fóssil de Campo Formoso encontra-se mais próxima à floresta estacional e regiões de contato entre a floresta estacional e caatinga, mas apresenta fisionomia similar a Mata Atlântica. Caso seja comparada à vegetação de cerrado, a assembléia fóssil estaria praticamente isolada, similarmente ao que ocorre quando a caatinga é comparada com a vegetação de campo rupestre, tipo especial de cerrado.

Pode-se concluir, portanto, que, em termos fisionômicos, a assembléia fóssil de Campo Formoso representaria floresta de dossel fechado (como a vegetação atlântica) com características estacionais intermediárias à Caatinga e à Floresta Estacional Semi-decídua. Ao se associar aos dados florísticos a assembléia fóssil de Campo Formoso revela mistura de vegetações, incluindo espécies de cerrado em condições mais úmidas que as atualmente presente na região de caatinga e mais próximas a sazonalidade que ocorre nas regiōes de cerrado e florestas estacionais. 
8.4 - Discussão das informaçōes obtidas referentes ao paleoclima

Considerando-se todas as informaçōes expostas acima, pode-se concluir que o registro fossilífero de Campo Formoso methor distribuição chuvas, originando depósitos calcários ricamente fossiliferos, decorrentes de aporte de água durante, pelo menos, 800 milimetros por ano e melhor distribuida durante o ano, permitindo o avanço da vegetação de cerrado presente no oeste do estado e a descida da floresta estacional presente nas encostas da Chapada Diamantina, originando uma vegetação mista, provavelmente fechada ou parcialmente fechada, bastante diversificada, consequiência natural da mistura vegetacional.

O nordeste possui outros importantes depósitos de tufos inativos como os situados em Russas no Ceará (Duarte \& Nogueira, 1980) e Umbuzeiro na Paraiba (Muniz \& Ramirez, 1971; Duarte, 1979; Duarte \& Vasconcelos, 1980), que seriam indicativos de condições pretéritas mais úmidas, mesmo que de forma eventualmente não sincrônica. Estes estudos são de cunho paleontológico e os depósitos de tufos não foram estudados tafonomicamente. $O$ aumento da umidade, associado a baixas temperaturas, permitiria a expansão de rica floresta galeria, que, segundo De Oliveira et al. (1999) poderia ser o meio pelo qual teria havido intercâmbio florístico entre as regiões amazônica e atlântica, teoria também aceita por estudos mais recentes como Wang et al. (2004). Entretanto, não há nenhum indício de formação de corredores vegetacionais conectando o complexo vegetacional atlântico com a vegetação amazônica, pelo menos não no norte da Bahia. A melhor distribuição das chuvas e/ou o aumento da precipitação anual aparentemente foi muito pequeno para permitir tal conexão. 
9 - Interpretações paleoclimáticas para a América do Sul na fase final da ullima glaciação

9.1 - Fenômenos climáticos na América do Sul

As regiões tropicais da America do Sul são climaticamente diferenciadas pela variação na quantidade e distribuição de chuvas (Rao \& Hada, 1990; Rao et al., 1996). Reconstituições mais detalhadas dos padrões de precipitação ao longo do tempo podem fornecer imagem completa das oscilações climáticas. Atualmente a precipitação na América do Sul tropical é grandemente controlada por movimentos sazonais de deslocamento para norte ou para o sul da ITCZ, que por sua vez é o mecanismo responsável pelo transporte de umidade do oceano Atlântico para o interior da Bacia Amazônica, principalmente no verão e outono austrais. A movimentação da ITCZ é induzida pelo gradiente da temperatura da superficie do mar, entre as faixas tropicais do Oceano Atlântico Norte e Sul. A faixa de nebulosidade que caracteriza a ITCZ possui localização média a $3^{\circ} \mathrm{N}$ e desloca-se levemente para o Hemisfério Sul quando a temperatura superficial no Atlântico Sul é mais alta (Nobre \& Shukla, 1996).

A margem leste do Oceano Pacífico, na regiăo tropical, caracteriza-se por temperatura superficial relativamente fria, causada pela corrente oceânica fria de Humboldt, e relativamente quente no Pacífico oeste, resultando em circulação anticiclônica tanto no oceano quanto na atmosfera. A ressurgência nas costas peruana e equatoriana contribui com águas frias adicionais. A corrente equatorial carrega essas águas ao longo do Oceano Pacífico para oeste, estabelecendo um gradiente leste-oeste na temperatura superficial do mar, denominado Circulação Walker, que influencia fortemente o clima continental. Esse padrão é bastante alterado na fase positiva da Oscilação Sul (SO), fase na qual o evento El Niño pode ocorrer (Kousky et al, 1984).

A fase positiva da SO refere-se à situação na qual o sistema de baixa pressão da Indonésia e o sistema de alta pressão do leste do Pacífico subtropical, estão mais fortes que o normal. Na fase negativa da SO estes dois sistemas são mais fracos (Kousky et al., 1984).

Os distúrbios causados pelo El Niño ocorrem por dois fatores principais: deslocamento da ITCZ e bloqueio do sistema polar frontal do sul do Peru ao sul do Brasil, alterando os padrões de chuva nestas regiões (Martin et al., 1993). O bloqueio é geralmente associado à presença anômala de baixa pressão em latitudes subtropicais e alta pressão em altas latitudes (Kousky et al., 1984).

A SO também afeta a SPCZ, que se estende da Nova Guiné rumo ao sudeste para o Oceano Pacífico Sul. Na fase positiva da SO, a SPCZ permanece a oeste de sua posição usual, sendo importante no bloqueio de massas de ar nas médias altitudes (Kousky et al., 1984). 
A Zona de Convergência do Atlântico Sul (SACZ) corresponde à importante feição climatológica no verão austral da América do Sul, de atividade convectiva, no limite sul da massa de ar tropical úmido, trazida pelos alísios, com altas taxas de precipitação que se desenvolve entre 20-40 $\mathrm{S}, 50-20^{\circ} \mathrm{W}$ numa linha noroeste-sudeste. Estende-se da Amazônia ao sudeste subtropical e Oceano Atlântico extratropical. Tal fenômeno ocorre ao longo do ano todo, mas tem maior atividade no verão, de janeiro a março. Segundo Barreiro et al. (2002), aproximadamente 59\% da variação da SACZ está relacionada a variações internas atmosféricas. Para efeito de comparação, apenas cerca de $20 \%$ da variação de precipitação ocasionada pela ITCZ corresponde à dinâmica interna atmosférica. A variação decadal da SACZ pode ser relacionada com anomalias na temperatura superficial do Oceano Atlântico, mas também está relacionada com ENSO, neste caso independente da temperatura superficial do Atlântico.

O deslocamento atual da ITCZ e da SACZ durante os meses de verão e inverno pode ser observado na figura 35 .

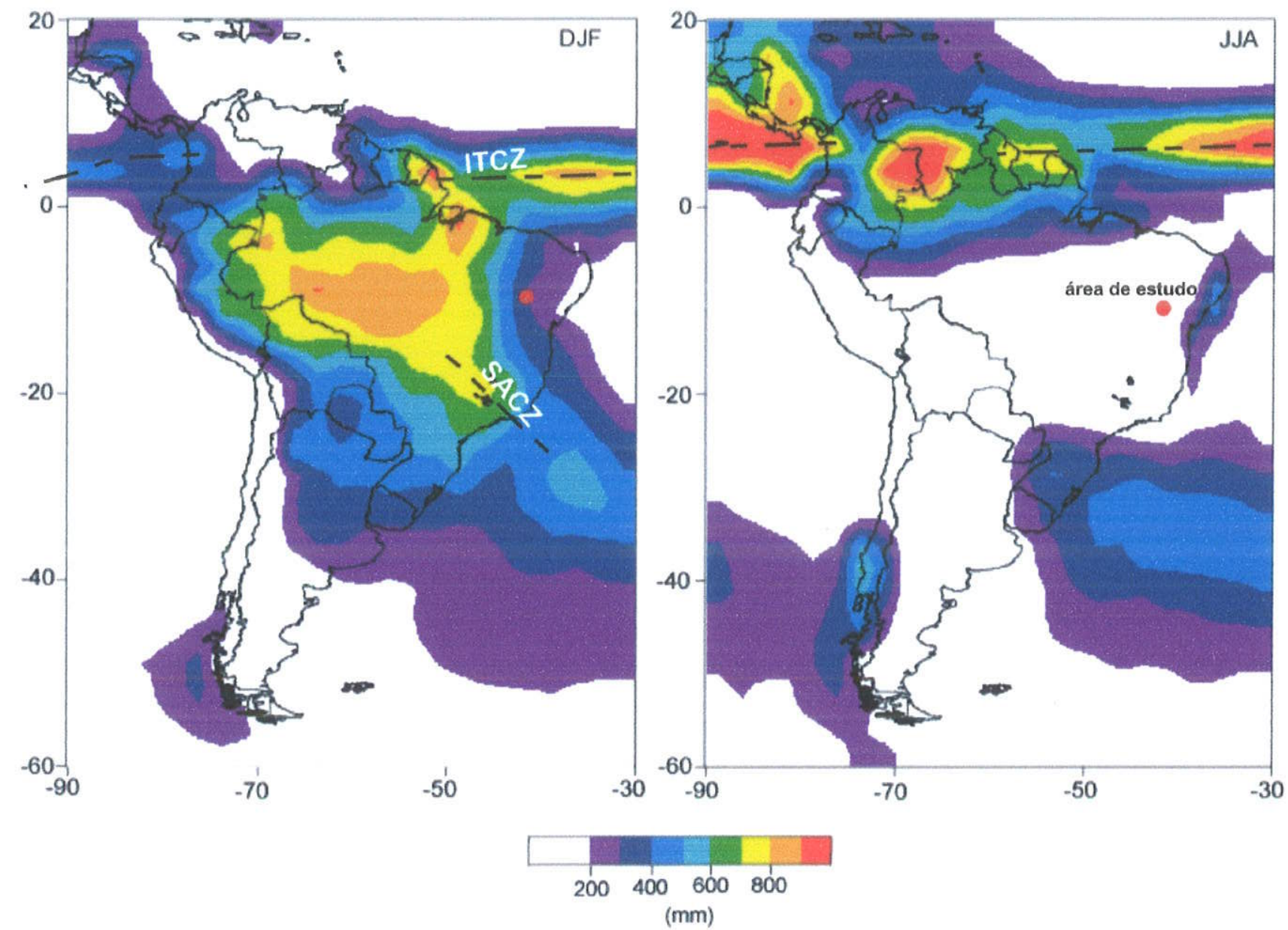

Figura 35 - Precipitação sazonal total na América do Sul, em milímetros, de dezembro a fevereiro à esquerda e de julho a setembro à direita de acordo com Climate Prediction Center Merged Analysis of Precipitation Precipitation. Modificado de Cruz-Júnior et al. (2005). 
A SACZ e a atividade convectiva na bacia amazônica são os componentes principais do sistema sul-americano de monções (SAMS) segundo Jones \& Carvalho (2002), que demonstraram que as variações intersazonais que ocorrem entre dezembro e fevereiro no regime de ventos sobre a América do Sul tropical estão ligadas a fases de atividade e inatividade da SAMS. Por outro lado, em escala de tempo mais ampla, as variações interanuais estão associadas com a ENSO

O desenvolvimento da SAMS inicia-se durante a primavera, de setembro a novembro, como uma convecção profunda, que se desenvolve primeiro no noroeste da Amazônia, progredindo em direção sudeste, atingindo o sudeste do Brasil na metade de outubro. O transporte de umidade e intensidade máxima da precipitação ocorrem no verão. Durante o inverno, o fluxo tende a ser zonal, enquanto que no verão, o fluxo é mais fraco e mais meridional, especialmente perto da costa leste e oeste da América do Sul. Durante o verão austral, o anticiclone troposférico superior, conhecido como Alto Boliviano, é observado sobre a Bolivia e uma região de baixa pressão aparece sobre o Oceano Atlântico próximo à costa do nordeste do Brasil. A convecção profunda inicia-se sobre a porção noroeste da América do Sul, com conexão a ITCZ do Pacífico, havendo posteriormente conexão com a ITCZ do Atlântico. Por outro lado, fortes frentes frias durante o verão podem, ocasionalmente, atingir as baixas latitudes, contribuindo com precipitações acima da média e pode ser um importante modulador da intensidade e posição da SACZ (Gan et al., 2004).

A ENSO parece alterar a persistência da SACZ, independente da sua intensidade, sendo sua influência maior nas fases quentes. Os resultados também mostraram que a variabilidade da SACZ aparenta estar mutuamente relacionada com a SAMS, sugerindo que os mecanismos responsáveis pelas variações na intensidade do primeiro determina feições de larga escala no segundo (Carvalho et al., 2004).

O sistema ENSO é normalmente considerado como o melhor exemplo da interação oceano / atmosfera e uma das mais relevantes manifestações da variabilidade interanual no sistema climático global. Embora o fenômeno seja observado primariamente no Oceano Pacífico equatorial, chega a induzir anomalias climáticas nas áreas tropicais e extratropicais (Ortlieb \& Macharé, 1993).

A sigla ENSO refere-se então às feições de grande escala, sejam elas intertropicais, inter oceânicas ou globais enquanto o termo El Niño refere-se especificamente às manifestações regionais centradas na margem leste do Oceano Pacífico e oeste da América do Sul. As atividades do E1 Niño representam o componente leste do fenômeno ENSO.

As manifestações do El Niño estão relacionadas às modificações da circulação Walker e no deslocamento da ITCZ para o sul, ocasionando mudanças nas precipitações: excepcionais em regiões costeiras normalmente áridas ou semi-áridas do noroeste do Peru e sul do Equador; intensificadas na região central do Chile, no Paraguai e no norte da Argentina; diminuidas 
significativamente no altiplano sudeste do Peru e Bolivia e aumentadas no nordeste brasileiro, na porção norte da América do Sul e na parte sul da América Central (Ortlieb \& Macharé, 1993). Os eventos quentes da ENSO enfraquecem a intensidade da ITCZ no Atlântico durante o verão austral. Durante o verão austral, a célula Hadley já é mais fraca que durante o inverno, ficando ainda mais fraca com o enfraquecimento da ITCZ. Além disso, a geração de uma anomalia ciclônica fora da costa do sul do Brasil e Uruguai, enfraquece o Alto Subtropical local (Barreiros et al., 2002).

Do ponto de vista oceanográfico, o fenômeno ENSO é caracterizado pela elevação da temperatura superficial no Oceano Pacífico equatorial (a leste de $130^{\circ} \mathrm{W}$ ) e pela diminuição da termóclina ao longo da costa oeste sul-americana, acompanhada pela alteração no sistema de ressurgência e conseqüente decréscimo na produtividade primária. A presença ou ausência de organismos nas sequêencias sedimentares e modificações bioquímicas nos esqueletos de organismos marinhos como corais, moluscos, foraminiferos e dinoflagelados constituem evidências dessas alterações ao longo do tempo (Ortlieb \& Macharé, 1993)

Pode-se observar a grande interrelação entre os diversos fenômenos climáticos apresentados. A variação de apenas alguns parâmetros pode alterar todo o quadro climático e até mesmo configurar periodos glaciais e interglaciais.

9.2 - Interpretação de fenômenos paleoclimáticos com ênfase nos periodos glaciais

As regiões temperadas do hemisfério norte exibem as maiores flutuações climáticas durante as glaciações quaternárias. Ocorreram modificações de padrões atmosféricos, da biota, dos processos isostáticos, da descarga de águas de derretimento de gelo, dos tipos de sedimentos de rios e oceanos e outros fenômenos. Todas essas variações têm mostrado forte assimetria entre os dois hemisférios.

As perturbações orbitais, ligadas às mudanças climáticas, ocorrem com freqüência não inferior a 40.000 e 20.000 anos, de modo que outros mecanismos devem ser procurados para explicar flutuações de intervalos curtos. Para tanto, o tipo, magnitude e distribuição geográfica de tais flutuações devem ser determinadas. Breves alterações nos isótopos de oxigênio têm sido registradas em microfósseis calcários, refletindo mudanças na composição isotópica dos oceanos, assim como fracionamento isotópico durante evaporação e condensação e subseqüente estoque de água nas calotas de gelo. Esses registros sugerem dois ou três estágios de redução do volume de gelo entre 15.000 e 8.000 anos atrás (Wright Jr., 1989). 
Algumas subdivisões paleoclimáticas do Quaterrario referentes à Escandinávia tèm sido tentativamente utilizadas para o restante do mundo como Oldest Dryas, Bölling, Older Dryas, Alleröd, Younger Dryas e Pré-boreal. Esses estágios são locais ou no máximo regionais. Sugere-se que o intervalo correspondente a Alleröd seja denominado, mais adequadamente, de mudança climática européia. O resfriamento referente ao Younger Dryas representa um evento muito drástico. Embora sem correlação comprovada no restante do mundo, estes eventos demonstram que as oscilações climáticas podem ocorrer rapidamente e, ás vezes, com efeitos locais.

Considerando-se que as fases glaciais são caracterizadas pelo aumento das calotas polares, a circulação oceânica é grandemente modificada durante estas fases. Em conseqüência, o padrão de circulação atmosférica também é alterado.

A circulação atmosférica na América do Sul durante o último máximo glacial é assunto controverso. Os estudos baseados primariamente em depósitos terrestres como os palinológicos, geomorfológicos, pedológicos e glaciológicos devem ser confrontados com dados obtidos de testemunhos marinhos para resolver esta controvérsia.

9.3 - Caracterização da circulação no Oceano Atlântico na última glaciação

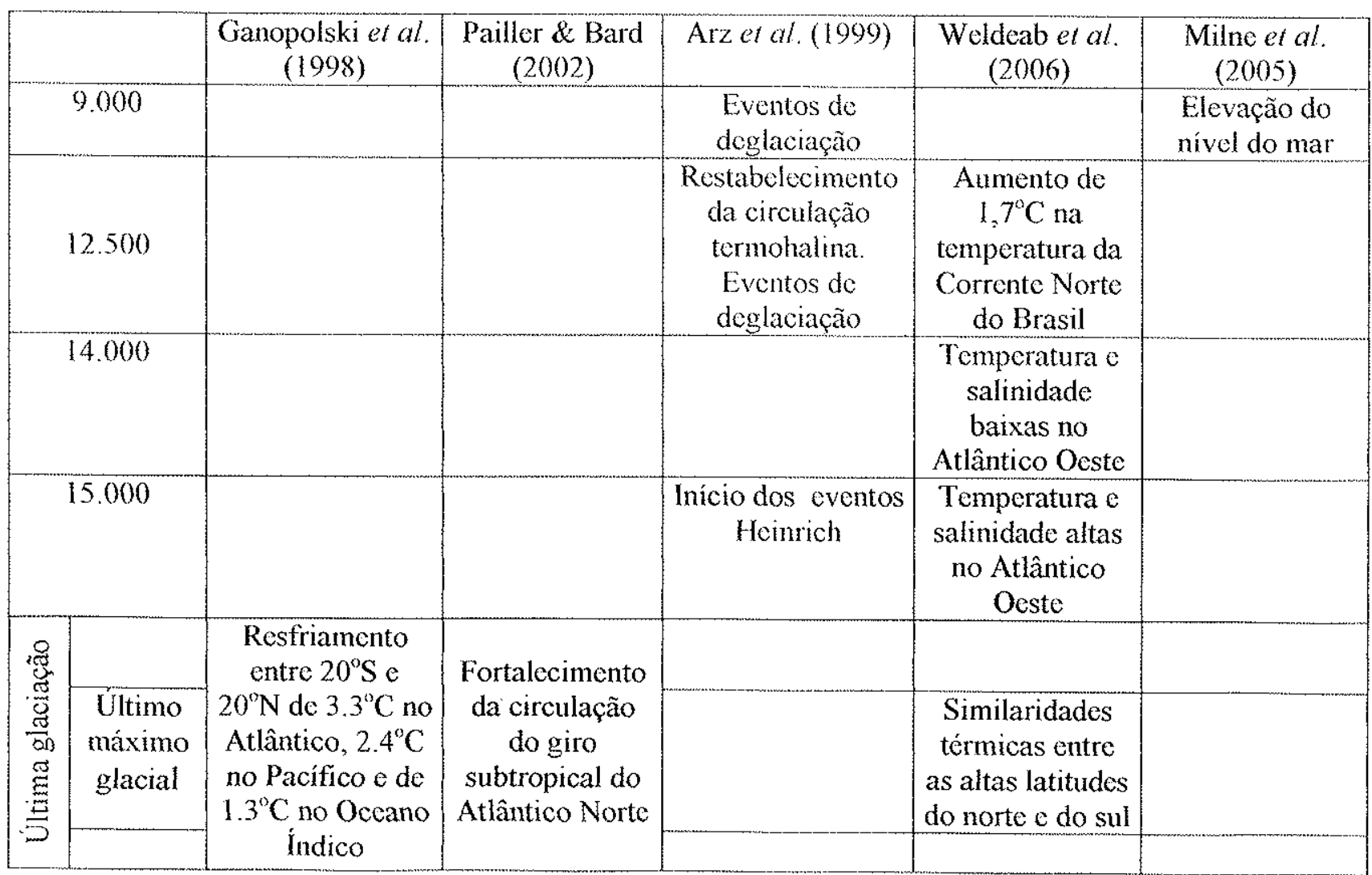

Tabela 13 - Síntese dos principais dados sobre os eventos oceânicos durante a última glaciação e a transição para o pósmglacial. 
As temperaturas dos oceanos tropicais vêm causando polêmicas desde que o CLIMAP estimou as temperaturas do planeta durante a última glaciação. O CLIMAP indicou, baseando-se em foraminiferos planctônicos, que as temperaturas dos oceanos tropicais quase não sofreram alterações (Weyl, 1978). Muitos trabalhos paleoclimáticos utilizaram esses dados como base de suas interpretações, até que o registro de corais mostrou evidências de resfriamento também nas regiões oceânicas tropicais, contradizendo as estimativas oriundas dos foraminiferos. A análise de isótopos de oxigênio associada às proporçōes de $\mathrm{Sr} / \mathrm{Ca}$, permitiram estimativas mais confiáveis indicando resfriamento de 5 a $6^{\circ} \mathrm{C}$ (Beck et al., 1997).

Simulações posteriores, baseadas no acúmulo de informações cada vez mais precisas, auxiliam no registro dos últimos eventos glaciais e pós-glaciais. A simulação de Ganopolski et al. (1998), por exemplo, registrou resfriamentos entre as latitudes $20^{\circ} \mathrm{S}$ e $20^{\circ} \mathrm{N}$ de $3.3^{\circ} \mathrm{C}$ no Atlântico, $2.4^{\circ} \mathrm{C}$ no Pacífico e de $1.3^{\circ} \mathrm{C}$ no Oceano Índico, valores compatíveis com o resfriamento de cerca de $5^{\circ} \mathrm{C}$ no continente. Segundo Bush \& Philander (1998) resfriamentos de 2 a $3^{\circ} \mathrm{C}$ nos oceanos durante o último máximo glacial seria resultado da diminuição do $\mathrm{CO}_{2}$ atmosférico. As interações oceanoatmosfera responderam primariamente com o resfriamento tropical de 4 a $6^{\circ} \mathrm{C}$ no oeste do Pacífico, fortalecimento dos ventos, aumento da inclinação da termóclina e aumento na velocidade das correntes Equatorial Sul e Equatorial Profunda, que aumentaram a ressurgência, aumentando o resfriamento. As regiões interiores, sobre os continentes tropicais, teriam resfriamento de 5 a $6^{\circ} \mathrm{C}$ de acordo com Stute et al. (1995).

Conforme indicado pela tabela 13, na página anterior, a última fase glacial foi caracterizado pelo fortalecimento da circulação do giro subtropical do Atlântico Norte. Entre muitos trabalhos no Atlântico Norte, registros dos testemunhos MD95-2040 e MD9-2042 sugerem que durante a última glaciação, ocorreram diversas variações na produtividade e nas temperaturas superficiais relacionadas a cada evento Heinrich de derretimento dos escudos de gelo, que alteraram a circulação termohalina e os ciclos climáticos Dansgaard - Oeshger. (Pailler \& Bard, 2002). As modificações climáticas decorrentes podem ser observadas nas figuras 37, 38 e 39 (páginas 171 a 173).

A transição do último glacial para o atual interglacial não foi contínua. Vários eventos de resfriamento de curta duração interromperam a deglaciação. Um efeito importante desse mecanismo foram os eventos Heinrich com conseqüente aumento do nível do mar em cerca de 120 metros. $O$ derretimento episódico do gelo afetou a circulação termohalina a partir de 18.000 anos calibrados, que só se restabelece a cerca de 15.000 anos atrás calibrado (Arz et al., 1999). Na circulação termohalina atual, as águas perdem calor para a atmosfera no Atlântico Norte, conseqüentemente ficam frias e mais densas, afundando e retornando ao sul como águas profundas. $O$ enfraquecimento 
desta circulação pelo derretimento de geleiras ou por outros meios, reduz o transporte de calor para o Atlântico Norte, resfriando o clima na regiäo e retendo calor na região tropical, entre as profundidades 200 e 1.000 metros (Arz et al., 1999; Chiang \& Koutavas, 2004).

Wang et al. (2004) identificam sincronia entre os periodos úmidos no Nordeste Brasileiro com o enfraquecimento da monção de verão do leste asiático e com os eventos Heinrich, provavelmente devido ao deslocamento da ITCZ para o sul.

Águas superficiais mais quentes no Atlântico Sul, durante cada evento Heinrich induziram o enfraquecimento do gradiente de temperatura entre o oeste e o sul do Atlântico, resultando numa Corrente Norte do Brasil menos vigorosa (motivada pela redução da intensidade dos ventos) porém quente e salina. Corresponderia a um mecanismo adicional ao do enfraquecimento do giro subtropical para a acumulação de sal no Atlântico Oeste tropical, juntamente com a Corrente Norte do Brasil quente e salina, o deslocamento da ITCZ e o fortalecimento dos ventos de nordeste, resultando na acumulação e estagnação de massas de água quentes e salinas em todo o Atlântico Oeste tropical (Weldeab et al., 2006). O registro de corais de Barbados evidencia este estoque de águas quentes (Guilderson et al., 1994). Os registros da Bacia de Cariaco, Venezuela e das condições úmidas no Nordeste Brasileiro sugerem o deslocamento da ITCZ para o sul e a intensificação dos ventos de nordeste (Peterson et al, 2000; Wang et al, 2004).

Entretanto, os eventos Heinrich não correspondem ao único ciclo climático proeminente. Os eventos de duração milenar Dansgaard-Oeschger são registrados no gelo da Groenlândia e em registros paleoclimáticos detalhados no Hemisfério Norte. Nestes registros, os eventos Heinrich mostram-se secundários em relação à freqüência e amplitude do ciclo Dansgaard-Oeschger. Outros registros mostram melhor correlação com os eventos Heinrich, entre eles, o testemunho sedimentar da margem continental brasileira (Broecker \& Hemming, 2001).

Utilizando-se testemunhos no Atlântico Sul (GeoB 1711), no Atlântico Equatorial (GeoB 1515) e no Atlântico Norte (SU 90-08 e NA 87-22) também se pode constatar a relação entre os eventos de aquecimento que ocorreram 1.500 anos antes no Atlântico Sul em relação ao Atlântico Norte e que estão relacionados com a quebra da circulação termohalina (Vidal et al., 1999).

Na transição da fase glacial para a interglacial, cerca de $70 \%$ do gelo sobre os continentes derreteram, causando grande aumento do volume os oceanos, acompanhados de resposta isostática da Terra sólida. O aumento do nível do mar foi relativamente rápido e uniforme, cerca de 7 a 8 milímetros por ano, durante o início do Holoceno (8.500 anos calibrados). Os dados também sugerem decréscimo na taxa de derretimento ao redor de 7.000 anos (Milne et al., 2005) 
9.4 - Situação paleoclimática durante o último máximo glacial na América do Sul.

As informações e discussões paleoclimáticas aqui expostas, se iniciam do sul do continente sulmamericano, acompanham os Andes até a Amazônia para entăo atingir o Brasil Central e posteriormente o nordeste, área de estudo, muito embora as discussões estejam mais concentradas nas regiões brasileiras. Dados oceânicos são utilizados para melhor compreensão de alguns fenômenos envolvidos. Síntese de dados paleoclimáticos pode ser observada desde 22.000 anos não calibrados até 8.000 anos atrás (9.000 anos calibrados) em intervalos de 2.000 anos através das figuras 37 a 44 (páginas 171 a 178).

\section{WESTERLIES OU VENTOS DE OESTE, CIRCULACCAO SUBTROPICAL E FRENTES POLARLS.}

Na América do Sul, as informações sobre a circulação oeste, intensidade da corrente de Humboldt e penetração das frentes polares, são relevantes porque podem explicar, em parte, a própria glaciação e, em parte, fornecer informações sobre o deslocamento de anticiclones atmosféricos e convergências oceânicas, que alteram praticamente todos os fenômenos climáticos.

A simulação realizada por Wyrwoll et al. (2000) para o Hemisfério Sul sugere o deslocamento dos ventos de oeste para o pólo, mas de forma generalizada, já que sua atuação latitudinal tornou se maior, ocasionando diferenças regionais durante o último máximo glacial.

Como consequiencia destas diferenças regionais causada pela mudança do padrão de atuação dos ventos de oeste, têm-se condições mais úmidas durante o máximo glacial nos subtrópicos, como por exemplo nas latitudes médias e baixas $\left(<30^{\circ}\right)$ da região andina (Van Geel et al., 2000), devido aos ventos mais fracos, enquanto em latitudes mais altas, com temperaturas superficiais dos oceanos mais frias, há menor influxo de umidade vindo do Atlântico (Wainer $e t$ al., 2005).

Nesse ponto é importante ressaltar uma característica climática e paleoclimática da América do Sul: os registros climáticos do Pampa e da Venezuela são nitidamente diferentes, mas não são independentes um do outro, mostrando correlação inversa, com períodos secos no sul correspondem praticamente a períodos úmidos no norte e vice versa. No fenômeno $\mathrm{E}$ l Niño, ocorrem fortes chuvas nos pampas e estiagens severas na Colômbia e Venezuela, ocorrendo o inverso no fenômeno La Niña. Essa hipótese, de climas opostos, vem se tornando mais forte em face às interpretações paleoclimáticas produzidas na América do Sul. Em ambos os lados da Cordilheira do Equador, no lado leste dos Andes no Peru e Bolívia e na região dos lagos do Chile, são descritos paleoclimas semelhantes aos padrões da Patagônia. Por outro lado, a Amazônia Central, o Altiplano Boliviano e o norte do Chile seguem os padrões presentes na Venezuela. Um terceiro padrão de evolução climática é observado ao sul da latitude $40^{\circ}$ na Patagônia e Terra do Fogo, devido à descontinuidade 
da cordihheira, baixa altitude e porção continental estreita, com influências na migração das ondas de oeste e posição da frente polar (Iriondo, 1999; Paegle \& Mo, 2002; Pessenda et al, 2005; Wainer et al., 2005)

As informações sobre a posição dos ventos de oeste, anticiclone do Atlântico Sul, frentes polares e sobre os diferentes paleoclimas estão ilustrados nas figuras 37 a 43 (páginas 171 a 177).

\section{AMAYONNIA E SUA COBERTURA VEGETACIONAI.}

Inferências paleoambientais palinológicas sugerem dois cenários alternativos para as terras baixas da Amazônia durante a última glaciação:

a) floresta sempre-verde permanente, com invasões de elementos adaptados ao frio durante a fase glacial, quando a temperatura era cerca de $6^{\circ} \mathrm{C}$ mais fria (Haberle \& Maslin, 1999; Bush et al., 2000; Colinvaux \& De Oliveira, 2001);

b) substituição da comunidade arbórea por comunidade herbácea xerófita (Absy et al., 1991; Van der Hammen \& Absy, 1994; Behling \& Hooghiemstra, 2000).

Reanalisando oito registros polínicos, Van der Hammen \& Hooghiemstra (2000) interpretam a evolução da vegetação amazônica desde o Terciário. A temperatura durante o último máximo glacial teria sido $8^{\circ} \mathrm{C}$ mais fria nos Andes e possivelmente de 4 a $5^{\circ} \mathrm{C}$ mais fria nas terras baixas. A diferença entre a fase pleniglacial fria e úmida (60.000 a 28.000 anos atrás, não calibrado) e a fria e seca do pleniglacial tardio (28.000 a 13.000 anos atrás), que inclui o último máximo glacial, é evidente através do registro de palinomorfos tanto nos Andes quanto nas terras baixas tropicais. Durante o pleniglacial superior o clima foi relativamente frio e seco na Amazônia. Há regiões com savanas e florestas tropicais secas. Dunas se desenvolveram em áreas atualmente com savanas. As chuvas no norte da América do Sul podem ter sido reduzidas em 30 a 50\%. Ao redor de 20.000 anos atrás, essa redução de precipitação seca totalmente vários lagos na Amazônia e nos Andes.

Em Rondônia, a distribuição da savana e/ou cerrado não depende de fatores edáficos. Dados de subsolo sugerem maior desenvolvimento em tempos pretéritos desta vegetação, inclusive com dados sugestivos da ocorrência de fogo, embora a datação deste evento não seja possível devido às limitações dos isótopos de ${ }^{14} \mathrm{C}$. Aparentemente o pleno desenvolvimento das florestas tropicais ocorreu entre 10.000-9.500 a 8.000 anos, enquanto as savanas e/ou cerrados começam a se desenvolver há 8.000 atingindo o máximo a 6.000 - 5.000 anos (Desjardins, et al, 1996).

Pessenda et al. (1998) estudaram solos de três localidades em Rondônia: Vilhena, mais ao sul, representativa de cerrado; Pimenta Bueno correspondente à transição entre cerradão e floresta e Ariquemes mais ao norte, com vegetação de floresta. Os dados isotópicos de carbono orgânico dos solos sugerem que não houve mudanças significativas na localidade que hoje apresenta floresta, 
enquanto que as áreas hoje dominadas por cerrado e cerradão, testemunhariam a expansão da floresta ao longo do Holoceno Inferior (10.000 - 8.000), expansão das savanas no Holoceno Médio $(8.000 \sim 4.000)$ e novamente a expansão da floresta no Holoceno Superior.

Em relação à transição campo-floresta em Humaitá, sul do Amazonas, quase no Estado de Rondônia, Gouveia et al. (1997) interpretam que entre 12.000 e 8.000 anos, toda a área de estudo teria sido coberta por floresta, estando a vegetação predominante de plantas $\mathrm{C}_{3}$ mais desenvolvida $\mathrm{e}$ com maior biomassa ao redor de 10.800 anos.

Comparando-se os dois cenários alternativos com outros registros sul-americanos, o primeiro cenário (floresta sempre-verde) parece ser mais provável. Há poucas indicações de grandes mudanças nas estruturas vegetacionais, relacionadas às rápidas mudanças climáticas que ocorreram ao longo deste intervalo. A hipótese de substituição da comunidade arbórea pela comunidade herbácea sugere o deslocamento de cada bioma como um todo, hipótese associada à teoria dos refúgios, na qual a floresia se retrai, permitindo a expansão dos campos, enquanto que as "ilhas" de floresta representariam verdadeiros refúgios de fauna e flora. Na hipótese de manutenção da estrutura florestal, as espécies mais susceptíveis tenderiam a desaparecer, enquanto que algumas espécies de regiões vizinhas aptas a migrarem, acompanhariam as mudanças climáticas, alterando a composição florística ao formar mosaicos de espécies de diferentes biomas atuais. Algumas espécies não são aptas a migrarem pela ausência de polinizador ou dispersor que sejam aptos a migrarem. As comunidades em mosaico pode ser melhor caracterizadas em associaçŏes de macrofitofósseis como é o caso em Campo Formoso, principalmente devido à evidência de pequeno transporte dos seus elementos constituintes. Deve-se levar em consideração que ao contrátio de associações polínicas que são sempre de caráter regional, os registros macrofitofossilifero refletem melhor os aspectos locais da cobertura vegetal e corroboram a hipótese de manutenção da floresta.

A Amazônia foi predominantemente florestada durante o último máximo glacial, embora haja evidência de expansão de savanas em suas margens. O que os novos dados biogeográficos modernos sobre disjunções de espécies sugerem é a possibilidade da Bacia Amazônica ter sido recoberta por florestas sazonalmente secas ao invés de floresta pluvial. Entre o último máximo glacial e a metade do Holoceno, teria havido grande expansão da floresta sempre-verde sobre a floresta decídua, atribuída ao aumento da temperatura e dos níveis atmosféricos de $\mathrm{CO}_{2}$. As similaridades entre o padrão de mudanças no ecossistema amazônico e o registro de metano na Groenlândia, implicam que a Amazônia desempenhou importante papel na diminuição do fluxo de metano atmosférico durante a transição da última glaciação para o Holoceno (Mayle \& Beerling, 2004). 


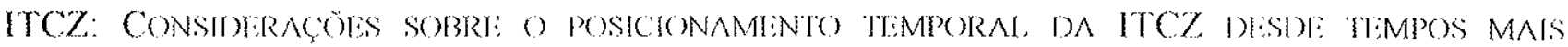
ANTKios (31): 8.000 ANOS.

Fenômenos que ocorrem a partir de 8.000 anos podem ser utilizados por fornecer subsidios ao entendimento das variações climáticas ao longo da última fase glacial. O norte da América do Sul fornece subsidios para as discussões sobre o posicionamento temporal da ITCZ.

Os estudos feitos no norte da América do Sul, especialmente Venezuela, mostram climas periodicamente mais úmidos que os atuais durante o Quaternário, contrariamente ao observado no Brasil e Bolivia. Por analogia às mudanças atuais, estimamse que tais mudanças climáticas seriam causadas por variações na posição da ITCZ, associadas a reforço dos anticiclones subtropicais nas latitudes sul (Servant et al., 1989).

No inicio dos eventos Heinrich, a intensidade da precipitação aumentou rapidamente nas regiões nas quais o verão austral é chuvoso, mas essa maior precipitação não ocorreu ao longo do ano inteiro, mas somente nos meses de verão. O Nordeste Brasileiro apresenta clima semi-árido, com estação seca de 8 meses, e as florestas pluviais não resistem a secas mais prolongadas que 4 meses, mas a medida que o evento Heinrich se estabelece, a precipitação se distribui melhor ao longo do ano, permitindo o desenvolvimento de florestas pluviais. Os eventos Heinrich anteriores a deglaciação foram menos intensos, provavelmente não alterando a sazonalidade das chuvas, não sendo possível modificações na vegetação. Jennerjahn et al. (2004) sugerem o deslocamento para o sul da ITCZ, conforme pode ser observado na figura 36, no Holoceno, este deslocamento acaba por afetar a ENSO, pois a migração da ITCZ para o sul aquece as águas superficiais do Pacifico, originando o fenômeno El Niño. Desse modo, fica claro como eventos oceânicos (Heinrich) podem alterar a circulação atmosférica (ITCZ) que por sua vez é capaz de modificar os padrões oceânicos (ENSO), sendo, muitas vezes, difícil caracterizar causa e efeito.

\section{SACZ: A RELAÇÃo ENTRE: A AMAZÔNIA E O OCEANO ATLÂNTICO DEFININDO O Clima dO SUDESTE BRASLEIRO}

A área palinologicamente bem estudada e considerada pelos seus autores como situada no Brasil Central, corresponde de fato ao Estado de Minas Gerais com apenas dois registros fora dele: Águas Emendadas, DF e Cromínea, GO (Barberi-Ribeiro, 1994; Ferraz-Vicentini \& SalgadoLabouriau, 1996; Barberi et al., 2000). Os registros de Minas Gerais são extensos: Lagoa dos Olhos, Lagoa Santa, Lagoa Campestre em Salitre, Serra Negra, Catas Altas, Lago do Pires e Lago Dom Helvécio (De Oliveira, 1992; Parizzi, 1993; Behling, 1995; Ledru et al., 1996; Salgado-Labouriau et al., 1997; Behling \& Lichte, 1997; Behling, 1998; Parizzi et al., 1998; Turcq et al., 2001). De modo geral os registros dessa região indicam clima seco durante a última glaciação, com vegetação 
campestre e secamento de lagos. Há algumas variações no início e no final dessa fase seca, mas não há muitas discrepâncias entre os registros.

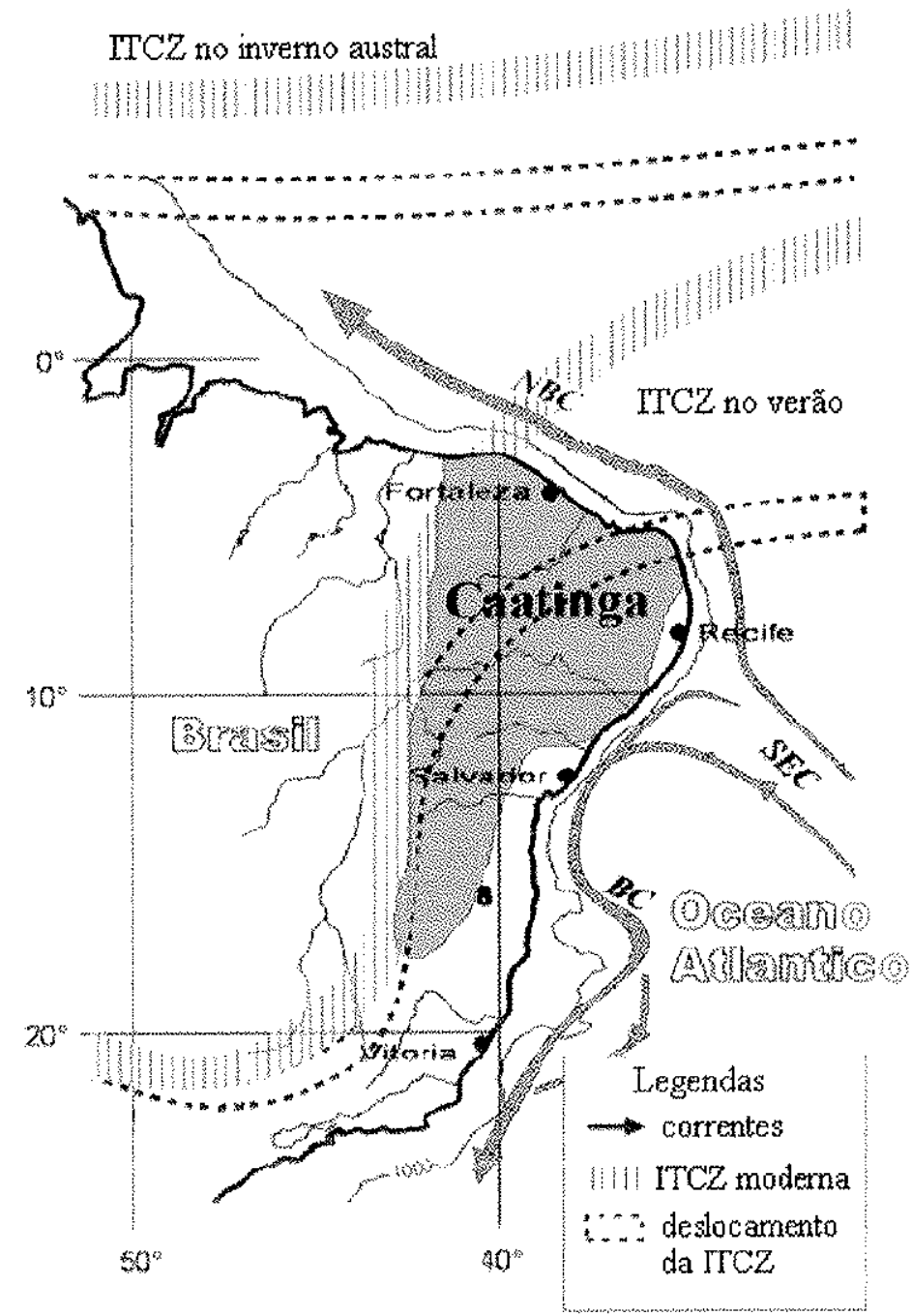

Figura 36 - Posição da ITCZ atual e seu possível deslocamento durante os eventos Heinrich. NBC Corrente Norte do Brasil, SEC - Corrente Sul Equatorial e BC - Corrente do Brasil, na região do Giro Subtropical. Modificado de Jennerjahn et al. (2004).

Os dados da Amazônia, como o aumento do nível do Lago Valência, e do Brasil Central sugerem que, no intervalo de 10.000 a 8.000 (11.400 a 8.900 anos atrás calibrado), correspondente ao ótimo climático em Carajás, o clima seria mais úmido. Em Salitre, após um breve episódio frio e seco ao redor de 10.500 anos (12.400 anos atrás calibrado), houve rápido restabelecimento da cobertura arbórea. Em contraste, os níveis dos lagos diminuem no altiplano boliviano ao redor de 8.000 anos (8.900 anos atrás calibrado). De 10.500 e 8.000 (11.400 e 8.900 anos atrás calibrado) na Bolívia, as condições eram mais secas no Lago Sibéria e Titicaca enquanto persistem condições quentes e úmidas no leste da Amazônia, ao mesmo tempo em que ocorreu fase fria e úmida no Brasil central, como em Salitre. 
Figura 37 - Mapa paleoclimático da América do Sul há 22.000 anos não calibrado.

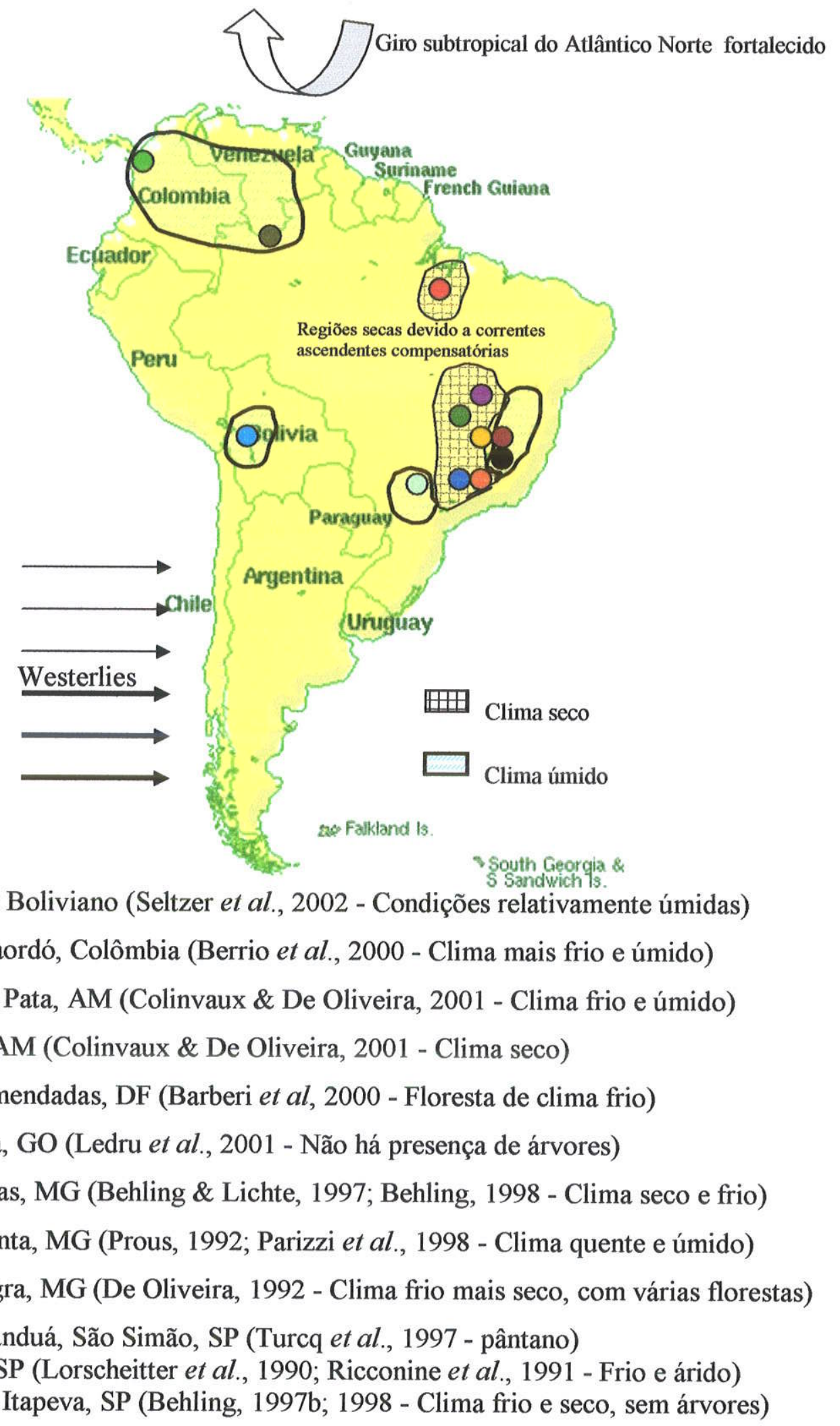


Figura 38 - Mapa paleoclimático da América do Sul há 20.000 anos não calibrado.

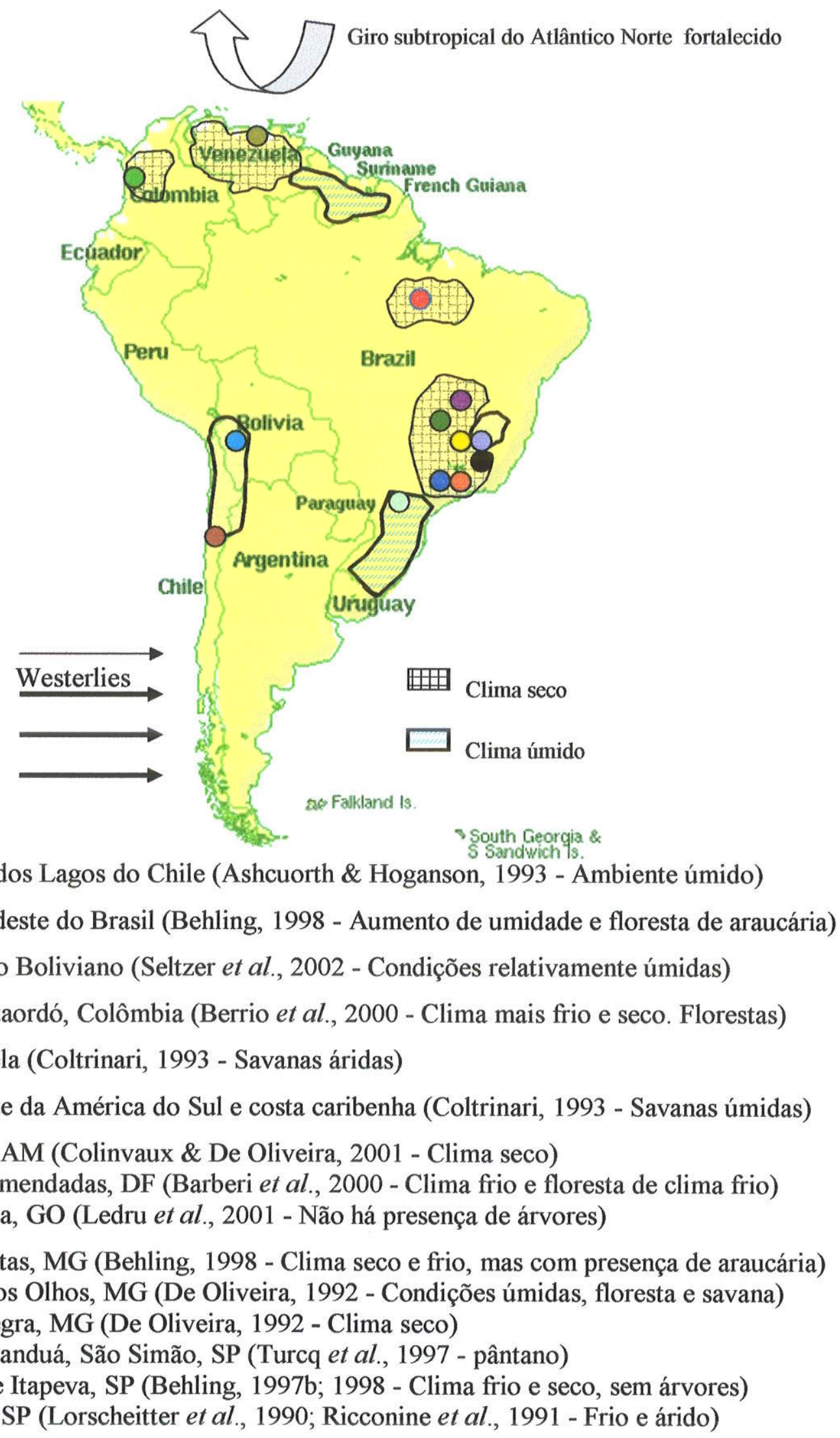


Figura 39 - Mapa paleoclimático da América do Sul há 18.000 anos (21.500 anos calibrado)

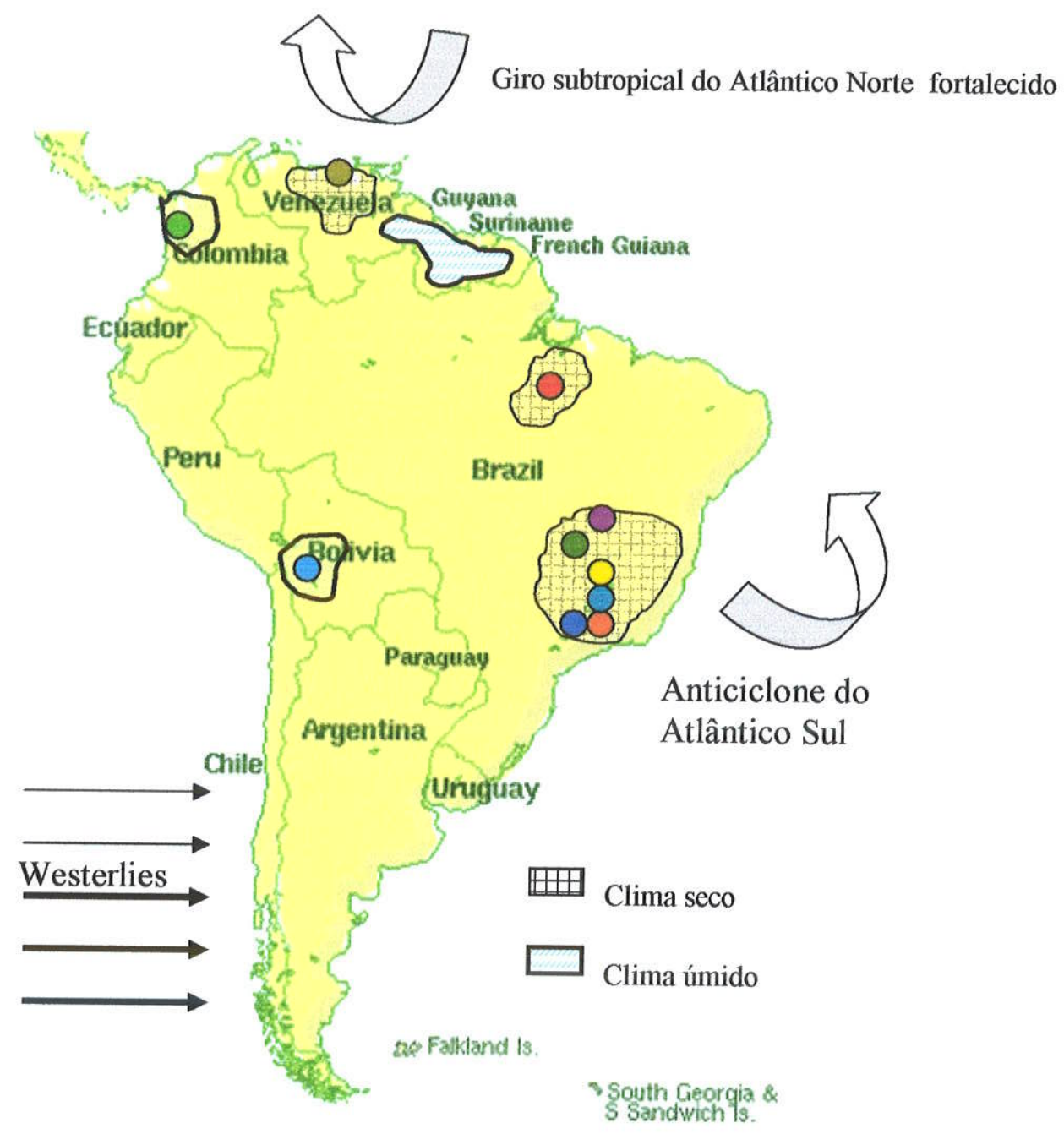

Altiplano Boliviano (Seltzer et al., 2002 - Condições relativamente úmidas)

Lago Jotaordó, Colômbia (Berrio et al., 2000 - Floresta diversificada desde 20.000)

Venezuela (Coltrinari, 1993 - Savanas áridas)

Nordeste da América do Sul e costa caribenha (Coltrinari, 1993 - Savanas úmidas)

- Carajás, AM (Colinvaux \& De Oliveira - Presença de savanas)

- Águas Emendadas, DF (Barberi- Ribeiro,1994; Barberi et al., 2000 - Desertificação)

Cromínea, GO (Ledru et al., 2001 - Longa fase seca)

Catas Altas, MG (Behling \& Lichte, 1997; Behling, 1998 - Clima seco e frio com fortes geadas. Campos e pequenas áreas de floresta galeria subtropical com presença de araucária)

- Salitre, MG (Alexandre et al., 1999; Turcq et al., 1997; Ledru, 1992 - fase fria e seca)

Colônia, SP (Lorscheitter et al., 1990; Riccomine et al., 1991 - Frio e árido)

Morro de Itapeva, SP (Behling, 1997b; 1998 - Clima frio e seco, sem árvores) 
Figura 40 - Mapa paleoclimático da América do Sul há 16.000 anos (19.500 anos calibrado).

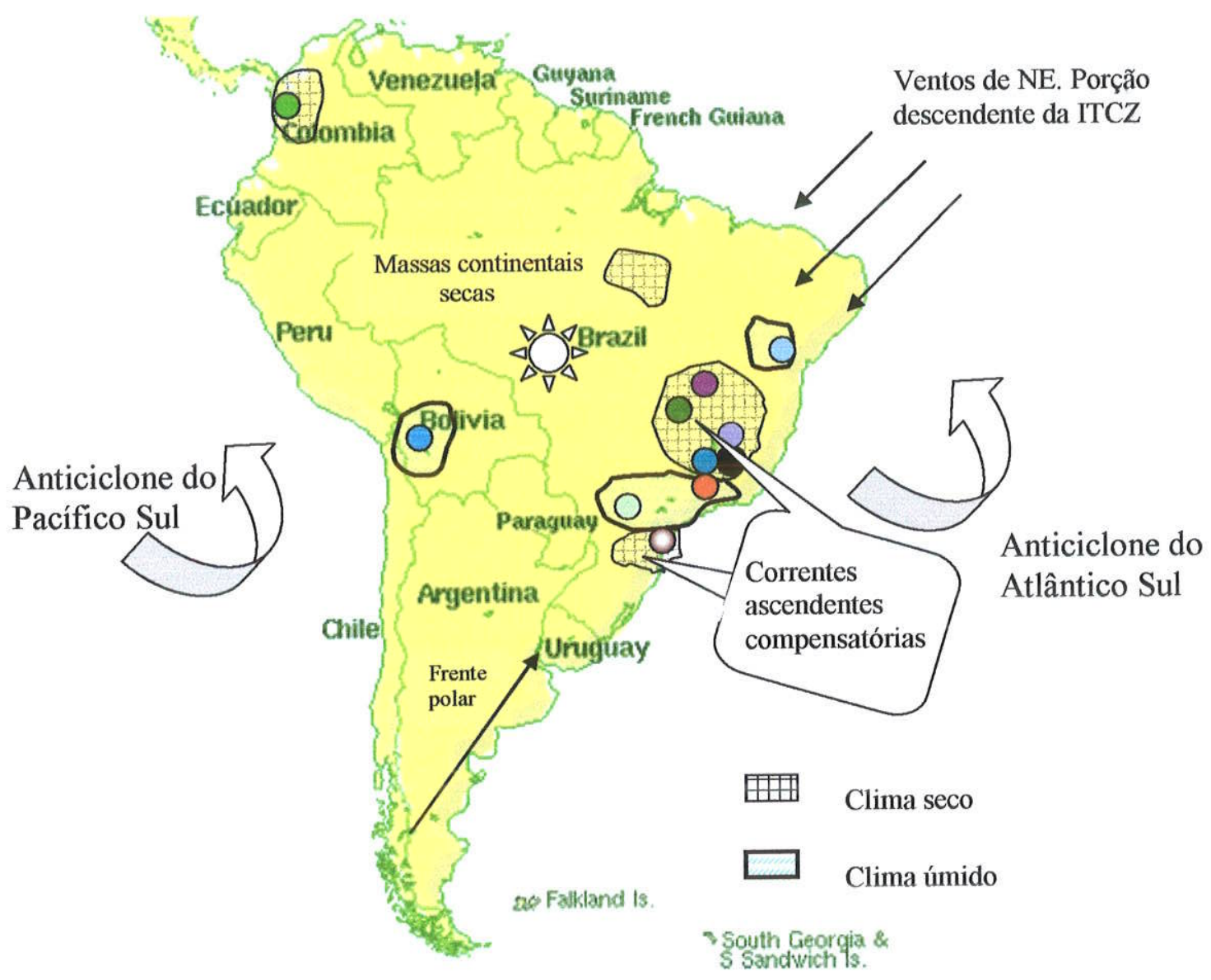

Vale do Ribeira, SP (Cruz-Júnior et al., 2005 - Período seco entre 20.000 e 18.000 anos atrás calibrados)
Altiplano Boliviano (Seltzer et al., 2002 - Condições relativamente úmidas)

Lago Jotaordó, Colômbia (Berrio et al., 2000 - Floresta diversificada desde 20.000)

- Águas Emendadas, DF (Barberi-Ribeiro, 1994; Barberi et al., 2000 - Semi árido)

Cromínea, GO (Ledru et al., 2001 - Longa fase seca)

Salitre, MG (Alexandre et al., 1999; Turcq et al., 1997; Ledru, 1992 - fase fria e seca)

- Serra Negra, MG (De Oliveira, 1992 - Clima frio e seco, com savana e floresta)

Lagoa dos Olhos, MG (De Oliveira, 1992 - Clima seco, início de resfriamento)

Morro de Itapeva, SP (Behling, 1998 - Frio com certa umidade, floresta araucária)

Rio Tamanduá, São Simão, SP (Turcq et al., 1997 -floresta aberta e muita precipitação)

Campo Formoso, BA (este trabalho - Floresta, clima úmido) 
Figura 41 - Mapa paleoclimático da América do Sul há 14.000 anos (17.000 anos calibrado).

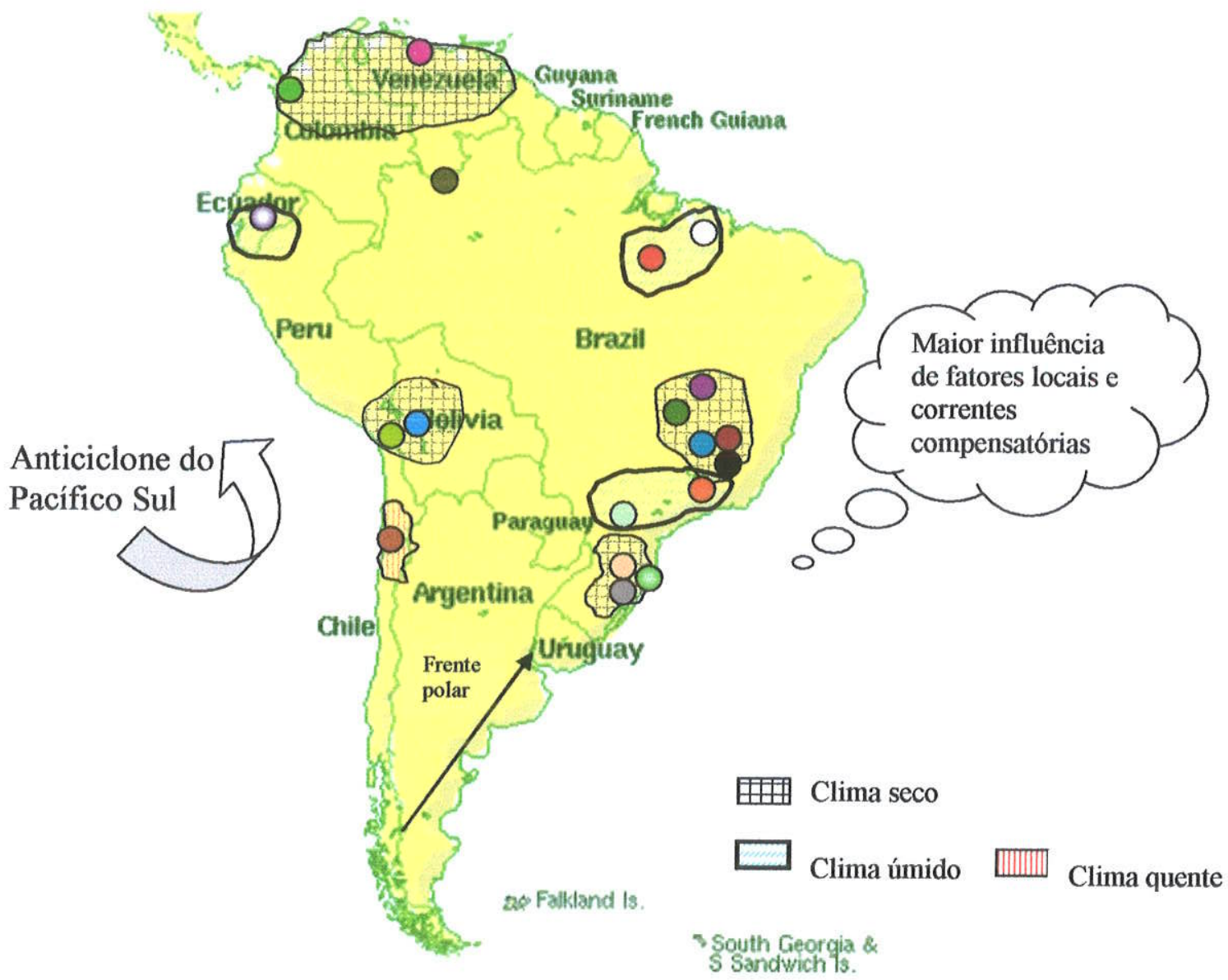

Região dos Lagos do Chile (Ashcuorth \& Hoganson, 1993 - Ambiente quente)

Rio Rastro e Morro da Igreja, SC (Behling, 1998 - Geadas, florestas e campos)

Boa Vista, SC (Behling, 1998 - Frio e seco, floresta e campos)

Botuverá, SC (Cruz-Júnior et al, no prelo - Seco entre 18.000 a 16.000 anos calibrados)

Norte dos Andes (Peru e Chile) (Coltrinari, 1993 - Período frio)

- Altiplano Boliviano (Sylvestre et al., 1999 - Lagos secos)

Lago Chorreras, Equador (Hansen et al., 2003 - Frio e mais úmido que o atual)

- Lago Jotaordó, Colômbia (Berrio et al., 2000 - Clima mais frio e seco. Florestas)

Lago Valência, Venezuela (Leyden, 1985 - Aumento da umidade, savana e árvores)

Lagoa da Pata, AM (Colinvaux \& De Oliveira, 2001 - Aquecimento)

Carajás, AM (Colinvaux \& De Oliveira, 2001 - Aumento dos elementos arbóreos)

Lagoa do Caço, MA (Ledru et al., 2001 - Clima úmido, cerrado)

Águas Emendadas, DF (Barberi- Ribeiro, 1994; Barberi et al., 2000 - Semi árido)

Cromínea, GO (Ledru et al., 2001 - Longa fase seca)

Lagoa Santa, MG (Prous, 1992; Parizzi et al., 1998 - Clima mais seco que o atual)

Salitre, MG (Alexandre et al., 1999; Turcq et al., 1997; Ledru, 1992 - Fase fria e seca)

Serra Negra, MG (De Oliveira, 1992 - Savana, floresta sazonal e floresta de galeria)

Morro de Itapeva, SP (Behling, 1997b; 1998 - Frio com certa umidade, floresta araucária)

Rio Tamanduá, São Simão, SP (Turcq et al., 1997 - Floresta aberta e muita precipitação) 
Figura 42 - Mapa paleoclimático da América do Sul há 12.000 anos (14.000 anos calibrado).

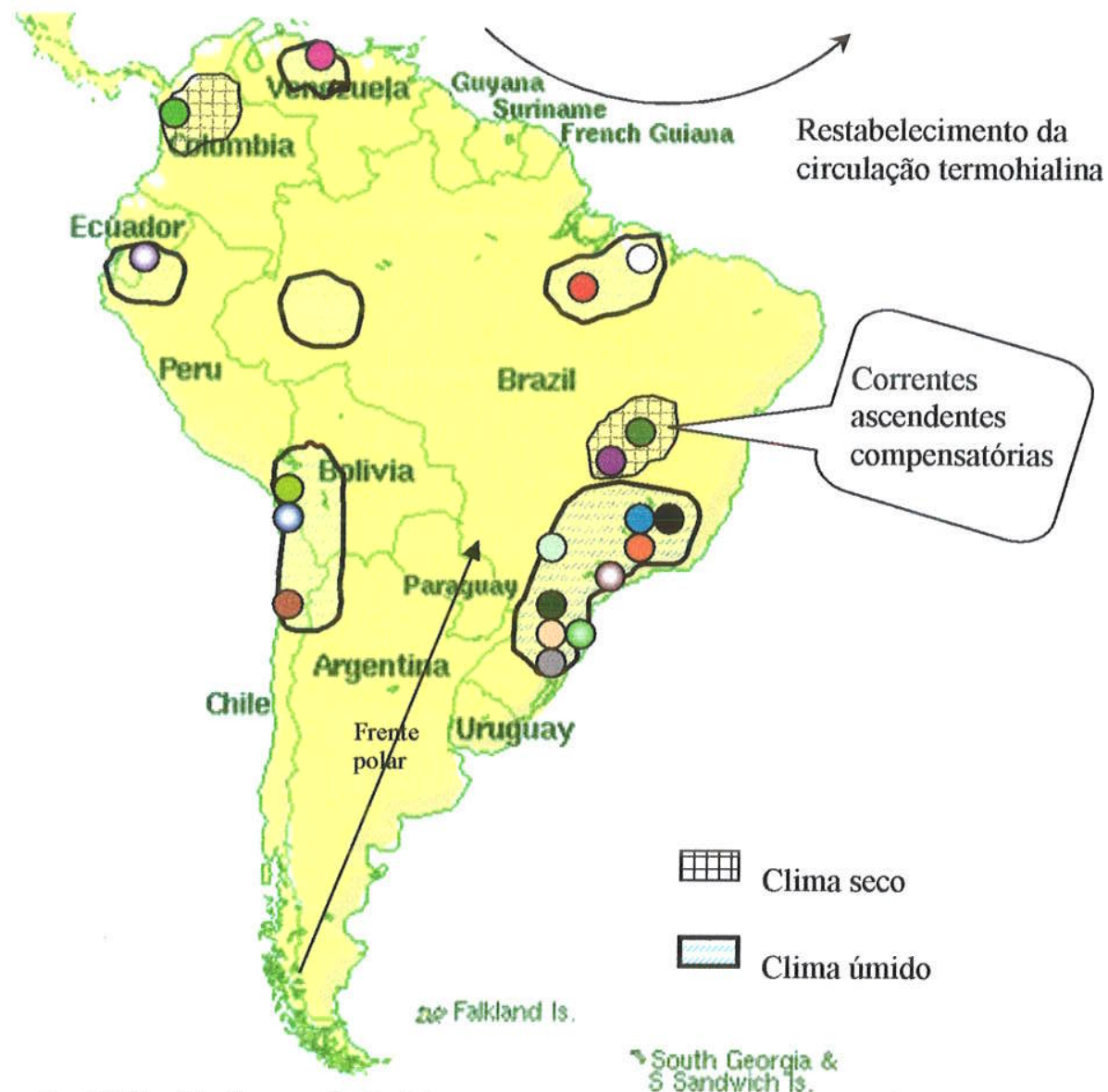

- Região dos Lagos do Chile (Ashcuorth \& Hoganson, 1993 - Florestas úmidas)

O Cordilheira Domeyko, Chile (Latorre et al., 2003 - Úmido entre 13.500 e 9.700)

Rio Rastro e Morro da Igreja, SC (Behling, 1998 - Geadas. Florestas e campos)

O Boa Vista, SC (Behling, 1998 - Frio e seco, floresta e campos)

O Botuverá, SC (Cruz-Júnior, no prelo - Úmido entre 15.000 e 14.000 anos calibrados)

Serra dos Campos Gerais, SC (Behling, 1997a; 1998 - Úmido e frio com fortes geadas)

O Norte dos Andes (Peru e Chile) (Coltrinari, 1993 - Período frio)

Humaitá, AM (Gouveia et al., 1997 - Condições úmidas com floresta)

Lago Chorreras, Equador (Hansen et al., 2003 - Frio e mais úmido que o atual)

Lago Jotaordó, Colômbia (Berrio et al., 2000 - Transição para clima mais frio e seco)

Lago Valência, Venezuela (Leyden, 1985 - Aumento da umidade, savana e árvores)

Carajás, AM (Colinvaux \& De Oliveira, 2001 - Aumento dos elementos arbóreos)

Lago do Caço, MA (Ledru et al., 2001 - Frio e úmido)

- Cromínea, GO (Ledru et al., 2001 - Longa fase seca)

- Águas Emendadas, DF (Barberi- Ribeiro, 1994; Barberi et al., 2000 - Semi árido)

- Serra Negra, MG (De Oliveira, 1992 - Savana, floresta sazonal e floresta de galeria)

- Salitre, MG (Ledru, 1992 - Ausência da estação seca)

8 Morro de Itapeva,SP (Behling, 1997b; 1998 - Frio com certa umidade, floresta araucária)

0 Vale do Ribeira, SP (Cruz-Júnior et al, no prelo - Úmido de 16.000 e 14.000 anos cal.)

○ Rio Tamanduá, São Simão, SP (Turcq et al., 1997 - Muita precipitação) 
Figura 43 - Mapa paleoclimático da América do Sul há 10.000 anos (11.500 anos calibrados).

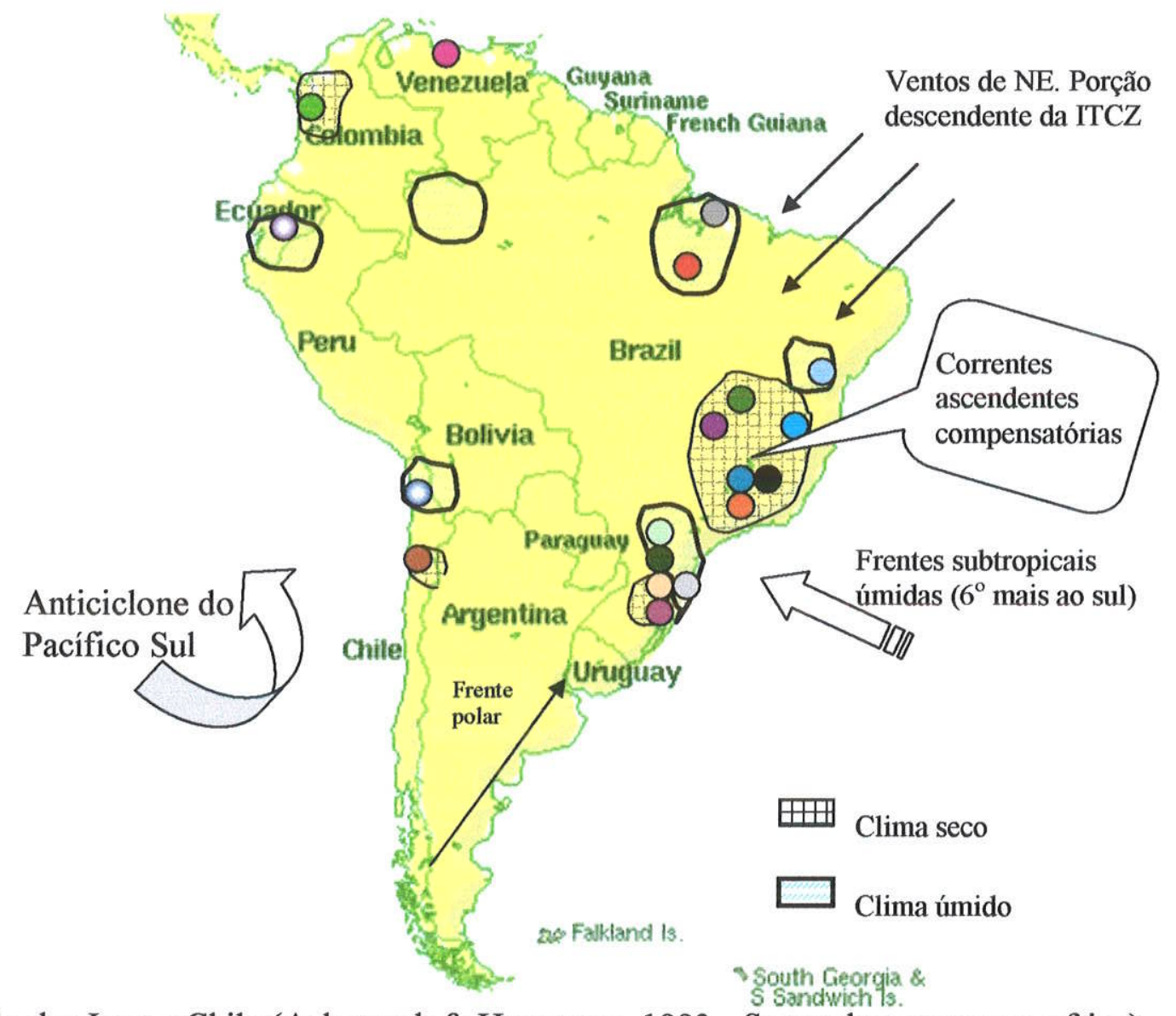

Região dos Lagos Chile (Ashcuorth \& Hoganson, 1993 - Sazonalmente secos e frios)

O Cordilheira Domeyko, Chile (Latorre et al., 2003 - Úmido entre 13.500 e 9.700)

- Aparados da Serra, RS (Roth \& Lorscheltter, 1991 - Semi-árido, baixas temperaturas)

Boa Vista, SC (Behling, 1998 - Frio e seco, floresta de campos)

O Poço Grande, SC (Behling, 1998 - Floresta atlântica e floresta tropical)

- Serra de Campos Gerais, SC (Behling, 1997a; 1998 - Úmido e frio com fortes geadas)

O Lago Chorreras, Equador (Hansen et al., 2003 - Aquecimento e sazonalidade moderada)

Lago Jotaordó, Colômbia (Berrio et al., 2000 - Clima mais frio e seco. Savanas herbáceas)

- Lago Valencia (Salgado-Labouriau, 1980; Leyden, 1985 - Maior umidade, savana e árvores)

○ Lagoa do Curuçá, PA (Behling 1998 - Floresta fechada e densa com alguns Podocarpus)

- Carajás, PA (Colinvaux \& De Oliveira, 2001 - Máximo desenvolvimento de florestas)

- Cromínea, GO (Ledru et al., 2001 - Longa fase seca)

- Águas Emendadas, DF (Barberi- Ribeiro, 1994; Barberi et al., 2000 - Semi árido.)

L Lago do Pires, MG (Behling, 1995b; 1998 - Baixa precipitação)

- Salitre, MG (Ledru, 1996 - Ausência da estação seca)

Serra Negra, MG (De Oliveira, 1992 - Savana, floresta sazonal e floresta de galeria)

Morro de Itapeva, SP (Behling, 1997; 1998 - Frio com certa umidade, floresta araucária)

Rio Tamanduá, São Simão, SP (Turcq et al., 1997 - Muita precipitação)

Campo Formoso e norte da Bahia (Este trabalho - floresta e clima úmido; De Oliveira et al., 1999 - Densa floresta com espécies atlânticas) 
Figura 44 - Mapa paleoclimático da América do Sul há 8.000 anos (9.000 anos calibrados).

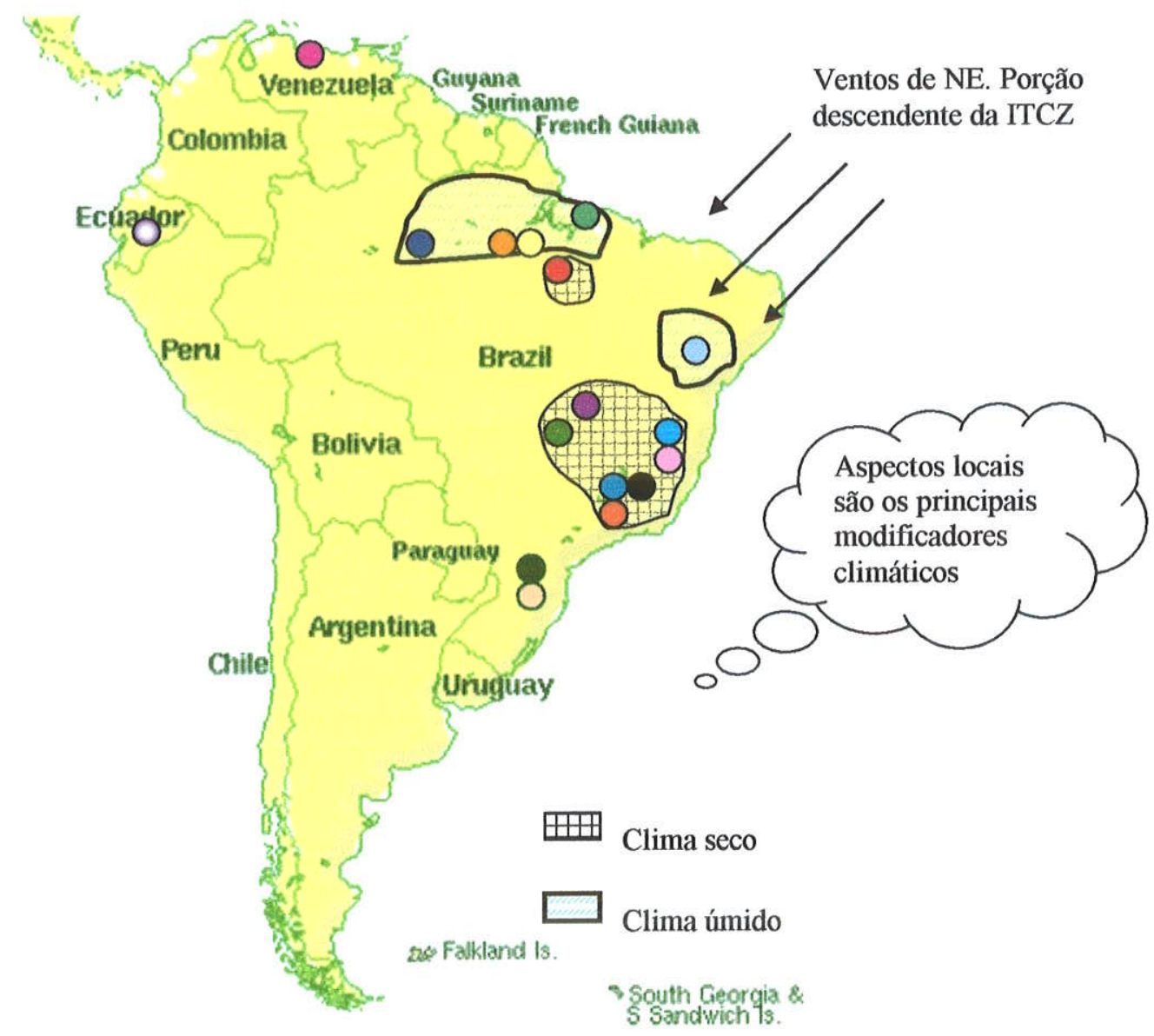

Serra de Campos Gerais, SC (Behling, 1997a; 1998 - Úmido, frio com fortes geadas)

0 Boa Vista, SC (Behling, 1998 - Frio e seco, floresta e campos)

O Lago Chorreras, Equador (Hansen et al., 2003 - Sazonalidade moderada)

- Lago Valencia, Venzuela (Leyden, 1985 - Quente. Úmido nas encostas, seco no planalto)

Lago Calado, AM (Behling et al., 2001 - Floresta de várzea, igapó, floresta aberta)

Lago Crispin, PA (Behling \& Costa, 2001 - Floresta amazônica)

- Lagos Geral e Comprida, PA (Bush et al., 2000 - Precipitação aumenta a partir de 8.800)

Rio Curuá, PA (Behling \& Costa, 2000 - Presença de buritizal)

8 Carajás, PA (Colinvaux \& De Oliveira, 2001 - Período seco)

Águas Emendadas, DF (Barberi- Ribeiro, 1994; Barberi et al., 2000 - Semi árido)

- Cromínea, GO (Ledru et al., 2001 - Longa fase seca)

- Lago do Pires, MG (Behling, 1995b; 1998 - Fase úmida)

Lago Dom Helvécio, MG (Turcq, 2001 - Clima seco com rebaixamento do lago)

- Serra Negra, MG (De Oliveira, 1992 - Savana, floresta sazonal e floresta de galeria)

Salitre, MG (Ledru, 1992 - Clima frio)

Morro de Itapeva, SP (Behling, 1997b; 1998 - Floresta seca de montanha)

- Norte da Bahia (De Oliveira et al., 1999 - Clima quente e úmido aumento de cerrado) 
As pesquisas limnológicas no Lago Caracarană, Roraima $\left(3^{\circ} 51^{\prime} \mathrm{N}, 59^{\circ} 48^{\prime} \mathrm{W}\right)$ mostram que este lago registra menor nivel entre 9.000 e 7.500 anos (não calibrado). Quando comparado com outros estudos limnológicos, como os realizados no Lago Dom Helvécio, MG $\left(19^{\circ} 40^{\prime} \mathrm{S}, 42^{\circ} 35^{\prime} \mathrm{W}\right)$, pode-se notar algumas semelhanças, pois os dados indicaram que o Lago Dom Helvécio estava 22 metros abaixo do seu nível atual a 8.200 anos (não calibrado) e 13 metros abaixo do seu nível atual a 5.000 anos (não calibrado), confirmando clima mais seco na região sudeste. Entretanto, como o Lago Caracaranã já se encontra no Hemisfério Norte, embora ainda bem próximo ao equador, não pode ter sua fase seca explicada por menor insolação de verão, explicação geralmente fornecida pelos autores que trabalham com o sudeste brasileiro (Simões-Filho, 2000). Os estudos palinológicos no médio São Francisco indicam período mais úmido entre 11.000 e 6.800 anos (não calibrado) (De Oliveira et al., 1999). O aumento de precipitação no nordeste também não pode ser explicado por diferenças no padrão de insolação (Turcq et al., 2002).

O mesmo conjunto de dados pode conduzir a diferentes interpretações paleoclimáticas, dependendo da explicação sugerida para o evento. Regiöes próximas podem ser interpretadas com climas variados, conforme pode ser observado nas figuras 37 a 44 (páginas 171 a 178), mas torna-se dificil concluir se a questão é paleoclimática ou de interpretação de dados.

A variação sazonal da posição da ITCZ pode mudar dependendo da posição da SACZ nas latitudes médias. A interconexão dessas duas zonas de convergência regula as estações e a precipitação na porção norte do nordeste (Ledru et al., 2006). Os dados paleoclimáticos do sudeste brasileiro mostram clima mais seco no Holoceno Inferior e Médio (10.000 a 4.000) que indicaria atividade mais fraca da SACZ. Este enfraquecimento é provavelmente ligado à insolação mais fraca no verão, porque sua formação depende da troca de calor e da intensa atividade convectiva na Amazônia. O clima mais úmido, observado no médio São Francisco durante o Holoceno Inferior a Médio, poderia corresponder à posição mais ao sul da ITCZ no Oceano Atlântico no verão, e o clima mais seco no norte de Roraima poderia estar relacionado à posição mais ao norte da ITCZ no inverno.

9.5 - Situações paleoclimáticas no Nordeste Brasileiro e suas relações com a caatinga.

A paleoecologia da caatinga é fundamental para testar hipóteses biogeográficas como as possiveis conexões com as vegetações amazônica e atlântica e também para compreender o resfriamento tropical citado nos trabalhos palinológicos. A vegetação da caatinga também pode auxiliar na compreensão dos efeitos climáticos possivelmente relacionados aos fenômenos ENSO (sensu Kousky et al., 1984) e de deslocamento da ITCZ. 
O número de endemismos na floresta costeira do Brasil, assim como disjunções com a Amazônia, são evidências da estabilidade da floresta costeira brasileira. Em relação ao Nordeste Brasileiro, pode-se analisar os refúgios contemporâneos. A floresta é atualmente persistente em algumas encostas com maior umidade, a temperatura é menor que em outras regiōes circundadas pela caatinga. Essas manchas de florestas denominadas brejos, são consideradas como refúgios atuais. A composição florística com muitas espécies amazônicas sugere que sejam remanescentes de florestas e não produtos de interferências antrópicas. Os brejos também exibem espécies do complexo atlântico, indicando que são interessantes reliquias com mistura de espécies (Prance, 1982).

As evidências botânicas são baseadas em centros de endemismo e distribuição dișunta e, em menor extensão, em adaptações xerófitas de plantas de florestas chuvosas e na variação dos padrões de espécies polimórficas. São ainda pouco estudadas as possibilidades de cada área representar refúgios de diferentes vegetações de forma a acumular espécies de cada época de refúgio, um processo denominado "padrão de distribuição multiestratificado". O Brasil precisa de maior quantidade de amostragens das diferentes vegetações para a efetuação desse tipo de trabalho, uma vez que podem ocorrer centros de endemismos edáficos, que não apresentam relação com mudanças climáticas (Prance, 1982).

As interpretações paleoclimáticas no Nordeste Brasileiro durante a última glaciação constituem grande desafio. Suas características climáticas atuais ainda são pouco conhecidas e diferentes regimes pluviométricos podem ser identificados. No norte do Nordeste, a principal época de chuva é de março a abril; no sul, a chuva ocorre de dezembro a fevereiro; e no leste do Nordeste, chove de maio a julho. A variação espacial da precipitação anual também é alta. Enquanto porções do interior recebem menos que 600 milimetros, a costa leste recebe em torno de 2.000 milimetros por ano (Rao et al., 1993). A precipitação média sobre o Nordeste e sua variabilidade interanual constituem importantes desafios a serem resolvidos pela meteorologia tropical. Devido à localização geográfica, esperar-se-ia a precipitação típica das áreas tropicais. Entretanto, a precipitação média da região, que é imediatamente vizinha à maior floresta tropical do mundo, é muito menor que a média equatorial (Moura \& Shukla, 1982).

A correlação entre a anomalia quente na superficie do Oceano Atlântico em março com a precipitação, pode ser explicada pelo aumento do fluxo convergente úmido devido aos ventos de sudeste que se direcionam para o Nordeste, aumentando a precipitação. Por outro lado, menores temperaturas superficiais no oceano teriam o efeito contrário. $O$ aumento da precipitação produz convecções mais profundas na ITCZ com movimento ascendente no norte e descendente sobre o Nordeste e região oceânica nas proximidades. Uma possível razão para não encontrar correlações 
negativas amplas com a região Norte pode ser a natureza dinàmica do relacionamento entre a anomalia da temperatura superficial dos oceanos e a precipitação. Enquanto temperaturas superficiais quentes no oceano produzem uma ITCZ intensa e associada ao movimento descendente sobre o Nordeste, temperaturas superficiais frias não necessariamente induzem movimentação. Desse modo, a correlação é bem mais forte em relação aos eventos de seca que aos periodos úmidos (Moura \& Shukla, 1982).

Em alguns aspectos, o Oceano Atlântico tropical é similar ao leste do Pacifico tropical, em relação, por exemplo, a temperatura superficial logo ao sul do Equador (estreita faixa de água fria) e nos ventos que originam a ITCZ. A ITCZ e esta faixa de temperaturas frias possuem ciclo anual mais proeminente no Atlântico, do mesmo modo que a ENSO é mais proeminente no Pacífico. Estudos sugerem que a variabilidade na precipitação no Nordeste Brasileiro e na região centroocidental da África está intimamente relacionada a variações no gradiente da temperatura superficial do oceano ao longo do equador. A precipitação no Brasil tende a estar mais fortemente relacionada com o dipolo da temperatura superficial atlântica que com o El Niño do Pacífico (Chang et al., 1997).

A quantidade de precipitação recebida pela área costeira do Nordeste Brasileiro também está relacionada com os ventos de sul. Atualmente, o máximo de precipitação ocorre durante o inverno austral, quando as correntes de vento ganham o máximo de intensidade e massas úmidas de ar atingem as montanhas costeiras (Arz et al., 1999).

Os períodos glaciais exibem contrastes climáticos acentuados em relação aos interglaciais. É bem conhecido mundialmente que o padrão de climas mais secos durante o máximo glacial é freqüentemente interrompido por áreas com aumento pluviométrico.

O Nordeste apresenta várias características sugestivas de clima pretérito mais úmido, como vales fluviais meandrantes atualmente secos, terraços fluviais indicativos de rios de alto gradiente, precipitação química em cavernas indicando infiltrações generalizadas, tufos calcários fossilíferos e horizontes calcíticos em solos (Auler, 2000).

Outro fator atuante no Nordeste Brasileiro seria um tipo de circulação Walker entre a América do Sul e o Atlântico Sul, entre os meses de dezembro e fevereiro, que também seria afetado pela ENSO, ficando mais fraco durante eventos El Niño (Kousky et al., 1984).

Conforme comentado anteriormente, as modificações dos padrões de circulação oceânica alteram os padrões atmosféricos, como por exemplo o posicionamento da ITCZ, que culmina em aumento da precipitação sobre o Nordeste Brasileiro enquanto que outras áreas no Brasil experimentaram condições glaciais mais secas que as atuais. 
O aumento da umidade associado a baixas temperaturas, permitiria a expansão de rica floresta galeria, que, segundo De Oliveira et al (1999) poderia ser o meio pelo qual teria ocorrido intercàmbio florístico entre as regiŏes amazônica e atlântica.

O presente estudo demonstrou que, pelo menos na porção norte da Bahia, a Caatinga propriamente dita não estava presente do último máximo glacial até o início da deglaciação, muito embora algumas de suas espécies tenham resistido às mudanças climáticas. Por outro lado, foi possivel sugerir aumento de precipitação conforme comentado no capítulo anterior. Segundo discussão anterior, os eventos Heinrich não teriam promovido alterações na sazonalidade da precipitação, embora possa ter ocorrido aumento na quantidade da precipitação (Jennerjahn et al., 2004). O registro espeleológico da Toca da Boa Vista, na região de Campo Formoso, também parece sugerir sazonalidade na precipitação (Auler \& Smart, 2001). A vegetação, não fornece dados que permitam inferir a duração da estação seca e conseqüentemente não há como determinar alterações ou não na sazonalidade da precipitação.

Ocorreram flutuações de até 2 metros no nível da água na Toca da Boa Vista, em resposta a sazonalidade da precipitação. Os depósitos parecem representar dois eventos episódicos.

Não há indícios de intercâmbios florísticos entre o complexo vegetacional atlântico e amazônico como proposto por De Oliveira el al. (1999), embora seja provável que tal intercâmbio possa ter ocorrido mais ao norte, visto que o registro polínico é de caráter regional.

Os tufos calcários exibem importantes depósitos de macrofitofósseis, muitos deles em excelentes condições de preservação além de registros de fósseis de animais. Tufos calcários podem ser datados pelo método U/Th e por isso vem sendo bastante estudados em diversas regiões do mundo,

O Brasil possui importantes depósitos de tufos inativos como os situados no centro e norte da Bahia (Auler, 1999), Russas no Ceará (Duarte \& Nogueira, 1980), Umbuzeiro na Paraiba (Muniz \& Ramirez, 1971; Duarte, 1979; Duarte \& Vasconcelos, 1980) e o da Serra das Araras em Mato Grosso (Almeida, 1945). Os depósitos ativos estão situados principalmente na região da Serra da Bodoquena, MS (Boggiani \& Coimbra, 1995; Boggiani et al., 1999).

O estudo mais detalhado destes depósitos em conjunto, poderia contribuir para melhor compreensão das mudanças climáticas e vegetacionais do Quaternário. 
10 - Consideraçoes finais

O presente trabalho procurou caracterizar o registro fitofossilifero de tufos calcários situados no municipio de Campo Formoso, norte da Bahia. Realizaram-se três análises independentes para melhor controle dos resultados, evitando-se raciocínio circular. Embora as três análises tenham utilizado diretamente os fitofósseis, cada análise utiliza dados isoladamente. A tafonômica costuma permitir interpretações ambientais como sub-ambientes deposicionais e mesmo aspectos climáticos. A taxonômica envolve o reconhecimento sistemático do registro fóssil, gerando lista floristica que possa ser comparada a outras listas florísticas, visando, a identificação da vegetação presente na regrão. A análise taxonômica dificilmente permite o reconhecimento da estrutura da vegetação, embora possa sugerir vegetaçăo mais ou menos arbórea; o registro fóssil de espécies herbáceas normalmente é bastante limitado. A análise fisionômica não requer a identificação taxonômica dos espécimes fósseis, apenas o reconhecimento de quantas morfoespécies estariam presentes na associação. Este tipo de análise pode permitir o reconhecimento da estrutura vegetacional, assim como de alguns parâmetros climáticos como pluviosidade. A deposição de tufos calcários requer água em abundância, mesmo que sazonalmente

Através da análise tafonômica foi possível observar que:

a) há poucas semelhanças dos tufos fósseis brasileiros com os depósitos de tufos calcários quaternários da Europa, mas foram possiveis comparações tafonômicas com os depósitos atuais da região de Bonito, MS

b) os fitofósseis indicam ter sofrido pouco transporte, motivado, em parte, pela rápida precipitação do calcário. Este pequeno transporte é importante por permitir a caracterização de uma assembléia fóssil proveniente de uma mesma região

c) foi possivel o reconhecimento de dois sub-ambientes deposicionais: o de alta turbulência, preservando camadas laminadas mais compactas e espessas de carbonato, normalmente associadas às folhas fósseis e o de menor turbulência, com a ocorrência de calcário poroso, semelhante à deposição de fibras de aragonita e de mais sedimentos. Condições intermediárias entre estes dois sub-ambientes parecem sugerir condições variáveis sazonalmente, principalmente porque essas diferenças ocorrem num mesmo afloramento 
d) ocorrem pequenas variações na deposição entre os três afloramentos estudados, havendo alguns indicios de que o afloramento Salgadinho estivesse sujeito a condiçŏes mais frias, mas os dados são poucos para permitir interpretação segura.

A análise taxonômica gerou uma lista floristica bem diversificáda:

a) foram descritos 69 morfotipos, sendo reconhecidos taxonomicamente 49 morfotipos, 44 a nivel de espécie, distribuidos em 37 gêneros e 26 familias.

b) quinze espécies puderam ser identificadas com grau de incerteza baixo ou muito baixo e foram usadas preferencialmente em algumas análises

c) nove espécies foram identificadas com o grau de incerteza entre baixo e moderado, quatorze com grau moderado de incerteza e duas com grau alto de incerteza. A maior incerteza na identificação foi causada, tanto pelo tipo de preservação do espécime, quanto devido à sua fragmentação, principalmente se o morfotipo é composto por apenas um espécime, mas algumas vezes a incerteza na identificação foi causada pela grande diversidade da família estudada ou pela ocorrência do mesmo padrão de nervação em diferentes famílias.

d) foram registradas cinco espécies de Annonaceae e Euphorbiaceae, quatro espécies de Malvaceae e Lamiaceae, três espécies de Begoniaceae, duas espécies de Bignoniaceae, Chrysobalanaceae, Elaeocarpaceae, Malpighiaceae e Sterculiaceae, além de uma espécie de Apocynaceae, Aquifoliaceae, Boraginaceae, Campanulaceae, Cecropiaceae, Celastraceae, Connaraceae, Dilleniaceae, Guttiferae (-Clusiaceae), Olacaceae, Phytolacaceae, Piperaceae, Rhamnaceae, Rosaceae, Rutaceae e Tiliaceae, independente do grau de incerteza na identificação

e) foi possível observar a preservação de alguns elementos herbáceos, incluindo quatro tipos de monocotiledôneas que não puderam ser identificados.

f) não foi observada diferença vegetacional significativa entre os diferentes sub-ambientes ou entre os três afloramentos, muito embora haja diferenças na composição das espécies em cada ponto.

g) pode-se verificar mistura vegetacional, com espécies de ampla distribuição geográfica e espécies típicas da caatinga e cerrado. O cerrado teria avançado vindo de oeste. Pode ainda ter havido migração de elementos das florestas estacionais presentes na encosta da Chapada Diamantina, principalmente aquelas que preferem ambientes úmidos.

h) A mistura de floras parece indicar a melhor distribuição das chuvas e/ou aumento na precipitação anual. Mais especificamente, corresponderia a uma "descida" aproximada de cerca de 300 a 400 metros de altitude e um aumento de 300 a 700 milimetros de chuva por ano, visto que Campo 
Formoso encontra-se entre 400 e 800 metros de altitude e apresenta precipitação atual entre 300 a 500 milimetros por ano.

i) a ausência de Myrtaceae poderia sugerir a pequena relevância das espécies mais tipicamente atlànticas na assembléia fóssil.

j) năo há indícios de formação de corredores vegetacionais conectando o complexo vegetacional atlântico com a vegetação amazônica, pelo menos não no norte da Bahia

A análise fisionômica fornece informações adicionais relacionadas à estrutura vegetacional da assembléia fóssil:

a) após a necessidade de se obter os padrões físionômicos específicos para a região da Bahia, constatou-se que a fisionomia foliar não permite por si só o reconhecimento dos diferentes biomas presentes na Bahia.

b) pode-se concluir que a vegetação de caatinga não segue os padrões físionômicos internacionais por se tratar de vegetação decídua em área tropical. Desse modo, suas folhas estão adaptadas somente ao período das chuvas, visto não haver folhas no periodo seco. Em regiões com maior umidade, a vegetação é mais densa, e parte dos espécimes não perdem as folhas no período seco, fazendo com que, paradoxalmente, folhas menores se conservem no registro fossilifero, enquanto que normalmente, vegetações fechadas possuem folhas maiores que as correspondentes em área aberta devido à menor luminosidade.

c) pode-se interpretar que a fisionomia da assembléia fóssil assemelha-se a vegetações presentes em maiores altitudes atualmente, indicativas de vegetação de dossel fechado.

d) a assembléia fóssil estaria sujeita a condições sazonalmente mais úmidas, mas próximas às condições atualmente presentes na região de cerrado.

Considerando-se os mapas paleoclimáticos propostos, verifica-se a possibilidade de condições climáticas relativamente distintas em regiões próximas, seja por questões meramente locais seja por compensações nas correntes atmosféricas, que transportam umidade de uma região para outra. Deste modo não se pode generalizar a maior umidade presente no norte da Bahia com o restante do nordeste. Outros depósitos de macrofitofósseis deveriam ser mais bem estudados, inclusive com dados cronológicos, para aperfeiçoar os conhecimentos paleoclimáticos das últimas fases de sedimentação do Quaternário. 
ABBOTT, M.B.: SELTZER, G.O.; KELTS, K.R. \& SOUTHON, J. (1997) - Holocene palcohydrology of the Tropical Andes from lake records. Quaternary Research, 47: 70-80.

ABSY, M.L; CLEEF, A.; FOURNIER, M.; MARTIN, L.; SERVANT, M.: SIFEDDINE, A.: FERREIRASILVA, M.: SOUBIES, F.: SUGUIO, K.; TURCQ, B. \& VAN DER HAMMEN, T. (1991) - Mise en évidence de quatre phases d'ouverture de la forêt dense dans le sud-est de l'Amazonie au cours des 60.000 dernières années. Première comparaison avec dautres regions tropicales. Comphu Rendens Academie de Sciencie, série II, 312:673-678

ALCOFORADO-FILHO, F.G.; SAMPAIO, E.V.S.B. \& RODAL, M.J.N. (2003) - Florística e fitossociologia de um remanescente de vegetação caducifólia espinhosa arbórea em Caruaru, Pernanbuco. Acia botânica brasilica, 17(2): 267-303.

ALEXANDRE, A.; MEUNIER, J.D.; MARIOTTI, A. \& SOUBIES, F. (1999) - Late Holocene phytolith and carbon-isotope record from a latosol at Salitre, South-Central Brazil. Quaternary Research, 51: 187194.

AMBRIZZI, T; SOUZA, E.B.; PULWARTY, R.S. (2004) - The Hadley and Walker regional circulations and associated Enso impacts on South America seasonal rainfall. In: DIAZ, H.F. \& BRADLEY, R.S. (2004) (eds.) The Hadley circulation: present, past and future. Dordrecht Klumer Academic Publisher. Pp. 203-235.

ANDRADE, L.A.Z; FELFILI, J.M. \& VIOLATTI, L. (2002) - Fitossociologia de uma área de cerrado denso na RECOR-IBGE, Brasília, DF. Acta botanica brasilica, 16(2): 225-240.

ARAÚJO, E.L.; SAMPAIO, E.V.S.B. \& RODAL, M.J. (1995) - Composição florística e fitossociológica de três áreas de caatinga de Pernambuco. Revista brasileira de Biologia, 55(4): 595-607.

ARAÚJO, G.M.; BARBOSA, A.A.A.; ARANTES, A.A. \& AMARAL, A.F. (2002) - Composição floristica de veredas no municipio de Uberlândia, MG. Revista brasileira de botânica, 25(4): 475-493.

ARZ, H.W.: PÄTZOLD, J. \& WEFER, G. (1999) - The deglacial history of the western tropical Atlantic as inferred from high resolution stable isotope records off northeastern Brazil. Larth and Planetary Science Letters, 167: 105-117.

ASHWORTH, \& HOGANSON (1993) - The magnitude and rapidity of the climate change marking the end of the Pleistocene in the mid-latitude of South America. Palaeogeography. Palaeoclimatology. Palaeoecology, 101(3/4): 263-270.

AULER, A.S. (1999) - Karst evolution and palacoclimate of eastern Brazil. Ph.D. thesis. University of Bristol.

AULER, A.S. (2000) - O clima no nordeste do Brasil durante o periodo glacial. O Carste, 12(3): 150-15 l.

AULER, A.S. \& SMART, P.L. (2001) - Late Quaternary palcoclimate in semiarid Northeastern Brazil from U-series dating of travertine and water-table speleothems. Qucternary Research, 55: 159-167.

AXEROLD, D.I. \& BAILEY, H.P. (1969) - Paleotemperature analysis of Tertiary floras. Palaeogeography. Palaeoclimatology, Palaeoecology, 6: 163-195.

BAILEY, I.W. \& SINNOTT, E.W. (1915) - A botanical index of Cretaceous and Tertiary climates. Science, 41: $831-834$.

BAILEY, I.W. \& SINNOTT, E.W. (1916) - The climatic distribution of certain types of angiosperm leaves. American Journal of Botany, 3: 24-39.

BARBERI RIBEIRO, M. (1994) - Paleovegetação e paleoclima no Quaternário Tardio da Vereda de Águas Emendadas, DF. Dissertação de Mestrado. Universidade de Brasília.

BARBERI, M.; SALGADO-LABOURIAU, M.L. \& SUGUIO, K. (2000) - Paleovegetation and paleoclimate of "Verada de Águas Emendadas", central Brazil. Journal of South American Earth Sciences, 13: 241-254.

BARREIRA, S.; SCOLFORO, J.R.S.; BOTELHO, S.A. \& MELLO, J.M. (2002) - Estudo da estrutura da regeneração natural e da vegetação adulta de um cerrado senso stricto para fins de manejo florestal. Scientia forestalis, 61: 64-78.

BARREIRO, M.; CHANG, P.\& SARAVANAN, R. (2002) - Variability of the South Atlantic Convergence Zone simulated by na atmospheric general circulation model. Journal of Climate, 15: 745-763. 
BARRETO. A.MF: PESSENDA. L.C.R. \& SUGUIO. K. (1996) - Probable dricr Holocene climate evidenced by charcoal bearing miadle São Francisco tiver paleodunes. State of Bahlia. Brazil. Anais de Academia brasileira de Ciencias, 68(Supl.): $43-48$.

BARROSO, G.M. (199la) - Sistemática de Angiospermas do Brasil. Vol. 2. Editora da Universiade Federal de Viçosa. 377 p.

BARROSO, G.M. (1991b) - Sistemática de Angiospermas do Brasil. Vol. 3. Editora da Universiade Federal de Viçosa. $326 \mathrm{p}$.

BARROSO, G.M: PEIXOTO, A.L.: ICHASO, C.L: GUIMARĂES, E.F. \& COSTA, C.G. (2002) Sistemática de Angiospermas do Brasil. Vol. 1. Segunda edição. Editora da Universiade Federal de Viçosa. 309p.

BECK W.J.: RÉCY, J. TAYLOR, F.; EDWARDS, R.L.\& CABIOCH, G. (1997) - Abrupt change in early Holocene tropical sea surface temperature derived from coral records. Nanure, 385: 705-707.

BEHLNG, H. (1995) - A high resolution Holocene pollen record from Lago do Pires, SE Brazil: vegetation. climate and fire history. Journal of Paleolimnology, 14: 253-268

BEHLING, H. (1997a) - Late Quaternary vegetation, climate and fire history of the Araucaria forest and campos region from Serra Campos Gerais, Parana State (South Brazil). Review of Palaeobolany and Palynology, 97(1/2): 109 121

BEHLING, H. (1997b) - Late Quaternary vegetation, climate and fire history from the tropical mountain region of Morro de Itapeva, SE, Brazil. Palaeogeography. Palaeoclimalology. Palaeoecology, 129. 407.422 .

BEHLING, H. (1998) - Late Quaternary vegetational and climatic changes in Brazil. Review of Palaeobotany and Palynology, 99: 143-156.

BEHLING, H. \& COSTA, M.L. (2000) - Holocene environmental changes from the Rio Curua record in the Caxiuanã Region, eastern Amazon Basin. Quaternary Research, 53: 369-377.

BEHLING, H. \& COSTA, M.L. (2001) - Holocene vegetational and coastal environmental changes from the Lago Crispim record from northeastern Pará State, eastern Amazonia. Review of Palacobotany and Palynology, 114: 145-155.

BEHLING, H. \& HOOGHIEMSTRA, H. (1998) - Late Quaternary palaccology and palacoclimatology from pollen records of the savannas of the Llanos Orientales in Colombia. Palaeogeography. Palaeoclimatology. Palaeoecology, 139: 251-267.

BEHLING, H. \& HOOGHIEMSTRA, H. (2000) - Holocene rain forest-savana dynamics and climatic implications: high resolution pollen record Laguna Loma Linda in eastern Colombia. Joutnal of Quaternary Science, 15: 469-477.

BEHLING, H. \& LICHTE, M. (1997) - Evidence of dry and cold climatic conditions at glacial times in tropical Southeastern Brazil. Quaternary Research, 48: 348-358.

BEHLING, H; KEIM, G.; IRION, G.; JUNK, W. \& MELLO, JN. (2001) - Holocene environmental changes in the Central Amazon Basin inferred from Lago Calado (Brazil). Palaeogeography: Palaeoclimatology, Palaeoecology, 173(1/2): 87-101

BENCKE, C.S.C. \& MORELLATO, L.P.C. (2002) - Estudo comparativo da fenologia de nove espécies arbóreas em três tipos de floresta atlântica no sudeste do Brasil. Revista brasileira de Botânica, 25(2): 237-248.

BERRIO, J.C.; HOOGHIEMSTRA, H. BEHLING, H. \& VAN DER BORG, K. (2000) - Late Holocenc history of savanna gallery forest from Carimagua area, Colombia. Review of Palaeobotany and Palynology, 111: 295-308.

BOGGIANI, P.C. \& COIMBRA, A.M. (1995) - Quaternary limestones of the Pantanal Área, Brazil. Anais da Academia brasileira de Ciências, 67(3): 343-349.

BOGGIANI, P.C.; COIMBRA, A.M.; GESICKI, A.L.D.; SIAL, A.N.; FERREIRA, V.P.; RIBEIRO, F.B. \& FLEXOR, J.M. (2000) - Tufas calcárias da Serra da Bodoquena. In: SCHOBBENHAUS, C.: CAMPOS, D.: QUEIROZ, ET.; WINGE, M. \& BERBERT-BORN, M. (2000) Sítios geológicos c palcontológicos do Brasil. Gilges-UNESCO.Brasilia, DF, v. 1, p. 249-259

BROECKER, W.S. (2000) - Abrupt climate change: causal constraints provided by the paleoclimate record. Earth-Science Reviews, 51: 137-154.

BROECKER, W.S. \& HEMMING, S. (2001) - Climate swings come into focus. Science, 294:2308-2309.

BUSH, A.B.G. \& PHILANDER, G.H. (1998) - The role of ocean-atmosphere interactions in tropical cooling during the Last Glacial Maximum. Science, 279: 1341-1344. 
BUSH. M.B.: MLLLE, M.C: DE OLIVEIRA. P.E. \& COLINVAUX. P.A. (2000) - Two histories of cnvironmental change and human disturbance in castern lowtand Amazonia. The Holocene. 10. 5435.53.

CABRAL, R. (2000) - O estado do meio ambiente no Brasil. In CieoBrasil 2000 - Perspectivas do meio ambiente no Brasil. Disponivel em: www.ambientebrasil.com.br

CARNEIRO-FILHO, A. (1993) - Cerrados amazônicos: fósseis vivos? Algumas reflexões. Re'vista li, 14 : $63-68$.

CARVALHO, D.A: OLIVEIRA-FILHO, A.T: VILELA, E.A. \& GAVILANES, M.L. (1995a) - Estrutua fitossociológica de mata ripária do alto Rio Grande (Bom Sucesso, estado de Minas Gerais). Revisia brasileira de Botânica, 18(1): 39-49.

CARVALHO, D.A: OLIVEIRA-FILHO, A.T: VILELA, E.A. \& GAVILANES, M.L. (1995b) - Flora arbustivo-arbórca de uma floresta ripária no alto Rio Grande em Bom Sucesso/MG. Acla bolânica brasilica, 9(2): $231-245$.

CARVALHO, D.A.; OLIVEIRA-FILHO, A.T.; VILELA, E.A. \& CURI, N. (2000) - Florística e estrutura da vegetação arbórea de um fragmento de floresta semidecidual às margens do reservatório da usina hidrelétrica Dona Rita (Itambé do Mato Dentro, MG). Acta botânica brasilica, 14(1): 37-55.

CARVALHO, L.M.V.; JONES, C. \& LIEMANN, B. (2004) - The South Atlantic Convergence Zone: intensity, form, persistence, and relationships with intraseasonal to interannual activity and extreme rainfall. Joumal of Climate, 17: 88-108.

CHANG, P.; JI, L. \& LI, H. (1997) - A decadal climate variation in the tropical Atlantic Ocean from thermodynamic air-sea interactions. Nature, 385: 516-518.

CHIANG, J.C.H. \& KOUTAVAS, A. (2004) - Tropical flip-flop connections. Nature, 432: 684-685

CHRISTOPHEL, D.C. \& BLACKBURN, D.T. (1978) - Tertiary megafossil flora of Maslin Bay, South Australia: a preliminary report. Alcheringa, 2: 311-319.

CHRISTOPHEL, D.C. \& GREENWOOD, D.R. (1989) - Changes in climate vegetation in Australia during the Tertiary. Review of Palaeobotany and Palynology, 58(2-4): 95-109.

COLINVAUX, P.A. \& DE OLIVEIRA, P.E. (2001) Amazon plant divcrsity and climate through the Cenozoic. Palaeogeography, Palaeoclimatology, Palaeoecology, 166: $51-63$

COLTRINARI, L. (1993) - Global Quaternary changes in South America. Global and Planetary Change, 7 : $11-23$.

COSTA, A.A. \& ARAÚJO, G.M. (2001) - Comparação da vegetação arbórea de cerradão e de cerrado na Reserva do Panga, Uberlândia. Minas Gerais. Acta botânica brasilica, 15(1): 63-72.

COSTA, I.R.: ARAÚJO, F.S. \& LIMA-VERDE, L.W. (2004) - Flora e aspectos auto-ecológicos de um encrave de cerrado na chapada do Araripe, Nordeste do Brasil. Acta botânica brasilica, 18(4): 759-770.

CRISTALLI, P.S. (1997) - Tafoflora das camadas Nova Iorque, depósitos neógenos do rio Parnaiba. Municipio de Nova lorque (MA), Brasil. Dissertação de Mestrado. Instituto de Geociências da Universidade de São Paulo.

CRUZ-JUNIOR, F.W.; BURNS, S; KARMANN, I; SHARP, W; VUILLE, M; CARDOSO, A.O. FERRARI, J.A.; DIAS, P.L.S. \& VIANA-JÚNIOR, O (2005) - Insolation-driven changes in atmospheric circulation over the past $116 \mathrm{ky}$ in subtropical Brazil. Nature, 434: 63-66.

DAJOZ, R. (1983) - Ecologia Geral. Editora Vozes. 472p.

DE OLIVEIRA, P.E. (1992) - A palynological record of late Quaternary vegetational and climatic change in southeastern Brazil. Ph.D.. Ohio State University

DE OLIVEIRA, P.E.; BARRETO, A.M.F. \& SUGUIO, K. (1999) - Late Pleistocene/Holocene climatic and vegetational history of the Brazilian caatinga: the fossil dunes of the middle São Francisco River. Palaeogeography, Palaeoclimatology, Palaeoecology, 152: 319-337.

DESJARDINS, T; CARNEIRO-FILHO, A.; MARIOTTI, A.; CHAUVEL, A. \& GIRARDIN, C. (1996) Changes of the Forest-savanna boundary in Brazilian Amazônia during the Holocene revealed by stable isotope ratios of soil organic carbon. Oecologia, 108: 749-756.

DOLPH, G.E. \& DILCHER, D.L. (1979) - Foliar physiognomy as an aid in determining paleoclimate. Palaeontographica, Abt. B. 170: 151-172.

DOLPH, G.E. \& DILCHER, D.L. (1980) - Variation in leaf size with respect to climate in the Tropics of the Western Hemisphere. Bulletin Torrey Botanical Club, 107: 29-34.

DORF, E. (1964) - The Use of Fossil Plants in Palacoclimatic Interpretations. In: NAIRN, A.E.M. (Editor), Problems in Palaeoclimatology. Interscience, London, pp 13-31. 
DUARTE. L. (1979) - Sobre uma Filicinca (lastrea dardanoi n.sp.) do Quaternário do Estado da Paraiba. Anais da Academia brasileira de Ciencias, $51(4): 741-746$.

DUARTE L. \& NOGUEIRA, M.I.M. (1980) - Vegetais do Quaternário do Brasil I - Flónula de Russas, CE. Anais da Academia brasileira de Ciencias, 52(1): 37-48.

DUARTE L \& VASCONCELOS, M.F.C. (1980) - Vegctais do Quaternário do Brasil. Il - Flórula do Umbuzciro, PB. Anais da Academia brasileira de Ciências, 52(1): 93-108.

FERGUSON D.K. (1985) - The origin of leaf-assemblages - new light on an old problem. Review of Palaeobotany and Palynology 46: 117-188.

FERRAZ. E.M.N.: RODAL, M.J.N.; SAMPAIO, E.V.S.B. \& PEREIRA, R.C.A. (1998) - Composição florística em trechos de vegetação de caatinga e brejo de altitude na região do Vale do Pajcú, Pernambuco. Revista brasileira de Bolânica, 21(1): 7-15.

FERRAZ-VICENTINI, K.R. \& SALGADO-LABOURIAU, M. (1996) - Palynological analysis of a palm swamp in Central Brazil. Journal of South America larth Sciences, 9(3/4): $207-219$.

FERRI, M.G. (1980) - Vegetação brasileira. Editora da Universidade de São Paulo. 157p.

FIDELIS, A.T \& GODOY, S.A.P. (2003) - Estrutura de um cerrado strico sensu na glaba cerrado pé-degigante, Santa Rita do Passa Quatro, SP. Acta botânica brasilica, 17(4): 531-539.

FIGUEIREDO, L.S.; RODAL, M.J.N. \& MELO, A.L. (2000) - Floristica e fitossociologia de uma área de vegetação arbustiva caducifólia espinhosa no município de Buíque, Pernambuco. Naturalia, 25: 205 224.

FELFILI, J.M.: NOGUEIRA, P.E.; SILVA JR., M.C.; MARIMON, B.S. \& DELITTI, W.B.C. (2002) Composição floristica e fitossociologia do cerrado sentido restrito no município de Água Boa - MT. Acta botânica brasilica, 16(1): 103-112.

FONSECA, M. R. \& BRAZIL, T.K. (2004) - Caracterização de Ambientes. Disponível em www.ufba.br' $\sim$ qualibio/txt 010 html.

FORD, T.D. \& PEDLEY, H.M. (1996) - A review of tufa and travertine deposits of the world. Earth-Science Reviews, 41: 117-175

FOREST, CE.: WOLFE, J.A.; MOLNAR, P. \& EMANUEL, K.A. (1999) - Palcoaltimetry incorporating atmospheric physics and botanical estimative of paleoclimate. Bulletin of Geology Sociey of America, 111(4): 497-511.

FORNARI, M.; RISACHER, F. \& FÉRAUD, G. (200l) - Dating of palcolakes in the central Altiplano of Bolivia. Palaeogeography, Palaeoclimatology. Palaeoecology, 172: 269-282.

FUNDAÇÃO RIO CIPÓ (2006) - Disponivel em http://www.serradocipo.com/ Acessado em 15/01/06

GAN, M.A.; KOUSKY, V.E. \& ROPELEWSKI, C.F. (2004) - The South America monsoon circulation and its relationship to rainfall over West-Central Brazil. Journal of Climate, 17: 47-66.

GANOPOLSKI, A.: RAHMSTORF, S.; PETOUKHOV, V. \& CLAUSSEN, M. (1998) - Simulation of modern and glacial climates with a coupled global model of intermediate complexity. Nature, 391: 351 356.

GIULIETT, A.M; PIRANI, J.P. \& HARLEY, R.M. (1997) - Espinhaço range region eastern Brazil. Cambriedge: World Wide Fund for Nature/ World Conservation Union. P. 397-404. In: DABIS, S.D.: HEYWOOD, V.H.; HERRERA-MacBRYDE, O; VILLA-LOBOS, J. \& HAMILTION, A.C. (eds.) Centres of plants diversity: a guide and strategy for their conservation.

GOUDIE A.S.; VILES H.A. \& PENTECOST, A. (1993) - The late-Holocene tufa decline in Europe. The Holocene, 3(2): 181 186.

GOUVEIA, S.E.M.; PESSENDA, L.C.R.; ARAVENA, R.; BOULET, R.; ROVERATTI, R. \& GOMES, B.M. (1997) - Dinâmica de vegetações durante o Quaternário recente no sul do Amazonas, indicada pelos isótopos do carbono $\left({ }^{12} \mathrm{C},{ }^{13} \mathrm{C},{ }^{14} \mathrm{C}\right)$ do solo. Ceochimica Brasiliensis, 11(3): $355-367$.

GREENWOOD D.R. (1991) - The taphonomy of plant macrofossils In: S.K. DONOVAN (editor) The Process of Fossilization. Columbia University Press, New York 141-169p.

GREENWOOD, D.R. (1992) - Taphonomic constraints on foliar physiognomic interpretations of Late Cretaceous and Tertiary palaeoclimates. Review of Palacobotany and Palynology, 71: 149-190.

GUILDERSON, T.P.; FAIRBANKS, R.G. \& RUBENSTONE, J.L. (1994) -.. Tropical temperature variations since 20,000 years ago: modulating interhemispheric climate change. Science, 263: 663-665.

HABERLE, S.G. \& MASLIN, M.A. (1999) - Late Quatemary vegetation and climate change in the Amazon Basin on a 50,000 year pollen record from the Amazon Fan, ODP Site 932. Quaternary Research. $51(1): 27-38$ 
HANSEN. B.C.S: RODBELL. D.T.: SELTZER, G.O : LEON, B.: YOUNG, K.R \& ABBOTT, M. (2003) Late-glacial and Holocene vegetational history from two sites in the western Cordilheira of southwesten Ecuador. Palaeogeography. Palaeoclimatology. Palaeoecology, 194: 79-108.

HEUSSER. C.J. (1981) - Palynology of the Last Interglacial - Glacial cycle in midlatitudes of Southern Chile. Onatemary Research, 16:293-321.

HEUSSER, C.J. (1989) - Southern Westerlies during the Last Glacial Maximum. Letter to the editor Ouatemary Research, 31(3): 423-425.

HICKEY, L.J. (1973) - Classification of the architecture of dicotyledonous leaves. American Jounal of Bolany 60(1): 17-33.

HOOGHEMSTRA, H. (1989) - Quaternary and Upper-Pliocene glaciations and forest development in the tropical Andes: evidence from a long high-resolution pollen record from the sedimentary basin of Bogotá, Colombia. Palaeogeography, Palaeoclimatology. Palaeoecology, 72: 11-26.

HOLL, C.; ZONNEVELD, K.Z.F. \& WILLEMS, H. (2000) - Organic-walled dinoflagellates cyst assemblages in the tropical Atlantic Ocean and oceanographical changes over the last $140 \mathrm{ka}$. Palaeogeography, Palaeoclimatology, Palaeoecology, 160(1/2): 69-90.

HOWARD, R.A. (1969) - The ccology of an elfin forest in Puerto Rico, 8. Studies on stem growth and form and leaf structure. Journal of the Arnold Arboretum, 50(2): 225-262.

HUECK, K. (1972) - As florestas da América do Sul. Ecologia, composição e importância cconômica. Editora Universidade de Brasilia / Editora Polígono S.A. 466p.

HULTON, N.; SUGDEN, D.: PAYNE, A. \& CLAPPERTON, C. (1994) - Glacier modeling and the climate of Patagonia during the last glacial maximum. Quaternary Research, 42: $1-19$.

IBGE (1977) - Geografia do Brasil.

IMAÑA-ENCINAS, J.; PAULA, J.E. \& SUGIMOTO, N. (1995) - Análise fitossociológica do cerrado da Fazenda Marflora. Revista Pesquisa Agropecuária brasileira, 30(5): 577-582.

IRIONDO, M.H. (1999) - Climatic changes in the South American plains: records of a continent-scale oscillation. Quaternary International, 57/58: 93-112.

IRIONDO, M.H. \& GARCIA, N.O. (1993) - Climatic variations in the Argentine plains during the last 18,000 vears. Palaeogeography. Palaeoclimatology, Palaeoecology, 101: 209-220.

JANSSEN A; SWENNEN R.; PODOOR N. \& KEPPENS E. (1999) - Biological and diagenetic influence in Recent and fossil tufa deposits from Belgium. Sedimentary Geology, 126: 75--95.

IENNERJAHN, T.C.: TTTEKKOT, V.; ARZ, H.W.; BEHLING, H.; PÄTZOLD, J.\& WEFER, G. (2004) Asynchronous terrestrial and marine signals of climate change during Heimrich events. Science, 306 : 2236-2239.

JOLY, A.B. (1998) - Introdução à Sistemática Vegetal. Companhia Editora Nacional.

JONES, C. \& CARVALHO, L.M.V (2002) - Active and break phases in the South America monsoon system. Journal of Climate, 15: 905-914.

KOUSKY, V.E.; KAGABI, M.T. \& CAVALCANTI, I.F.A. (1984) - A review of the Southern Oscillation: oceanic-atmospheric circulation changes and related rainfall anomalics. Telliss, 36A: 49()-504

KUHLMANN, E. (1977) - A vegetação In: Geografia do Brasil-Região Nordeste, vol. 2. IBGE. 85-110.

LATORRE, C; BETANCOURT, J.L.; RYLANDER, K.A.; QUADE, J. \& MATTHEI, O. (2003) - A vegetation history from the arid prepuna of northern Chile $\left(22-23^{\circ} \mathrm{S}\right)$ over the last 13500 years. Palaeogeography, Palaeoclimatology, Palaeoecology, 194: 223-246.

LEDRU, M.P. (1992) - Modifications de la végétation du Brésil Central entre la dernière époque glaciaire et 1 interglaciaire actuel. Comptu Rendeus Academie de Sciencie, série II, 314: 117-123.

LEDRU, M.P. (1993) - Late Quatemary environmental and climatic changes in Central Brazil. Quaternary Research, 39: 90-98.

LEDRU, M.P.; BRAGA, P.I.S.; SOURBIS, F.; FOURMIER, M.; MARTIN, L.; SUGUIO, K. \& TURCQ, B. (1996) - The last 50.000 years in the Ncotropics (Southern Brazil): evolution of vegetation and climate. Palaeogeography, Palaeoclimatology. Palaeoecology, 123: 239-257. LEDRU, M.P.; BERTAUX, J. \& SIFEDDINE, A. (1998) - Absence of last glacial maximum records in
lowland tropical forest. Quaternary Research, 49:223-237.

LEDRU, M.P.; CORDEIRO, R.C.; DOMINGUEZ, J.M.L; MARTIN, L; MOURGUIART, P.; SIFEDDINE, A. \& TURCQ, B. (2001) - Latc-Glacial cooling in Amazonia inferred from pollen at Lagoa do Caçó, Northem Brazil. Quaternary Research, 55: 47-56. 
LEDRU, M.P: CECCANTINI G: GOUVEIA, SEM: LOPEZSAEZ, JA: PESSENDA. L.CR \& RIBEIRO. A.S. (2066) - Millenial-scale climatic and vegetation changes in a northem Cerrado (Northeast. Brazil) sinec the Last Glacial Maximum. Onaternary Science Reviews, in press

LEMOS, J.R. \& ROOAL. M.J.N. (2002) - Fitossociologia do compononte lenhoso de um trecho da vegetação de caatinga no Parque Nacional Serra da Capivara. Piauí, Brasil. Acta botanica brasilica.
16(1): $23-42$.

LEYDEN, B.W. (1985) - Late Quaternary aridity and Holocene moisture fluctuations in the Lake Valencia Basin, Venczucla. Ecology 66(4): 1279-1295. LIU, K.B. \& COLINVAUX. P.A. (1985) - A 5200-year history of Amazon rain forest. Joumal of
Biogeography, 15: 231-248.

LOPES, W.P.: SILVA, A.F.: SOUZA. A.L. \& MEIRA-NETO, J.A.A. (2002) - Estrutura fitossociológica de um trecho de vegetação arbórea no Parque Estadual do Rio Doce -. Minas Gerais, Brasil. Acta botanica
brasilica. 16(4): 443-456.

LORENZI, H. (1992) - Árvores brasileiras: Mamual de identificação e cultivo de plantas arbóreas nativas do Brasil. Instituto Plantarum. 352p.

LORSCHEITTER, M.L; TURCQ, B. \& RICCOMINI, C. (1990) - Palinologia de sedimentos paludosos do Colônia, São Paulo, Brasil. Paleobotânica Latinoamericana, $9(1): 27$

MARTIN, L.: FOURNIER, M.: MOURGUIART, P; SIFEDDINE, A; TURCQ, B; ABSY, M.L. \& FLEXOR, J.M. (1993) - Southern Oscillation signal in South American palacoclimatic data of the last
7000 years. Quatemary Research, 39(3): 338-346.

MASS, P.J.M; KAMMER, H.M.: JUNIKKA, L.: MELLO-SILVA, R. \& RAINER, H. (2001) - Annonnaceac from Central-eastern Brazil. Rodriguésia, 52(80): 65-98.

MAYLE, F.E. \& BEERLING, D.J. (2004) - Late Quaternary changes in Amazonian ecosystems and their implications for global carbon cycling. Palaeogeography. Palaeoclimatology, Palaeoecology $214: 11$ -

MEIRA-NETO, J.A.A. \& MARTINS, F.R. (2002) - Composição floristica de uma floresta estacional semidecidual montana no município de Viçosa, MG. Revista Arvore, 26(4): 437-446

MEIRA-NETO, J.A.A \& SAPORETTI Jr., A.W. (2002) - Parâmetros fitossociológicos de um cerrado no Parque Nacional da Serra do Cipó, MG. Revista Árvore, 26(5): 645-648.

MELO, E. (1999) - Levantamento da familia Polygonaceac no estado da Bahia. Brasil: espécies do scmiárido. Rodriguésia, 50(76/77): 29-47.

MERZ-PREIB, M. \& RIDING. R. (1999) - Cyanobacterial tufa calcification in two freshwater streams: ambient environment, chemical thresholds and biological proceses. Sedimentary Geology, 126: 103-124

MILNE, G.A.; LONG, A.J. \& BASSETT, S.E. (2005) - Modelling Holocene relative sea-level observations from the Caribean and South America. Quaternary Science Reviews, 24: 1183-1202

MORLEY, J.J. (1979) - A transfer function for estimating palcoceanographic conditions based on deep-sea surface sediment distribution of radiolarian assemblages in the South Atlantic. Quarternary Research,
12: $381-395$. MORNER, N.A. (1993) - Global change: the high-amplitude changes 13-10 ka ago-novel aspects. Global
and Planetary Change, 7: 243-250.

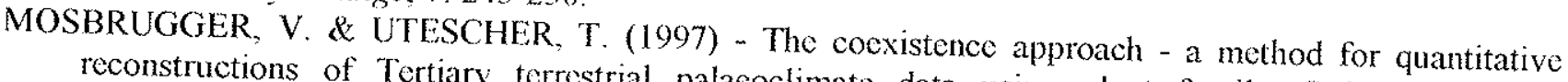
reconstructions of Tertiary terrestrial palacoclimate data using plant fossils. Palaeogeography.
Palaeoclimatology. Palaeoecology, 134:61-86.

MOURA A \& theory and numerical experiments sciences, 38: 2654-2674

MOUTON, J.A. (1966) - Les types biologiques foliai la Socité Botanique de France 113/Mémoires: 28-36 Raunkiaer. Etat actuel de la question. Bulletin de

MOUTON JA (1976) - L biométric du limbe: miso an Botanique de lirance 123(3-4): $145-158$. mise au point de nos connaissances. Bulletin de la Socité

MUNIZ, G.C.B. \& RAMÍREZ L O (1971) -

Paraiba c Pernambuco. Anais da Acodem - Tufo calcário (tufa) quaternário com moluscos nos estados da

NASCIMENTO CES. RODAl da Academia brasileira de Ciências, 43(Supl.): 611-618 remaining xerophytic woodland associated \& CAVALCANTI, A.C. (2003) - Phytosociology of the Francisco river - Petrolina. Pernambuco, Brato an environmental gradient at the banks of the São 
NIMER, E. (1989) - Climatologia do Brasil. IBGE. $421 \mathrm{p}$

NOBRE. P. \& SHUKLA, J. (1996) - Variations of sea surface temperature, wind stress and rainfall over the tropical Atlantic and South America. Joumal of Climate. 10(4): 2664-2679

OLIVEIRA-FILHO, A.T. \& MACHADO, J.N.M. (1993) - Composição florística de uma floresta semidecidua montana, na Serra de São José. Tiradentes, Minas Gerais. Acta boranica brasilica, 7(2): $71-88$.

OLIVEIRA-FILHO, A.T: ALMEIDA, R.J: MELLO, JM. \& GAVILANES, M.L. (1994) - Estrutura fitossociológica e variáveis ambientais $\mathrm{em}$ um trecho da mata ciliar do córego dos Vilas Boas, Reserva Biológica do Poço Bonito, Lavras, MG. Revista brasileira de Botânica, 17(1): 67 85.

ORTLIEB, L \& MACHARE, J. (1993) - Former EI Niño events: records from western South America. Global and Planetary Change, 7: 181-202.

PAEGLE, J.N. \& MO, K.C. (2002) - Linkages between summer rainfall variability over South America and sea surface temperature anomalies. Journal of Climate, 15(12): 1389-1407.

PAILLER, D. \& BARD, E. (2002) - High frequency palaeocenographic changes during the past 140.000 yx recorded by the organic matter in sediments of the Iberian Margin. Palaeogeography. Palaeoclimatology. Palaeoecology, 279: 1-22.

PARIZZI, M.G. (1993) - Dinâmica da Lagoa Santa com base em estudos palinológicos, geomorfológicos c geológicos de sua bacia. Dissertação de Mestrado. Instituto de Geociências da Universidade Federal de Minas Gerais.

PARIZZI, M.G.; SALGADO-LABOURIAU, M.L. \& KOHLER, H.C. (1998) - Genesis and environmental history of Lagoa Santa, southeastern Brazil. The Holocene, 8(3): $311-321$.

PEDRALLI, G.; TEIXEIRA, M.C.B; FREITAS, V.L.O; MEYER, S.T. \& NUNES, Y.R.F. (2000) Florística e fitossociologia da estação ecológica do Tripui, Ouro Preto, MG. Ciência agrotécnica, 24 : $103-136$.

PEIXOTO, A.L. \& GENTRY, A. (1990) - Diversidade e composição floristica da mata de tabuleiro na Reserva florestal de Linhares(Espirito Santo, Brasil). Revista brasileira de botânica, 13: 19-25.

PENTECOST, A. (1993) - Bristish travertines: a review. Proc. Geol. Assoc., 104: 23-39)

PENTECOST, A. \& VILES, H. (1994) - A review and reassessment of travertine classification. Géographie Physique et Quaternaire, 48: 305-314.

PEREIRA, I.M.; ANDRADE, L.A.; BARBOSA, M.R.V. \& SAMPAIO, E.V.S.B. (2002) - Composição florística e análise fitossociológica do componente arbustivo-arbóreo de um remanescente florestal no agreste paraibano. Acta botânica brasilica, 16(3): 357-369.

PESSENDA, L.C.R.; GOMES, B.M.; ARAVENA, R,; RIBEIRO, A.S.; BOULET, R. \& GOUVEIA, S.E.M. (1998) - The carbon isotope record in soils along a forest-cerrado ecosystem transect: implications for vegetation changes in the Rondonia state, southwestern Brazilian Amazon region. The Holocene, 8(5): $631-635$.

PESSENDA, L.C.R; BOULET, R; ARAVENA, R; ROSOLEN, S.E.M.; RIBEIRO, A.S. \& LAMOTTE; M. (2001) - Origin and dynamics of soil organic matter and vegetation changes during the Holocene in a forest-savanna transition zone, Brasilian Amazon region. The Holocene, 11(2): 250-254.

PESSENDA, L.C.R.; LEDRU, M.P., GOUVEIA, S.E.M.; ARAVENA, R.; RIBEIRO, A.S.; BENDASSOLLI, J.A. \& BOULET, R. (2005) - Holocene palaeoenvironmental reconstruction in northeastern Brazil inferred from pollen, charcoal and carbon isotope records. The Holocene, 15(6): $812-820$

PETERSON, L.C.; HAUG, G.H.; HUGHEN, K.A. \& RÖHL, U. (2000) - Rapid changes in the hydrologic cycle of the tropical Atlantic during the Last Glacial. Science, 290: 1947-1951.

POLE, M. (1991) - A modified terminology for angiosperm leaf architecture. Journal of the Royal Society of New Zealand, 21(4): 297-312.

PONTES, A.F.; BARBOSA, M.R.V. \& MASS, P.J.M. (2004) - Flora Paraibana: Annonaceac Juss.. Acta botanica brasilica, 18(2): 281-293.

PRADO, D.E. (2003) - As Caatingas da América do Siul. In.: Leal, I.F.; Tabarelli, M. \& Silva, J.M.C. (2003) - Ecologia c conservação da Caatinga. Editora Universitária da UFPE.

PRADO, D.E. \& GIBBS, P.E. (1993) - Patterns of species distributions in the dry seasonal forests of South America. Annals of the Missouri Botanical Garden, 80(4): 902-927.

PRANCE, G.T. (1982) - A review of the phytogcographic cvidences for Pleistocene climate changes in the neotropics. Annais of Missouri Botanical Garden, 69: 594-624. 
PROUS, 1992 - Arqueolegia Brasileira. Editora Universidade de Brasilia. 605p.

RABASSA. J. \& CLAPPERTON. C.M. (1990) - Quaternary glaciations of the Southern Andes. Quaternary Science Reviews: 9: $153-174$.

RADAMBRASIL (1979) - Texto explicativo da Folha SC-24

RAO, V.B. \& HADA. K. (1990) - Characteristics of rainfall over Brazil: Annual variations and connections with the Southern Oscillation. Theor. Appl. Climatol, 42: 81-91.

RAO. V.B.: LIMA M.C \& FRANCHITO. S.H. (1993) - Seasonal and interannual variations of rainfall over Eastern Northeast Brazil. Journal of Climate, 6: 1754-1763.1

RAO, V.B.: CAVALCANTI, I.R.F.A. \& HADA. K. (1996) - Annual variation of rainfall over Brazil and water vapor characteristics over South America. Journal of Geophysical Resarch, 101(D21): 26.53926.551

RAU G.H. (1976) - Dispersal of terrestrial plant litter into a subalpine lake. Oikos, 27(1): 153-160.

RAUNKIAER, C. (1934) - The life-forms of plants and statistical plant geography. Oxford University Press.

RICH F.J. (1989) - Review of Palaeobotany and Palynology, 58: 33-46.

RICCOMINI, C.; TURCQ, B.; MARTIN, L.; MOREIRA, M.Z. \& LORSHETTER, M.L. (1991) - The Colônia astrobleme, Brazil. Revista Brasileira do Instituto Geológico, 12: 9-25

RIZZINI, C.T. (1997) - Tratado de fitogeografia do Brasil. Aspectos ecológicos, sociológicos e florísticos. Âmbito Cultural Edições Ltda. 747 p.

ROCHA, C.C.; FRANCA-ROCHA, W. \& CHAVES, J.M. (2004) - Caracterização de unidades de paisagem utilizando avaliação ecológica rápida como suporte ao mapeamento da biodiversidade da Chapada Diamantina - BA. X Simpósio brasileiro de geografia física aplicada. Disponivel em http://geografia.igeo.uerj.br/xsbgfa/cdrom/cixo3/3.3/106/106.htm

RODAL, M.J.N. \& NASCIMENTO, L.M. (2002) - Levantamento florístico da floresta serrana da reserva biológica de Serra Negra, microrregião de Itaparica, Pernambuco, Brasil. Acta botânica bras, 16(4): $481-500$.

RODAL, M.J.N; ANDRADE, K.V.A.; SALES, M.F. \& GOMES, A.P.S. (1998) - Fitossociologia do componente lenhoso de um refúgio vegetacional no municipio de Buíque, Pernambuco. Revista brasileira de Biologia, 58(3): 517-526.

RODRIGUES, L. A. \& ARAÚJO, G. M. 1997. Levantamento florístico de uma mata decídua em Uberlândia, Minas Gerais, Brasil. Acta Botanica Brasilica, 11(2): 229-236.

RODRIGUES, L.A.; CARVALHO, D.A.; OLIVEIRA-FILHO, A.T.; BOTREL, R.T. \& SIL.VA, E.A. (2003) - Floristica e estrutura da comunidade arbórea de um fragmento florestal em Luminárias, MG. Acta bolanica brasilica, 17(1): 71-87.

ROTH, L. \& LORSCHELTTER, M.L. (1991) - Palynology of a peat in Parque Nacional de Aparados da Serra, Rio Grande do Sul, Brazil. Boletim do IG-USP. Publ. Esp., 8: 153-157.

RUBIOLLI, E. (1996) - $11^{\circ}$ Expedição à Toca da Boa Vista. O Carste, 8(2): 35-39.

RUBIOLLI, E. (2000) - História da exploração da maior caverna do Brasil. O Carste, 12(3): 103- 147.

RUBIOLLI, E \& PILÓ, (1995) - Arredores da Toca da Boa Vista. O Carste, 7(1): 15-21.

SALGADO-LABOURIAU, M.L. (1980) - A pollen diagram of the Pleistocene-Holocene boundary of Lake Valencia, Venezuela. Review of Palaeobotany and Palynology, 30: 297-312.

SALGADO-LABOURIAU, M.L.; CASSETI, V.; FERRAZ-VICENTINI, K.R.; MARTIN, L.; SOUBIÈS, F.: SUGUIO, K. \& TURQ, B. (1997) - Late Quaternary vegetational and climatic changes in cerrado and palm swamp from Central Brazil. Palaeogeography. Palaeoclimatology, Palaeoecology, 128: 215-226.

SALGADO-LABOURIAU, M.L.; BARBERI, M.; FERRAZ-VICENTINI, K.R. \& PARIZZI, M.G. (1998) A dry climatic event during the Late Quaternary of tropical Brazil. Review of Palaeobotany and Palynology, 99: 115-129.

SALLUN-FLLHO, W. (2005) - Geomorfologia e geoespeleologia do carte da Serra da Bodoquena, MS. Tese de doutoramento. Instituto de Geociências da Universidade de São Paulo. 196p.

SANTOS, A. S. R. (2004) - Programa Ambiental: A Última Arca de Noé. Disponivel em www aultimaarcadenoe.com/flora3.htm

SAPORETTI Jr, A.W; MEIRA-NETO, J.A.A. \& ALMADO, R.P. (2003) - Fitossociologia de cerrado sensu stricto no município de Abacté, MG. Revista Árvore, 27(3): 413-419.

SCHUltZ, A. (1990) - Introdução à Botânica Sistemática. Vol. 2. Editora da Universidade Federal do Rio Grande do Sul.

SEl, 2005 - Disponivel na internet em www sei.ba.gov.br 
SELTZER. G.O.: RODBELL D.T.: BAKER. P.A.: FRITZ, S.C. TAPIA P.M.: ROWE H.D. \& DUNBAR. R.B. (2002) - Early warming of tropical South Amcrica at the Last Glacial-hterglacial transition. Sicience. 296: $1685-1686$.

SERVANT. M.; FOURNIER. M.: SOUBIES. F.: SUGUIO. K. \& TURCQ, B. (1989) - Sécheresse holocène au Brésil (18-20" latitude Sud). Implications palćomćtćorologiques. Compru Rendeus Academie de Sciencié séric II. 309: 153-156

SIMÕES-FHLHO. 2000

SILVA. L.A. \& SCARIOT, A. (2003) - Composição floristica e estrutura da comunidade arbórea em uma floresta estacional decidual em aftoramento calcário (Fazenda São José, São Domingos. GO, Bacia do Rio Paraná). Acka botanica brasilica, $17(2): 305-313$.

SILVA, L.O; COSTA, D.A: SANTO FILHO, K.E: FERREIRA, H.D. \& BRANDÃO, D. (2002) Levantamento florístico e fítossociológico em duas áreas de cerrado sensu stricto no Parque Estadual da Serra de Caldas Novas, Goiás. Acta botânica brasilica, 16(1): 43-53.

SILVA, N.R.S; MARTINS, S.V; MEIRA-NETO, J.A.A. \& SOUZA, A.L. (2004) - Composição florística o estrutura de uma floresta estacional semidecidual montana em Viçosa, MG. Revista Árvore, 28(3): 397 405 .

SPICER, R.A. (1980) - The importance of depositional sorting to the biostratigraphy of plant megafossils. In: DILCHER, D.L. \& TAYLOR, T.N. (1980) Biostratigraphy of fossil plants - successional and paleoecological analysis. Dowden, Hutchinson \& Ross: 171-186.

SPICER, R.A. (1981) - The sorting and deposition of allochthonous plant material in a modern environment at Silwood Lake, Silwood Park, Bershire, England. U. S. Geological Survey Professional Paper 1143, $77 p$.

SPICER, R.A. (1989) - The formation and interpretation of plant fossil assemblages. Advances in Botanical Research, 16: 1-191

SPICER, R.A. (1991) - Plant taphonomic processes. In: ALLISON, P.A. \& BRIGGS. D.E. (1991) Taphonomy: Realeasing the Data Locked in the Fossil Record, Volume 9 of Topics in Geobiology, Plenum Press, New York.

STUTE, M: FORSTER, M.; FRISCHKORN, H.: SEREJO, A.; CLARK, J.F.: SCHLOSSER, P.; BROECKER, W.S. \& BONANI, G. (1995) - Cooling of tropical Brazil $\left(5^{\circ} \mathrm{C}\right)$ during the Last Glacial Maximum. Science, 269: 379-383.

SUGUIO, K. (1999) - Geologia do Quaternário - Mudanças ambientais: passado. presente. futuro. Paulo’s Editora. $366 \mathrm{p}$.

SYVESTRE, F.; SERVANT-VILDARY, S.; CAUSE, C.: FOURNIER, M. \& YBERT, J.P. (1999) - Lake level chronology on the Southern Bolivian Altiplano during Late-Glacial time and the Early Holocene. Quaternery Research, 51(1): 54-66.

THORNTHTHWAITE, C. \& MATHER, J. (1957) - Intructions and tables for computing potential evapotranspiration and water balance. Technological Drexel Institure. Climatological Laboratory. Climatologic Publication, 17: 231-615

TROVÃO, D.M.B.M; SILVA, S.C.; SILVA, A.B. \& VIEIRA-JÚNIOR, R.L. (2004) - Estudo comparativo entre três fisionomias de Caatinga no estado da Paraiba e análise do uso das espécies vegetais pelo homem nas áreas de estudo. Revista de Biologia e Ciências da Terra, 4(2)

TURCQ, B.; PRESSINOTTI, M.M.N. \& MARTIN, L. (1997) - Palcohydrology and paleoclimate of the past 33,000 years at the Tamanduá River, central Brazil. Quaternary Research, 47: 284-294.

TURCQ, B.; ALBUQUERQUE, R.C.A.L.S; BRACONNOT, P.; CORDEIRO, R.C. LEDRU, M.P.; SIFEDDINE, A; SILVA-DIAS, M.F.; SILVA-DIAS, P.L. \& SIMÕES-FILHO, F.F.L. (2001) Histórico da "monsão" sul americana e mecanismos climáticos associados. In: Múdanças globais e o Quaternário. Boletim de resumos do VIII Congresso da Associação Brasileira de Estudos do Quaternário (ABEQUA), Imbé, RS. 37-38.

UVO, C.B.; REPELLI, C.A.; ZEBIAK, S.E.\& KUSHNIR, Y. (1998) - The relationships between tropical Pacific and Atlantic SST and Northeast Brazil monthly precipitation. Journal of Climate, 11: 551-562.

VAN DER HAMMEN, T. \& ABSY, M.L. (1994) - Amazonia during the Last Glacial. Palaeogeography. Palaeoclimatology. Palaeoecology, 109: 247-261.

VAN GEEL, B.; HEUSSER, C.J.; RENSSEN, H. \& SCHUURMANS, C.J.E. (2000) - Climatic change in Chile at around $2700 \mathrm{BP}$ and global evidence for solar forcing: a hypothesis. The Holocene 10(5): 659.
664 . 
VELOSO, J.M.C. (1825-1829)-Florat Flumincnsis.

VELOSO, H.P.; RANGEL-FLLHO A.L.R. \& LIMA, J.C.A. (1991)-Classificação da vegetaçăo brasılcira. adaptada a un sistema universal. IBGE. Diretoria de Geociencias. Departamento de Recursos Naturais c. Estudos Ambicntais.

VIDAL, L: SCHNEIDER, R.R: MARCHAL, O.: BICKERT, T: STOCKER, T.F. \& WEFER. G. (1999) Link between the North and South Atlantic during the Heinrich events of the last glacial period ('limate Dynamics, 15:909-919.

VICTORIA, R.L: FRENANDES. F.: MARTINELLI, L.A: PICCOLO, M.C: CAMARGO. P.B. \& TRUMBORE, U. (1995) - Past vegetation change in the Brazilian Pantanal arboreal-grassy savanna ceotone by using carbon isotopes in the soil organic matter. Global Change Biology, 1: 165-171.

VILELA, E.A: OLIVEIRA-FILHO, A.T: CARVALHO, D.A. \& GAVLANES, M.L. (1995) - Fora arbustivo-arbórea de um fragmento de mata ciliar no alto Rio Grande, Itutinga, Minas Gerais. Acro botânica brasilica, 9(1): 87-100)

WAINER, l.; CLAUZET, G.; LEDRU, M.P.; BRADY, E. \& OTTO-BLLESNER, B. (2005) - Last glacial maximum in South America: Palcoclimate proxies and model results. Geophysical Research Letters, 32(8): L08702

WANG, X.; AULER, A.S.; EDWARDS, R.L.; CHENG, H.; CRISTALLI, P.S.; SMART, P.L.; RICHARDS. D.A. \& SHEN, C.C. (2004) - Wet periods in northeastern Brazil over the past $210 \mathrm{kyr}$ linked to distant climate anomalies. Nature, 432(7018): 740-743.

WASSON, R.J. \& CLAUSSEN, M. (2002) - Earth system models: a test using the mid-Holocene in the Southern Hemisphere. Ouaternary Science Reviews, 21: 819-824.

WEBB, L.J. (1959) - Physiognomic classification of Australian rain forest. Journal of Ecology, 47: $551-570$.

WELDEAB, S.; SCHNEIDER, R.R. \& KÖLLING, M. (2006) - Deglacial sea surface temperature and salinity increase in the western tropical Atlantic in synchrony with high latitude climate instabilities. Earth and Planetary Science Letters, 241: 699m 706

WEYL, P.K. (1978) - Micropaleontology and ocean surface climatc. Science, 202 (4367): 475-481

WILF, P.; WING, S.L.; GREENWOOD, D.R. \& GREENWOOD, C.L. (1998) - Using fossil leaves as paleoprecipitations indicators: An Eocene example. Geology. 26(3): 203-206

WOLFE, J.A. (1971) - Tertiary climatic fluctuations and methods of analysis of Tertiary floras Palacogeography, Palaeoclimatology. Palaeoecology: 9: 27-57

WOLFE, J.A. (1978) - A paleobotanical interpretation of Tertiary climates in the Northern Hemisphere American Scientist, 66: 694-703.

WOLFE, J.A. (1979) - Temperature parameters of humid to mesic forests of Eastern Asia and relation to forests of other regions of the Northern Hemisphere and Australasia. U. S. Geological Survey Professional Paper, 1106. 37p.

WOLFE, J.A. (1980) - Tertiary climates and floristic relationships at higher latitudes in the northern hemisphere. Palaeogeography. Palaeoclimatology. Palaeoecology: 30: 313-323.

WOLFE, J.A. (1985) - Distribution of major vegetational types during the Tertiary. Ceophysical Monograph 32: 357-375. Reprinted from The Carbon Cycle and Atmospheric $\mathrm{CO}_{2}$ : Natural Variations Archean to
Present

WOLFE, J.A. (1990) - Palacobotanical evidence for a marked temperature increase following the Cretaceous/Tertiary boundary. Nature, 343(6254): 153-156

WOLFE, J.A. (1993) - A method of obtaining climatic parameters from leaf assemblages. U. S. Geological Sirvey Professional Paper, 2040. $71 \mathrm{p}$.

WOLFE, J.A. (1994) - Tertiary climatic changes at middle latitudes of western North America. Palaeogeography, Palaeoclimatology. Palaeoecology, 108(3/4): 195-205

WOLFE, J.A. \& HOPKINS, D.M. (1967) - Climatic changes recorded by Tertiary land floras in northwestern North America. In: Hatai, H. (Editor), Tertiary Correlations and Climatic Changes in the

WYRWOLt Symp. Pacific Sci. Congr.. Llth, Tokyo, Aug.-Sept. 1966, 25: 67-76.

the Last Glacial Maximum: an outline of AGCM simulation rition of southern hemisphere westerlies at Quaternary Science Reviews, 19:881-898

WRIGHT Jr, H.E. (1989) - The anphi-atlantic distribution of the Younger Dryas palcoclimatic oscillation.
Quaternary Science Reviews, 8:295-306. 
Anexo 1

Relação de familias e gêneros observados no herbário ALCB 


\begin{tabular}{|c|c|c|}
\hline Familia & $\begin{array}{l}\text { Gèneros presentes no Brasil (número de espécies presentes na } \\
\text { Bahia t número de espécies nào presentes na Bahia). Total: } \\
\text { número de gêneros na familia e suas espécies }(1+0)\end{array}$ & $\begin{array}{l}\text { Gêneros não } \\
\text { presentes no } \\
\text { Brasil }\end{array}$ \\
\hline Piperaceae & $\begin{array}{l}\text { Ortonia }(2+0) \text { Piper }(15+3), \text { Peperomia }(11+0) \text {, } \\
\text { Pothomorpha }(1+0) \quad \text { Total: } 4(29+7)\end{array}$ & \\
\hline Lacistemaceae & Lacistema $(1+3) \quad$ Total: $1(1+3)$ & \\
\hline Chloranthaceae & Hedyosmum $(1+0) \quad$ Total: $1(1+0)$ & \\
\hline Salicaceae & & Salix (2) \\
\hline Ulmaceae & Celtis $(3+4)$, Trema $(1+0)$ & \\
\hline Moraceae & $\begin{array}{l}\text { Anocapus }(1+0) \text {, Brosimum }(3+1) \text {, Clarisia }(1+1) \text {, } \\
\text { Chlorophoron }(1+0) \text {, Dortenia }(3+1) \text {, Ficus }(16+7) \text {, } \\
\text { Helicostylis }(1+0) \text {, Maquna }(0+1) \text {, Machura }(1+0) \text {, Sorocea } \\
(2+1) \quad \text { Total: } 10(29+12)\end{array}$ & \\
\hline Cecropiaceae & Cecropia $(6+0)$, Pourouma $(4+0) \quad$ Total: $2(10+0)$ & \\
\hline Urticaceae & Fleurya $(1+0)$, Pilea $(3+0)$, Urera $(2+2)$ Total: $3(6+2)$ & $\begin{array}{l}\text { Boehmeria (3), } \\
\text { Urica (1) }\end{array}$ \\
\hline Proteaceae & $\begin{array}{l}\text { Grevillea }(1+0) \text {, Macadamia }(1+0) \text {, Panopsis }(1+0) \text {, } \\
\text { Roupala }(3+1) \quad \text { Total: } 4(6+1)\end{array}$ & \\
\hline Loranthaceae & $\begin{array}{l}\text { Phrygilanthus }(1+0) \text {, Phihirusa }(3+0) \text {, Psithacanthus }(9+0), \\
\text { Struthanthus }(8+0) \text {, Tripadanthus }(1+0) \quad \text { Total } 5(22+0)\end{array}$ & Ligaria (1) \\
\hline Viscaceae & Phoradendron $(22+0) \quad$ Total: $1(22+0)$ & \\
\hline Opiliaceae & Agonandra $(1+0) \quad$ Total: $1(1+0)$ & \\
\hline Santalaceae & Acanthosyris $(1+0) \quad$ Total: $1(1+0)$ & \\
\hline Olacaceae & $\begin{array}{l}\text { Aptandra }(1+0) \text {, Cathedra }(1+0) \text {, Dulacia }(1+0) \text {, Heisteria } \\
(2+0) \text {, Ptychopetalum }(1), \text { Tetrastylidium }(1+1) \text {, Ximenia }(1+ \\
0) \text {, Schoepfia }(2+0) \quad \text { Total: } 8(9+2)\end{array}$ & \\
\hline Balanophoraceae & Langsdorffia $(1+0)$, Laphophyllum $(1+0) \quad$ Total: $2(2+0)$ & \\
\hline Aristolochiaceae & Aristolochia $(8+0)$ & \\
\hline Rafflesiaceae & Pilosiyles (plantas parasitas, não consideradas) & \\
\hline Polygonaceae & $\begin{array}{l}\text { Anigomum }(1+0) \text {, Coccoloba }(27+1) \text {, Polygonum }(7+2) \text {, } \\
\text { Rumex }(1+0), \text { Ruprechica }(2+3) \text {, Tripalis }(1+0) \\
\text { Total: } 6(39+6)\end{array}$ & \\
\hline
\end{tabular}




\begin{tabular}{|c|c|c|}
\hline Chenopodiaceae & Arriplex $(1+0)$, Chenopodium $(4+0) \quad$ Total $2(5+0)$ & \\
\hline Amaranthaceae & 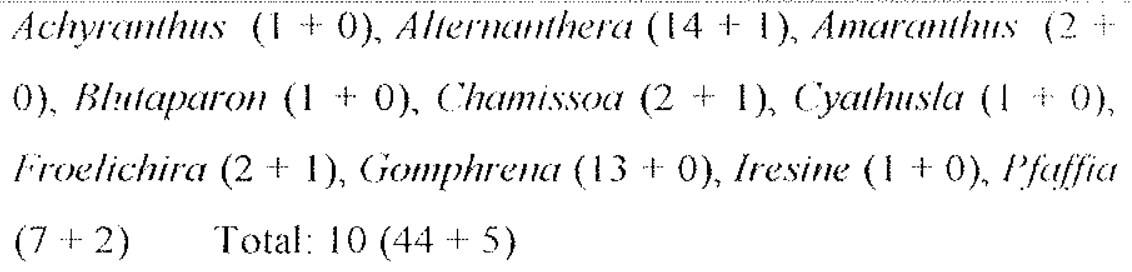 & (elosia (1) \\
\hline Monimiaceae & $\begin{array}{l}\text { Macropeplus }(1+0) \text {, Mollinedia (1), Siparuna }(2+0) \\
\text { Total: } 3(3+1)\end{array}$ & \\
\hline Myristiaceae & $\begin{array}{l}\text { Campsoneura }(1), \text { Myristica }(1+0) \text {, Firola }(5+2) \\
\text { Total: } 3(6+3)\end{array}$ & \\
\hline Annonaceae & $\begin{array}{l}\text { Anxagora }(1+0) \text {, Anonna }(11+5) \text {, Cardiopetalum }(0+1) \text {, } \\
\text { Cymbopetalum }(1+0) \text {, Duguetia }(4+0) \text {, Ephedranthus }(1+0) \text {, } \\
\text { Iusaca }(0+1) \text {, Guatteria }(6+6) \text {, Hornschuchia }(1+0) \text {, } \\
\text { Psendoxandra }(1+1) \text {, Oxandra }(1+0) \text {, Rollimia }(8+3) \text {, } \\
\text { Unonopsis }(1+2) \text {, Xylopia }(7+5) \quad \text { Total: } 14(43+24)\end{array}$ & \\
\hline Connaraceae & Commartis $(4+0)$, Rourea $(5+2) \quad$ Total: $2(9+2)$ & \\
\hline Oxalidaceae & Averthoa $(2+1)$, Oxalis $(11+2) \quad$ Total: $2(13+3)$ & \\
\hline Humiriaceae & $\begin{array}{l}\text { Humiria }(2+1) \text {, Humiriastrum }(1+1) \text {, Saccogeotis }(2+0), \\
\text { Vananea }(3+0) \quad \text { Total: } 4(8+2)\end{array}$ & \\
\hline Linaceae & Limum $(1+0) \quad$ Total: $1(1+0)$ & \\
\hline Tropaeloceae & Trapaeolum $(1+0)$ Total: $1(1+0)$ & \\
\hline Zygophyllaceae & Kallstraemia $(2+1)$, Tribulus $(1+0) \quad$ Total: $2(3+1)$ & $\begin{array}{l}\text { Guatacum (1) } \\
\text { Ianea (2) }\end{array}$ \\
\hline Euphorbiaceae & 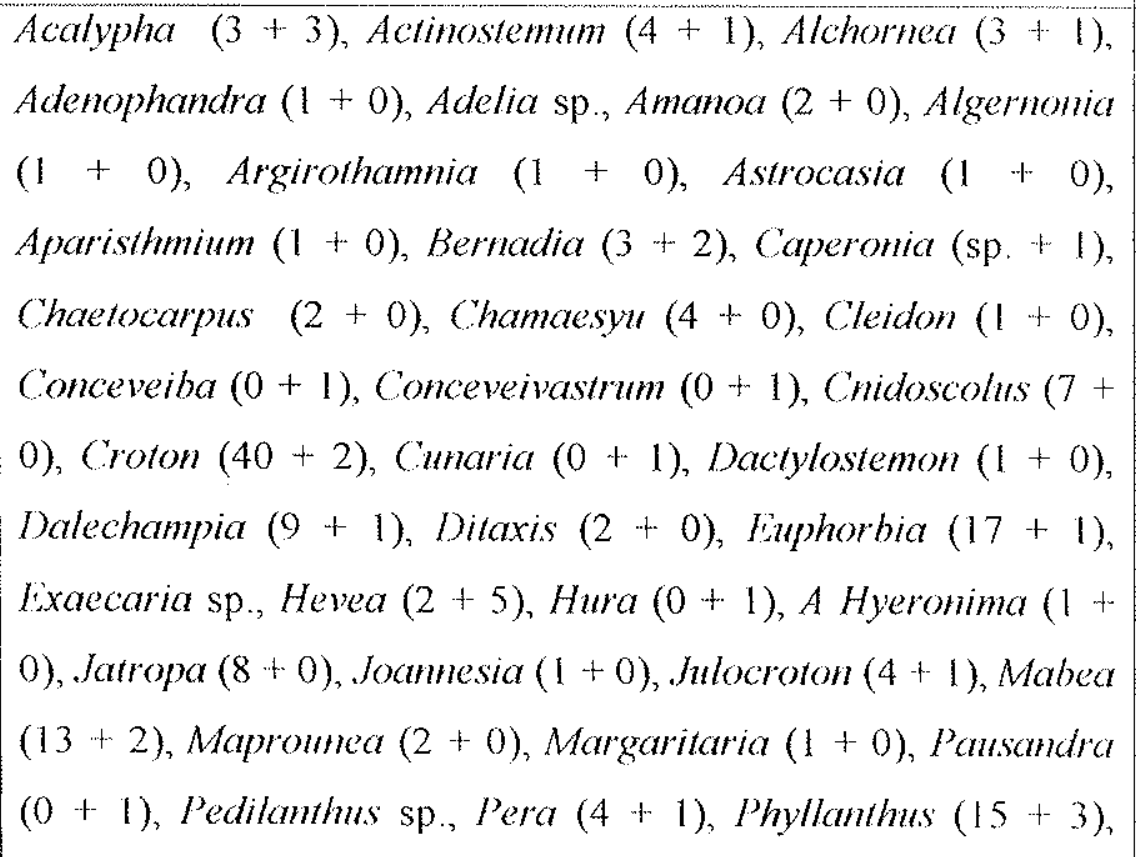 & \\
\hline
\end{tabular}




\begin{tabular}{|c|c|c|}
\hline $\begin{array}{l}\text { Euphobiaceae } \\
\text { (cont.) }\end{array}$ & 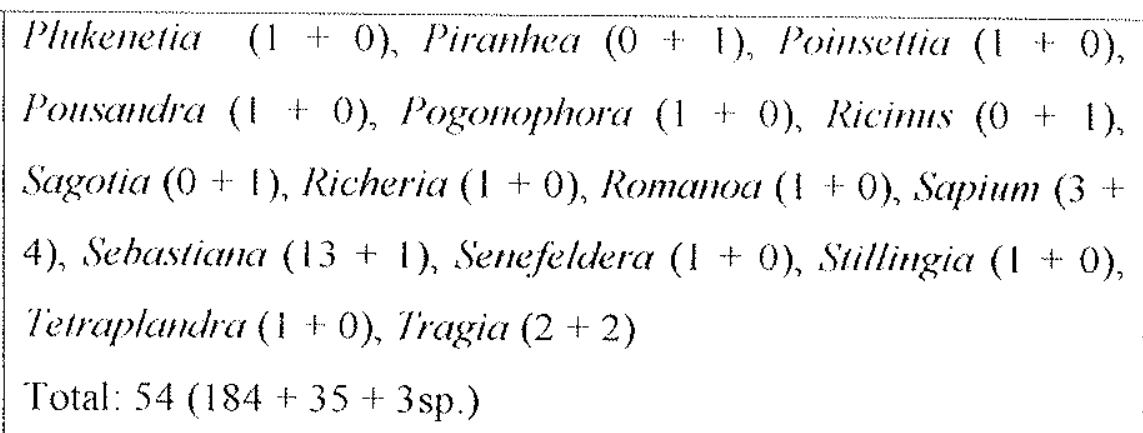 & \\
\hline Trigoniaceate & Lightia $(1+0)$, Trigonia $(7+1) \quad$ Total: $2(8+1)$ & \\
\hline Vochysiaceae & $\begin{array}{l}\text { Lrisma }(1+0), \text { Callistheme }(1+0) \text {, Qualea }(8+2) \text {, Salvertia }(1 \\
+0) \text {,Vochysia }(11+1) \quad \text { Total } 5(22+3)\end{array}$ & \\
\hline Polygalaceae & $\begin{array}{l}\text { Bredemeyera }(9+0) \text {, Dicledanthera }(0+1), \text { Monnima }(2+0) \text {, } \\
\text { Polygala }(33+4) \text {, Securidea }(6+0) \quad \text { Total: } 5(50+5)\end{array}$ & \\
\hline Krameriaceae & Krameria $(3+0) \quad$ Total: $1(3+0)$ & \\
\hline Dichapetalaceae & Stephanopodium $(3+0)$, Tapura $(0+1) \quad$ Total: $2(3+1)$ & \\
\hline Aceraceae & & $A c e(3)$ \\
\hline Sapindaceae & $\begin{array}{l}\text { Allophylus }(4+3) \text {, Averrhoidium }(1+0) \text {, Cardiospermum }(4+ \\
\text { 1), Cupania }(9+2) \text {, Diatenopteryx }(2+0) \text {, Dodonaea }(1+0) \text {, } \\
\text { Gonania sp., Magonia }(2+0) \text {, Matayba }(2+1) \text {, Nephelium }(1+ \\
0) \text {, Paullinia }(9+5) \text {, Pseudina }(0+1) \text {, Sapindus }(2+0) \text {, } \\
\text { Scyphonychium }(1+0) \text {, Serjania }(16+4) \text {, Talisia }(0+1) \text {, } \\
\text { Toulisia }(1+0) \text {, Urvilla }(4+2) \text { Total: } 18(59+20)\end{array}$ & $\begin{array}{l}\text { filicinm } \\
\text { Litche (1) }\end{array}$ \\
\hline Balsaminaceae & Impatiens $(1+0) \quad$ Total: $1(1+0)$ & \\
\hline Rhamnaceae & $\begin{array}{l}\text { Alvimianha }(1+0) \text {, Crumenaria }(1+1), \text { Couania }(4+2) \text {, } \\
\text { Havenia }(0+1) \text {, Reissekia }(3+3) \text {, Zizyphus }(3+1) \\
\text { Total: } 6(12+8)\end{array}$ & \\
\hline Vitaceae & Cissus $(12+1) \quad$ Total: $1(12+1)$ & \\
\hline Elaeocarpaceae & Elaeocarpus $(0+1)$, Sloanea $(6+2) \quad$ Total: $2(6+3)$ & \\
\hline Tiliaceae & $\begin{array}{l}\text { Apeiba }(2+0) \text {, Corchrus }(2+2) \text {, Hidrogaster }(1+0) \text {, Luehea }(5 \\
+1) \text {, Lueheopsis }(0+1) \text {, Mollia }(0+2) \text {, Mustingia }(1+0) \text {, } \\
\text { Triumphetta }(3+0) \text {,Vasivaea }(0+1) \quad \text { Total: } 9(14+7)\end{array}$ & \\
\hline Bombacaceae & $\begin{array}{l}\text { Bombacopsis }(1+0) \text {, Bombax }(2+0) \text {, Caranillesia }(1+0) \text {, } \\
\text { Ceiba }(3+0) \text {, Chorisia }(3+1) \text {, Eriotheca }(3+2) \text {, Ochroma }(1+ \\
0) \text {, Pachira }(1+1) \text {, Pseudobombax }(3+0) \text {, Ouararibea }(1+0) \\
\text { Total: } 10(19+4)\end{array}$ & Dllrio (1) \\
\hline
\end{tabular}




\begin{tabular}{|c|c|c|}
\hline Sterculiaceac & $\begin{array}{l}\text { Ayema }(5+1) \text {, Bytlemeria }(2+4) \text {, cola }(1+1) \text {, Dombeya }(1+ \\
\text { 0), Helicteres }(9+9) \text {, Herrania }(0+1) \text {, Cinazuma }(1+0) \text {, } \\
\text { Melochia }(5+2) \text {, Pterigota }(1+0) \text {, Sterculia }(3+1) \text {, } \\
\text { Theobroma }(0+6) \text {, Waltheria }(9+2) \text { Total: } 12(37+27)\end{array}$ & Firmimia (1) \\
\hline $\begin{array}{l}\text { Clusiaceae } \\
\text { (Guttiferae) }\end{array}$ & $\begin{array}{l}\text { Caraipa }(1+0) \text {, Chrsia }(10+0) \text {, Calophylhm }(1+0) \text {, } \\
\text { Kielmewa }(7+0) \text {, Rheedia }(3+0) \text {, Reggeria }(1+0) \text {, Symphonia } \\
(1+0) \text {, Toromita }(6+0) \text {, Vismia }(5+0) \text { Total: } 9(35+0)\end{array}$ & Mammea (1) \\
\hline Bixaceae & Bixa $(2+0) \quad$ Total: $1(2+0)$ & \\
\hline Cochlospermaceae & Cochlospermum $(2+1)$ & \\
\hline Violaceae & $\begin{array}{l}\text { Amphirrhox }(0+3) \text {, Anchietea }(1+0) \text {, Hybanthus }(5+0) \text {, } \\
\text { Noisettia }(1+0) \text {, Paypayola }(1+0) \text {, Rinorea }(1+1) \\
\text { Total: } 6(9+4)\end{array}$ & $\begin{array}{l}\text { Schweiggeria } \\
\text { (1), Viola (1) }\end{array}$ \\
\hline Flacourtiaceae & $\begin{array}{l}\text { Azara }(0+1) \text {, Banara }(2+0) \text {, Carpotroche }(1+0) \text {, Casearia }(9 \\
+6) \text {, Hamalium }(0+1) \text {, Oncoba }(0+1) \text {, Peridiscus }(1+0) \text {, } \\
\text { Ptychocarpus }(0+1) \text {, Prockia }(2+0) \text {, Xylosma sp. } \\
\text { Total: } 9(13+1 \mathrm{sp}+10)\end{array}$ & $\begin{array}{l}\text { Aphaerema (1), } \\
\text { Flacourtia (1) }\end{array}$ \\
\hline Lecythidaceae & $\begin{array}{l}\text { Carimiana }(1+2) \text {, Couroupita }(1+0) \text {, Couratari }(1+0) \text {, } \\
\text { Eschweileta }(2+0) \text {, Holopyxidium }(1+0) \text {, Lecythis }(3+0) \\
\text { Total: } 6(9+2)\end{array}$ & \\
\hline Rhizophoraceae & Cassipourea $(0+1)$, Rhizophora $(1+0) \quad$ Total: $2(1+1)$ & \\
\hline Dialypetalanthaceae & Dialypetalanthus $(0+1) \quad$ Total: $1(0+1)$ & \\
\hline Combretaceae & $\begin{array}{l}\text { Buchenaria }(1+0) \text {, Combretum }(7+0) \text {, Conocarpus }(1+0) \text {, } \\
\text { Lagunalaria }(1+0) \text {, Terminalia }(8+2) \text {, Thiloa }(1+0) \\
\text { Total: } 6(19+2)\end{array}$ & Onisqualis (1) \\
\hline Memecylaceae & Mouriri $(1+0) \quad$ Total: $1(1+0)$ & \\
\hline Halogaceae & Laurembergia $(1+0)$, Myriophyllum $(1+1) \quad$ Total: $2(2+1)$ & \\
\hline Onagraceae & $\begin{array}{l}\text { Jussiacia }(1+0), \text { Ludwigia }(7+3), \text { Oenothera }(0+1) \text {, } \\
\text { Sanvagesia }(1+0) \quad \text { Total: } 4(9+4)\end{array}$ & Fuchsia (1) \\
\hline Araliaceae & $\begin{array}{l}\text { Dendropanax }(0+1) \text {, Didymopanax }(1+0) \text {, Oreopanax }(1+0) \text {, } \\
\text { Polyscias }(1+0) \text { Scheffera }(5+1) \quad \text { Total: } 5(8+2)\end{array}$ & \\
\hline Apiaceae & $\begin{array}{l}\text { Anethum }(1+0) \text {, Apium }(1+0) \text {, Centella }(1+0) \text {, Eryngium }(7+ \\
\text { 2), Hydrocotyle }(5+0) \text {, Klotzschia }(1+0) \text {, Petroselimum }(1+ \\
\text { 0), Spananthe }(1+0) \quad \text { Total: } 8(18+2)\end{array}$ & $\begin{array}{l}\text { Coriandrum } \\
\text { (1), Dancus (1), } \\
\text { Pimpinella (1) }\end{array}$ \\
\hline
\end{tabular}




\begin{tabular}{|c|c|c|}
\hline Clethraceae & (kethat (1+1) Total: $1(1+1)$ & \\
\hline Ericaceae & $\begin{array}{l}\text { Agrarista }(3+2),(y \text { imms }(1+0), \text { Gallussaciu }(4+2) \\
\text { Total: } 3(8+4)\end{array}$ & $\begin{array}{l}\text { (iatulheria (3), } \\
\text { Rhotodendron } \\
\text { sp., Faccinimm } \\
\text { (1) }\end{array}$ \\
\hline Menispermaceae & $\begin{array}{l}\text { Abuta }(0+2) \text {, (issampelos }(4+0) \text {, Chondrodemelron }(1+0) \text {, } \\
\text { Odoniocaria }(2+1) \quad \text { Total: } 4(7+3)\end{array}$ & \\
\hline Magnoliaceae & Gêneros não identificados. Poucos espécimes. & \\
\hline Winteraceae & Drimys $(2+0) \quad$ Total: $1(2+0)$ & \\
\hline Berberidaceae & Berberis $(0+1) \quad$ Total: $1(0+1)$ & \\
\hline Basellaceae & Basella sp. Total: I (Isp. +0$)$ & \\
\hline Ranunculaceae & Clemalis $(1+2)$, Delphinium $(1+0) \quad$ Total: $2(2+2)$ & Ranauthculus(I) \\
\hline Caryophyllaceae & $\begin{array}{l}\text { Drymaria }(1+0), \text { Paromychia }(1+0) \text {, Polycarpaea }(1+0) \text {, } \\
\text { Saponaria }(0+1) \quad \text { Total: } 4(3+1)\end{array}$ & $\begin{array}{ll}\text { Arenaria } & (1), \\
\text { Cerastium (1), } \\
\text { Silene (1) }\end{array}$ \\
\hline Nymphaeaceae & Nymphaea $(2+0) \quad$ Total: $1(2+0)$ & \\
\hline Cabombaceae & Cabomba $(2+2)$ Total: $1(2+2)$ & \\
\hline Ceratophyllaceae & & Ceratophyllum \\
\hline Portulaceae & Portula $(7+0)$, Talimum $(4+1) \quad$ Total: $2(11+1)$ & Claylomia (1) \\
\hline Aizoaceae & $\begin{array}{l}\text { Gleischrothamus }(1+0) \text {, Mesembryanthlmun }(1+0) \text {, Sesurrium } \\
(1+0) \text {, Trianthema }(1+0) \text { Total } 4(4+0)\end{array}$ & \\
\hline Molluginaceae & Glimus $(1+0)$, Mollugo $(1+0)$ Total $2(2+0)$ & \\
\hline Phytolacaceae & $\begin{array}{l}\text { Gallesia }(2+0) \text {, Hilleria }(1+0) \text {, Microtea }(7+1) \text {, Petiveria }(2 \\
+0) \text {, Phytolacca }(2+0) \text {, Trichastigma }(1+0) \text {, Seguiaria }(2+0) \text {, } \\
\text { Rivina }(1+1) \quad \text { Total: } 8(18+2)\end{array}$ & \\
\hline Nyctaginaceae & $\begin{array}{l}\text { Amaioura }(1+0) \text {, Boerhania }(6+0) \text {, Guapira }(6+1) \text {, Miriabilis } \\
(1+0) \text {, Nea }(1+0) \text {, Pisonia }(2+1) \text {, Ramisia }(1+0) \\
\text { Total: } 7(18+2)\end{array}$ & \\
\hline Lauraceae & $\begin{array}{l}\text { Aioutea }(1+0) \text {, Anechithaturea sp., Aniba }(1+0) \text {, Cassytha }(3+ \\
0) \text {, Cinnamomum }(2+2) \text {, Cryptocaria }(1+0) \text {, Licania }(1+0) \text {, } \\
\text { Nectandra }(3+10), \text { Ocotea }(23+9) \text {, Persea }(31+0) \\
\text { Total: } 10(38+21)\end{array}$ & $\begin{array}{l}\text { Acrodicledium } \\
\text { (1), Ajowea (1), } \\
\text { Clinoslemom } \\
\text { (1), Endlicheria } \\
\text { (1), Laurus (1), }\end{array}$ \\
\hline
\end{tabular}




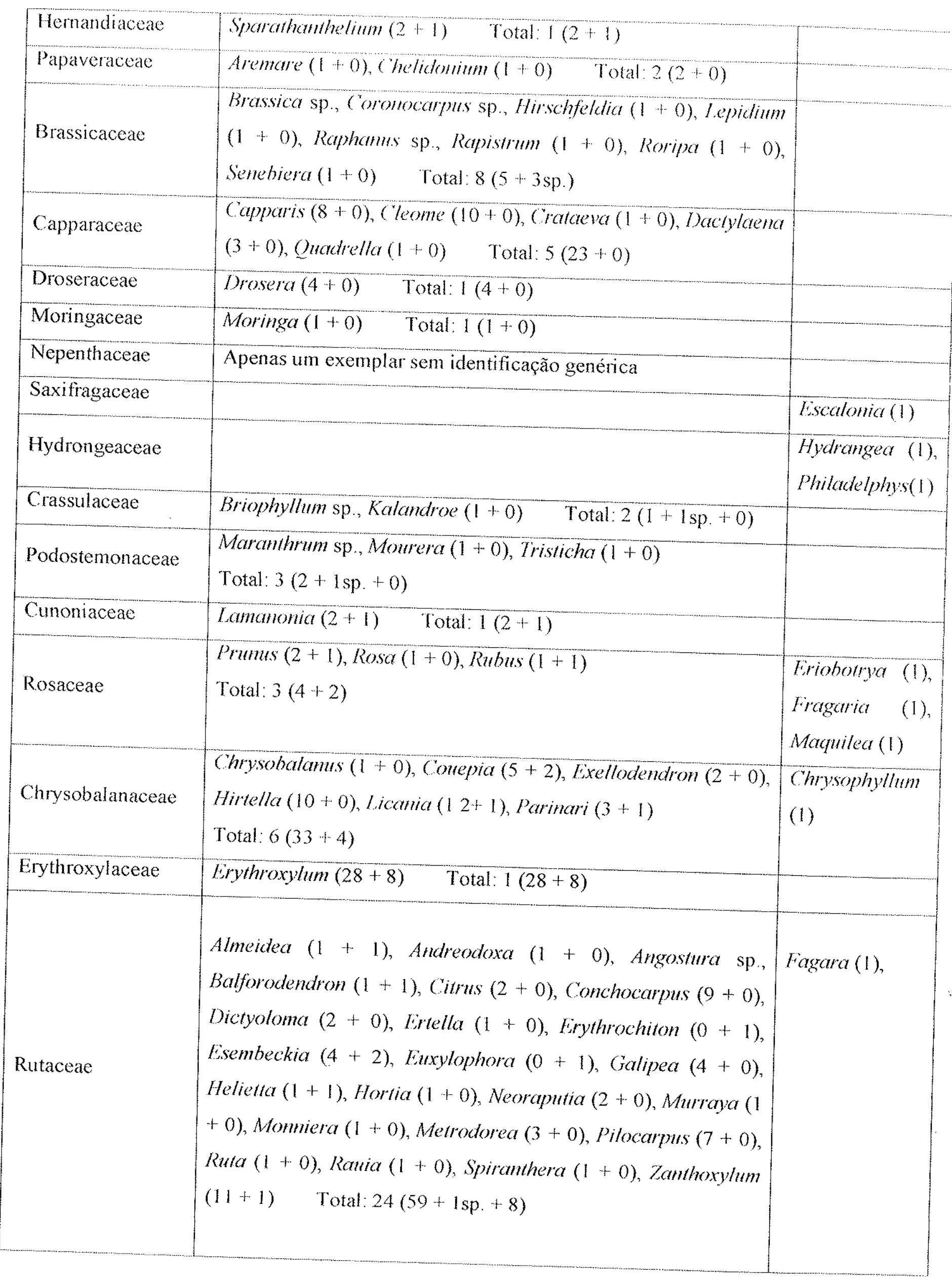




\begin{tabular}{|c|c|c|}
\hline Simaroubaceae & $\begin{array}{l}\text { Marupa sp., Pricanmia }(3+1) \text {, Simaba }(3+1) \text {, Simaromba }(2+0) \\
\text { Total: } 4(8+1 \mathrm{sp} .+2)\end{array}$ & \\
\hline Burseraceac & $\begin{array}{l}\text { Bursera sp., Cammiphora }(1+0) \text {, Protium }(6+1) \\
\text { Total: } 3(7+1 \mathrm{sp} .+1)\end{array}$ & \\
\hline Meliaceac & $\begin{array}{l}\text { Cabralea }(1+0) \text {, Canjirana sp., Carapa }(1+0), \text { Cedrella }(1+ \\
\text { 1), Cuarea }(2+1) \text {, Trichilia }(8+5) \quad \text { Total: } 6(13+1 \mathrm{sp}+8)\end{array}$ & Melia (1) \\
\hline Malpighiaceae & $\begin{array}{l}\text { Aspicarpa }(1+0) \text {, Bamisteropsis }(17+3) \text {, Brachypteris }(1+0) \text {, } \\
\text { Bunchosia }(0+1) \text {, Byrsonima }(23+5) \text {, Callacum }(1+0) \text {, } \\
\text { Camarea }(2+1) \text {, Clonodia sp., Dicella }(2+1) \text {, Galphimia }(1+ \\
0) \text {, Heteropterys }(18+3) \text {, Malpighia }(2+0) \text {, Mascagnia }(4+1) \text {, } \\
\text { Peixotoa }(3+2) \text {, Ptilochaeta }(2+0), \text { Schwania }(0+1) \text {, } \\
\text { Stigmaphyllon }(7+3) \text {, Tetrapterys }(8+2) \text {, Thryallis }(2+0) \\
\text { Total: } 19(95+1 \mathrm{sp}+23)\end{array}$ & $\begin{array}{l}\text { Vermuncularia } \\
\text { (1) }\end{array}$ \\
\hline Buxaceae & Simondsia $(1+0) \quad$ Total: $1(1+0)$ & \\
\hline Anacardiaceae & 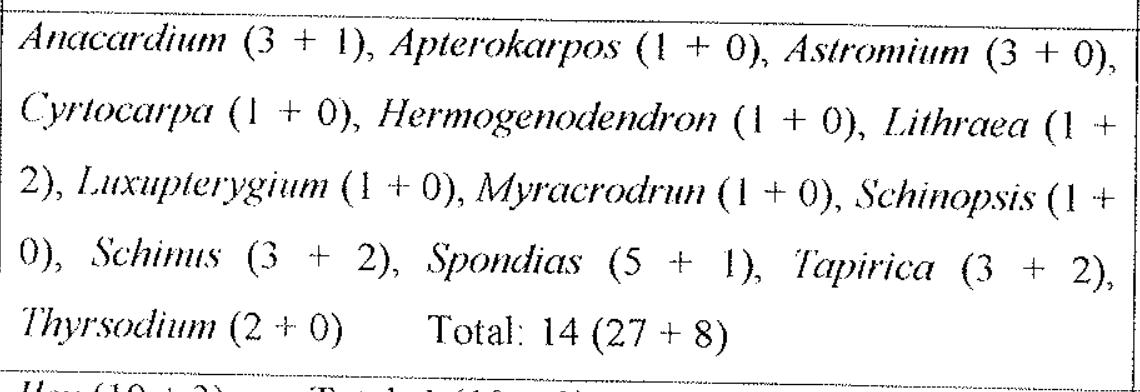 & Mangifera (1) \\
\hline Aquifoliaceae & Ilex $(10+3) \quad$ Total: $1(10+3)$ & \\
\hline Celastraceae & $\begin{array}{l}\text { Austroplenckia }(1+0) \text {, Frannhofera }(1+0), \text { Goupia }(0+1) \text {, } \\
\text { Maylems }(6+2), \text { Plenckia }(1+0) \quad \text { Total: } 5(9+1)\end{array}$ & Euonymus (1) \\
\hline Hippocrataceae & $\begin{array}{l}\text { Cheiloclinium }(2+0) \text {, Hyppocratea }(2+1) \text {, Humirianthera }(0+ \\
\text { 1), Peritassa }(0+3) \text {, Pristimera }(1+1) \text {, Salaria sp., Tontella }(0 \\
+1) \quad \text { Total: } 7(5+1 \mathrm{sp} .+7)\end{array}$ & \\
\hline Icacinaceae & $\begin{array}{l}\text { Dendonbrangia }(0+1) \text {, Discophora }(1+1) \text {, Emmotum }(3+0) \\
\text { Total: } 3(4+2)\end{array}$ & \\
\hline Malvaceae & $\begin{array}{l}\text { Abutilon }(2+2) \text {, Bakeridesia }(0+1) \text {, Bastardia }(1+0) \text {, } \\
\text { Bogenhardia sp., Cienfuegosia }(0+1) \text {, Gaya }(2+0) \text {, } \\
\text { Grossypium }(1+0) \text {, Herissantha }(2+1) \text {, Hibiscus }(7+0) \text {, } \\
\text { Malachra }(2+0) \text {, Malvastrum }(2+1) \text {, Pavonia }(20+3) \text {, } \\
\text { Pseudoabutilon }(1+0) \text {, Pseudomalachra }(1+0) \text {, Peltaea }(4+ \\
\text { 1), Sida }(24+3) \text {, Sidastrum }(2+0) \text {, Triplochlamys }(1+0) \text {, } \\
\text { Urena }(1+0) \text {, Wissadula }(6+2) \quad \text { Total: } 20(98+1 \mathrm{sp}+15)\end{array}$ & $\begin{array}{l}\text { Krapovickasia } \\
\text { (1) } \\
\text { Malvaviscus (2) } \\
\text { Thespesia (2) }\end{array}$ \\
\hline
\end{tabular}




\begin{tabular}{|c|c|c|}
\hline Surianaceae & Suriana $(1+0)$ & \\
\hline Dilleniaceac & $\begin{array}{l}\text { Curatalla }(1+0), \text { Davilla }(7+0) \text {, Doliocarpus }(3+0) \\
\text { Tetracera }(3+0) \quad \text { Total: } 4(14+0)\end{array}$ & \\
\hline Ochnaceae & $\begin{array}{l}\text { Luxemburgia }(1+1) \text {, Ouratea }(7+5) \text {, Samagresia }(1+0) \\
\text { Total } 3(11+7)\end{array}$ & \\
\hline Caryocaraceae & Anhodiscus $(0+1)$, caryocar $(4+0) \quad$ Total: $2(4+1)$ & \\
\hline Marcgraviaceae & $\begin{array}{l}\text { Marcgravia }(1+0) \text {, Noranthea }(1+1) \text {, Somroubea }(1+0) \\
\text { Total: } 3(3+1)\end{array}$ & \\
\hline Quinaceae & $\begin{array}{l}\text { Lacunaria }(0+2) \text {, Ouina }(0+8) \text {, Touroulia }(0+1) \\
\text { Total: } 3(0+11)\end{array}$ & \\
\hline Bonnetiaceae & Bonnetia $(1+0) \quad$ Total: $1(1+0)$ & \\
\hline Theaceae & $\begin{array}{l}\text { Camellia }(0+1), \text { Gordonia }(1+0) \text {, Ternstroemia }(3+1) \\
\text { Total: } 3(4+2)\end{array}$ & \\
\hline Turneraceae & Piriqueta $(9+0)$, Turnera $(18+2) \quad$ Total: $2(27+2)$ & \\
\hline Passifloraceae & Passiflora $(21+6)$, Tetrastylis $(1+0) \quad$ Total: $2(22+6)$ & \\
\hline Cariaceae & Carica $(1+0)$, Jacaratia $(1+0) \quad$ Total: $2(2+0)$ & \\
\hline Loasaceae & Loasa $(1+0)$, Mentzelia $(2+0) \quad$ Total: $2(3+0)$ & Cajophora (1) \\
\hline Begoniaceae & Begonia $(9+5) \quad$ Total: $1(9+5)$ & \\
\hline Thimclaceae & Daphnopsis $(1+1) \quad$ Total $1(1+1)$ & \\
\hline Lythraceae & $\begin{array}{l}\text { Ammania }(1+0) \text {, Corythophora }(0+1) \text {, Crenea }(1+0) \text {, Cuphea } \\
(19+3) \text {, Diplusodon }(4+3) \text {, Heimia }(0+1) \text {, Lofoensia }(2+1) \text {, } \\
\text { Lagestroemiat }(2+0) \text {, Lawsonia }(1+0) \text {, Plemophora }(1+0) \text {, } \\
\text { Rotala sp. Total: } 11(31+1 \mathrm{sp}+9)\end{array}$ & \\
\hline Punicaceae & Punica $(1+0) \quad$ Total: $2(1+0)$ & \\
\hline Theophrastaceae & Clavija $(2+1)$, Jacquinia $(0+1) \quad$ Total: $2(2+2)$ & \\
\hline Primulaceae & Anagallis sp. $\quad$ Total: $1(1 \mathrm{sp} .+0)$ & \\
\hline Plumbaginaceae & Plumbago $(4+0) \quad$ Total: $1(4+0)$ & \\
\hline Sapotaceae & $\begin{array}{l}\text { Achras }(1+0) \text {, Chrysophyllum }(4+2) \text {, Manilkara }(5+2) \text {, } \\
\text { Micropholis }(6+0) \text {, Ponteria }(14+1) \text {, Pradosia }(2+0) \text {, } \\
\text { Sideroxylon }(2+0) \quad \text { Total: } 7(34+5)\end{array}$ & \\
\hline Ebenaceae & Diospyros $(6+1) \quad$ Total: $1(6+1)$ & \\
\hline Styracaceae & Styrax $(3+1) \quad$ Total: $1(3+1)$ & \\
\hline Symplocaceae & Symplocos $(2+7) \quad$ Total: $1(2+7)$ & \\
\hline
\end{tabular}




\begin{tabular}{|c|c|c|}
\hline Loganiaceae & $\begin{array}{l}\text { Amlonia }(1+0) \text {, Buddleja }(0+3) \text {, Spigelia }(6+3) \text {, Surchmms }(6) \\
+9) \text { Total: } 4(13+6)\end{array}$ & \\
\hline Gentianaceae & 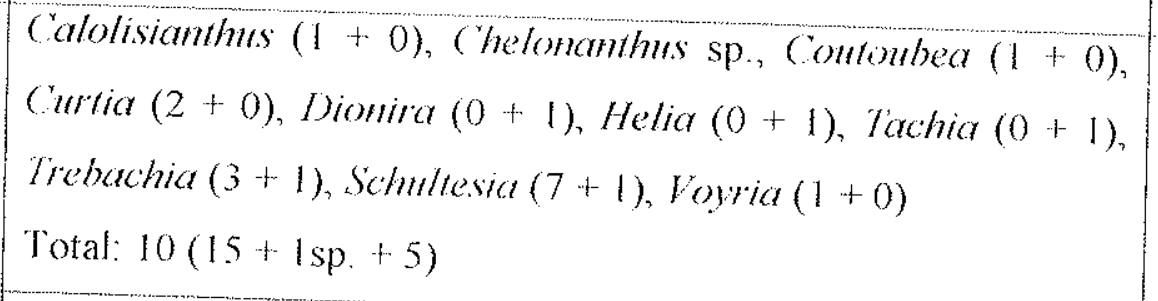 & \\
\hline Asclepiadaceae & 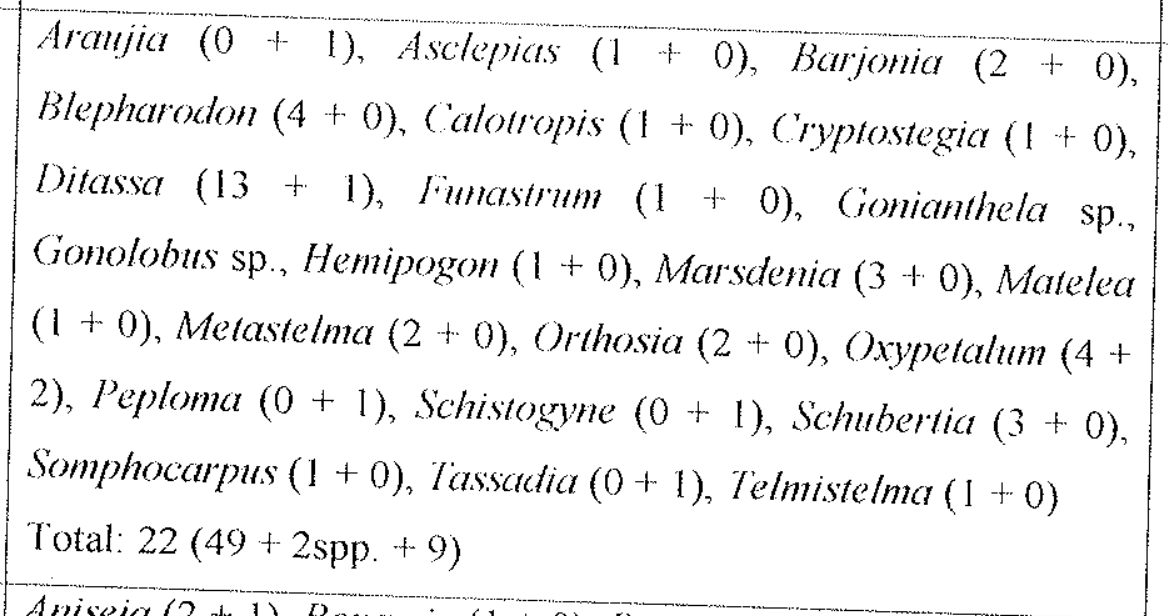 & Stephonotis (1) \\
\hline Convolvulaceae & $\begin{array}{l}\text { Aniseia }(2+1) \text {, Bonamia }(1+0) \text {, Breweria }(1+0) \text {, Cuscuta sp. } \\
\text { Evolvulus }(19+0) \text {, Ipomoea }(22+6) \text {, Jacquemontia }(12+0) \text {, } \\
\text { Maripa }(1+0) \text {, Merremia }(7+1) \text {, Odonellia }(1+0) \text {, Operculina } \\
(1+0), \text { Quamoclit }(1+0) \text {, Turbina }(0+1) \\
\text { Total: } 13(68+1 \mathrm{sp}+9)\end{array}$ & \\
\hline Lamiaceae & $\begin{array}{l}\text { Acollanthus }(1+0) \text {, Liriope }(17+1) \text {, Hypenia }(3+2), \\
\text { Hyptidendron }(0+2) \text {, Hyptis }(37+15) \text {, Leomirus }(2+0), \\
\text { Leonotis }(1+0) \text {, Memha }(0+4) \text {, Marsypianthus }(1+0), \\
\text { Ocimum }(3+3) \text {, Plectranthus }(1+2) \text {, Rhaphiodon }(1+0), \\
\text { Scutellaria }(1+1) \text {, Solenostemon }(2+0) \text {, Stachys }(0+1) \\
\text { Total: } 15(71+31)\end{array}$ & $\begin{array}{l}\text { Lycopus (1), } \\
\text { Pogostemon (1) } \\
\text { Peltodon (1), } \\
\text { Rosmarines (1), } \\
\text { Satvia (3), } \\
\text { Teucrium (1) }\end{array}$ \\
\hline Solanaceae & 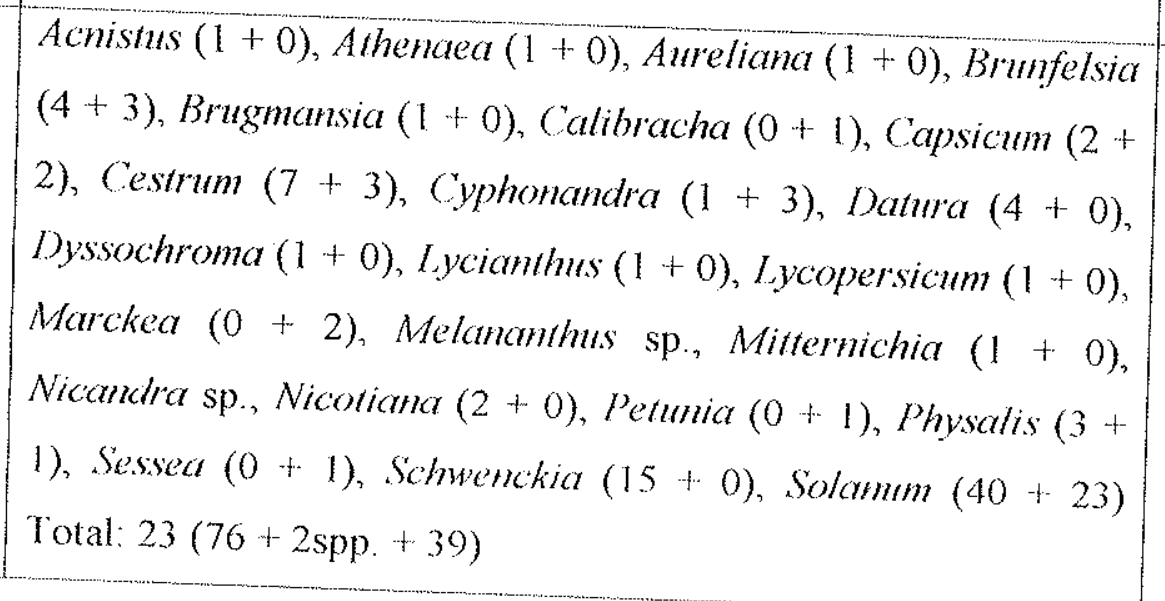 & $\begin{array}{l}\text { Salpichroa (1), } \\
\text { Nierembergia } \\
\text { (2) }\end{array}$ \\
\hline
\end{tabular}




\begin{tabular}{|c|c|c|}
\hline Oleaceae & I.imeciera $(1+0)$, Jasmimum $(1+0)$ Total: $2(2+0)$ & \\
\hline Myrsinaceae & $\begin{array}{l}\text { Apania sp. (ybianthus }(5+0) \text {, Myrsine }(7+3) \text {, Rapanea }(3+0) \\
\text { Total: } 4(15+1 \mathrm{sp}+3)\end{array}$ & \\
\hline Apocynaceae & 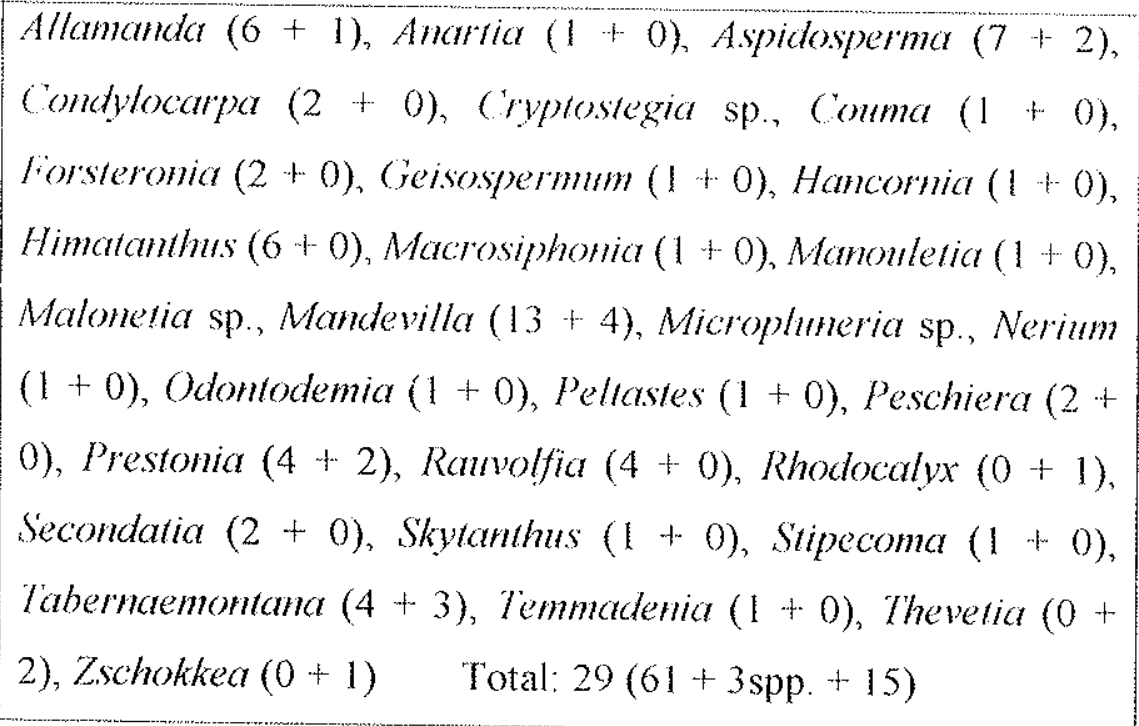 & $\begin{array}{l}\text { Castilloa (1), } \\
\text { Cathoranthus } \\
\text { (1), } \\
\text { Rhabdadenia } \\
\text { (1) }\end{array}$ \\
\hline Cuscutaceae & Cuscuta $(1+0) \quad$ Total: $1(1+0)$ & \\
\hline Menyanthaceae & Nymphoides $(2+0) \quad$ Total: $1(2+0)$ & \\
\hline Hydrophyllaceae & Hydrolea $(1+0) \quad$ Total: $1(1+0)$ & \\
\hline Boraginaceae & $\begin{array}{l}\text { Auxemma }(2+0) \text {, Borrago }(0+1) \text {, Cordia }(28+2) \text {, } \\
\text { Heliotrophium }(8+2) \text {, Pataganula }(1+0) \text {, Tournefortia }(6+1) \\
\text { Total: } 6(45+6)\end{array}$ & \\
\hline Avicenniaceae & Avicennia $(2+1) \quad$ Total: $1(2+1)$ & \\
\hline Verbenaceae & $\begin{array}{l}\text { Aegiphila }(12+1) \text {, Aloysia }(1+3) \text {, Amasonia }(1+0) \text {, Bouchea } \\
(1+2) \text {, Citharexylon }(0+3) \text {, Clerodendron }(0+3) \text {, Congea }(1+ \\
0) \text {, Duranta }(2+0) \text {, Gmeliana }(1+0) \text {, Lantana }(19+1) \text {, Lippia } \\
(21+8) \text {, Phyla }(1+0) \text {, Petrea }(0+1) \text {, Priva }(2+0) \text {, } \\
\text { Stachylarpheta }(23+0) \text {, Tamonea }(2+0) \text {, Verbena }(0+5) \text {, } \\
\text { Vitex }(4+2) \quad \text { Total: } 18(93+29)\end{array}$ & $\begin{array}{l}\text { Glandularia }(2) \\
\text { Junellia }(1)\end{array}$ \\
\hline Scrophulariaceae & $\begin{array}{l}\text { Achetania }(3+0) \text {, Anamaria }(1+0) \text {, Angelonia }(11+0) \text {, } \\
\text { Bacopa }(2+0) \text {, Buchneria }(3+0) \text {, Capraria }(1+0) \text {, } \\
\text { Cymbelaria }(0+1) \text {, Conobea }(1+0) \text {, Digitalis sp., Escobeidia } \\
(0+1) \text {, Esterhazya }(1+1) \text {, Herpetis }(1+0) \text {, Heterantha }(1+0) \text {, } \\
\text { Melasma }(=\text { Alectra })(1+0) \text {, Monopera }(1+0) \text {, Otacanthus }(1+ \\
0) \text {, Physocalix }(2+0) \text {, Russelia }(0+1) \text {, Scoparia }(1+2) \text {, } \\
\text { Stenodia }(4+2), \text { Torenia }(1+0) \text {, Tetraulacium }(1+0) \text {, } \\
\text { Verbascum }(1+0) \quad \text { Total: } 23(38+1 \mathrm{sp}+8)\end{array}$ & \\
\hline
\end{tabular}




\begin{tabular}{|c|c|c|}
\hline Lentibulariaceae & Utricularia $(16+1) \quad$ Total: $1(16+1)$ & \\
\hline Gesteriaceae & $\begin{array}{l}\text { Besleria }(1+0) \text {, Codonamtha }(2+0) \text {, Cubitamthus }(1+0) \text {, } \\
\text { Drymonia }(1+0) \text {, Episcia }(1+0) \text {, Ciloxinia }(0+1) \text {, } \\
\text { Nematamlhus }(0+1) \text {, Paliavana }(1+0) \text {, Simmingia }(4+3) \\
\text { Total } 9(11+5)\end{array}$ & \\
\hline Bignoniaceae & 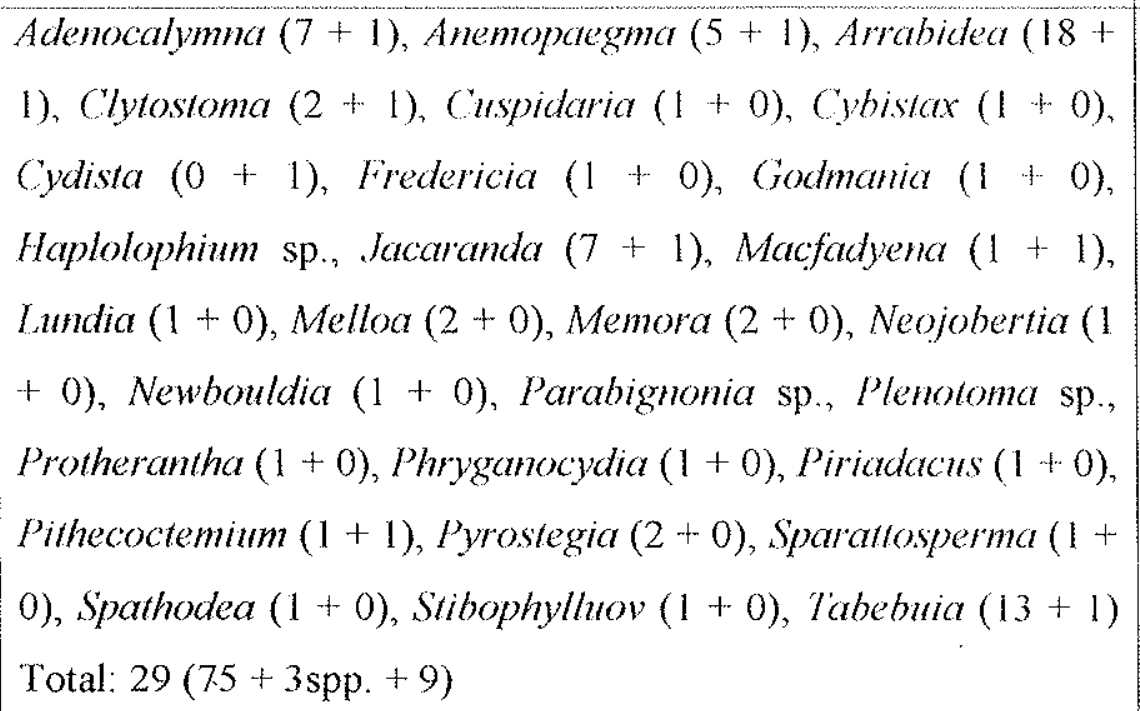 & Podramea $(1)$ \\
\hline Pedaliaceae & Craniolaria sp., Sesamum $(1+0) \quad$ Total: $1(1+1 \mathrm{sp} .+0)$ & Ibecella (1) \\
\hline Mendoniaceae & Mendoncia $(1+1) \quad$ Total: $1(1+1)$ & \\
\hline Plantaginaceae & Plantago $(1+0)$ Total: $1(1+0)$ & \\
\hline Acanthaceae & $\begin{array}{l}\text { Amasonia }(1+0) \text {, Anisocanthus }(1+0) \text {, Aphelandra }(6+1) \text {, } \\
\text { Dichiptera }(1+0) \text {, Elytracia }(1+0) \text {, Eranthemum }(1+1) \text {, } \\
\text { Geissomeria }(2+0) \text {, Harpochiles }(3+0) \text {, Herpetacamihus }(1+ \\
0) \text {, Hygrophila }(2+1) \text {, Jacobina }(0+1) \text {, Justicia }(12+3) \text {, } \\
\text { Lepidogathis }(2+1) \text {, Lophotecium }(1+0) \text {, Mondoncia sp., } \\
\text { Nelsonia sp., Pachystachys }(1+0) \text {, Poikilacanthus }(4+1) \text {, } \\
\text { Ruellia }(10+2) \text {, Sanchegia }(2+1) \text {, Schaueria }(1+0) \text {, } \\
\text { Thumbergia }(2+1) \quad \text { Total: } 21(54+1 \mathrm{sp}+13)\end{array}$ & \\
\hline Caprifoliaceae & Linicera $(0+1)$, Sambucus $(1+2) . \quad$ Total: $2(1+3)$ & $\begin{array}{l}\text { Lonicena sp., } \\
\text { Viburmum (1) }\end{array}$ \\
\hline Valerianaceae & Valeriana $(1+0)$, Valerranopsis sp. $\quad$ Total: $2(1+1 \mathrm{sp} .+0)$ & \\
\hline Campanulaceae & $\begin{array}{l}\text { Centropagon }(1+0) \text {, Laurentia }(1+0) \text {, Lobelia }(2+1), \\
\text { Siphocampylus }(1+2), \text { Wahlenbegia }(0+1) \quad \text { Total: } 5(5+4)\end{array}$ & $\begin{array}{l}\text { Isotoma (1), } \\
\text { Pratia (1), } \\
\text { Specularia (1), } \\
\text { Triodamis (1) }\end{array}$ \\
\hline
\end{tabular}




\begin{tabular}{|c|c|c|}
\hline Cucurbitaceae & 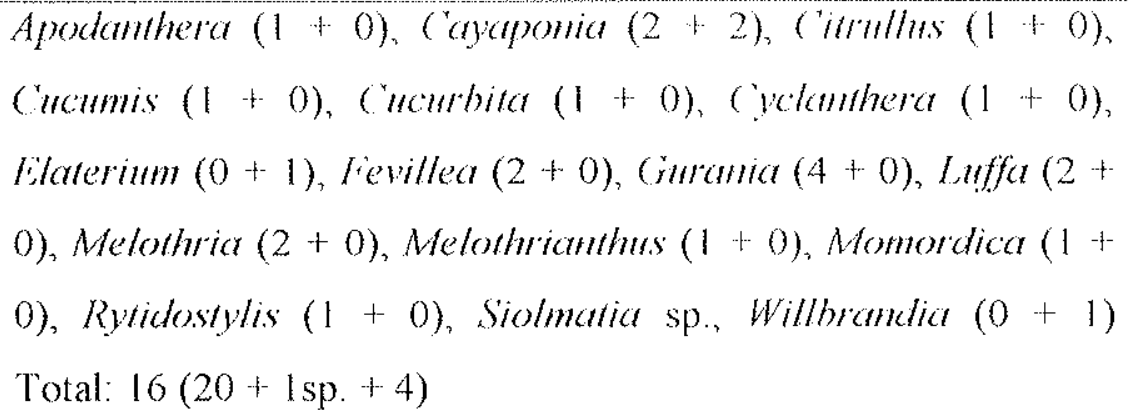 & lagenariasp. \\
\hline Calyceraceae & Acicarpha $(1+1) \quad$ Total: $1(1+1)$ & \\
\hline Goodeniaceae & Scalvola $(0+1) \quad$ Total: $1(0+1)$ & \\
\hline \multicolumn{3}{|l|}{ Rubiaceae } \\
\hline Myrtaceae & $\begin{array}{l}\text { Blepharocalyx }(1+0) \text {, Calycolpus }(1+0) \text {, Calyptrantes }(4+0) \text {, } \\
\text { Camponanesia }(7+5) \text {, Eugenia }(35+15), \text { Comidesia }(7+0) \text {, } \\
\text { Marliera }(6+3) \text {, Myrcengenia }(0+7), \text { Myrcia }(34+14) \text {, } \\
\text { Myrciaria }(4+0) \text {, Pimenta }(0+1) \text {, Plinia }(2+0) \text {, Psidium }(10+ \\
\text { 0), Siphonengenia }(1+0) \text {, Syzyajum }(4+0) \\
\text { Total: } 16(111+45)\end{array}$ & lusia (1) \\
\hline
\end{tabular}

